UNIVERSIDADE DE SÃO PAULO

FACULDADE DE EDUCAÇÃO

\title{
MILTON SCHIVANI
}

ConteXtualizaÇão no Ensino de Física À luZ da TeORIa AnTropológica do DIDÁTICO: O CASO DA ROBÓTICA EDUCACIONAL

SÃo PAULO - SP

2014 



\section{MILTON SCHIVANI}

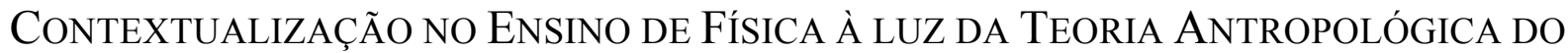
DIDÁTICO: O CASO DA ROBÓTICA EDUCACIONAL

Tese apresentada à Faculdade de Educação da Universidade de São Paulo para a obtenção do título de Doutor em Educação. Versão corrigida e definitiva. A versão original se encontra disponível na Biblioteca da Unidade.

Área de Concentração: Ensino de Física

Orientador: Prof. Dr. Maurício Pietrocola 
AUTORIZO A REPRODUÇÃO E DIVULGAÇÃO TOTAL OU PARCIAL DESTE TRABALHO, POR QUALQUER MEIO CONVENCIONAL OU ELETRÔNICO, PARA FINS DE ESTUDO E PESQUISA, DESDE QUE CITADA A FONTE.

Catalogação na Publicação

Serviço de Biblioteca e Documentação

Faculdade de Educação da Universidade de São Paulo

$371.12 \quad$ Schivani, Milton

S337p Contextualização no Ensino de Física à luz da Teoria Antropológica do Didático: o caso da robótica educacional / Milton Schivani; orientação Maurício Pietrocola. São Paulo: s.n., 2014.

$220 \mathrm{p}$.

Tese (Doutorado - Programa de Pós-Graduação em Educação. Área de Concentração: Ensino de Ciências e Matemática) - - Faculdade de Educação da Universidade de São Paulo.

1. Contextualização 2. Ensino de Física 3. Robótica Educacional 4. Teoria Antropológica do Didático (TAD) 6. Verossimilhança Praxeológica (VP) I. Pietrocola, Maurício, orient. 
Milton Schivani

Contextualização no Ensino de Física à luz da Teoria Antropológica do Didático:

O caso da robótica educacional.

Tese de Doutorado apresentada à Faculdade de Educação da Universidade de São Paulo para obtenção do título de Doutor em Educação.

Área de Concentração: Ensino de Ciências e Matemática

Aprovado em 10 de outubro de 2014.

\section{Banca Examinadora}

\section{Prof. Dr. Maurício Pietrocola \\ FEUSP \\ (Membro Titular)}
Prof. Dr. Elio Carlos Ricardo
FEUSP
(Membro Titular)
Prof. Dr. Luiz Marcos G. Goncalves DCA/CT/UFRN
(Membro Titular)

\author{
Prof. Dr. João Vilhete V. d'Abreu \\ NIED/UNICAMP \\ (Membro Titular)
}
Profa. Dra. Martha Marandino
FEUSP
(Membro Titular)

\author{
Profa. Dra. Lúcia H. Sasseron \\ FEUSP \\ (Membro Suplente)
}

\author{
Prof. Dr. Marcelo Giordan \\ FEUSP \\ (Membro Suplente)
}

\author{
Prof. Dr. Paulo Correia \\ EACH/USP Leste \\ (Membro Suplente)
}

\footnotetext{
Profa. Dra. Marilena Bittar DMT/CCET/UFMS

(Membro Suplente)
} 

Aos de ontem e de hoje, homens e mulheres que me auxiliaram estar aqui, consciente da minha responsabilidade com os de amanhã. 



\section{AgRADECIMENTOS}

"Perde o soberbo a vista e o ingrato a memória."

Os agradecimentos desta tese são uma continuação direta dos agradecimentos da minha dissertação (mestrado). Alguns ambientes e cenários mudaram, algumas pessoas queridas estão distantes e outras mais próximas, a labuta diária está mais diversificada e a responsabilidade aumentou, porém, em todos os casos, o meu sentimento de gratidão, na sua mais ampla acepção, cresceu como uma exponencial positiva.

Minha família, sólida base em que me apoio e fortaleço, não há palavras para expressar tamanha gratidão. Meu pai, José Demilton Alves, minha mãe, Cidalva Janes Schivani Alves, minha irmã, Juliana M. Schivani Alves, e minha amada esposa, Paula Bezerra, pessoas queridas que com muita paciência, amor e carinho, tem me ajudado a caminhar nesta longa jornada chamada vida e, ao cair ou me deparar com um grande obstáculo, sei que estarão comigo para somar as forças e vencer as maiores dificuldades. Obrigado também à minha prima Patrícia Adna E. Takehisa, pela leitura zelosa e revisão do meu trabalho. Aos meus avós (especialmente Maria Alves), que partiram sem antes ver em vida a conclusão do meu doutorado, fica um obrigado e a doce lembrança das inúmeras horas de brincadeiras e gargalhadas que tivemos em família.

Agradeço de modo muito especial ao amigo, professor e orientador Maurício Pietrocola, que me auxiliou e acompanhou de perto meus trabalhos e esforços desde quando cheguei em São Paulo, em 2007, me orientando com muita competência, seriedade e humildade para a vida. Sou imensamente grato pela confiança em mim depositada ao me incentivar a alçar voos cada vez mais altos e pelas inúmeras orientações "extra-acadêmicas" ao longo desses sete anos de colaboração. Além disso, a essência desta tese deve-se aos seus preciosos conselhos e as suas criativas ideias. Você tem todo meu respeito e admiração, obrigado mesmo!

A Faculdade de Engenharia São Paulo (FESP), da Sociedade Educacional São Paulo (SESP), e a Universidade Estadual de Santa Cruz (UESC), localizada em Ilhéus (BA), 
formam os novos e principais ambientes dessa atual jornada. Neles, fui agraciado com a oportunidade de contato profissional e pessoal com diferentes pessoas, que me ensinaram e ensinam inúmeras coisas e me auxiliam na realização de diferentes atividades acadêmicas e administrativas. Dentre essas pessoas, destaco e agradeço aos seguintes nomes (por ordem alfabética) que tive o prazer de conhecer e conviver na FESP (por ordem alfabética): Alfonso Pappalardo Jr., Alexandre Acacio de Andrade, Alrenice Cunha de Castro (Lena, obrigado por me apresentar ao professor Arruda e à FESP.), Antonio Rodrigues Martins (Martins, obrigado pela confiança!), Carlos Alberto G. Pegollo, Carlos Satoshi Aoki, Cassio Firmo Pastana, Creso Franco Peixoto, Eduardo Silva Lisboa, Elias Rodrigues de Moura, Eliete Satie N. Pastana (e família), Emilio Celso Pastorelo Miranda, Engles Anastácio Finotti, Guilherme Gaspar Silva Dias, Heládio de Castro Winz, Hélvio Fregolente Jr., João Dias de Toledo Arruda Neto (Arruda, obrigado pela enorme generosidade!), José Gabriel F. Simões, José Maria Bonato, José Nagib Miziara Filho, Maria Aparecida Oliveira (e Eliana), Mariangela de A. Góes Jorge (Magel), Massimo Argento, Noboru Minei, Noriyoshi Kakuda, Orlando Monezi Jr., Paulo Takashi Nakayama, Plínio F. S. Rodrigues, Sérgio Shimura, Teodoro M. de Amorim Filho e Waldecyr Pereira da Silva. Lembro também com alegria e gratidão dos funcionários Joãozinho, Damião, Paulo, David, Kazé, Severino e das funcionárias Graça e Mariana.

Já na UESC, agradeço (por ordem alfabética) aos seguintes nomes: Adriano Marcus Stuchi, Alex dos Santos Miranda, Amoniel da Cruz de Matos, Ana Rita Brito da Silva, Anderson William Mol, Antônio Edsom Carvalho Filho, Cinthia Fabiana Nunes Menezes, Danilo de Jesus, Eliane Silva Farias, Elisa Prestes Massena, Fabiane Alexsandra Andrade de Jesus, Fernando Luna, Gabriel Pimenta Castro, George Kouzo Shinomiya (e família), Geraldo Wellington Rocha Fernandes, Graciele Silveira, Ingrid Silva Santos, Jules Batista Soares (e família), Leandro de Oliveira Kerber (e família), Lindomar Coutinho da Silva (e família), Marcelo Bento Pisani, Maristela Castro Nery Maia, Maxwell Roger da Purificação Siqueira (e família, especialmente ao Sid!!!), Reinaldo da Silva Gramacho, Roberto Carlos Felício, Simoni Tormohlen Gehlen (e família), Viviane Briccia do Nascimento e Zolacir Trindade de Oliveira dos Santos.

Ao pessoal do Laboratório de Pesquisa em Ensino de Física (LaPEF), sou imensamente grato pelo apoio e suporte que encontrei nesse grupo, sem o qual teria sido difícil concluir esse trabalho, e por alegrarem meu dia a dia. Considero alguns de seus integrantes como parte de minha família, especialmente pela confiança e força depositados 10 
em mim ao longo desses últimos anos. Alguns nomes são recordados com alegria e gratidão, dentre eles estão (por ordem alfabética): Alexandre Campos, Aline Ribeiro Sabino, Anna Maria P. de Carvalho, Carolina Baia, Daniela Fiorini, Danilo Claro Zanardi, Elio C. Ricardo, Estevan Rouxinol (Estevam e Juliana, valeu pela hospitalidade! Fundamental durante meu exame de qualificação.), Felipe Velasquez, Fabiana Botelho Kneubil, Guilherme Brockington, Ivã Gurgel, Jorge L. Nicolau Jr., Nicolli Bernardo Ferreira, Laís Perini, Lúcia Helena Sasseron, Márcia Aguiar, Maurício Pietrocola, Maxwell Roger Siqueira, Pedro Antônio de S. Neto, Renata C. de Andrade Oliveira, Talita Raquel Romero, Thaís Cyrino de M. Forato.

Muito obrigado aos funcionários da Faculdade de Educação da Universidade de São Paulo (FEUSP), que com muita eficiência e paciência nos auxiliam a resolver os problemas técnicos e a seguir com os procedimentos administrativos dos mais diversos. Especiais agradecimentos ao Sr. Milton, Bruna Pozzi Rufato, Marcelo de Souza Ribeiro, Moisés Beluci da Silva e Rafael Barros de Oliveira.

Agradeço a generosidade dos professores que ministraram as disciplinas, cursos e palestras que acompanhei ao longo do meu doutorado, especialmente por compartilharem seus conhecimentos sempre da melhor maneira possível, dentre eles destaco os seguintes nomes (em ordem alfabética): Agnaldo Arroio, André Machado Rodrigues, Carl Winsløw, Elio Ricardo, Gesche Pospiech, Manoel Oriosvaldo de Moura, Paulo Rogério M. Correia, Silvia L. Frateschi Trivelato e Yves Chevallard (Chevallard, merci pour vos conférences au Brésil et par leurs éclaircissements sur la notion de praxéologie.).

Sou imensamente grato ao Grupo ZOOM Holding, parceira do Grupo LEGO da Dinamarca, por nos apresentar ao universo da robótica educacional. Especiais agradecimentos ao Sr. Marcos Wesley pela doação dos kits de robótica da LEGO Education e fascículos ZOOM para o desenvolvimento desta pesquisa e pela confiança depositada em nosso trabalho. Foi uma honra trabalhar com vocês, especialmente ao lado dos seguintes nomes (em ordem alfabética): Alvaro Luis Cruz, Andrea Pereira, Arnaldo, Arthur Sacek, Cesar Barscevicius, Cliviane Valvezan, Francisco Nunes, Mario Batista, Rafael Munhoz, Sueli Costa e Valeria Sitta.

Aos professores e funcionários da Fundação de Apoio à Faculdade de Educação da Universidade de São Paulo (FAFE-USP), sinceros agradecimentos pela colaboração, parceria e pelo apoio logístico. Especiais agradecimentos aos seguintes nomes: Eduardo Guimarães Barroso, Vanessa de Cássia Minutella, Claudia Alves Nunes, Osmar Antonio Pereira, 
Caroline Castillo Ramos Ribeiro, Maria Aparecida da Silva Oliveira, Ana Cristina de Oliveira, Hilário Pereira Duarte, Josefa Maria Francisco e Ricardo Soares da Silva.

Ao Laboratório de Garagem e a todos os "garagistas", obrigado pelo socorro nos momentos mais difíceis, por toda ajuda no desenvolvimento de programações e hardwares. Especiais agradecimentos ao Marcelo Rodrigues, Peterson Guimarães Luciano e ao Renan Abub, valeu pessoal pela ajuda com o Arduino!

Obrigado Paulo Rogério M. Correia e Martha Marandino pelas preciosas contribuições decorrentes do exame de qualificação. Agradeço também aos professores Elio Ricardo, Luiz Marcos G. Goncalves, João Vilhete V. d'Abreu e a professora Martha (novamente) pela participação na defesa. Suas observações e orientações muito enriqueceram o presente trabalho.

Meus sinceros agradecimentos aos professores, coordenadores e estudantes do Colégio Modelo Luís Eduardo Magalhães que participaram das aplicações das atividades de robótica educacional. Destaco a atenção e dedicação do professor Alberto Castro e da professora Adriana Castro Xavier em atender as solicitações desta pesquisa. A conclusão desta tese devese ao apoio que recebi de vocês, obrigado mesmo!

Não posso deixar de lembrar e agradecer às minhas vizinhas da saudosa Rio Pequeno, Aurilane (e família) e Rosa (e família), ao meu padrinho e à minha madrinha de casamento, Walter e Magnólia, e ao amigo H. Leonel Vieira (especialmente pelas agradáveis e preciosas horas de conversas sobre os mais diversos assuntos de ordem pessoal e espiritual, valeu Leonel!).

Por fim, mas não menos importante, obrigado Armin Van Buuren (Mirage \& A State of Trance), Daft Punk (Tron: Legacy), Linkin Park (Greatest Hits), Loreena McKennitt (The Best of) e Zé Ramalho (20 Anos: Antologia Acústica) que, através de suas obras, me auxiliaram a manter a concentração e o isolamento do mundo exterior, aliviando também os momentos de tensão deste trabalho. 
Durante muito, muito tempo, ninguém disse nada. Com o canto do olho, Phouchg via pela janela o mar de rostos cheios de expectativa na praça.

- Nós vamos ser linchados, não vamos? - sussurrou.

- A pergunta não foi fácil - disse Pensador Profundo, com modéstia.

- Quarenta e dois! - berrou Loonquawl. - É tudo que você tem a nos dizer depois de sete milhões e quinhentos mil anos de trabalho?

- Eu verifiquei cuidadosamente - disse o computador -, e não há dúvida de que a resposta é essa. Para ser franco, acho que o problema é que vocês jamais souberam qual é a pergunta.

- Mas era a Grande Pergunta! A Questão Fundamental da Vida, o Universo e Tudo o Mais - gritou Loonquawl.

- É - disse Pensador Profundo, com um tom de voz de quem tem enorme paciência para aturar pessoas estúpidas -, mas qual é exatamente a pergunta?

Um silêncio de estupefação aos poucos dominou os homens, que olharam para o computador e depois se entreolharam.

- Bem, você sabe, é simplesmente tudo... tudo... - começou Phouchg, vacilante.

- Pois é! - disse Pensador Profundo. - Assim, quando vocês souberem qual é exatamente a pergunta, vocês saberão o que significa a resposta.

- Genial - sussurrou Phouchg, jogando o caderno para o lado e enxugando uma pequena lágrima.

- Está bem, está bem - disse Loonquawl. - Será que dava pra você nos dizer qual é a pergunta?

- A Pergunta Fundamental?

- É!

- Sobre a Vida, o Universo e Tudo o Mais?

- É!

Pensador Profundo pensou um pouco.

- Essa é fogo - disse ele.

"O guia do mochileiro das galáxias."

By Douglas Adams (1952-2001) 

SCHIVANI, Milton. Contextualização no Ensino de Física à luz da Teoria Antropológica do Didático: o caso da robótica educacional. 2014, 220p. Tese (Doutorado) - Faculdade de Educação, Universidade de São Paulo, São Paulo, 2014.

\section{RESUMO}

Um ensino de física contextualizado é fortemente identificado no discurso de professores, educadores e pesquisadores da área, reforçado também pelos próprios documentos oficiais do Ministério da Educação do Brasil. Entretanto, a própria noção de contextualização apresenta diferentes vertentes, algumas das quais têm uma visão simplista e acrítica sobre a contextualização no processo de ensino e aprendizagem. Defendemos, contudo, uma contextualização que passe pela problematização e modelização dos saberes disciplinares, partindo de objetos (abstratos ou concretos) de uma dada realidade ou de uma prática social de referência, permitindo ao indivíduo "revisitar" e perceber o mundo ao seu redor de modo diferenciado, com novas perspectivas e possibilidades de ação. Tal abordagem tende a exigir múltiplas estratégias metodológicas e recursos didático-pedagógicos, dentre os quais destacamos a Robótica Educacional (RE), a qual encontra no ensino de ciências um campo novo de aplicações ainda por ser explorado, seja no cenário nacional seja no internacional. Nossa hipótese é a de que materiais dessa natureza potencializam o desenvolvimento de atividades com problematizações que permeiam uma vasta gama de práticas sociais, possibilitando que a realidade seja percebida e se transforme em objeto de reflexão. Ressaltamos que a RE não se justifica por si só, contar com novos e emergentes recursos oferecidos pelas novas tecnologias não necessariamente implica enriquecimento das aulas, é preciso pensá-las vinculadas às necessidades de formação. Especialmente no ensino de física, é necessário atentar-se ao saber-fazer, práxis, sem se esquecer do discurso lógico que o permeia e auxilia na compreensão desse saber-fazer, o logos. Com foco na Robótica Educacional para fomentar a contextualização, analisamos quatro atividades que fazem uso de kits da Lego no ensino de física. Dessas quatro atividades, duas foram aplicadas para estudantes do primeiro ano do ensino médio em uma escola pública do estado da Bahia, Brasil. Fundamentamos nossa investigação com base na Teoria Antropológica do Didático (TAD), a qual permite modelar o conhecimento por meio de uma Organização Praxeológica (OP) e analisar processos de estudo através dos Momentos Didáticos. Constatamos, dentre outras coisas, que a análise praxeológica gera indicadores que auxiliam numa possível reestruturação e desenvolvimento de sequências didáticas para fomentar o processo de contextualização no ensino de física, tais como os níveis de ressonância, podendo ser interno, um diálogo entre o bloco prático-técnico com o tecnológico-teórico da OP didática, e externo, denominado de Verossimilhança Praxeológica (VP), um diálogo entre a OP didática e a OP de referência. Isso foi feito em termos de tarefas, técnicas, tecnologias e teorias, bem como através da investigação da relação do indivíduo $(\mathrm{X})$ com os objetos $(\mathrm{O})$ contidos em diferentes práticas mas centradas em um mesmo bloco tecnológico-teórico. Assim, esperamos contribuir com soluções e reflexões sobre o desenvolvimento e estruturação de atividades didáticas para melhor contextualizar uma dada realidade na perspectiva que adotamos, além de compreender os limites e possibilidades da robótica nesse cenário educacional.

Palavras-chave: Contextualização. Ensino de Física. Robótica Educacional. Teoria Antropológica do Didático (TAD). Verossimilhança Praxeológica (VP). 
SCHIVANI, Milton. Contextualization in the Teaching of Physics in the light of the Anthropological Theory of Didactics: the case of educational robotics. 2014, 220p. Tese (Doutorado) - Faculdade de Educação, Universidade de São Paulo, São Paulo, 2014.

\begin{abstract}
A physics teaching contextualized is strongly identified in the discourse of teachers, educators and researchers in the area, reinforced also by own official documents of the Ministry of Education of Brazil. However, the very notion of contextualization presents different aspects, some of which have a simplistic and uncritical about the background on the teaching and learning process. We advocate, however, a contextualization that pass by questioning and modeling of disciplinary knowledge's, starting from objects (abstract or concrete) of a given reality or a social practice of reference, allowing the individual "revisit" and perceive the world around them in different ways, with new perspectives and opportunities for action. Such an approach tends to require multiple methodological strategies and didactic resources educational, among which we highlight the Education Robotics (ER), which is in the teaching of science a new field of applications still to be explored, is the scenario national or international. Our hypothesis is that materials of this nature potentiate the development of activities with problematization that permeate a wide range of social practices, enabling the reality is perceived and become object of reflection. We emphasize that the ER does not in itself justify, rely on new and emerging resources offered by new technologies does not necessarily imply in enrichment classes, it is necessary to conceive them linked to the training needs. Especially in the teaching of physics, you need to pay attention to know-how, praxis, not forgetting the logical discourse that permeates and assists in the understanding of this know-how, the logos. With a focus on Education Robotics to promote the contextualization, we analyzed four activities that make use of kits from Lego in physics teaching. Two activities were applied to students of the first year of high school in a public school in the state of Bahia, Brazil. We have considered the research on the basis of Anthropological Theory of Didactic (ATD), which allows you to model the knowledge through a Praxeological Organization (PO) and analyze processes of study through the Didactics Moments. We found, among other things, that the praxeological analysis generates indicators that assist in a possible restructuring and development of didactic sequences to promote the process of contextualization in physics teaching, such as the levels of resonance, which can be internal, a dialog between the block practical-technical with the technologytheoretical of the didactics PO, and external, called Verisimilar Praxeology (VP), a dialog between the didactics and reference PO. This was done in terms of tasks, techniques, technologies and theory, investigating also the relation of the individual $(\mathrm{X})$ with objects $(\mathrm{O})$ contained in different practices, but focusing on a same block technological-theoretical. Thus, we hope to be able to contribute with solutions and reflections on the development and structuring of didactic activities to better contextualize a given reality in the perspective that we have adopted, as well as understand the limits and possibilities of robotics in this educational scenario.
\end{abstract}

Keywords: Contextualization. Physics Teaching. Educational Robotics. Anthropological Theory of Didactics (ATD). Verisimilar Praxeology (VP). 


\section{LISTA DE ILUSTRAÇÕES}

Figura 1 - Processo de contextualização em um cenário de aprendizagem específico.

Figura 2 - Sensores: a) Temperatura e Umidade. b) Movimento. c) Distância. d) Corrente elétrica. e) Reflexão

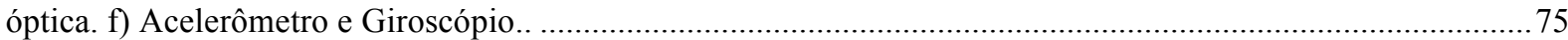

Figura 3 - a) Lego Mindstorms NXT, Kit 9797. b) Arduino, plataforma de prototipagem eletrônica.................76 Figura 4 - Montagens de veículos usando diferentes materiais/ kits. a) Modelix. b) Knex. c) FischerTechnik.

d) Arduino. e) Lego Mindstorms.

Figura 5 - Verossimilhança Praxeológica por interseção....................................................................... 103

Figura 6 - Verossimilhança Praxeológica por correspondência.....................................................................103

Figura 7 - Ponte do rio da cidade de Chicago, EUA. | Richard A. Chapman-Sun-Times.................................104

Figura 8 - Ponte levadiça em construção com kits de robótica educacional (Modelix Robotics)......................104

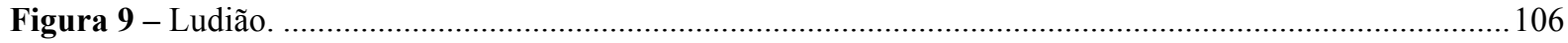

Figura 10 - Capa do fascículo Máquinas e Equilíbrio. ............................................................................120

Figura 11 - HQ ilustrando uma situação hipotética de acidente com empilhadeira. ......................................121

Figura 12 - Transporte de cargas por elevação vertical e horizontal (Atividade "Empilhadeiras"))..................122

Figura 13 - Capa do fascículo Energia e Potência. ................................................................................123

Figura 14 - Choque frontal entre veículos "robô" (Atividade "Colisões")...................................................124

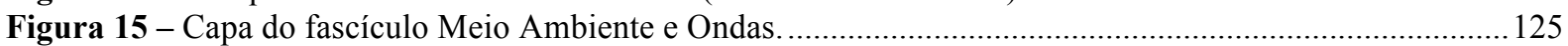

Figura 16 - Montagem proposta para simular e registrar uma onda sísmica. ................................................ 126

Figura 17 - a) Capa do fascículo Armazenamento de Informação e Entretenimento. b) HQ de abertura da

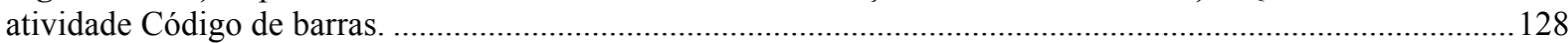

Figura 18 - a) Veículo robô que simula um leitor de código de barras. b) Mapeamento do "labirinto" por onde o

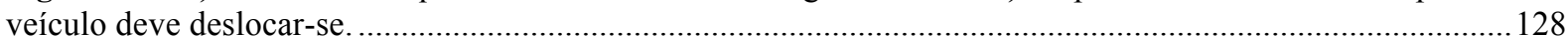

Figura 19 - a) Código de barras que deverá ser confeccionado. b) Código binário de 4 bits para movimento do robô.

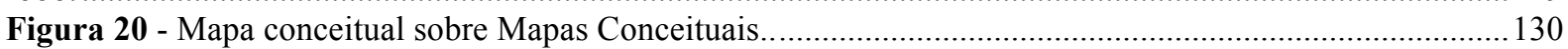

Figura 21 - Interface do Videograph durante a categorização.................................................................. 132

Figura 22 - Exemplo de diagrama gerado pelo Videograph. .................................................................132

Figura 23 - Extrato do fascículo da atividade "Empilhadeiras" em que se identificam dois tipos de tarefa $\left(T_{1}\right.$ e

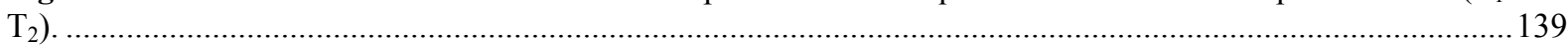

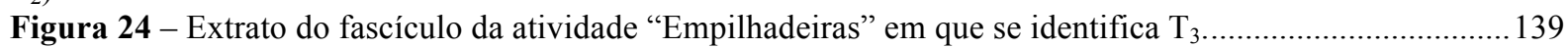

Figura 25 - Extrato do fascículo da atividade "Empilhadeiras" em que se identifica a tarefa t $t_{11} \ldots \ldots \ldots \ldots \ldots \ldots . . . . . . .140$

Figura 26 - Extrato do fascículo da atividade "Empilhadeiras" em que se identifica a tarefa t $t_{42} \ldots \ldots \ldots \ldots \ldots \ldots . . . . . . .140$

Figura 27 - Extrato do fascículo da atividade "Colisões" em que se identificam dois tipos de tarefa, $\mathrm{T}_{1}$ e $\mathrm{T}_{2} .142$

Figura 28 - Extrato do fascículo da atividade "Colisões" em que se identifica o tipo de tarefa $\mathrm{T}_{3} \ldots \ldots \ldots \ldots \ldots \ldots . . . . . . .143$

Figura 29 - Extrato do fascículo da atividade "Colisões”" em que se identifica o tipo de tarefa $\mathrm{T}_{4} \ldots \ldots . . . . . . . . . . . . .143$

Figura 30 - Extrato do fascículo da atividade "Colisões" em que se identifica o tipo de tarefa $\mathrm{T}_{5} \ldots \ldots \ldots \ldots \ldots \ldots . . . . . .143$

Figura 31 - Extrato do fascículo da atividade "Colisões”" em que se identifica o tipo de tarefa $\mathrm{T}_{6} \ldots \ldots \ldots \ldots \ldots \ldots . . . . . . .144$

Figura 32 - Extrato do fascículo da atividade "Sismógrafo" em que se identifica o tipo de tarefa $\mathrm{T}_{1} \ldots \ldots \ldots \ldots . . .146$

Figura 33 - Extrato do fascículo da atividade "Sismógrafo" em que se identificam os tipos de tarefa $\mathrm{T}_{2}$ e $\mathrm{T}_{3} .146$

Figura 34 - Extrato do fascículo da atividade "Sismógrafo" em que se identifica o tipo de tarefa $\mathrm{T}_{4} \ldots \ldots \ldots \ldots . . . .147$

Figura 35 - Extrato do fascículo da atividade "Código de barras" em que se identificam $\mathrm{T}_{1}, \mathrm{~T}_{2}$ e $\mathrm{T}_{3} \ldots \ldots \ldots \ldots . . . .150$

Figura 36 - Mapa conceitual referente aos principais aspectos estruturais e conceituais identificados na OP da prática social de referência - "transporte de cargas via empilhadeiras". ................................................... 155

Figura 37 - Mapa conceitual referente aos principais aspectos estruturais e conceituais identificados na OP

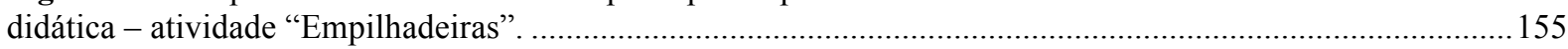

Figura 38 - Mapa conceitual referente aos principais aspectos estruturais e conceituais identificados na OP da prática social de referência - "Colisões em campeonatos de Shok Car". .....................................................158 Figura 39 - Mapa conceitual referente aos principais aspectos estruturais e conceituais identificados na OP

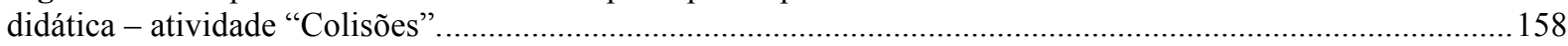

Figura 40 - Mapa conceitual referente aos principais aspectos estruturais e conceituais identificados na OP de

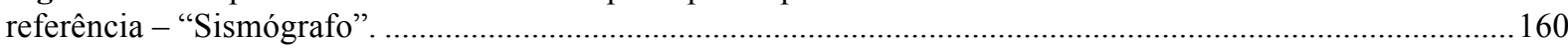
Figura 41 - Mapa conceitual referente aos principais aspectos estruturais e conceituais identificados na OP

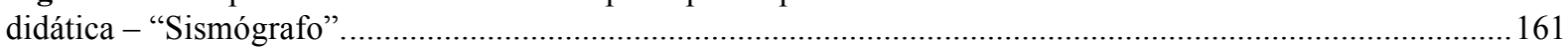

Figura 42 - Mapa conceitual referente aos principais aspectos estruturais e conceituais identificados na OP de

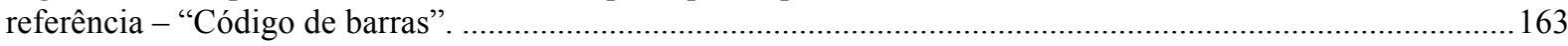


Figura 43 - Mapa conceitual referente aos principais aspectos estruturais e conceituais identificados na OP didática - "Código de barras".

Figura 44 - Análise dos momentos didáticos: atividade "Empilhadeiras" - 10 ano "A", primeira aplicação. ... 167

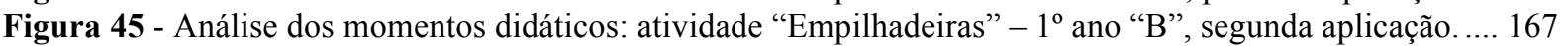

Figura 46 - a) Procedimento inicial apresentado pelo manual de montagem. b) Estudantes selecionando e coletando peças para montagem de acordo com o manual. ..................................................................... 170

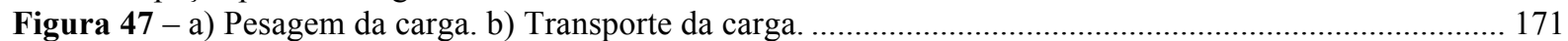

Figura 48 - Pré-montagem da empilhadeira fornecida aos estudantes na segunda aplicação......................... 171

Figura 49 - Questão 4 do pré-teste: atividade "Empilhadeiras".............................................................. 174

Figura 50 - Respostas a questão 4 do pré-teste: atividade "Empilhadeiras". a) Respostas apresentadas por alunos do $1^{\circ}$ ano "A". b) Respostas apresentadas por alunos do $1^{\circ}$ ano "B". c) Percentual das respostas considerando as duas turmas.

Figura 51 - Questão 3 do pós-teste: atividade "Empilhadeiras".

Figura 52 - Respostas a questão 3 do pós-teste: atividade "Empilhadeiras". a) Respostas apresentadas por alunos do $1^{\circ}$ ano "A". b) Respostas apresentadas por alunos do $1^{\circ}$ ano "B". c) Percentual das respostas considerando as duas turmas.

Figura 53 - Pré-montagem de veículo disponibilizado para os estudantes a ser utilizado na atividade "Colisões".

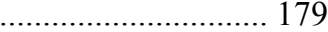

Figura 54 - Análise dos momentos didáticos: atividade "Colisões" ........................................................ 179

Figura 55 - Momento da coleta dos dados experimentais para calcular a velocidade dos veículos. ................ 181

Figura 56 - Respostas apresentadas pelos alunos para a questão 6 do pré-teste: atividade "Colisões"............ 184

Figura 57 - Respostas apresentadas pelos alunos para a questão 1 do pós-teste: atividade "Colisões"............. 185

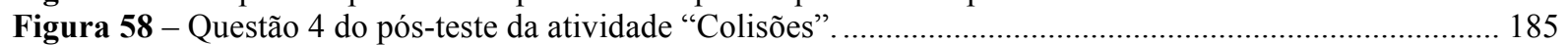

Figura 59 - Respostas apresentadas para a questão 4 do pós-teste da atividade “Colisões"........................... 186

Figura 60 - Lombada eletrônica, comum em grandes centros urbanos........................................................ 188

Figura 61 - Mapa conceitual referente aos principais aspectos estruturais e conceituais identificados na OP da prática social de referência - "Lombada Eletrônica"......

Figura 62 - Sensores que podem ser empregados na montagem da lombada eletrônica na OP didática via o

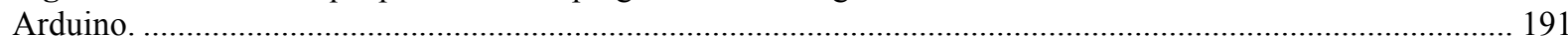

Figura 63 - Esquema da lombada eletrônica com sensor de luz, display de LCD e LEDs. Todas as informações são processadas pelo Arduino. 


\section{LISTA DE TABELAS}

Tabela 1 - Categorias de análise das concepções de contextualização do ensino, contextos de significação e de ocorrência destas concepções.

Tabela 2 - Robôs considerados de "baixo custo". Tabela adaptada de Aroca (2012, p. 33) ...............................78

Tabela 3 - Grade de conteúdos e atividades. Fascículos para o $1^{\circ}$ ano do Ensino Médio.................................118

Tabela 4 - Grade de conteúdos e atividades. Fascículos para o $2^{\circ}$ ano do Ensino Médio. ................................119

Tabela 5 - Categorização dos momentos de estudo usando o software Vídeograph. ........................................134

Tabela 6 - Atividade "Empilhadeiras" em termos de tipos de tarefa e tarefas. ...............................................141

Tabela 7 - Atividade "Empilhadeiras" em termos de técnicas e tecnologias. .................................................141

Tabela 8 - Atividade "colisões" em termos de tipos de tarefa e tarefas...................................................... 144

Tabela 9 - Atividade "colisões" em termos de técnicas e tecnologias.............................................................145

Tabela 10 - Atividade "sismógrafo" em termos de tipos de tarefa e tarefas...................................................147

Tabela 11 - Atividade "sismógrafo" em termos de técnicas e tecnologias. .....................................................148

Tabela 12 - Atividade "código de barras" em termos de tipos de tarefa e tarefas. .......................................150

Tabela 13 - Atividade "código de barras" em termos de técnicas e tecnologias. ..............................................151

Tabela 14 - Tempo total aproximado dedicado para cada momento identificado na aplicação da atividade

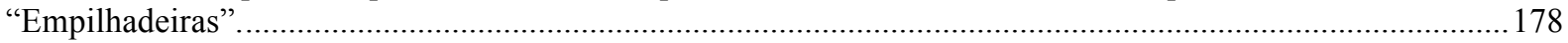

Tabela 15 - Tempo total aproximado dedicado para cada momento identificado na aplicação da atividade

"Colisões". 


\section{LISTA DE ABREVIATURAS}

DCNEM - Diretrizes Curriculares Nacionais do Ensino Médio.

FAI - Física Auto-Instrutiva

FUNBEC - Fundação Brasileira para o Desenvolvimento do Ensino de Ciências.

GREF - Grupo de Reelaboração do Ensino de Física.

IBECC - Instituto Brasileiro de Educação, Ciência e Cultura.

MC - Mapa Conceitual.

MEC - Ministério da Educação do Brasil.

OECD - Organisation for Economic Co-operation and Development.

OP - Organização Praxeológica.

PCNEM - Parâmetros Curriculares Nacionais para o Ensino Médio.

PCN+ - Orientações Educacionais Complementares aos Parâmetros Curriculares Nacionais.

PEF - Projeto de Ensino de Física.

PISA - Programa Internacional de Avaliação de Estudantes.

PSSC - Physical Science Study Committee.

RE - Robótica Educacional

TAD - Teoria Antropológica do Didático.

VP - Verossimilhança Praxeológica. 


\section{LISTA DE SÍMBOLOS}

(T) - Tipo de tarefa.

(t) - Tarefa.

$(\tau)-$ Técnica.

$(\theta)$ - Tecnologia.

$(\Theta)$ - Teoria.

(I) - Instituição.

(X) - Sujeito.

(O) - Objeto. 



\section{SUMÁRIO}

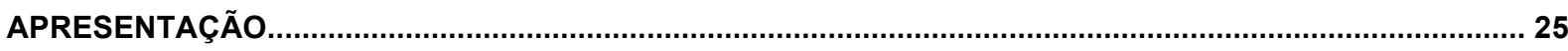

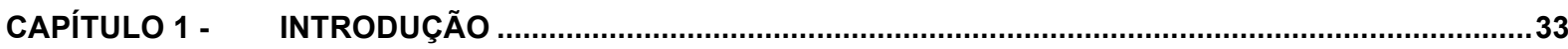

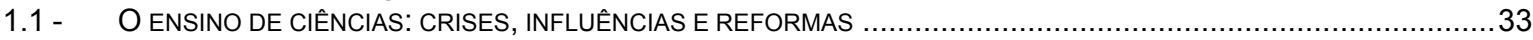

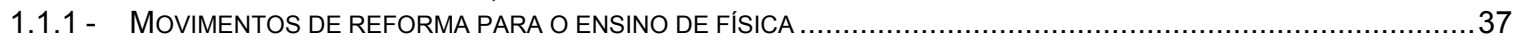

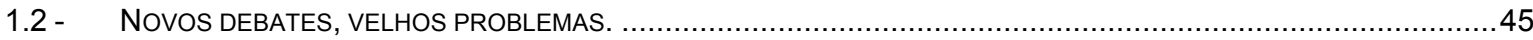

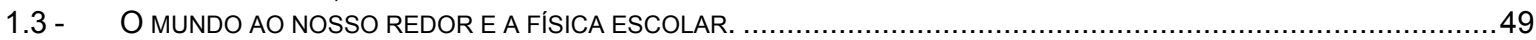

1.4 - PROBLEMATIZAÇÃO E CONTEXTUALIZAÇÃO NO ENSINO DE FÍSICA. .....................................................52

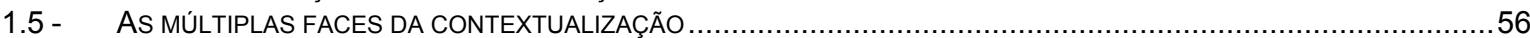

1.5 .1 - NOÇÃO DE CONTEXTUALIZAÇÃO ADOTADO E QUESTÕES INICIAIS DA TESE ..............................................62

CAPÍTULO 2 - RECORTE, QUESTÕES CENTRAIS E OBJETIVOS DA PESQUISA: O CASO DA

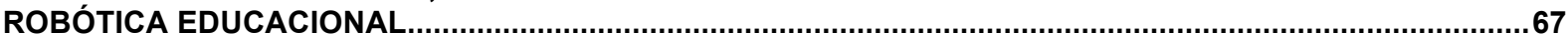

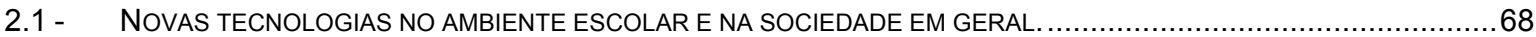

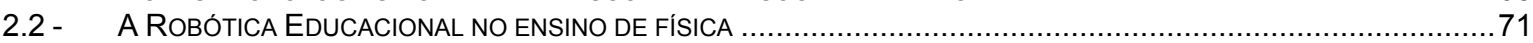

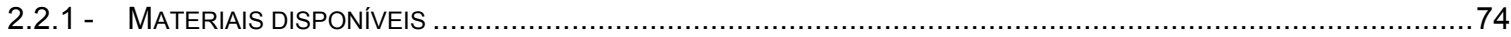

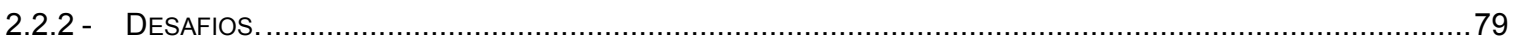

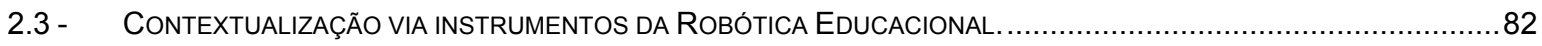

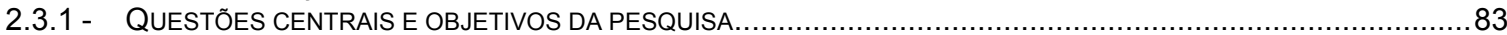

CAPÍTULO 3 - $\quad$ A TEORIA ANTROPOLÓGICA DO DIDÁTICO E A NOÇÃO DE VEROSSIMILHANÇA

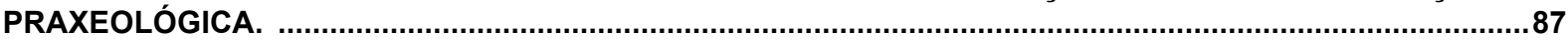

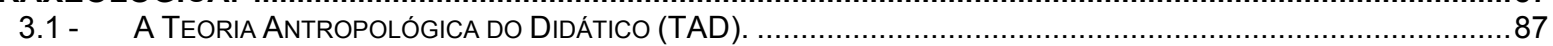

3.2 - $\quad$ A NOÇÃO DE PRAXEOLOGIA E AS ORGANIZAÇÕES PRAXEOLÓGICAS (OP) ..........................................8

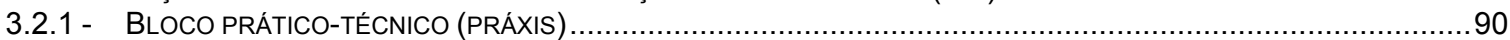

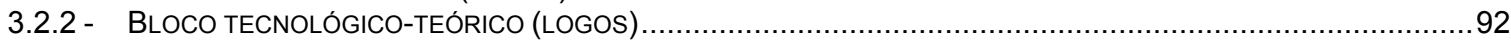

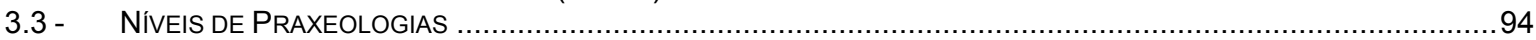

3.4 - RELAÇÃO ENTRE INDIVÍDUO (X) E OBJETO (O) NO PROCESSO DE CONTEXTUALIZAÇÃO. .................................98

3.5 - ANÁlISE DE ATIVIDADES POR NÍVEIS DE RESSONÂNCIA: A NOÇÃO DE VEROSSIMILHANÇA PRAXEOLÓGICA (VP)......

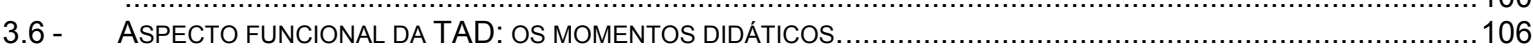

CAPÍTULO 4 - MÉTODOS DE ANÁLISE E DADOS. .........................................................................115

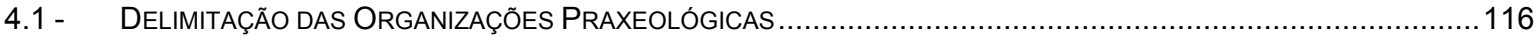

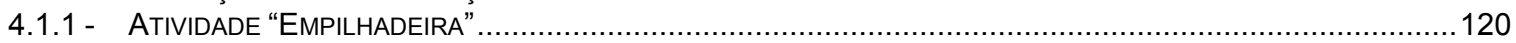

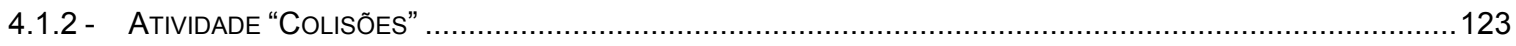

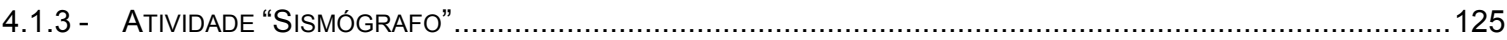

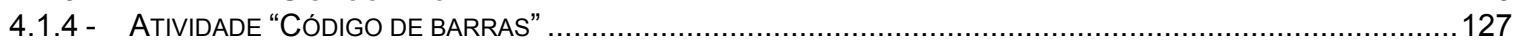

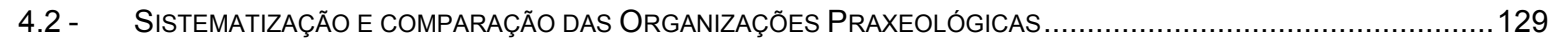

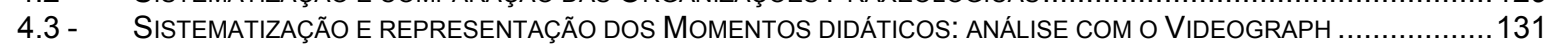

CAPÍTULO 5 - RESULTADOS E DISCUSSÕES .................................................................................137

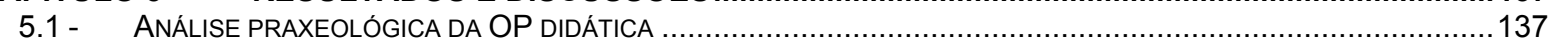

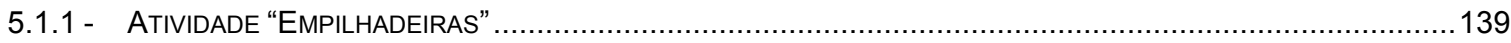

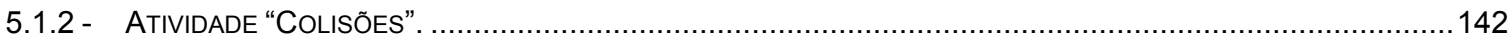

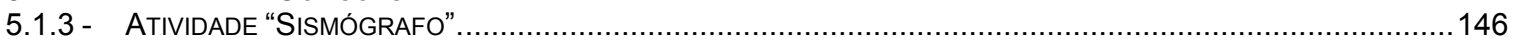

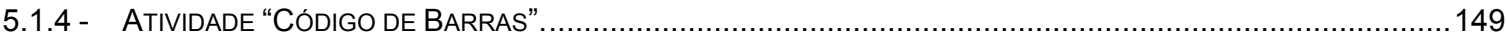

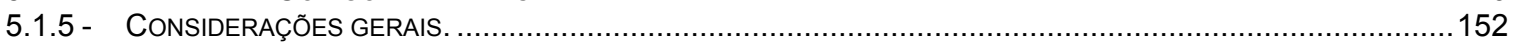

5.2 - CONTEXTUALIZAÇÃO NO ENSINO DE FÍSICA: ANÁLISE DE ATIVIDADES POR VEROSSIMILHANÇA PRAXEOLÓGICA. 153

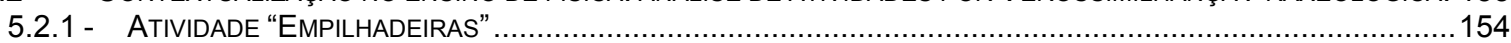

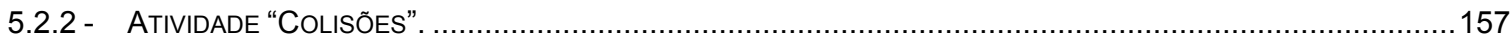

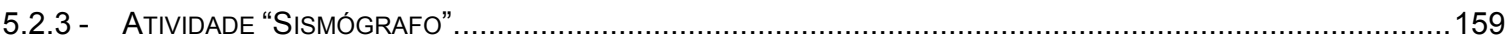

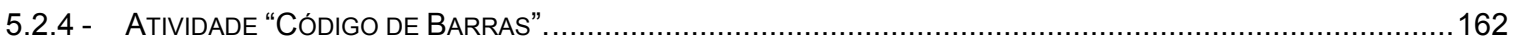

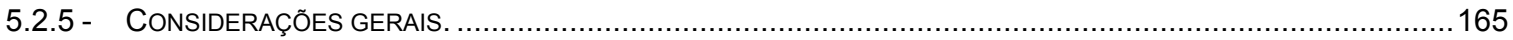

5.3 - ANÁLISE DOS MOMENTOS DIDÁTICOS: A RELAÇÃO DO INDIVÍDUO COM OS OBJETOS NO PROCESSO DE

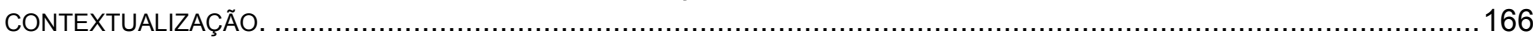

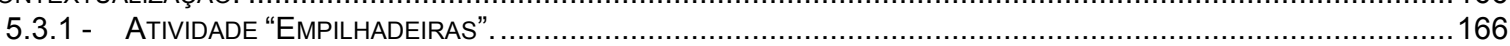

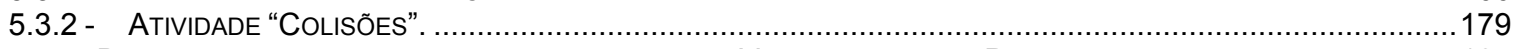

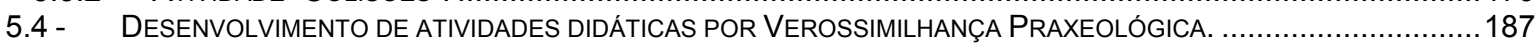

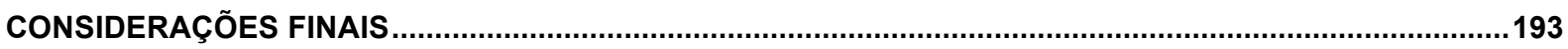

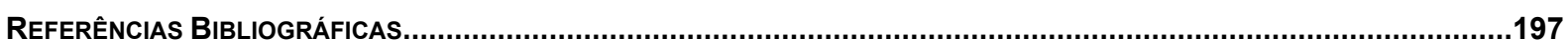

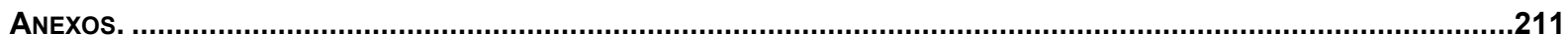





\section{APRESEnTAÇÃo}

As atividades experimentais no ensino de ciências sempre foram muito atrativas para mim desde o ensino fundamental. Participar das tradicionais feiras de ciências escolares era como estar em um verdadeiro parque de diversão, especialmente quando demandava construção de protótipos e maquetes. Além do aspecto praticamente artesanal dessa atividade, me instigava poder lidar experimentalmente com fenômenos da natureza observados em diferentes mecanismos e ambientes, isso quando conseguia vislumbrar essas correlações! Também me intrigava o que estava por detrás das coisas, ou seja, qual era o princípio básico para seu funcionamento. Como era possível um determinado "artefato", especialmente tecnológico, fazer isso ou aquilo? Uma das mais remotas lembranças que tenho da infância é a tentativa eloquente de descobrir qual o mistério por detrás do som que provinha de um velho brinquedo em formato de telefone. O que havia dentro daquela "caixa-preta"? Quem ou o que estava emitindo tal som (não me lembro bem ao certo se era som de discagem ou de uma voz)? Sei que, na tentativa desesperada de saciar minha curiosidade ingênua, bati várias vezes esse brinquedo no chão até conseguir abrir e ver o que tinha dentro. Resultado? Um brinquedo quebrado que não fazia mais nada!

Até o término do ensino fundamental, confesso que gostava muito do ensino de ciências. Entretanto, ao ingressar no ensino médio, mais especificamente, no antigo magistério, não sentia mais satisfação em aprender as disciplinas científicas, agora separadas em química, física e biologia. Os motivos são diversos, desde mudanças dos métodos de ensino e do corpo docente, até o próprio conteúdo disciplinar, que se mostrava maçante e burocrático. Somado a isso, por se tratar de um ensino médio profissionalizante, meu contato com essas disciplinas se reduziu apenas ao primeiro ano do ensino médio. Todavia, o gosto pela ciência, especialmente seu componente experimental, ainda estava latente. Como afirmou um amigo meu durante nossa graduação, "adoro física, porém, detesto o curso de física”. A ciência não deixou de ser interessante para mim, porém, meu ensino médio não me estimulava nem um pouco a me aventurar nesse caminho. Como, então, fui parar na física?

Durante os últimos anos do ensino médio, costumava "matar aula" para visitar a universidade local (Universidade Federal do Rio Grande do Norte - UFRN), especialmente a biblioteca e o departamento das exatas que continha painéis informativos e aparatos 
experimentais expostos em alguns corredores. Nesse "intercâmbio acadêmico-cultural clandestino", meu espírito era alimentado por inúmeros devaneios de moto-perpétuos e princípios da invisibilidade, chegando ao ponto de procurar alguns professores para discutir minhas ideias mirabolantes. Num desses encontros e escapadas das aulas do ensino médio, conheci o prof. Ciclâmio Leite Barreto e fui indagado sobre qual curso pretendia fazer. Entre um argumento e outro, fui motivado por ele a prestar vestibular para o curso de física, uma vez que minhas conversas e devaneios apresentavam relações com esse campo do saber. Confesso que nem sabia direito o que era física, especialmente porque só cursei essa disciplina no primeiro ano do ensino médio e, por quase quatro meses, só tive aulas sobre vetores. Bem, apesar disso, prestei o vestibular por duas vezes até que consegui entrar no curso de física da UFRN.

Logo no primeiro semestre de curso, procurei vários professores para ingressar de forma voluntária em algum grupo de pesquisa; não via a hora de "colocar a mão na massa"! Consegui desenvolver alguns trabalhos dessa maneira, mas logo as dificuldades acadêmicas para acompanhar o curso (bacharelado) e questões de ordem financeira forçaram-me a repensar o caminho a ser seguido. Com isso, por já ter certa experiência na área educacional e pelo fato da licenciatura ocorrer em período noturno, possibilitando-me a oportunidade de trabalhar e, ao mesmo tempo, continuar minha formação acadêmica, decidi mudar de habilitação, ou seja, ir para a licenciatura. Após alguns meses dessa mudança, com o auxílio do marido da minha tia Ducineide Alves, o artista plástico Vatenor de Oliveira, consegui um estágio de meio período em uma galeria de artes. Além disso, consegui nessa mesma época, por indicação do prof. José Ferreira Neto, uma bolsa de iniciação científica (IC) na área de ensino de astronomia (dois temas que também me instigavam muito, ensino e astronomia), sob a orientação do prof. Luiz Carlos Jafelice.

Ao longo do período de vigência daquela bolsa (dois anos), fui, aos poucos, tendo cada vez mais contato com diferentes pesquisas na área de ensino de ciências, o que, por indicação do professor André Ferrer, me levou ao mestrado acadêmico no Instituto de Física da Universidade de São Paulo, sob orientação do prof. João Zanetic.

Seja como professor, através das aulas que ministrava e do desenvolvimento de atividades didáticas, ou como pesquisador, participando de projetos e discussões, sempre que possível voltava minha atenção para as questões de ordem prática e experimental no ensino de física e astronomia, bem como tentava integrar diferentes contextos ao conteúdo a ser 
ensinado. Somado a isso, desde a graduação apresentei certa afinidade e habilidade no uso de tecnologias digitais, tanto para fins didáticos quanto técnicos, o que me levou, por intermédio do prof. Ivã Gurgel, a conseguir uma bolsa de apoio técnico no Laboratório de Pesquisa em Ensino de Física (LaPEF), sob orientação do prof. Maurício Pietrocola, assim que ingressei no mestrado, em 2007.

No ano seguinte, em 2008, a Lego Education do Brasil reuniu profissionais com o intuito de elaborar e escrever atividades de robótica a serem utilizadas em aulas de física do ensino médio. Por meio do LaPEF e do Núcleo de Pesquisas em Inovação Curricular (NUPIC), dos quais eu era integrante enquanto ainda cursava o mestrado, tomei conhecimento desse projeto e fui convidado à integrar a equipe. Esse foi, portanto, meu primeiro contato com a robótica educacional propriamente dita.

Apesar de, à época, já ter participado de projetos e pesquisas envolvendo o uso de tecnologias digitais e atividades experimentais no ensino de física (BROCKINGTON et al, 2008; SCHIVANI et al, 2006), esse projeto apresentou desafios que até aquele momento não havia enfrentado, a exemplo do próprio desenvolvimento das estruturas físicas (sistemas robóticos) usando os kits disponibilizados (\#9797 LEGO Mindstorms NXT) para, de forma adequada, trabalhar determinados conceitos e teorias da física. Algumas grandezas físicas, como temperatura, corrente elétrica e campo magnético, não eram possíveis de serem exploradas diretamente com esses kits em particular, uma vez que estes possuíam apenas sensores de luz, som, ultrassom, contato físico e de giro (através do servo motor). Esse desafio inicial nos conduziu a outros materiais que interagiam com os kits de robótica da Lego, como alguns dos sensores da empresa Vernier que, através de um adaptador, podiam se comunicar com o NXT (bloco de comando e processamento do kit). Dessa forma, ampliaramse consideravelmente as opções de recursos a serem utilizados nas montagens e, consequentemente, o número de atividades possíveis de serem desenvolvidas para se discutir determinados fenômenos e conceitos da física.

Para o primeiro ano do ensino médio, foram desenvolvidos quatro fascículos (um por bimestre), totalizando 16 atividades para explorar os conteúdos de mecânica. Da mesma forma ocorreu para o segundo ano, porém, com atividades direcionadas para se trabalhar conteúdos envolvendo termodinâmica, meio ambiente e ondas, modos de percepção e armazenamento de informação e entretenimento (PIETROCOLA et al, 2010, 2010b). Foram desenvolvidas também atividades relacionadas aos conteúdos do terceiro ano do ensino 
médio, entretanto, devido às dificuldades técnicas para adequação dos sensores, de modo a atender as montagens sugeridas, e devido também à impossibilidade de inclusão de novos materiais nos kits de robótica, só foram publicados os fascículos para o primeiro e o segundo ano do ensino médio. As atividades foram construídas considerando a utilização de um kit de montagem para cada grupo de quatro alunos, acompanhado de um fascículo didático (revista Lego Zoom) para cada estudante. O professor teria duas aulas a cada quinze dias para aplicar essas atividades, com o intuito de iniciar ou ampliar um conteúdo, discutir e propor novas situações. Essas atividades foram elaboradas concebendo-se uma situação problema por meio da criação e do desenvolvimento de montagens de robôs e utilização de sensores para coleta de dados. Após esta etapa, as montagens e estruturas físicas dos "robôs" eram então otimizados pela equipe da Lego para, posteriormente, serem escritos os fascículos do aluno e também do professor. Essas propostas tiveram como principal preocupação fazer com que os conceitos da física fossem utilizados de forma clara para se resolver um problema proposto aos alunos a partir de contextos extraídos de situações cotidianas, apresentadas inicialmente por meio de uma história em quadrinhos. Por fim, para a elaboração, estruturação e desenvolvimento dessas atividades, utilizamos como referencial metodológico os três momentos pedagógicos que envolvem a resolução de problemas, a saber: i) problematização inicial; ii) organização do conhecimento; iii) aplicação do conhecimento (ANGOTTI \& DELIZOICOV, 2002; DELIZOICOV, 1991, 2005).

Em meio a esse intenso processo de pesquisa e desenvolvimento, observamos claramente o rico potencial educacional que esses recursos apresentavam para o ensino de ciências, especialmente por permitir explorar, em sala de aula, uma vasta gama de situações cotidianas e fenômenos físicos. Em contrapartida, éramos confrontados constantemente sobre a pertinência desse ou daquele material na investigação e resolução das situações-problema. Em outras palavras, nosso grupo se questionava se determinada montagem era pertinente e se estava, de fato, dialogando com as situações cotidianas que se desejava contextualizar, questionava-se igualmente até que ponto aquele recurso (robótica educacional) estava favorecendo o ensino e aprendizagem dos saberes disciplinares. De certo modo, esse processo de avaliação era um tanto intuitivo e com base na experiência de professor e na pesquisa de cada membro da equipe, ou seja, não havia (ou não se conhecia) mecanismos teóricometodológicos claros que indicassem se essa ou aquela atividade, através da robótica educacional, estava, de fato, favorecendo a contextualização no ensino de física. Iniciavam-se, portanto, os primeiros questionamentos que resultariam nesta tese. 
Pouco tempo depois de finalizado o referido projeto com a Lego, o professor Maurício Pietrocola tomou conhecimento, por intermédio de um grupo de pesquisa europeu, do desenvolvimento de sistemas robóticos voltados para o setor educacional usando um novo tipo de plataforma de prototipagem eletrônica de hardware livre, o Arduino. Com esse dispositivo, era possível utilizar uma ampla variedade de sensores e mecanismos de custo relativamente baixo, alguns até mesmo retirados de sucatas, para construir sistemas robóticos como, por exemplo, veículos, androides, casas inteligentes, dentre outros. Entretanto, o nível técnico exigido em eletrônica básica e em programação dificultava o desenvolvimento de montagens mais complexas e, consequentemente, sua inclusão no cenário educacional, especialmente na educação básica.

Nosso objetivo não era, e nunca foi, a robótica pela robótica, mas sim utilizar seu potencial para discutir e trabalhar, em sala de aula, contextos extraídos de situações cotidianas diversas dos estudantes ou presentes na sociedade em geral. Dessa maneira, outra questão que se apresentou foi: até que ponto os aspectos de ordem técnica sobrepujavam os de ordem didático-pedagógica nas atividades de ensino, independente do material ou kit de robótica utilizado. Essas questões e desafios foram aos poucos compondo o pano de fundo do meu projeto de pesquisa para o doutorado.

Entretanto, era preciso ainda identificar um referencial teórico e metodológico adequado que permitisse analisar esse cenário. Dificuldade sanada quando o professor Maurício Pietrocola sugeriu verificar a noção de Praxeologia, componente estrutural da Teoria Antropológica do Didático (TAD) (CHEVALLARD, 1999). A TAD pode ser empregada para entender as ações e atividades humanas que são representadas e permite ainda modelar e organizar o conhecimento por meio de uma Organização Praxeológica (OP), composta de dois blocos distintos, porém correlacionados: o bloco prático-técnico, correspondendo ao saber-fazer, e o bloco tecnológico-teórico, ligado ao saber, ou seja, ao discurso lógico que permite melhor compreender e justificar o bloco prático-técnico. Além disso, uma organização praxeológica pode ser de diferentes tipos: didática, física, matemática, química, artesã, industrial, doméstica, etc. Dessa maneira, constatamos que a TAD poderia, não só fomentar a análise das atividades didáticas que fazem uso da robótica educacional no ensino de ciências, investigando correlações entre os blocos prático-técnico e tecnológicoteórico, como também possibilitaria investigar o quanto essa mesma atividade dialoga (ou não) com as situações que se deseja contextualizar. 
Sob essa nova perspectiva, começamos a revisitar as atividades desenvolvidas em projetos anteriores, a fim de melhor compreender suas estruturas e as interconexões com as situações cotidianas trabalhadas. Quais os contextos e recursos didáticos adequados para se trabalhar determinadas técnicas e tecnologias em sala de aula no ensino de fisica? Quais técnicas possibilitam realizar determinadas tarefas mais eficazmente? De que maneira ocorre (ou não) a contextualização? Essas foram algumas das questões que levantamos inicialmente para (re)pensar a contextualização e o uso de recursos digitais, atrelados a materiais diferenciados, no ensino de física na educação básica. Nesse percurso, iniciamos esta tese com o capítulo 1 discutindo os movimentos de reforma, influências e crises que sofreu (ou sofre) o ensino de ciências, bem como as múltiplas faces identificadas na literatura para o conceito de contextualização.

As questões centrais, o recorte e os objetivos da pesquisa são apresentados no capítulo 2. Neste capítulo, há um breve panorama sobre as tecnologias digitais, especialmente sobre a robótica, no qual se discorre sobre os desafios para sua utilização no âmbito educacional, e também há uma análise sobre materiais disponíveis, além de abordar seu potencial para promover a contextualização no ensino de física.

Na sequência, a TAD é apresentada e discutida em detalhes no capítulo 3. Esse capítulo expõe uma discussão de caráter teórico, na qual a relação entre o indivíduo (X) e os objetos $\left(\mathrm{O}_{\mathrm{n}}\right)$ de uma dada prática social de referência, configurando na relação $\mathrm{R}(\mathrm{X}, \mathrm{O})$, é tratada como fundamental no processo de contextualização. Além disso, apresenta também as noções de Organização Praxeológica (OP), de momentos didáticos e de Verossimilhança Praxeológica (VP), esta última desenvolvida por nós para (re)pensar a contextualização nesse cenário educacional. Desse modo, nossa pesquisa está centrada, de forma mais contundente, na dimensão epistemológica da relação entre atividades didáticas e práticas de referência.

Já o capítulo 4 apresenta os aspectos metodológicos da pesquisa, tais como métodos de análise dos momentos didáticos, delimitação do material instrucional analisado, local e público para aplicação desse recurso e estratégias para expor, de maneira organizada e estruturada, as organizações praxeológicas identificadas, tanto na atividade didática quanto nas práticas sociais de referência contextualizadas.

Em seguida, o capítulo 5 discute os principais resultados alcançados, tanto os provenientes da análise praxeológica do material instrucional investigado, quanto aqueles provenientes da aplicação em sala de aula, observando, dessa forma, a dinâmica dos 
momentos didáticos e as possíveis implicações para o processo de contextualização. Investigam-se também possíveis alterações na relação $\mathrm{R}(\mathrm{X}, \mathrm{O})$ no decorrer do processo de contextualização, cujo principal objetivo propõe-se ser justamente o de fomentar mudanças nessa relação. Por fim, discute o desenvolvimento de atividades didáticas com base nos resultados alcançados e dentro da perspectiva teórico-metodológica adotada. 


\section{Capítulo 1 - INTRODUÇÃO}

Quando o espírito se apresenta à cultura científica, nunca é jovem. Aliás, é bem velho, porque tem a idade de seus preconceitos. Aceder à ciência é rejuvenescer espiritualmente, é aceitar uma brusca mutação que contradiz o passado.

Gaston Bachelard ${ }^{1}$

Rejeitar, em qualquer nível, a problematização dialógica é insistir num injustificável pessimismo em relação aos homens e à vida. É cair na prática depositante de um falso saber que, anestesiando o espírito crítico, serve à "domesticação" dos homens e instrumentaliza a invasão cultural.

Paulo Freire $^{2}$

\section{1 - O ensino de ciências: crises, influências e reformas}

A ciência passou a integrar o currículo escolar da educação básica no século XIX, tanto na Europa quanto nos Estados Unidos da América (EUA). Em grande parte, este fato foi resultado de esforços dos próprios cientistas, dentre eles o biólogo britânico Thomas Henry Huxley (1825-1895), principal defensor público da teoria da evolução de Charles Darwin, e o físico e químico inglês Michael Faraday (1791-1867), pioneiro no estudo das conexões entre eletricidade e magnetismo (DeBOER, 2000).

\footnotetext{
${ }^{1}$ In. Formação do espírito científico. Rio de Janeiro, Editora Contraponto, 1996, p. 18.

${ }^{2}$ In. Extensão ou Comunicação? $3^{\mathrm{a}}$ edição, Rio de Janeiro: Editora Paz e Terra, 1977, p. 55.
} 
Faraday desenvolveu vários trabalhos de divulgação científica para o grande público, dentre os quais destaco a criação de dois ciclos de palestras, o "Friday Evening Discourses" e o "Christmas Lectures", ambos iniciados em meados de 1820 e mantidos até os dias de hoje pela Royal Institution (ROYAL INSTITUTION, 2014; BALDINATO, 2009). Embora a ciência já se encontrasse alojada na educação profissional em nichos de formação específica, como no caso dos oficiais artilheiros e em certos setores industriais, na perspectiva de uma educação geral é no século XIX que se começa a refletir sobre o papel da ciência na sociedade. De um modo geral, argumentava-se, nesse período, sobre a importância da prática da ciência e de seus produtos em um mundo cada vez mais dominado por ela e pela tecnologia. Durante os primeiros anos do século XX, o ensino de ciências foi se consolidando, mais justificado (em especial, pela National Education Association's - NEA) com base em sua relevância para a vida contemporânea e em sua contribuição para uma compreensão compartilhada do mundo pelos membros da sociedade. Expressava-se certeza na relação entre ciência e o progresso humano, ideia que tinha sido uma parte muito importante do pensamento sobre ciência e tecnologia no século XIX e início do século XX (ibidem).

Entretanto, a percepção sobre a relação entre ciência e sociedade recebeu valiosas e antagônicas lições das duas grandes guerras ( $1^{\mathrm{a}}$ Guerra Mundial, de 1914 a 1917, e $2^{\text {a }}$ Guerra Mundial, de 1939 a 1945). Se por um lado, ficou claro que a ciência e as tecnologias foram determinantes nos resultados de ambas as guerras, por outro, constatou-se que a ciência e a tecnologia e seus produtos também apresentavam um potencial para destruir a sociedade e a própria natureza. Esses dois tipos de resultados antagônicos geraram movimentos diferentes. Um deles traduzia a necessidade de se manter a política, a economia e a ciência interligadas de modo a garantir a soberania, o desenvolvimento e o poder das nações. Mas, também era preciso atentar-se para as atitudes e as relações do público para com a ciência, formar pensadores críticos sobre o papel da ciência na sociedade, produzindo, assim, novas razões para o ensino de ciências frente aos dramáticos acontecimentos.

Curiosamente, ao mesmo tempo em que se temiam determinados avanços científicos, esperava-se também formar cidadãos favoráveis à ciência, familiarizados com o trabalho de cientistas e engenheiros, uma vez que a ciência e o desenvolvimento tecnológico se mostravam recursos importantes para a segurança nacional. Nesse aspecto, os EUA por intermédio do President's National Research Board (Conselho Nacional de Pesquisa do Presidente), estabelecido para estudar atividades de pesquisa e de desenvolvimento do país e programas de treinamento de ciências após a guerra, afirmaram que: 
Cumpre ter em conta o grau de compreensão da ciência pela população em geral. Pois em uma democracia é sobre a atitude em relação à ciência popular, que a atratividade da profissão, a resultante seletiva para finalmente entrar na profissão, bem como o grau de apoio obtido para o seu trabalho vai depender. (President's Scientific Research Board, 1947, vol. 4, p. 113, apud DeBOER, 2000, p. 585).

Dez anos após esse apontamento e o registro dessa inquietação, é lançado em outubro de 1957, pela então União Soviética, o primeiro satélite artificial desenvolvido pelo homem, o Sputnik. Esse feito gerou enorme impacto na sociedade americana, e o então presidente dos Estados Unidos, Dwight David Eisenhower (1890-1969), convocou os membros do Science Advisory Committee (SAC) para pedir seus conselhos. Esse comitê era composto em sua maioria por físicos, dentre eles Isidor Isaac Rabi (1898-1988), prêmio Nobel de Física em 1944 e amigo de Eisenhower. Falando em nome do grupo, Rabi estabeleceu sete recomendações que incluíam: elevar o SAC para o President's Science Advisory Committee (PSAC); nomear um cientista como assistente presidencial e fortalecer a educação científica nas escolas públicas. "Hans Bethe ${ }^{3}$ estava presente nesta reunião e lembrou que Eisenhower ouviu atentamente os físicos, sondando as questões, e, em seguida, virou-se para seu ajudante e disse: 'Faça isso." (RIGDEN \& STUEWER, 2006, p. 113).

No geral, a guerra fria com a União Soviética é, talvez, o primeiro conflito que vem à mente. Esta longa batalha, tanto de armamento tecnológico, quanto de concepções políticas, definem o cenário para o surgimento de uma mentalidade do público que viu a educação científica do ensino médio em si como uma arma de um arsenal destinado a controlar as ambições soviéticas para dominar o mundo. (RUDOLPH, 2006, p. 01. Tradução nossa).

O resultado foi que os educadores de alguns países ocidentais questionavam seriamente o ensino científico desenvolvido em suas escolas, em virtude da aparente superioridade soviética nas ciências. Organizações internacionais patrocinaram encontros para debates e estudos sobre o ensino de ciências e, principalmente, sobre a necessidade de elaborar novos textos para diminuir a distância entre os países ocidentais e a União Soviética. A partir dos encontros foram organizados nos Estados Unidos e na Inglaterra centros e comitês nacionais para a produção de materiais didáticos. (BARRA \& LORENZ, 1986, p. 1972).

Com o lançamento do Sputnik e em meio à "guerra fria", os norte-americanos se viram em desvantagem tecnológica e forçados a intensificar seus programas de pesquisa aeroespacial, alertando também múltiplas esferas da sociedade americana da época sobre a necessidade de mudanças, principalmente, por que

\footnotetext{
${ }^{3}$ Hans Albrecht Bethe (1906-2005), Nobel de Física em 1967 por seus estudos em nucleossíntese estelar.
} 
[...] o lançamento do Sputnik, que mostrou um salto científico dos russos, aumentou a consciência sobre o papel da ciência na garantia da segurança nacional. Como resultado, o objetivo do ensino de ciências se tornou mais do que apenas contribuir para um aumento da produção de cientistas e engenheiros altamente especializados. Além disso, cada pessoa educada tinha de ser alfabetizada em ciência, porque a sociedade necessitava de cidadãos que poderiam apreciar e entender o que os cientistas e engenheiros estavam fazendo. (EIJCK, 2012, p. 1033, grifo nosso). Tradução nossa.

Novamente, como nos anos do pós-guerra, a comunidade norte-americana discutia a importância do papel estratégico do conhecimento científico na sociedade, propondo aos educadores de ciências que trabalhassem para produzir cidadãos que compreendessem ciência e fossem simpáticos ao trabalho dos cientistas, além de assumirem a responsabilidade cívica que havia surgido após a Segunda Guerra Mundial em relação às ameaças e promessas da ciência (DeBOER, 2000). Mas dessa vez, especialmente para vencer a corrida espacial, os Estados Unidos fizeram investimentos de recursos humanos e financeiros sem paralelo da história da educação, demonstrando que mudanças no sistema educacional, em particular no currículo de matemática e ciências dos norte-americanos, eram de interesse nacional (BYBEE, 1997; KRASILCHIK, 2000; RUDOLPH, 2006).

A justificativa desse empreendimento baseava-se na idéia de que a formação de uma elite que garantisse a hegemonia norte-americana na conquista do espaço dependia, em boa parte, de uma escola secundária em que os cursos das Ciências identificassem e incentivassem jovens talentos a seguir carreiras científicas. (KRASILCHIK, 2000, p. 86).

Nesse movimento de reforma, o objetivo do ensino era basicamente formar uma elite competitiva e especializada, capaz de impulsionar o desenvolvimento científico e tecnológico da sociedade americana. Para isso, vários projetos de reforma curricular e metodológica entraram em ação, hoje conhecidos como projetos de $1^{\text {a }}$ geração do ensino de Física (Physical Science Study Committee - PSSC), Química (Chemical Bond Approach - CBA), Biologia (Biological Science Curriculum Study - BSCS) e Matemática para o ensino médio (Science Mathematics Study Group - SMSG) (KRASILCHIK, 2000). Na Inglaterra, por meio da Fundação Nuffield, houve também financiamento de projetos para o ensino de química, física e biologia. "Esses projetos constituíram parte da resposta dada pelos Estados Unidos e Inglaterra à suposta superioridade do ensino de ciências nas escolas secundárias soviéticas". (BARRA \& LORENZ, 1986, p. 1973).

A orientação metodológica desses projetos (ditos de $1^{\mathrm{a}}$ geração) encorajava a substituição de experimentos meramente ilustrativos de fenômenos por experimentos de caráter investigativo, onde os estudantes eram estimulados a elaborar modelos explicativos. 
Além disso, houve substituição de livros descritivos da ciência, os compêndios, por livros explicativos de modelos científicos de forma a estimular o pensamento científico e a criatividade, e não a mera repetição (KRASILCHIK, 2000; ALVES FILHO, 2000; SANTOS \& PORTO, 2013).

\subsection{1 - Movimentos de reforma para o ensino de física}

De acordo com o pesquisador Alves Filho (2000, p. 26), “o maior representante do movimento inovador no ensino de ciências foi o projeto de Física do Physical Science Study Committee, mais conhecido pela sigla PSSC, iniciado em 1957 nos EUA.”. O PSSC era um projeto de renovação curricular da física voltado para o ensino médio, fruto também de uma grande insatisfação com o ensino de física naquela época nas escolas secundárias norteamericanas (RUDOLPH, 2006; CARVALHO, 1973; MOREIRA, 2000; PENA, 2012).

O físico e então professor do Massachusetts Institute of Technology - MIT, Jerrold Reinach Zacharias (1905-1986) reuniu um grupo de expoentes em física e em educação que deu origem ao projeto PSSC, os quais também trabalharam em todas as suas fases. Já o desenvolvimento do livro-texto contou com forte atuação do físico Francis Lee Friedman (1918 - ?), também professor do departamento de física do MIT. Os líderes do PSSC formaram um Comitê Gestor, que incluía Vannevar Bush (Engenheiro do MIT), James R. Killian (Engenheiro e $10^{\circ}$ Presidente do MIT), Edwin H. Land (Físico Industrial e então presidente da Polaroid Corporation), Edward M. Purcell (Físico de Harvard e Nobel de Física em 1952) e Isidor Isaac Rabi (Físico da Universidade de Columbia e Prêmio Nobel de Física em 1944).

O PSSC (Physical Science Study Committee) foi desenvolvido por uma equipe que reuniu cientistas, professores, psicólogos, escritores, fotógrafos, técnicos em filmagem e outros, num total de 282 pessoas cujos esforços estavam voltados para produzir um novo curso de Física para a escola secundária norte-americana. (FILOCRE \& GOMES, 1996, p. 297. Grifo nosso).

O PSSC teve início em 1956, a primeira ajuda financeira recebida veio de uma doação da National Science Foundation (NSF) e a manutenção do programa contou com apoio financeiro da Fundação Ford e da Fundação Alfred P. Sloan. As primeiras aplicações do material desenvolvido ocorreram entre 1957 e 1958, em oito escolas, totalizando em 300 (trezentos) estudantes, servindo de base para avaliar, revisar e ampliar o conteúdo e propostas de ensino. Ocorreram ainda outras duas aplicações, abrangendo aproximadamente 900 
(novecentos) escolas e mais de 37 mil alunos participantes. O curso foi então revisto à luz desta experiência e, já em 1960, o livro didático PSSC (Física) e outros materiais do curso entraram nas salas de aula em todo o país (EUA) (PSSC, 1963; RIGDEN \& STUEWER, 2006).

O PSSC teve o mérito de modificar substancialmente a percepção do que se entendia por ensino de Física até aquela época. Independente dos motivos políticos-ideológicos que justificaram sua elaboração, a proposta metodológica foi revolucionária. Um texto totalmente diferenciado, utilizando uma linguagem moderna, apresentava um sequencial de conteúdo novo e incorporava tópicos pouco explorados no corpo dos textos tradicionais. Questões abertas foram inseridas no próprio texto e o laboratório passa a fazer parte integrante do curso. A prática experimental tinha sua inserção, à medida que fazia a inter-relação com a teoria no desenvolvimento da Física. Como novidade, filmes, produzidos especialmente para o projeto, são agregados como ferramentas de ensino. (ALVES FILHO, 2000, p. 26).

Em contrapartida, apesar do enorme investimento, da variedade de recursos didáticos e de textos diferenciados, além de estratégias metodológicas inovadoras e dos nomes de peso envolvidos no desenvolvimento e aplicação desse projeto, somente cerca de 4\% dos estudantes dos Estados Unidos cursaram o PSSC, não obtendo o sucesso esperado e desejado no ensino secundário americano. "Foi por isso que a NSF solicitou minha ajuda, para tentar fazer algo mais abrangente, que alcance um público maior, por exemplo, envolvendo as estudantes, que raramente cursavam Física", afirma o físico Gerald Holton, professor da Universidade de Harvard, em entrevista conduzida por Bernardo Jefferson de Oliveira e Olival Freire Junior (OLIVEIRA \& FREIRE JUNIOR, 2006, p. 320).

Gerald Holton participou da produção do Project Physics Course (mais conhecido como Projeto Harvard) elaborado no início da década de 1970, sob um enfoque humanista, cujo objetivo era mostrar a Física enquanto construção humana e, portanto, sujeita a falhas e erros, além de estar sujeita a influências de fatores políticos, históricos, religiosos, filosóficos, dentre outros (CARVALHO, 1973; WELCH, 1973; OLIVEIRA \& FREIRE JUNIOR, 2006; PENA, 2012). Adotou-se uma abordagem metodológica denominada "Abordagem Conectiva", na qual "contribuições da História e da Filosofia da Ciência, bem como relações entre a Física e outras disciplinas científicas e atividades sociais, são fortemente valorizadas.” (OLIVEIRA \& FREIRE JUNIOR, 2006, p.315). Além disso, o Projeto Harvard investia fortemente no laboratório didático, com cerca de 50 (cinquenta) práticas experimentais, com alternativas para um mesmo experimento oferecendo diferentes procedimentos, estratégia nova até então (ALVES FILHO, 2000). Quanto ao público feminino e ao total de estudantes 
participantes do curso (lembrando que no sistema secundário norte-americano os alunos podem optar livremente por qual disciplina cursar), Gerald Holton ressalta que,

Tentamos atraí-las incluindo história de mulheres que tinham se sobressaído nas ciências. Acho que tivemos um certo sucesso. Mesmo assim muitos alunos ficaram de fora, pois apenas 20 a $25 \%$ dos estudantes daquele período seguiram nosso curso. Mas isso já era um avanço considerável comparado com os 4\% do PSSC. (OLIVEIRA \& FREIRE JUNIOR, 2006, p. 320).

Nesse movimento de renovação educacional em ciências e sobre influências do PSSC, além de tentativas para adequar os projetos às realidades locais e nacionais, a Inglaterra elaborou projetos próprios através da Fundação Nuffield, englobando física, química e biologia, voltados então para os cinco anos obrigatórios de ensino de ciências de acordo com a lei inglesa. O Projeto Nuffield, elaborado a partir de 1962, apresentou novas bases metodológicas, na qual se pensava um ensino de ciências capaz de levar o aluno, através de suas investigações e argumentos, a uma melhor compreensão do que é a ciência e do que significa ser um cientista. Para isso, contemplava exaustivamente determinados métodos de ensino, especialmente atividades de discussão e laboratório, com experimentos organizados em kits e distribuídos para cada dupla de alunos na tentativa de se desencorajar a simples demonstração (ALVES FILHO, 2000; MADDOX, 1966; CARVALHO, 1973).

Materiais mais sofisticados compunham o acervo de demonstrações à disposição do professor. A preocupação dos realizadores do projeto era criar condições para que o aluno se comportasse como um cientista, especialmente nas atividades ligadas ao laboratório didático. A divulgação do Projeto Nuffield ficou bastante restrita à Grã-Bretanha e suas antigas Colônias, não obtendo repercussão maior em outros países. (ALVES FILHO, 2000, p. 36).

Vários outros países entraram nesse movimento de renovação do ensino de ciências, alguns com forte apoio financeiro de fundações e organizações internacionais como a União Pan-Americana, a Organização das Nações Unidas para a educação, a ciência e a cultura (UNESCO), a Fundação Ford, a Fundação Rockefellar e a Fundação da Ásia. Desse modo, surgiram núcleos para produção de materiais didáticos em diversos países, como na Iugoslávia, Alemanha, Venezuela, Argentina, nas Filipinas, no Japão, Chile, Peru, entre outros (LORENZ, 2008).

No Brasil, o PSSC foi o projeto que teve maior repercussão, com sua tradução para o português liderada por uma equipe de professores do Instituto Brasileiro de Educação, Ciência e Cultura - IBECC (CARVALHO, 1973). Entretanto, antes mesmo do ingresso do PSSC em nosso território, o Brasil já apresentava iniciativas de renovação do currículo e das 
estratégias metodológicas para o ensino de ciências, especialmente no ensino de física e química, através da elaboração de atividades experimentais e livros-textos próprios conforme exposto a seguir.

\section{No cenário nacional}

Até meados do século XX, a maioria dos livros de ciências adotados nas escolas secundárias brasileiras constituía-se de traduções ou adaptações predominantemente de manuais europeus de física, química e biologia, caracterizados pela grande quantidade de informações apresentadas e carência de atividades e problemas para serem resolvidos pelos alunos. Enfatizava-se a transmissão e aquisição de conteúdos e não o desenvolvimento de habilidades científicas, focalizados em assuntos diretamente relacionados aos interesses das escolas do exterior (KRASILCHIK, 1980; BARRA \& LORENZ, 1986).

Esse quadro mudou com a criação, em 1946, do IBECC (Instituto Brasileiro de Educação, Ciência e Cultura) e, quatro anos depois, com a formação da Comissão Paulista dessa mesma instituição. Um dos projetos criados pela Comissão Paulista incluíam feiras, museus e clubes de ciências, pesquisas e treinamento de professores, além de produção de material didático, tais como livros-textos, equipamentos e material de apoio para práticas experimentais. "A meta geral desse projeto e, subsequentemente, de todos os projetos do IBECC que se seguiram foi melhorar o ensino de ciências nas escolas brasileiras pela introdução e adoção do método experimental na sala de aula”. (BARRA \& LORENZ, 1986, p. 1972).

Sob uma nova administração, em 1955, o IBECC desenvolveu um novo projeto denominado Iniciação Científica, cujo objetivo era produzir kits de experimentos com novos materiais, mais aperfeiçoados que os anteriores, seguidos de manual de instruções e folheto com leitura complementar, envolvendo assuntos de física, química ou biologia para estudantes do nível escolar primário e secundário, demonstrando, assim, que o Brasil já tinha uma história de promoção e reforma do ensino de ciências (BARRA \& LORENZ, 1986). Conforme destacou o pesquisador Isaias $\mathrm{Raw}^{4}$, secretário geral do IBECC (em 1955), seção de São Paulo, na apresentação do PSSC traduzido para o português brasileiro (edição

\footnotetext{
4 Membro da Academia Brasileira de Ciências desde 1987 e diretor do Instituto Butantã entre 1993 e 1997, atua principalmente da área de ciências biomédicas e dedicou-se fortemente para a criação de importante grupos e institutos de pesquisa, dentre eles a FUNBEC, uma indústria de equipamentos médicos e científicos, de onde saíram os primeiros eletrocardiógrafos, monitores, cardioversores, pHmetros e fotocolorímetros produzidos no Brasil, e o Centro de Biotecnologia no Instituto Butantã. Fonte: http://www.abc.org.br/ iraw Acesso em 20 de Abril de 2014. 40
} 
preliminar de 1963),

A ciência vem evoluindo com velocidade crescente. $O$ número de informações disponíveis dobra aproximadamente a cada dez anos. Mais rapidamente ainda cresce a aplicação da Ciência e seu impacto na vida diária, tornando cada vez maior o problema do ensino básico de Ciências ao jovem.

Este grave problema foi relegado pelo Homem de Ciência até bem recentemente. [...]

Em 1950, organizamos o IBECC-UNESCO, Seção de São Paulo, iniciando entre nós um movimento, através do qual chamávamos a atenção para a importância do problema, e alertávamos os cientistas para liderarem a reforma do ensino de ciências. Lutando contra a indiferença do Homem de Ciência, preocupado com a marcha de seu setor de investigação, conseguimos lentamente, nos anos seguintes, prosseguir em nossas atividades, e, em 1954, já desenvolvíamos um amplo programa para atacar os problemas mais agudos e característicos de nossa formação, particularmente o do desinteresse pela experimentação. (PSSC, 1963, p. 5. Grifo nosso).

Interessante notar a preocupação em fortalecer as atividades práticas em ciências e também a preocupação que tal atividade no cenário educacional (nacional e internacional) contasse com forte atuação dos próprios cientistas, indicando, assim, uma perspectiva pragmática do ensino de ciências que se sobressaía na época, cujo principal objetivo era a formação de elites na tentativa de atrair jovens talentos para seguir carreiras tecnológicas e científicas e, então, atender as demandas da época. No Brasil, a preparação dessa "elite" era defendida para impulsionar o progresso da ciência e tecnologia nacionais das quais dependia o país em processo de industrialização (KRASILCHIK, 1987, 2000).

Ao final da década de 1950, os projetos promovidos pelo IBECC começaram a ser fortemente influenciados pelos movimentos de reforma do ensino de ciências no âmbito internacional, especialmente dos norte-americanos. Nesse período, o IBECC contou com importante soma de doações financeiras, principalmente das Fundações Rockefellar e Ford. Para se ter uma ideia, em 1959, a Fundação Ford (também motivada pela corrida espacial contra a então União Soviética) lançou seu programa de assistência técnica à América Latina objetivando melhorias do ensino de ciências nos países do hemisfério sul. Nesse programa, entre 1961 e 1962, o IBECC conseguiu um apoio financeiro que totalizavam 170.000 (cento e setenta mil) dólares americanos (valores da época) para a produção e distribuição de kits, cursos de treinamento de professores de ciências, além da utilização em território nacional (após tradução e adaptação) dos materiais didáticos de ciências elaborados nos grandes projetos curriculares nos Estados Unidos (MAYBURY, 1975; BARRA \& LORENZ, 1986). 
$\mathrm{O}$ apoio financeiro veio em um momento oportuno para o IBECC, devido à Lei de Diretrizes e Bases da Educação Nacional (Lei $\mathrm{n}^{\circ}$ 4.024, de 20 de dezembro de 1961) que, em 1961, eliminou os programas federais obrigatórios que constituíam o maior obstáculo à reforma curricular no âmbito nacional e à introdução de projetos curriculares estrangeiros, como aqueles divulgados pelo IBECC.

A mudança na política educacional nacional criou um ambiente de receptividade para os projetos do IBECC. Entre 1961 e 1964, o Instituto conseguiu introduzir no Brasil a Versão Verde do BSCS e os textos de PSSC e CBA, englobando, portanto, os estudos de Biologia, Física e Química. (BARRA \& LORENZ, 1986, p. 16).

Em relação à presença do PSSC em território nacional, além dos apoios financeiros concedidos pelas Fundações Ford e Rockefeller, alegava-se que:

Que razão nos levou a escolher o Curso do PSSC para o Brasil? Não foi certamente porque não dispúnhamos de vinte milhões de dólares para realizar um projeto semelhante, ou porque não contássemos com um grupo de físicos de igual envergadura, ou porque não estivéssemos habituados a ensaiar cientificamente projetos de inovações no ensino que envolvessem o futuro de nossa mocidade. Fizemo-lo porque nos convencemos de sua excelência, acompanhando cuidadosamente sua evolução nos Estados Unidos, desde seu início, e realizando alguns testes no Brasil. E em 1961, enviamos aos E.U.A. um dos elementos de nossa equipe de professores, para participar de um Curso de Verão, através do qual tomamos contato direto com o Curso do PSSC. (PSSC, 1963, p. 5).

Entre 1962 e 1963, houve no Brasil dois cursos de formação de professores com vistas à utilização dos materiais do PSSC. De acordo com Alves Filho (2000), o PSSC teve como porta de entrada, no Brasil, as disciplinas de Instrumentação para o Ensino de Física dos cursos de nível superior, estimulando e formando toda uma nova geração de professores. Entretanto, o "sucesso" do PSSC no Brasil ficou restrito a esses cursos de formação e a influência exercida nos professores quanto aos aspectos metodológicos e técnicas de discussão, uma vez que o número de professores que adotaram e seguiram tal obra em seus cursos da educação básica foi muito pequeno (CARVALHO, 1973). Dentre as razões apontadas para a não adoção do PSSC por um número significativo de professores, estão a falta de condições básicas nas próprias escolas como, por exemplo, ausência de salas para o laboratório, inacessibilidade aos filmes e aos equipamentos necessários para projeção e para realização das atividades propostas nos livros-textos e manuais (CARVALHO, 1973; BARRA \& LORENZ, 1986).

Ainda em 1962, o IBECC, na $1^{\text {a }}$ Reunião de Secretários Executivos das Comissões Nacionais da Unesco, realizada naquele ano, tomou conhecimento de um projeto para desenvolver o ensino de física na América Latina, que culminou no Projeto Piloto de Física. 
Apoiado pelo então Departamento de Física da USP, pela Unesco e pelo Serviço de Recursos Audiovisuais do Centro Regional de Pesquisas Educacionais de São Paulo, foram produzidos vários livros-textos, materiais para experimentos de baixo custo para os estudantes e filmes de 35 e 16mm de curta duração sobre o tema "Física da Luz" (BARRA \& LORENZ, 1986; ALVES FILHO, 2000). Um aspecto interessante desse projeto era sua abordagem teóricometodológica por meio da Instrução Programada, fundamentada numa teoria behaviorista, pressupondo que a todo o estímulo corresponde uma resposta associada que, devidamente reforçada, condicionaria a resposta dada por meio do reforço positivo.

Para que esta teoria fosse usada na elaboração de textos, foi necessário desenvolver uma apresentação do conteúdo em pequenas parcelas, onde cada uma representasse um "estímulo" ao estudante. A este estímulo, o estudante deveria dar sua "resposta", sendo aplicado, de imediato, o respectivo "reforço". Seguindo estes princípios, o texto final tomou uma apresentação diferenciada dos textos tradicionais, optando por uma distribuição em quadros. (ALVES FILHO, 2000, pp. 38-39)

Com o passar dos anos e com apoio de Instituições como o IBECC, a Fundação Brasileira para o Desenvolvimento do Ensino de Ciências - FUNBEC (entidade complementar ao IBECC, destinada principalmente para comercialização dos materiais didáticos produzidos pelo Instituto), a Unesco, o Programa de Expansão e Melhoria do Ensino - PREMEN (dedicado também à produção de materiais didáticos, porém, visando uma melhor adequação às condições e necessidades das escolas brasileiras) e das Fundações Rockefellar e Ford, inúmeros projetos e programas de reforma do ensino de ciências foram desenvolvidos, implantados e avaliados no Brasil. Entre os anos de 1950 e 1980, contabilizase ao todo mais de 40 projetos curriculares, nos quais foram produzidos materiais didáticos dos mais diversos, voltados majoritariamente para o ensino de química, física e biologia (BARRA \& LORENZ, 1986).

Sob influência, direta ou indireta, dos projetos norte-americanos de primeira geração para o ensino de ciências, bem como na tentativa de melhor adequar os movimentos de reforma curricular para a realidade cultural e econômica da nação e dos estados, além de envolver outras perspectivas teórico-metodológicas, o Brasil desenvolveu, ainda, outros projetos para o ensino de física, dentre os quais destacamos o Projeto de Ensino de Física PEF (pelo Instituto de Física da Universidade de São Paulo), o Física Auto-Instrutiva - FAI (elaborado pelo Grupo de Estudos em Tecnologia de Ensino de Física - GETEF, USP) e o Grupo de Reelaboração do Ensino de Física - GREF.

O Projeto de Ensino de Física (PEF), desenvolvido no início de 1970 e com origens no 
primeiro Simpósio Nacional de Ensino de Física (I SNEF), compreendia um conjunto de experimentos e textos voltados para estudantes do então $2^{\circ}$ grau, com apoio de cursos de formação para professores de todo o Brasil. A realização dos experimentos, estreitamente ligados ao texto, tinha caráter obrigatório, deveriam ser realizados por todos os alunos. Optouse por trabalhar apenas com os conteúdos de Mecânica, Eletricidade e Eletromagnetismo tendo em vista a redução da carga horária dos cursos de física na escola secundária (Lei 5.692/70). Assim, o PEF enfatizava atividades práticas para os alunos por meio de material simples, abordagem mais conceitual com menos formalizações matemáticas, e apresentava uma física contemporânea (ALVES FILHO, 2000; NARDI, 2005). Interessante notar que, para atender essa ênfase conceitual, nos textos produzidos pelo PEF “o linguajar escrito se apresenta em um crescente, isto é, de frases mais simples e de um vocabulário menos formal, utilizados na Mecânica, passando pela Eletricidade com uma linguagem mediana até uma linguagem mais sofisticada e formal no Eletromagnetismo" (ALVES FILHO, 2000, p. 54).

Originado na mesma época que o PEF, o projeto Física Auto-Instrutiva (FAI) é fruto direto da insatisfação de professores de física do ensino médio de São Paulo-SP com o rendimento de seus estudantes e com os recursos utilizados. Desse modo, é formado o Grupo de Estudos em Tecnologia de Ensino de Física (GETEF), contando com a colaboração de 14 professores, em sua maioria da rede pública estadual de ensino. Sua base teórica segue a mesma linha que a do Projeto Piloto, ou seja, fundamentada numa abordagem behaviorista. Diferente do PEF, no FAI as atividades experimentais não se apresentam como elemento principal para motivar o educando e provocar discussões que levem a sistematização do conhecimento. Os propósitos assumidos pelo GETEF para desenvolvimento do FAI se resumiam em sete pontos básicos, a saber (ALVES FILHO, 2000, p. 49):

i. $\quad$ Fornecer ao professor uma nova metodologia de trabalho;

ii. Propiciar ao aluno uma possibilidade de aprendizagem efetiva pelo trabalho realizado (autoinstrução);

iii. Caracterizar o educador como elemento orientador, motivador, criador e avaliador dos resultados provenientes do processo de aprendizagem;

$i v$. Elaborar um texto baseado em um método de ensino individualizado que considerasse cada aluno como um ser individualizado com características próprias e deixasse margem para cada professor poder dar suas contribuições pessoais;

v. Elaborar instrumentos de laboratório adaptados às nossas condições de ensino;

vi. Elaborar textos históricos para poder propiciar aos estudantes uma visão da forma pela qual a ciência se desenvolve através do tempo;

vii. Elaborar recursos audiovisuais. 
Por fim, destacamos o Grupo de Reelaboração do Ensino de Física - GREF, desenvolvido por professores do Instituto de Física da USP na primeira metade da década de 1980. A proposta educacional do GREF, além de buscar um maior significado para o aprendizado científico dos alunos, independente das suas aspirações profissionais, pretendia também, simultaneamente, possibilitar o acesso a uma compreensão teórica e conceitual adequada da física para aqueles que pretendessem seguir carreiras universitárias e/ou técnicocientífica (ALVES FILHO, 2000).

O caráter prático-transformador e o caráter teórico universalista da Física não são traços antagônicos mas, isto sim, dinamicamente complementares. Compreender este enfoque permitiu evitar tanto o tratamento 'tecnicista' como o tratamento 'formalista' e, procurando partir sempre que possível de elementos vivenciais e mesmo cotidianos, formulam-se os princípios gerais da Física com a consistência garantida pela percepção de sua utilidade e de sua universalidade. (GREF, 1990, p. 15. Grifo nosso)

O GREF apresentava em seu livro-texto, tanto do professor quanto do aluno, situações do cotidiano (especialmente da região sudeste do Brasil), questões que eram exploradas gradativamente numa abordagem mais conceitual e com menos formalismo matemático, relacionando sempre que possível algum fenômeno observado com os conceitos e teorias da física. Para isso, eram propostas atividades como, por exemplo, entrevistas com pessoal especializado, pesquisas e observações de campo. Havia também espaço para desenvolvimento de experimentos, especialmente aqueles produzidos com material de baixo custo e que pudessem ser realizados pelos próprios alunos.

No entanto, de modo semelhante ao que havia acontecido com os projetos norteamericanos adotados no Brasil, os projetos nacionais, embora preocupados em oferecer materiais consoantes com a realidade brasileira, tiveram sua utilização em longo prazo e sua difusão nas escolas pouco significativas (KRASILCHIK, 1987; PENA \& FILHO, 2009; MOREIRA, 2000).

\section{2 - Novos debates, velhos problemas.}

De fato, o ensino de ciências, mais especificamente o ensino de física, sofreu influências de projetos e movimentos que buscavam, essencialmente, uma maior integração entre os saberes transmitidos nas escolas e as mudanças tecnológicas, ambientais, econômicas e políticas enfrentadas pela sociedade, além da própria evolução e das transformações sofridas constantemente pela ciência enquanto construção humana. Entretanto, mesmo com toda a 
mobilização pela qual passou o ensino de ciências, parece que alguns dos problemas do sistema educacional, vividos em décadas passadas, permanecem em nossa sociedade contemporânea (no Brasil e no exterior), especialmente quanto ao interesse dos estudantes em seguir carreiras de caráter puramente científicas. Nesse aspecto, Bybee e Fuchs (2006) relembram os movimentos de reforma em meio à corrida espacial entre os EUA e a extinta União Soviética, ressaltando que:

Sem aviso prévio, a comunidade de educação científica entrou em uma nova era de reformas. Nós pensamos que é fundamental reconhecer e definir as características desta reforma e o papel crítico que a pesquisa deve desempenhar. Quase 50 anos atrás, em outubro de 1957, os Estados Unidos aceleraram e expandiram os esforços para melhorar a educação científica. $\mathrm{Na}$ era Sputnik, os Estados Unidos tinham um único concorrente, a União Soviética. O principal objetivo era compreensível: ganhar a corrida espacial, enviando um homem à Lua e retorná-lo em segurança para a Terra. O cronograma foi claro: vamos atingir a meta até o final da década.

Agora, os Estados Unidos devem lançar novamente um grande esforço para melhorar a educação científica e tecnológica. Enquanto alguns expressam o temor de que "um novo Sputnik" possa ser necessária para mover a nação para a ação, argumenta-se que não devemos esperar por um evento como esse . É importante que a comunidade de educação científica reconheça a situação contemporânea, os Estados Unidos estão em perigo de perder sua vantagem competitiva na economia global. (BYBEE \& FUCHS, 2006, p. 349. Grifo nosso). Tradução nossa.

O alerta de Bybee e Fuchs (2006) compreende preocupações gerais com resultados de exames internacionais como o PISA ${ }^{5}$ (Programa Internacional de Avaliação de Estudantes), desenvolvido e coordenado pela Organisation for Economic Co-operation and Development (OECD). De modo geral, através da publicação dos resultados desses exames, constata-se ainda um relativo baixo interesse dos estudantes em seguir profissionalmente carreiras puramente científicas e também, principalmente nos países emergentes, constata-se um baixo rendimento em disciplinas como matemática e ciências (OECD, 2012, 2010 e 2007).

O processo de avaliação do PISA é trienal e envolve um grande número de países. É aplicado a estudantes na faixa dos 15 (quinze) anos, idade em que se espera já terem concluído o período da escolarização básica. O foco das avaliações são Leitura (em 2000), Matemática (em 2003) e Ciências (em 2006). Esse ciclo foi renovado e o programa iniciou uma nova sequência de avaliações sobre o domínio de Leitura (em 2009), Matemática (em

\footnotetext{
5 "Em cada país participante há uma coordenação nacional. No Brasil, o Pisa é coordenado pelo Instituto Nacional de Estudos e Pesquisas Educacionais Anísio Teixeira (Inep). O objetivo do Pisa é produzir indicadores que contribuam para a discussão da qualidade da educação nos países participantes, de modo a subsidiar políticas de melhoria do ensino básico. A avaliação procura verificar até que ponto as escolas de cada país participante estão preparando seus jovens para exercer o papel de cidadãos na sociedade contemporânea.” Fonte: http://portal.inep.gov.br/pisa-programa-internacional-de-avaliacao-dealunos Acesso em 15 de Janeiro de 2014. 46
} 
2012) e em Ciências (previsão para acontecer em 2015). Evidentemente, não devemos aceitar os resultados de tais exames sem um mínimo de reflexão crítica acerca de seus caracteres metodológicos, bem como sobre suas concepções e intenções políticas e formativas. Entretanto, também não devemos fechar os olhos para alguns de seus apontamentos.

No Brasil, apesar de uma tímida mudança positiva no quadro geral dos últimos anos de participação no PISA, constatou-se que apenas um baixo número dos estudantes avaliados, cerca de $0,3 \%$, apresentam boa performance em ciências, com capacidade para identificar, explicar e aplicar o conhecimento científico e o conhecimento sobre ciência em uma variedade de situações complexas da vida (OECD, 2012).

Em razão do pouco interesse dos estudantes para estudos e ingresso em carreiras puramente científicas, aliado ao baixo rendimento em disciplinas como física, química e matemática, vários países se viram forçados a lançarem projetos de reforma curricular e encontrar estratégias para reverter esse quadro. A Comissão Europeia, por exemplo, publicou um documento intitulado "Science Education Now: A Renewed Pedagogy for the Future of Europe", do qual destacamos a seguinte observação:

Nos últimos anos, muitos estudos têm destacado um alarmante declínio do interesse dos jovens por áreas chave da ciência e matemática. Apesar dos inúmeros projetos e ações que estão sendo implementados para inverter esta tendência, os sinais de melhoria ainda são modestos. A menos que uma ação mais efetiva seja tomada, a capacidade da Europa a longo prazo para inovar, e a qualidade da sua investigação também vão declinar. Além disso, entre a população em geral, a aquisição de competências que estão se tornando essencial em todas as esferas da vida, numa sociedade cada vez mais dependente do uso do conhecimento, também está sob ameaça crescente. (European Communities, 2007, p. 03).

Percebe-se nesse documento, dentre outras coisas, a preocupação com a formação do cidadão contemporâneo frente às necessidades do mundo moderno, mas também retoma a necessidade de formação de uma "elite" para atender o sistema como ocorreu fortemente nas décadas anteriores. Em linhas gerais, a Comissão Europeia, juntamente com a Agência Executiva relativa à Educação, ao Audiovisual e à Cultura (EACEA) (COMISSÃO EUROPEIA, 2012), apresentam três principais razões que são normalmente invocadas atualmente como elementos dinamizadores da elaboração de estratégias (políticas, econômicas, sociais, dentre outras) para melhorar o ensino de ciências, são elas:

i. o aumento do desinteresse pelos estudos nas áreas de ciências e pelas profissões com elas relacionadas; 
ii. a procura cada vez maior de investigadores e técnicos qualificados;

iii. a apreensão por ocorrer um possível declínio da inovação e, consequentemente, da competitividade econômica.

Dessa forma, em meio aos processos de reforma do sistema educacional, alguns governos procuram atingir seus objetivos através de medidas como (ibidem, p. 27):

- a implementação de reformas curriculares;

- a criação de parcerias entre escolas e empresas, cientistas e centros de investigação;

- o estabelecimento de centros de ciência e outras organizações afins;

- a instauração de medidas de orientação específicas para incentivar um maior número de jovens, sobretudo de mulheres, a optar por profissões científicas;

- a cooperação com universidades para melhorar a formação inicial dos professores;

- o lançamento de projetos cujo eixo é a formação profissional contínua.

É interessante notar mais uma vez a exigência por reformas curriculares e a preocupação em atrair o maior número de jovens para o campo das ciências, especialmente o público feminino. Nesse ponto, há uma preocupação geral, principalmente por parte dos dirigentes de nosso mundo econômico e industrial, ao ver diminuir o número de jovens que seguem carreiras com forte base científica. "Alguns estimam, além disso, que a crise das profissões científicas provém principalmente do fato de a carreira de engenheiros não ser mais tão lucrativa, e minimizam as causas culturais do desinteresse constatado." (FOUREZ, 2003, pp. 111-112).

Em suma, os currículos de ciências, mais do que os de outras áreas do conhecimento humano, sofrem pressões sociais, políticas e econômicas por mudanças que objetivam adequá-los às necessidades e aos desafios originados na própria sociedade, questionando, assim, a pertinência dos conteúdos ensinados e formação oferecida. Além disso, a ciência, enquanto construção humana, está em constante evolução e transformações, portanto, é patente a exigência dessas reformas de tempos em tempos, seja no âmbito curricular ou didático-pedagógico, agregando na medida do possível um maior "significado" do saber transmitido ao educando. 


\section{3 - O mundo ao nosso redor e a física escolar.}

Pensar um ensino de física que esteja em sintonia com as constantes transformações e demandas sociais, especialmente tecnológicas, científicas e ambientais, envolve necessariamente pensar também nas possíveis reformulações e atualizações pelas quais o currículo de física pode e/ou deve passar. Talvez o caso mais patente dessa observação seja o da Física Moderna e Contemporânea (FMC). O mundo ao nosso redor sofre constantes e rápidas transformações, geradas principalmente pelas Ciências e Tecnologias modernas. Aparelhos e dispositivos como Televisores de Plasma, Liquid Crystal Display (LCD), LightEmitting Diode (LED), Organic Light-Emitting Diode (OLED), Reatores Nucleares, Satélites de Telecomunicação e Geoposicionamento, telas sensíveis ao toque (Touchscreen), Celulares, Tabletes, Smartfones e Tomógrafos, são alguns dos exemplos em que conceitos da FMC são aplicados e permeiam suas funcionalidades.

Nesse cenário de constantes transformações e demandas sociais, podemos citar ainda o movimento CTS (Ciência Tecnologia e Sociedade) (SANTOS, 2008; SANTOS \& MORTIMER, 1999; TRIVELATO, 1993), visto que:

Com o agravamento dos problemas ambientais e diante de discussões sobre a natureza do conhecimento científico e seu papel na sociedade, cresceu no mundo inteiro um movimento que passou a refletir criticamente sobre as relações entre ciência, tecnologia e sociedade. Esse movimento levou a proposição, a partir da década de 1970, de novos currículos de ensino de ciências que buscaram incorporar conteúdos de CTS. Isso ocorreu, sobretudo, em países do chamado Primeiro Mundo, que desenvolveram projetos relevantes nesse campo [...] (SANTOS, 2008, p.111).

Com isso, a pertinência do que se ensina na escola e a formação que ela oferece devem ser interrogadas constantemente. Faz-se necessário agregar nas atividades didáticopedagógicas questões, desafios e problemas de modo a contemplar algumas das mudanças ou condições tecnológicas, ambientais, econômicas, políticas e/ou científicas enfrentadas pela sociedade.

Mais que em outras áreas, no caso do ensino das ciências de modo geral, e da Física em particular, isso se torna evidente, pois, ao mesmo tempo em que os alunos convivem com acontecimentos sociais significativos estreitamente relacionados com as ciências e a Tecnologia e seus produtos, recebem na escola um ensino de Ciências que se mostra distante dos debates atuais. Muitas vezes, os alunos acabam por identificar uma Ciência ativa, moderna, e que está presente no mundo real, todavia, distante e sem vínculos explícitos com uma Física que só "funciona" na escola. Não é por outra razão que os professores frequentemente apontam a falta de interesse e 
motivação dos alunos como um dos obstáculos para a aprendizagem. (RICARDO, 2010, pp. 29-30).

De modo geral, esse panorama reforça mais uma vez a necessidade da escola rever os conteúdos ensinados e suas respectivas práticas educacionais. Dentre as recomendações curriculares oficiais do Ministério da Educação (MEC) para essa "reforma" do ensino de ciências no cenário nacional, encontram-se seis temas estruturadores, seguido de suas respectivas unidades temáticas para organização curricular, a saber (BRASIL, 2006, p.57):

- Tema 1 - Movimento, variações e conservações (unidades temáticas: fenomenologia cotidiana, variação e conservação da quantidade de movimento, energia e potência associadas aos movimentos, equilíbrios e desequilíbrios);

- Tema 2 - Calor, ambiente e usos de energia (unidades temáticas: fontes e trocas de calor, tecnologias que usam calor: motores e refrigeradores, o calor na vida e no ambiente, energia: produção para uso social);

- Tema 3 - Som, imagem e informação (unidades temáticas: fontes sonoras, formação e detecção de imagens, gravação e reprodução de sons e imagens, transmissão de sons e imagens);

- Tema 4 - Equipamentos elétricos e telecomunicações (unidades temáticas: aparelhos elétricos, motores elétricos, geradores, emissores e receptores);

- Tema 5 - Matéria e radiação (unidades temáticas: matéria e suas propriedades, radiações e suas interações, energia nuclear e radioatividade, eletrônica e informática);

- Tema 6 - Universo, Terra e vida (unidades temáticas: Terra e sistema solar, o universo e sua origem, compreensão humana do universo).

Mas não basta apenas reformular o currículo. O processo é muito mais complexo e vai além dessa etapa. Apesar dessas reformulações serem importantes e desejáveis, "estudar o currículo nunca é estudar a realidade escolar" (CARVALHO \& VANNUCCHI, 1996, p.3). Há então dois níveis: "o nível das ideias, dos princípios gerais, da teoria educativa e o nível da tradução operacional, da prática pedagógica, da ação em sala de aula" (ibidem). Temos ciência de que, por diversos motivos, muitos professores não vão considerar as orientações contidas nesses Parâmetros Curriculares, ou, então, apresentar uma postura de descrédito ou desinteresse. Porém,

[...] menosprezar o poder do currículo escrito oficial sobre o cotidiano das escolas significa desconsiderar toda uma série de mecanismos de difusão, simbólicos e materiais, desencadeados por uma reforma curricular, com o intuito de produzir uma retórica favorável às mudanças projetadas e orientar a produção do conhecimento escolar. (LOPES, 2002, p. 387).

Logicamente que não basta simplesmente agregar conteúdos à grade curricular de 
física do ensino médio. O que se pretende com eles? Para que e para quem se ensina física?

Salientando ainda que, "nas últimas décadas muitos dos países mais desenvolvidos do mundo têm mudado de uma economia industrial para uma economia do conhecimento, baseada na criação de conhecimento, informação e inovação.” (SAWYER, 2006, p. 41).

No caso específico da física no ensino médio, alerta-se que o ensino dessa disciplina destina-se principalmente àqueles que terão na escola uma das poucas oportunidades de acesso formal a esse saber e que tampouco serão físicos (talvez, nem sequer terão acesso ao ensino superior, independente do curso). Assim, "há de se reconhecer, então, dois aspectos do ensino da Física na escola: a Física como cultura e como possibilidade de compreensão do mundo." (BRASIL, 2006, p.53). Defendemos que,

Um fator determinante no encaminhamento de um jovem para o encantamento com o conhecimento, para o estabelecimento de um diálogo inteligente com o mundo, para a problematização consciente de temas e saberes, é a vivência de um ambiente escolar e cultural rico e estimulador, que possibilite o desabrochar da curiosidade epistemológica. (ZANETIC, 2005, p. 21. Grifo nosso).

Esse "encantamento com o conhecimento", num primeiro momento, pode caracterizarse um tanto simplório e sem profundidade, ou seja, uma curiosidade ingênua, mas ainda sim de extrema importância no processo de aprendizagem, uma vez que ela pode tornar-se uma curiosidade epistemológica através de um processo investigativo e questionador do indivíduo. Segundo o educador Paulo Freire (2007), a própria consciência crítica é indicação da presença da curiosidade epistemológica, componente resultante da transformação da curiosidade ingênua ao se criticizar.

A curiosidade como inquietação indagadora, como inclinação ao
desvelamento de algo, como pergunta verbalizada ou não, como procura de
esclarecimento, como sinal de atenção que sugere alerta faz parte integrante
do fenômeno vital. Não haveria criatividade sem a curiosidade que nos move
e que nos põe pacientemente impacientes diante do mundo que não fizemos,
acrescentando a ele algo que fazemos. (FREIRE, 2007, p. 32).

Portanto, assegurar o desenvolvimento de uma competência investigativa e a formação ou resgate de um espírito questionador, que permita ao educando (re)descobrir o mundo em que se habita e melhor conhecer e dialogar com as construções e saberes humanos, resultaria em um dos principais objetivos da física no ensino médio, pois "como professor devo saber que sem a curiosidade que me move, que me inquieta, que me insere na busca, não aprendo nem ensino." (FREIRE, 2007, p.85, grifo do autor). Além disso, uma vez que a curiosidade foi estimulada/aflorada, geram-se possibilidades do sujeito se lançar criticamente em busca de 
mais informações sobre aquele assunto que o motivou, "assim, saber melhor o que já sei às vezes implica saber o que antes não era possível saber. Daí a importância de educar a curiosidade, a qual se constitui, cresce e se aperfeiçoa no próprio exercício.” (FREIRE, 2006, p. 19).

Mas, enfim, como prover situações que tenham potencial de gerar essa competência investigativa e espírito questionador, esse movimento entre a curiosidade ingênua e a epistemológica? Certamente não deve ser feito apenas de modo pragmático, como aplicação imediata, mas expandindo a compreensão do mundo, a fim de propor novas questões problemas e desafios e, talvez, encontrar soluções (ZANETIC, 2005, 2006; DELIZOICOV, 2005). Conforme veremos a seguir, os "problemas", mais especificamente, a noção de problematização, ganha maior destaque no ensino de física, uma vez se constitui em ator principal na construção do conhecimento e formação do espírito científico (BACHELARD, 1977; FREIRE, 1977; DELIZOICOV, 2005).

\section{4 - Problematização e contextualização no ensino de física.}

Em sua maioria, os cursos de ciências da educação básica tratam de uma ciência estática e completa, cuja função do estudante gira basicamente na reprodução de procedimentos e algoritmos, memorização e aplicação de fórmulas e conceitos técnicocientíficos. Isso pode ser verificado com maior clareza quando nos deparamos com o processo de resolução linear de problemas do tipo "lápis e papel" explicados pelo professor como algo que se sabe fazer, cuja solução se conhece e que não gera dúvidas, os alunos, por sua vez, "podem aprender tal solução e repeti-la ante situações idênticas, mas não aprendem a abordar um verdadeiro problema e qualquer mudança lhes impõe dificuldades insuperáveis, provocando o abandono". (GIL-PEREZ et al, 1992, p.11). Essencialmente, um "verdadeiro problema" é definido como uma situação, qualitativa ou não, ante a qual se está inicialmente perdido, ou seja, que pede uma solução para a qual o indivíduo envolvido nesse processo não conhece os meios ou caminhos para obtê-la, ele não é levado à solução (se ocorrer) de modo imediato ou automático (Krulik \& Rudnick, 1980, apud GIL-PEREZ et al, 1992; PEDUZZI, 1997).

De maneira geral, o que se verifica no ensino de física não é a busca por resolução de “problemas verdadeiros”, mas sim, exercícios de aplicação da teoria, calcados na busca de uma conexão entre dados e incógnitas. Todavia, essa prática não pode ser marginalizada e 
colocada como irrelevante, pelo contrário, é através dela que o estudante desenvolve e consolida habilidades, tal prática possibilita "familiarizar os estudantes com uma nova linguagem, com procedimentos matemáticos e com formas de raciocínio típicos da profissão, como, por exemplo, a análise dimensional e aplicação de soluções gerais a casos limites." (ZYLBERSZTAJN, 1998). Numa perspectiva Kuhniana (KUHN, 2007), Zylbersztajn destaca ainda que:

\begin{abstract}
Ao resolver os problemas exemplares, ou seja, paradigmáticos, eles aprendem a aplicar as versões apropriadas das leis físicas (generalizações simbólicas) a contextos específicos, um processo através do qual novos problemas passam a ser encarados como casos análogos àqueles já encontrados previamente. Esta habilidade de perceber uma variedade de situações sob uma mesma "gestalt" é o que de mais importante um aluno adquire ao trabalhar os problemas exemplares já que, desta forma, sua percepção (bem como seu discurso e suas ações) vai sendo moldada segundo a maneira de ver que é peculiar a uma comunidade científica. (ZYLBERSZTAJN, 1998, p. 10).
\end{abstract}

No entanto, esse fato nem sempre fica claro para o aluno, que, muitas vezes, considera enfadonho, cansativo e sem propósito a repetição continuada de certas práticas (PEDUZZI, 1997). Somado a isso, "poucas escolas ensinam os alunos a criar conhecimento; em vez disso, os alunos são ensinados de que o conhecimento é estático e completo, tornando-os especialistas em consumir o conhecimento em vez de produzir conhecimento" (SAWYER, 2006, p. 42).

Como bem aponta Paulo Freire (2007, pp. 56-57), o ensino que "“castra' a curiosidade do educando em nome da eficácia da memorização mecânica do ensino dos conteúdos, tolhe a liberdade do educando, a sua capacidade de aventurar-se. Não forma, domestica.”. Em uma espécie de antídoto a essa postura, Paulo Freire propõe uma educação problematizadora, especialmente por meio do diálogo entre o educador e o educando na tentativa de despertar uma reflexão, um questionamento efetivo acerca do conteúdo e saberes que os mediatiza, do mundo ao seu redor, e não a de dissertar sobre ele, de dá-lo, de estendê-lo, de entregá-lo, como se tratasse de algo já feito, elaborado, acabado, terminado (FREIRE, 1977). Para o ensino de ciências, de maneira geral, tal problematização torna-se de vital importância no processo de ensino-aprendizagem, visto que:

E seja o que for que digam, na vida científica, os problemas não se apresentam por si mesmos. É precisamente esse sentido do problema que dá a característica do genuíno espírito científico. Para um espírito científico, todo conhecimento é resposta a uma questão. Se não houve questão, não pode haver conhecimento científico. Nada ocorre por si mesmo. Nada é 
dado. Tudo é construído. (Bachelard, 1977, apud DELIZOICOV, 2005, p. 128).

$\mathrm{Na}$ verdade, nenhum pensador, como nenhum cientista, elaborou seu pensamento ou sistematizou seu saber científico sem ter sido problematizado, desafiado. Embora isso não signifique que todo homem desafiado se torne filósofo ou cientista, significa, sim, que o desafio é fundamental à constituição do saber. (FREIRE, 1977, p. 54).

Delizoicov (1991 e 2005), após reflexões e estudos sobre a transposição da concepção freiriana da educação para o ensino de ciências, bem como inspirado em outros pensadores e obras, coloca a problematização como eixo estruturador da atividade docente auxiliado através do que se denominou de momentos pedagógicos, quais sejam: a) problematização inicial; b) organização do conhecimento; c) aplicação do conhecimento.

A problematização inicial é o momento de apresentação do problema, que sempre está relacionado a uma situação instigante e significativa para os alunos. Nessa etapa um dos objetivos principais é guiar os estudantes na percepção de que a atividade não se resume a resolução de uma questão óbvia e, assim, levá-los a detectarem as limitações de seus conhecimentos empíricos, adquiridos das vivências cotidianas (cultura primeira), de modo a sentirem necessidade de adquirir novos conceitos ou aprofundarem sua cultura científica, com intuito de garantirem os requisitos necessários para o enfrentamento do problema proposto. Por sua vez, a organização do conhecimento visa à tomada de consciência do problema e dos conhecimentos necessários para solucioná-lo. Nesta etapa, é necessário o surgimento do confronto entre os conhecimentos intuitivos e prévios do aluno e os conhecimentos especializados do professor. Os alunos passarão a ter contato com novos conceitos, é importante que eles possam explorá-los com cuidado e, ao final, eles possam sistematizá-los em outras atividades, de síntese do conteúdo, por exemplo. Já a aplicação do conhecimento é momento de avaliar a amplitude e alcance dos novos conhecimentos apropriados pelos estudantes na resolução de novas situações-problemas. Com isso, os alunos começam a ter um segundo nível de sistematização do conhecimento, buscando estendê-lo para outras questões e situações de mesma natureza. Isso é importante, pois a aplicação do conhecimento deixa de ser um exemplo do conteúdo ensinado e passa a ser uma ferramenta de pensamento para reflexão (ANGOTTI \& DELIZOICOV, 2002; DELIZOICOV, 1991 e 2005).

Não se deve confundir aqui a problematização com a Aprendizagem Baseada em Problemas (ABP), do inglês Problem-based learning (PBL), comumente utilizada na área biomédica (ALLEN, DONHAM \& BERNHARDT, 2011; NEVILLE, 2009; GOMES et al., 
2009; SAVERY, 2006; NEWMAN, 2005). Apesar de apresentarem pontos em comum, como trabalhar com problemas para fomentar o processo de ensino e aprendizagem, rompendo com as formas tradicionais de ensino e estimulando, assim, a gestão participativa dos alunos na construção do conhecimento, elas se diferem como um todo tendo em vista principalmente seus métodos de ensino e de formação (BERBEL, 1998; CYRINO \& TORALLES-PEREIRA, 2004). Enquanto a problematização pode ser pontual e centrada numa disciplina, a "Aprendizagem baseada em problemas deve ser a base pedagógica do currículo e não parte de um currículo didático" (SAVERY, 2006, p. 14, tradução nossa).

A ABP é uma proposta que passa a direcionar toda a organização curricular de um curso, havendo necessidade de maior movimento do corpo docente, administrativo e acadêmico da instituição para desenvolvê-la. Sua utilização demanda alterações estruturais e trabalho integrado dos diversos departamentos e disciplinas que compõem o currículo dos cursos. (CYRINO \& TORALLES-PEREIRA, 2004, p. 785).

Fundamental para o sucesso da abordagem [PBL] é a seleção de problemas mal-estruturados (muitas vezes interdisciplinares) e um tutor que orienta o processo de aprendizagem e conduz um interrogatório minucioso na conclusão da experiência de aprendizagem. (SAVERY, 2006, p. 12. Tradução nossa).

Uma das formas possíveis e recorrentes na literatura da área para auxiliar o processo de problematização no ensino de ciências, bem como levar para a sala de aula discussões (explicitas ou implicitas) do mundo ao nosso redor, da cultura e da história humana, surge através de um outro processo, denominado de contextualização (FERNANDES \& MARQUES, 2012; KATO \& KAWASAKI, 2011; NIKITINA, 2006; RICARDO, 2005; SILVA, 2007; BRASIL, 2006). Conforme orienta o próprio Ministério da Educação do Brasil,

A contextualização como recurso didático serve para problematizar a realidade vivida pelo aluno, extraí-la do seu contexto e projetá-la para a análise. $\mathrm{Ou}$ seja, consiste em elaborar uma representação do mundo para melhor compreendê-lo. Essa é uma competência crítico-analítica e não se reduz à mera utilização pragmática do conhecimento científico. (BRASIL, 2006, p. 51).

Segundo o educador Paulo Freire,

O que importa fundamentalmente à educação, contudo, como uma autêntica situação gnosiológica, é a problematização do mundo do trabalho, das obras, dos produtos, das ideias, das convicções, das aspirações, dos mitos, da arte, da ciência, enfim, o mundo da cultura e da história, que, resultando das relações homem-mundo, condiciona os próprios homens, seus criadores. Colocar este mundo humano como problema para os homens significa propor-lhes que "ad-mirem", criticamente, numa operação totalizada, sua 
ação e a de outros sôbre o mundo. Significa "re-ad-mirá-la", através da "admiração" da "ad-miração" anterior, que pode ter sido feita ou realizada de forma ingênua, não totalizada. Desta maneira, na "ad-miração" do mundo "admirado", os homens tornam conhecimento da forma como estavam conhecendo, e assim reconhecem a necessidade de conhecer melhor. (FREIRE, 1977, pp. 82-84. Grifo nosso).

Dependendo do tema ou unidade temática que se deseja trabalhar, além da própria realidade escolar, existe uma vasta gama de "meios", ou melhor, de contextos imersos em cenários de várias ordens: social, cultural, científico, histórico, ambiental, biológico, cotidiano, tecnológico, dentre outros. Essas "realidades" podem ser tomadas como base na formulação de problemas e emersão de conhecimentos, dentro de um processo de ensino e aprendizagem contextualizado com vistas ao resgate ou à formação de um espírito questionador, uma "ad-miração" do mundo "admirado" em que os homens tomam conhecimento da forma como estavam conhecendo, e, assim, reconhecem a necessidade de conhecer melhor.

Em contrapartida, a própria noção de contextualização apresenta diferentes vertentes, entre as quais parece não haver um consenso em relação ao que, de fato, seja um ensino de física contextualizado, ou, por outro lado, algumas têm uma visão simplista e acrítica sobre a contextualização no processo de ensino e aprendizagem (RICARDO, 2005, 2010; LOPES, 2002) conforme discutido a seguir.

\section{5 - As múltiplas faces da contextualização}

No cenário educacional, a noção de contextualização carrega consigo múltiplas faces (WARTHA, SILVA \& BEJARANO, 2013; FERNANDES \& MARQUES, 2012; KATO \& KAWASAKI, 2011; RICARDO, 2010; LOPES, 2002). No dicionário Caldas Aulete ${ }^{6}$, o substantivo "contextualização" (con.tex.tu:a.li.za.ção), significa: 1. Ação ou resultado de contextualizar, colocar no contexto correspondente. 2. Vinculação do conhecimento à sua origem e aplicação. Por sua vez, o verbo "contextualizar” (con.tex.tu:a.li.zar) significa:

1. Apresentar as circunstâncias e o contexto de (fato, ideia, afirmação, comportamento etc.): $\mathrm{O}$ jornalista contextualizou suas declarações. 2. Ling. Apresentar frase ou texto onde (determinada palavra ou expressão) se encontra: Contextualize a palavra 'rico' para ver se é adjetivo ou substantivo. 3. Entender, analisar ou interpretar o significado de algo levando em conta o contexto, as circunstâncias de ocorrência. (AULETE, 2014, versão online). Grifo do autor.

\footnotetext{
${ }^{\mathbf{6}}$ Versão digital, disponível em: http://aulete.uol.com.br. Acesso em 02 de Fevereiro de 2014. 56
} 
Para Machado (2005), ao invés de contextualização, o termo mais adequado no âmbito educacional seria contextuação, onde, segundo o autor:

[...] contextuar é uma estratégia fundamental para a construção de significações. À medida que incorpora relações tacitamente percebidas, a contextuação enriquece os canais de comunicação entre a bagagem cultural, quase sempre essencialmente tácita, e as formas explícitas ou explicitáveis de manifestação do conhecimento. (ibidem, p. 53).

Em pesquisa sobre as concepções de contextualização do ensino em documentos curriculares oficiais e de professores de ciências, Kato \& Kawasaki (2011) identificam onze termos, a saber: realidade, vida, vivência, mundo, cotidiano, trabalho, cidadania, contexto social, contexto histórico e cultural, conhecimentos prévios do aluno e disciplinas escolares. Estes termos foram agrupados em cinco categorias de análise das concepções de contextualização e sintetizados em um quadro conforme apresentado a seguir (Tabela 1). Verifica-se, por exemplo, que as concepções de contextualização do ensino relacionadas ao cotidiano do aluno, a questões de ordem disciplinar e ao contexto histórico, social e cultural, são aquelas que predominam entre os sujeitos da pesquisa.

Tabela 1 - Categorias de análise das concepções de contextualização do ensino, contextos de significação e de ocorrência destas concepções. Fonte: Kato \& Kawasaki (2011, p. 45).

\begin{tabular}{|c|c|c|c|}
\hline $\begin{array}{l}\text { Categorias de } \\
\text { análise }\end{array}$ & Concepções & $\begin{array}{l}\text { Contextos de } \\
\text { significação }\end{array}$ & $\begin{array}{l}\text { Documentos ou } \\
\text { professores }\end{array}$ \\
\hline \multirow[t]{2}{*}{$\begin{array}{l}\text { 1) Cotidiano do } \\
\text { aluno }\end{array}$} & $\begin{array}{l}\text { Buscar relações com as } \\
\text { experiências pessoais e sociais } \\
\text { do aluno, a realidade do aluno } \\
\text { e a cidadania. }\end{array}$ & $\begin{array}{l}\text { Cotidiano do } \\
\text { aluno }\end{array}$ & $\begin{array}{c}\text { DCNEM/PCNEM/ } \\
\text { PCEB/PCNEF/ } \\
\text { PCEC/ MRCC } \\
\text { Professores }\end{array}$ \\
\hline & $\begin{array}{l}\text { Buscar relações com o mundo } \\
\text { do trabalho. }\end{array}$ & $\begin{array}{l}\text { Mundo do } \\
\text { trabalho }\end{array}$ & DCNEM \\
\hline $\begin{array}{l}\text { 2) Disciplina(s) } \\
\text { escolar(es) }\end{array}$ & $\begin{array}{l}\text { Buscar relações com outras } \\
\text { disciplinas (multi, trans ou } \\
\text { interdisciplinaridade). }\end{array}$ & $\begin{array}{l}\text { Outras } \\
\text { disciplinas } \\
\text { escolares }\end{array}$ & $\begin{array}{c}\text { DCNEM/PCNEM/ } \\
\text { PCNEF/PCEC } \\
\text { Professores }\end{array}$ \\
\hline \multirow[b]{2}{*}{ 3) Ciência } & $\begin{array}{l}\text { Buscar relações com a ciência, } \\
\text { enquanto produto e processo. }\end{array}$ & $\begin{array}{l}\text { Universo da } \\
\text { ciência }\end{array}$ & PCNEM/PCEC \\
\hline & $\begin{array}{l}\text { Buscar relações com as } \\
\text { ciências naturais, em especial, } \\
\text { as ciências biológicas (as } \\
\text { teorias evolutivas). }\end{array}$ & $\begin{array}{c}\text { Teorias gerais } \\
\text { da Biologia e } \\
\text { da ciência }\end{array}$ & PCEB \\
\hline \multirow[t]{2}{*}{ 4) Ensino } & $\begin{array}{l}\text { Buscar relações entre } \\
\text { conhecimento científico e } \\
\text { conhecimento escolar. }\end{array}$ & $\begin{array}{l}\text { Conhecimento } \\
\text { científico }\end{array}$ & PCNEM \\
\hline & Buscar problematizar e situar o & Diversas & PCNEF/PCEC/ \\
\hline
\end{tabular}




\begin{tabular}{|c|c|c|c|}
\hline & $\begin{array}{l}\text { conhecimento escolar em } \\
\text { relação a outras formas de } \\
\text { conhecimento. }\end{array}$ & $\begin{array}{l}\text { formas de } \\
\text { conhecimento } \\
\text { em diferentes } \\
\text { contextos }\end{array}$ & MRCC \\
\hline \multirow{3}{*}{$\begin{array}{l}\text { 5) Contexto } \\
\text { histórico, social e } \\
\text { cultural }\end{array}$} & $\begin{array}{l}\text { Buscar relações com elementos } \\
\text { da cultura. }\end{array}$ & $\begin{array}{l}\text { Cultura } \\
\text { brasileira e } \\
\text { mundial }\end{array}$ & $\begin{array}{c}\text { PCNEM/PCNEF/ } \\
\text { PCEC } \\
\text { Professores }\end{array}$ \\
\hline & $\begin{array}{l}\text { Buscar relações com a história } \\
\text { da ciência. }\end{array}$ & $\begin{array}{l}\text { Contexto } \\
\text { histórico e } \\
\text { social }\end{array}$ & PCNEM/PCEC \\
\hline & Buscar relações CTS. & $\begin{array}{l}\text { Ciência, } \\
\text { tecnologia e } \\
\text { sociedade. }\end{array}$ & $\begin{array}{c}\text { PCNEM/PCNEF/ } \\
\text { PCEC } \\
\text { Professores }\end{array}$ \\
\hline
\end{tabular}

DCNEM (1998) - Diretrizes Curriculares Nacionais para o Ensino Médio.

PCNEM (1999) - Parâmetros Curriculares Nacionais para o Ensino Médio.

PCEB (1988) - Proposta Curricular para o Ensino de Biologia.

PCNEF (1998) - Parâmetros Curriculares Nacionais para o Ensino Fundamental.

PCEC (1991) - Proposta Curricular para o Ensino de Ciências e Programas de Saúde.

MRCC (1992) - Movimento de Reorientação Curricular - Ciências.

De acordo com Silva (2007, p. 10), a contextualização no ensino é comumente defendida como 'um 'meio' de possibilitar ao aluno uma educação para a cidadania concomitante à aprendizagem significativa de conteúdos".

De acordo com os documentos oficiais do Ministério da Educação do Brasil (BRASIL, 1998), a noção de contextualização é respaldada pelo conceito inglês "situated learning" (aprendizagem situada), a qual, por sua vez, apresenta quatro grandes premissas que orientam o desenvolvimento de atividades em sala de aula, a saber:

(1) a aprendizagem é fundamentada nas ações de situações do cotidiano, (2) o conhecimento é adquirido situacionalmente e transferido apenas para situações semelhantes, (3) a aprendizagem é o resultado de um processo social que abrange formas de pensar, perceber, resolver problemas, e interagir, além do conhecimento declarativo e processual, e (4) a aprendizagem não está separada do mundo da ação, mas existe em ambientes robustos, complexos, sociais, firmada por atores, ações e situações. (STEIN, 1998, p.2).

As Diretrizes Curriculares Nacionais para o Ensino Médio (DCNEM) ressaltam ainda

que:

Contextualizar o conteúdo que se quer aprendido significa em primeiro lugar assumir que todo conhecimento envolve uma relação entre sujeito e objeto. $\mathrm{Na}$ escola fundamental ou média o conhecimento é quase sempre reproduzido das situações originais nas quais acontece sua produção. Por esta razão quase sempre o conhecimento escolar se vale de uma transposição didática para na qual a linguagem joga papel decisivo. $O$ tratamento contextualizado do conhecimento é o recurso que a escola tem para retirar o aluno da condição de espectador passivo. Se bem trabalhado permite que, ao 
longo da transposição didática, o conteúdo do ensino provoque aprendizagens significativas que mobilizam o aluno e estabeleçam entre ele e o objeto do conhecimento uma relação de reciprocidade. A contextualização evoca por isto áreas, âmbitos ou dimensões presentes na vida pessoal, social e cultural, e mobiliza competências cognitivas já adquiridas. As dimensões de vida ou contextos valorizados explicitamente pela LDB são o trabalho e a cidadania. As competências estão indicadas quando a lei prevê um ensino que facilite a ponte entre a teoria e a prática. (BRASIL, 1998, p. 42).

Apesar deste documento, em especial, não entrar em detalhes sobre o que, de fato, está se considerando como uma aprendizagem significativa e sobre as nuanças que permeiam a noção de transposição didática, identifica-se no trecho citado acima uma preocupação em explorar as concepções prévias dos estudantes através de um tratamento contextualizado do conhecimento, onde questões que envolvem a vida pessoal, social e cultural do educando devem ser mobilizados.

Dentre as estratégias indicadas pelos Parâmetros Curriculares para mobilizar competências cognitivas já adquiridas pelos estudantes, evocando, assim, áreas, âmbitos ou dimensões presentes na sua vida pessoal, social e cultural, estão o uso da língua e seus códigos no contexto das diferentes práticas humanas (familiares, política, científica, etc.); conhecer o corpo humano e sua relação com o meio; ter no trabalho uma forma de compreensão das produções de riqueza e das interações do ser humano com a natureza e com o mundo social; a produção de serviços de saúde e questões sobre o meio ambiente como forma de tratar os conteúdos de biologia e gerar condutas ambientalistas responsáveis no meio ambiente imediato da escola, da vizinhança e do lugar onde se vive; a produção de bens nas áreas de mecânica e eletricidade para tratar de conteúdos de física e, assim, favorecer a formação profissional de técnicos dessas áreas, dentre outras (BRASIL, 1998, 2002, 2006).

Desse modo, tais diretrizes generalizam a contextualização "como recurso para tornar a aprendizagem significativa ao associá-la com experiências da vida cotidiana ou com os conhecimentos adquiridos espontaneamente" (BRASIL, 1998, p. 46). Entretanto, alerta-se para não se cair na banalização, aprisionando os conteúdos escolares ao espontaneísmo e na cotidianidade. Ainda neste documento, defende-se a necessidade de se considerar os fundamentos epistemológicos e psicológicos, segundo os quais o indivíduo não inicia a aprendizagem escolar formal do zero. O estudante carrega consigo uma bagagem formada por conceitos já adquiridos espontaneamente, em geral enraizados de afetos e valores por resultarem de experiências pessoais. A abstração e generalização desses conhecimentos são efetivadas ao longo do desenvolvimento do indivíduo, numa tarefa árdua e prolongada, difícil 
de formalizar ou explicar em palavras, principalmente por não serem conscientes nem deliberadas.

Em pesquisa sobre as noções de competências, interdisciplinaridade e contextualização presentes nas Diretrizes Curriculares Nacionais para o Ensino Médio e nos Parâmetros Curriculares Nacionais (DCNEM e PCN), além de outros pressupostos contidos nesses documentos, Ricardo (2005, p.71) identifica na fala de alguns autores dos Parâmetros Curriculares alertas para que não se permaneça na cotidianidade, de aplicação imediata, mas para que se busque dar sentido ao que se ensina, a saber:

A contextualização foi lida, pelo menos entre nós elaboradores dos Parâmetros, da seguinte forma: se eu pensar a contextualização só como aplicação eu estou empobrecendo o significado da contextualização. Significado de contextualização é trabalhar dentro de um texto, trabalhar com o texto. O que é um texto? Texto é uma situação que faz sentido, tem começo meio e fim, tem uma lógica interna. Então, a leitura de contextualização é trabalhar dentro de situações em que o aluno veja sentido. (ibidem, entrevistado A7).

Nós enxergamos a contextualização como enraizar significados num texto. Então, para nós a contextualização não tem só a dimensão do como se aplica isso no contexto da vida real, até porque a gente sabe que na ciência e no ensino médio tem algumas coisas que se você levasse a "ferro e fogo" só essa idéia da contextualização como aplicação no mundo real você corria o risco dos estereótipos e corria o risco de ter coisas que você não consegue essa contextualização. Então, nós, do mesmo jeito que não entramos na armadilha do temático, não entramos na armadilha dessa contextualização vista estritamente como uma aplicação imediata. (ibidem, entrevistado A6).

A contextualização para nós não é simplesmente dar exemplos de fatos, de materiais, que o aluno tem contato, não é só uma exemplificação, uma ilustração. É o contexto para o aluno entender a realidade em que ele vive e até a que ele não vive necessariamente, imediatamente, mas que ele como cidadão do mundo globalizado também tem que compreender e, mais que compreender, tem que poder avaliar e tomar uma decisão. (ibidem, entrevistado A5).

Em outro documento, nas orientações educacionais complementares aos Parâmetros Curriculares Nacionais (PCN+), uma espécie de complemento ou "atualização" dos PCN, o MEC afirma ainda que,

[...] em termos gerais, a contextualização no ensino de ciências abarca competências de inserção da ciência e de suas tecnologias em um processo histórico, social e cultural e o reconhecimento e discussão de aspectos práticos e éticos da ciência no mundo contemporâneo. (BRASIL, 2002, p.31).

Assim, são apresentados quatro pontos envolvendo a contextualização numa 
perspectiva sociocultural, a saber:

$i$. Ciência e tecnologia na história: compreender o conhecimento científico e o tecnológico como resultados de uma construção humana, inseridos em um processo histórico social;

ii. Ciência e tecnologia na cultura contemporânea: compreender a ciência e a tecnologia como partes integrantes da cultura humana contemporânea;

iii. Ciência e tecnologia na atualidade: reconhecer e avaliar o desenvolvimento tecnológico contemporâneo, suas relações com as ciências, seu papel na vida humana, sua presença no mundo cotidiano e seus impactos na vida social;

iv. Ciência e tecnologia, ética e cidadania: reconhecer e avaliar o caráter ético do conhecimento científico e tecnológico e utilizar esses conhecimentos no exercício da cidadania.

Dessa forma, o MEC determina que Ciência e Tecnologia sejam tratadas de tal modo que o discente possa compreendê-las, reconhecê-las e avalia-las imersas em vários cenários, do social-histórico ao ético-social. É possível identificar uma preocupação em possibilitar ao educando uma compreensão atualizada do mundo que o cerca enquanto ser social, mundo este onde as relações entre ciência e tecnologia estão cada vez mais entrelaçadas. Assim, como bem aponta Ricardo (2005, p.71), a "ideia da tomada de decisão fundamentada cientificamente é um dos grandes objetivos do ensino das disciplinas da área das Ciências da Natureza e passa a dar sentido também para a proposição da tecnologia como objeto de ensino associado às disciplinas.”.

Reflexo de discussões e debates, em 2006 foram publicadas pelo governo federal do Brasil novas diretrizes educacionais (BRASIL, 2006). Novamente, reforça-se que "não se pretende com a contextualização partir do que o aluno já sabe e chegar ao conhecimento científico, pois esse não é apenas polimento do senso comum", mas sim, "o que se pretende é partir da reflexão crítica ao senso comum e proporcionar alternativas para que o aluno sinta a necessidade de buscar e compreender esse novo conhecimento.” (ibidem, p. 51). Tal documento, assim como seus predecessores, coloca a contextualização como princípio condutor da organização curricular para as disciplinas de ciências naturais e matemática.

Por fim, Lopes (2002) alerta para um discurso híbrido, fruto de uma recontextualização, presente nos Parâmetros Curriculares Nacionais para o Ensino Médio (PCNEM). Segundo a autora, "o conceito de contextualização foi desenvolvido pelo MEC por apropriação de múltiplos discursos curriculares, nacionais e internacionais, oriundos de contextos acadêmicos, oficiais e das agências multilaterais.” (LOPES, 2002, p. 390. Grifo 
nosso). Tal discurso teria por finalidade a inserção social no mundo produtivo. Dentre os resultados de seu trabalho, identificam-se três interpretações para a noção de "contexto" nas diretrizes curriculares (ensino médio): trabalho; cidadania; vida pessoal, cotidiana e convivência. Segundo a autora, "o contexto que efetivamente é apresentado como comum a todas as disciplinas é o do mundo produtivo e das exigências do mercado de trabalho da era pós-industrial.” (ibidem, p. 1)..

\subsection{1 - Noção de contextualização adotado e questões iniciais da tese}

Apesar das múltiplas faces identificadas para o termo contextualização, conforme discutido anteriormente, não se pode considerar todas as noções como equivalentes, pois:

Se assim fossem, estaríamos valorizando uma visão relativista da contextualização. Ou seja, quando alguns dos elaboradores destacam que a contextualização é a aplicação prática de um determinado conhecimento no cotidiano está reduzindo o papel da contextualização, pois parece reduzir dimensões culturais, sociais e reflexivas que a apropriação do conhecimento possibilita. Igualmente, entender que contextualizar o conhecimento é ficar aderido a situações vinculadas à localidade dos estudantes é outro limite na forma de compreender o papel da contextualização no ensino. Embora, essas percepções sejam entendidas como formas de contextualizar o conhecimento elas apresentam limitações comparadas a outras em que extrapolam a aplicação prática de um determinado conceito em atividades práticas e as que ficam aderidas a situações locais. (FERNANDES \& MARQUES, 2012, p. 525).

Faz-se necessário a adoção de um modelo de contextualização que, além de possibilitar explorar situações vinculadas à localidade dos estudantes, também seja capaz de oferecer condições nas quais não seja excluída a presença do conteúdo conceitual, que permita explorar também questões de ordem social, histórica, cultural, científica, dentre outras, identificadas em uma dada "realidade" e que fazem parte do conhecimento humano como um todo, imerso em uma construção coletiva.

Para isso, podemos pensar e compreender a contextualização analisando-a somente ao término de um processo (RICARDO, 2010), o qual deve passar necessariamente por uma problematização e uma modelização do conhecimento humano sobre uma situação presente em uma dada "realidade", contida numa determinada prática social de referência (MARTINAND, 1981). “As principais práticas de referência para introdução às ciências e tecnologias são os diferentes tipos de produções industriais ou artesanais, as pesquisas científicas, as práticas domésticas, ideológicas e políticas" (MARTINAND, 1981, p. 154, grifo nosso). Desse modo, as atividades sociais diversas, contanto que sejam reconhecidas 62 
como tendo um papel ou uma função na sociedade, formais ou não, como música, corte e costura, atividades acadêmicas, culturais, limpeza, construção civil, etc., servem de referência para a atividade científica escolar, que as examina e questiona seus métodos, problemas e saberes correspondentes. De acordo com Martinand, idealizador desse termo, trata-se de:

[...] levar em consideração as práticas em todos os aspectos, incluindo seus componentes de saberes, discursivos ou outros, explícitos ou implícitos, individuais ou coletivos; o significado e a estrutura dos saberes, inclusive dos conceitos centrais da prática, mesmo que os objetos pareçam os mesmos. (MARTINAND, 2003, p. 128. Tradução nossa).

Assim, leva-se em conta na prática escolar não só o conhecimento envolvido, mas os objetos, instrumentos, temas e tarefas, contextos e papéis sociais (MARTINAND, 1981, 2003; ASTOLFI \& DELEVAY, 2001). Como bem reconhece Zanardi (2013, p. 55), essa estratégia metodológica "exige que os professores aventurem-se fora de suas disciplinas e estejam dispostos a trabalhar com problemas que ultrapassam seus conhecimentos específicos.". Importante ressaltar que "referência" não tem aqui o sentido daquilo que se toma como parâmetro por sua qualidade, eficiência etc., mas sim enquanto alusão a pessoas, coisas, opiniões, texto etc., independente da sua qualidade e/ou eficiência.

Nesse cenário, a contextualização inicia-se por meio da problematização (compreendida nos moldes anteriormente discutidos) e de uma determinada prática social de referência imersa numa dada realidade. A problematização inicial dessa prática assume papel fundamental e tem como principal finalidade gerar nos estudantes a necessidade de apropriação de um conhecimento que eles ainda não possuem ou não dominam para solução das questões e tarefas apresentadas. Isso é de suma importância, pois, na maioria dos casos, parece que se ensinam respostas para problemas que não foram formulados e/ou não são encontrados pelos alunos em sua história pessoal, cultural e social. (POPPER, 2013; MEIRIEU, 1998). Já a modelização, remete a dimensão disciplinar de uma dada sequência didática e envolve idealizações, aproximações e seleção de variáveis relevantes, objetivando a representação do problema de maneira simplificada, seja por meio de representações pictóricas, gráficas, experimentais ou expressões matemáticas, de tal modo a permitir determinar, por exemplo, as relações físicas e restrições necessárias, mesmo que não sejam diretamente observadas (KARAN, 2012; GRECA \& SANTOS, 2005). Todo esse processo, ou noção de contextualização, é, então, sintetizado na Figura 1. 


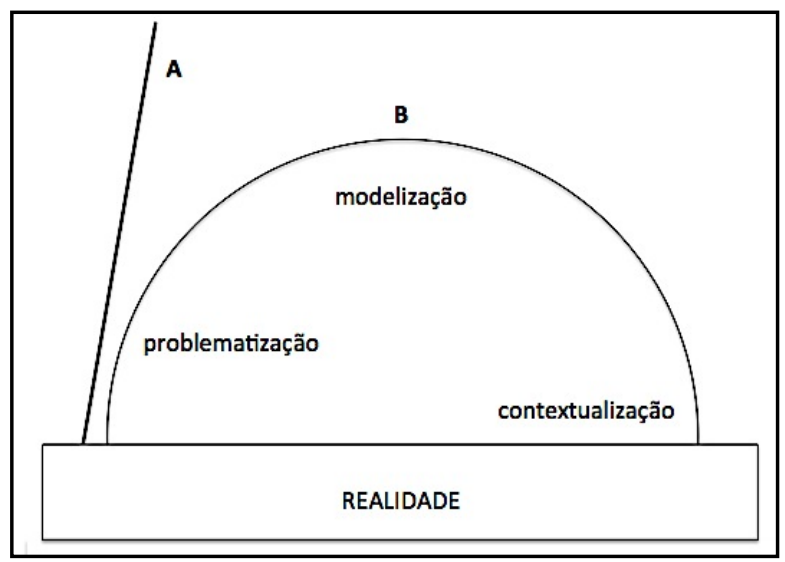

Figura 1 - Processo de contextualização em um cenário de aprendizagem específico. Fonte: Ricardo (2010, p. 43).

De acordo com esse esquema, a contextualização dar-se-á de maneira efetiva quando passar necessariamente por uma problematização e modelização, retornando para uma dada realidade ou situação que partiu (curva B). Do contrário, curva A, os contextos e questões apresentados inicialmente servirão apenas como mera ilustração ou exemplo de uma dada realidade, mas sem retorno a esta, onde, possivelmente, a relação do indivíduo com os “objetos” desse cenário permanecerão inalterados (RICARDO, 2010).

A noção de contextualização que passa por um processo permeado pela problematização e uma modelização nos parecem mais adequada e pertinente, uma vez que auxilia o desenvolvimento de atividades que não reduzem a contextualização a meras ilustrações e exemplos tirados do cotidiano. Além disso, favorece a construção de um cenário de aprendizagem, com pontos de partida e chegada bem definidos. Assim, essa será a perspectiva que adotaremos no presente estudo para tratar do processo de contextualização.

Por fim, tendo em vista toda a discussão até aqui apresentada e pensando na complexidade desta última abordagem, bem como em sua maior "eficiência", nos questionamos se poderia haver "elementos" ou "indicadores" que evidenciem e clarifiquem as correlações entre os pontos de partida e os de chegada em que a contextualização se consolida, independente da realidade ou situação abordada? Ou ainda, tão importante quanto a questão anterior, existiriam "elementos" específicos que possam servir de base para fomentar a problematização e interligar os pontos de partida e de chegada de uma dada realidade ou prática social de referência, de modo a melhor analisar o processo de contextualização? Essas são questões que apontam para um primeiro delineamento do problema central desta tese.

Dessa forma, uma das questões e desafios metodológicos que levantamos diz respeito a como promover atividades didáticas que, de fato, auxiliem a realização deste processo? 64 
Quais materiais e estratégias devem ser utilizados? Mais especificamente, como desenvolver atividades ou sequencias didáticas problematizadoras que promovam a contextualização de uma determinada prática social de referência de tal modo a despertar nos estudantes o interesse e necessidade da apropriação de um conjunto de saberes que ele ainda não possui ou não domina? Além disso, como analisar essa sequência didática de tal modo que se possa avaliar o nível de contextualização intencionado e/ ou alcançado?

Assim, seguimos no capítulo 2 discutindo os recortes necessários, as questões centrais e os objetivos principais da pesquisa. 


\section{Capítulo 2 - RECORTE, QUESTÕES CENTRAIS E OBJETIVOS DA PESQUISA: O CASO DA ROBÓTICA EDUCACIONAL}

Em resumo, o homem movido pelo espírito científico deseja saber, mas para, imediatamente, melhor questionar.

Gaston Bachelard ${ }^{7}$

Nunca fui ingênuo apreciador da tecnologia: não a divinizo, de um lado, nem a diabolizo, de outro. Por isso mesmo sempre estive em paz para lidar com ela. Não tenho dúvida nenhuma do enorme potencial de estímulos e desafios à curiosidade que a tecnologia põe a serviço das crianças e dos adolescentes [...]

Paulo Freire $^{8}$

A partir do breve panorama traçado no capítulo anterior, é possível perceber o quão complexo é o processo de ensino contextualizado, envolvendo diferentes estratégias, recursos e ações políticas/administrativas. Esses cenários são constantemente analisados e alterados na busca de melhor compreender os mecanismos e processos envolvidos numa contextualização, bem como encontrar alternativas para melhorar o ensino e a aprendizagem de ciências em diferentes níveis do sistema educacional (FOUREZ, 2003; SALEM, 2012).

\footnotetext{
${ }^{7}$ In. Formação do espírito científico. Editora Contraponto, 1996, p. 21.

${ }^{8}$ In. Pedagogia da Autonomia. $36^{\text {a }}$ edição, São Paulo: Editora Paz e Terra, 2007, p. 87.
} 
Um ensino de física contextualizador e problematizado, além de envolver diferentes objetos (abstratos ou concretos) contidos em diversos cenários ou realidades, pode exigir múltiplas estratégias metodológicas e recursos didáticos-pedagógicos como, por exemplo, peças teatrais (FORATO, 2009), textos jornalísticos (MELO, 2006), softwares e tecnologias digitais (VALENTE, MAZZONE \& BARANAUSKAS, 2007; ARAUJO, VEIT \& MOREIRA, 2004; FIOLHAIS \& TRINDADE, 2003), recursos audiovisuais (ARROIO \& FARÍAS, 2011; ARROIO, 2010), obras de ficção científica (OLIVEIRA, 2011; PIASSI, 2007), dentre outros. Nessa multiplicidade de ações qual o recorte que devemos fazer? Qual recurso didático-pedagógico adotar para se investigar a contextualização no ensino de física dentro dos moldes aqui adotados?

\section{1 - Novas tecnologias no ambiente escolar e na sociedade em geral.}

[...] assim que tivermos um terminal, um terminal de computadores em cada casa, cada uma delas interligadas com grandes bibliotecas, onde cada um pode fazer qualquer pergunta, lhes sendo concedido respostas, e materiais de referência, em algo que estás interessado em aprender, desde a infância, ainda que seja idiota para outra pessoa, mas que é do teu interesse, e tu perguntas, e descobres, e podes seguir, e o podes fazer na tua própria casa, à tua própria velocidade, e à teu critério, e a seu próprio tempo. Então todos terão prazer de aprender.

Isaac Asimov ${ }^{9}$

De acordo com Kenski (2003, p. 18), “ao conjunto de conhecimento e princípios científicos que se aplicam ao planejamento, à construção e à utilização de um equipamento em um determinado tipo de atividade nós chamamos de "tecnologia"'. Com isso, a noção de tecnologia pode estar associada a objetos simples e corriqueiros, como talheres, canetas, calçados, móveis, utensílios domésticos, papel, dentre outros, uma vez que houve a necessidade de aplicação de um conjunto de saberes para produzi-los e melhora-los de tal modo a nos permitir realizar determinadas atividades de maneira cada vez mais eficiente e precisa. Também nessa perspectiva, Utges, Fernández \& Jardón (1996), destacam que a tecnologia integra o saber fazer (conhecimentos sistematizados), as coisas feitas (produtos), assim como os modos de fazer (processos) que lhe são próprios.

\footnotetext{
${ }^{9}$ Isaac Asimov durante entrevista concedida em 1988 ao jornalista Bill Moyers no programa "World of Ideas". Disponível em: http://www.youtube.com/watch?feature=player_embedded\&v=DFkLQOgbclI Acesso em $11 \mathrm{de}$ maio de 2014. 
No que tange aos produtos tecnológicos mais complexos, como é o caso das tecnologias digitais, nota-se que elas permeiam o cotidiano, independente do espaço físico, e criam necessidades de vida e convivência que não devem ser ignoradas no meio social, especialmente no espaço escolar, embora sua difusão e acesso nem sempre ocorram de modo igualitário (VALENTE, MAZZONE \& BARANAUSKAS, 2007; MARTINHO \& POMBO, 2009; AMEM \& NUNES, 2006; GIORDAN, 2006). Neste dinâmico quadro, deparamo-nos com os tablets, pendrivers, bluray, smart TVs, plataformas para programação, simulações computacionais, robótica, além da própria internet e demais recursos imersos em uma “sociedade da tecnologia" ou na "era da tecnologia” (KENSKI, 2003).

Hoje, as mudanças sociais decorrentes do surgimento das "novas tecnologias" são patentes e se apresentam em diferentes esferas da sociedade. Especialmente nos grandes centros urbanos, é praticamente impensável viver sem a presença de uma vasta gama de "artefatos tecnológicos", tais como controle de tráfego, sistema viário e sistemas de comunicação e informação, telefones, dentre outros (CARVALHO, 1997).

Somado a isso, não se pode esquecer que os estudantes de hoje (do nível básico ao universitário), em sua maioria, já estão habituados à comunicação e à informação audiovisual dinâmica e sucinta, comum na linguagem da televisão, do cinema e, principalmente, da informática. Assim, as diferentes formas e múltiplas manifestações das tecnologias ao nosso redor, além de influenciarem significativamente os modos de vida e de produção da sociedade em geral, possuem potencial para gerar novas situações de ensino e aprendizagem. Conforme destaca o Ministério da Educação do Brasil: “As tecnologias estão no passado, no presente e estarão no futuro como armas humanas de desvendamento do universo natural e social. $\underline{A}$ problemática se encontra nas formas de seus usos e não nos fins de sua criação." (BRASIL, 2000, p. 12, grifo nosso). Além disso, “conviver com todas as possibilidades que a tecnologia oferece é mais que uma necessidade, é um direito social." (ibidem).

Através do que é acessado na internet, no computador ou no tablet, do que é assistido na televisão e nos demais recursos midiáticos, as pessoas se comunicam e adquirem informação, ampliando seu conhecimento acerca das coisas e mudando seus comportamentos, desde o vestir até o falar, pensar e agir. Contudo, como bem aponta Kenski (2003, p. 25), “esse é um dos grandes desafios para a ação da escola na atualidade. Viabilizar-se como espaço crítico em relação ao uso e à apropriação dessas tecnologias de comunicação e informação.". Além disso, quando olhamos para a maioria das salas de aula, seja na educação 
básica ou superior, pública ou privada, o que se percebe é que "alunos que são nativos digitais, ou seja, que desde a sua mais tenra infância interagem com computadores, tablets, celulares, sentem-se desconfortáveis em um ambiente que replica o que ocorria há mais de um século atrás." (ZANETTI et al, 2012, p. 143).

Todavia, deve-se tomar o cuidado para que as iniciativas de levar o computador para a escola não se restrinjam ao uso de "salas de informática" em atividades "extras", sem integração direta com os saberes disciplinares (ibidem). A introdução dessas tecnologias no ensino, em particular no ensino de ciências naturais, origina uma alteração nos papéis de todos os intervenientes do processo educacional, principalmente no do professor, que assume um papel mais mediador em um ambiente construído de tal modo que desafie e motive o educando para a exploração, reflexão e descoberta, e no do aluno, na direção de aprimorar seu sentido crítico, sua capacidade de análise, de síntese, e sua autonomia (MARTINHO \& POMBO, 2009).

Tem-se aqui, portanto, dois aspectos a se considerar sobre a tecnologia no ambiente escolar. O primeiro diz respeito à formação crítica dos estudantes, conscientiza-los a respeito do consumo responsável dos objetos provenientes das novas tecnologias presentes na sociedade em geral. O segundo trata da própria utilização de alguns desses objetos enquanto recursos didático-pedagógicos, dentre os quais estão as tecnologias digitais, para fomentar o processo de ensino e aprendizagem. Com isso, questiona-se de que forma os recursos digitais podem ser utilizados durante o aprendizado para estimular o aluno a ir além das respostas prontas e, de fato, ser o autor e produtor de seu próprio conhecimento? O que mais as novas tecnologias permitem que o jeito tradicional não permite? Como a problematização do conhecimento pode ser favorecida por esses recursos de modo a melhor desenvolver o processo de contextualização?

De acordo com algumas pesquisas e autores, as tecnologias digitais se caracterizam como meios potencializadores no auxílio e na transferência ao aluno da tarefa de criar, imaginar, construir e interagir com os saberes, além de possibilitar outras estratégias metodológicas a serem utilizadas pelo professor frente às inovações tecnológicas (CÉSAR, 2013, 2009; D’ABREU et al, 2010; JUCÁ, 2011; SENA DOS ANJOS, 2008; VALENTE, MAZZONE, \& BARANAUSKAS, 2007; GIORDAN, 2006; MIRANDA JUNIOR, 2005, NOGUEIRA et al, 2000; PAPERT, 2008). 
Como bem aponta Papert (2008), as tecnologias digitais e suas múltiplas manifestações abrem oportunidades sem precedentes para promover a qualidade do ambiente de aprendizagem, "entendido como todo o conjunto de condições que contribuem para moldar a aprendizagem no trabalho, na escola e no lazer (idem, p. 14). Naturalmente atraentes para os alunos - as plataformas de programação (a exemplo do Flash, voltadas especialmente para a criação de animações), as simulações virtuais (como o software Stellarium, um observatório virtual capaz de simular com precisão o céu em qualquer localidade, data e horário) e também tutoriais inteligentes (sistema que fornece instruções diretas ou feedback aos alunos sem a intervenção de seres humanos), ambientes virtuais de aprendizagem e ambientes virtuais colaborativos (como o Moodle, a Wikipédia e blogs de conteúdos didáticos), dentre outros recursos disponíveis na internet, apresentam possibilidades de inovação no trabalho educacional (SCHIVANI, LUCIANO \& ROMERO, 2012; LONGHINI \& MENEZES, 2011; ARANTES, MIRANDA \& STUDART, 2010).

As tecnologias digitais podem, portanto, estar associadas a materiais diferenciados, de modo a favorecer o desenvolvimento de atividades investigativas envolvendo uma vasta gama de práticas sociais de referência, especialmente para o ensino de física. Conforme discutido a seguir, essa associação pode ser encontrada na Robótica Educacional (RE) (ODORICO, 2004; SILVA, 2008; MORELATO et al, 2010; ZANETTI et al, 2012).

\section{2 - A Robótica Educacional no ensino de física}

O termo "robot" (derivado de "robota", que significa trabalho subordinado ou trabalho exercido de maneira compulsória em línguas eslavas) foi introduzido pela primeira vez em 1920 pelo dramaturgo checo Karel Capek (1890 - 1938) em sua peça "Rossum's Universal Robots (R.U.R.)". Em meados do século XX, marcado com o início de uma era de investigação fértil no campo da inteligência artificial (IA), houve a primeira exploração da ligação entre inteligência humana e máquinas, na qual surgiram os primeiros robôs. Com o passar dos anos e através de diversas inovações tecnológicas, o conhecimento produzido deu origem ao campo da robótica, referido como a ciência e a tecnologia de robôs. Esses robôs, na década de 1960, resultaram da confluência de duas tecnologias: máquinas de controle numérico para fabricação precisa e teleoperadores para manuseio remoto de material radioativo. Em seguida, já na segunda metade do século XX, o desenvolvimento de circuitos integrados, de computadores digitais e a fabricação de componentes cada vez mais eficientes, 
“confiáveis" e em tamanho reduzido, permitiram a programação e desenvolvimento de robôs controlados por computador, denominados de "robôs industriais", com forte aplicação no setor automobilístico. Mais recentemente, os robôs também podem ser encontrados em áreas como limpeza, busca e salvamento, exploração subaquática e espacial e aplicações médicas (SICILIANO \& KHATID, 2008). De acordo com Siciliano \& Khatid (2008, p. 1), na década de 1980, a robótica passou a ser definida como a ciência que estuda a conexão inteligente entre percepção e ação. Desse modo, um sistema robótico seria composto de múltiplas “partes”, cada uma responsável por determinada função, a saber:

Com referência a esta definição, a ação de um sistema robótico é confiado a um aparelho de locomoção para se mover no ambiente (rodas, esteiras rolantes, pernas, propulsores) e / ou um aparelho de manipulação para operar os objetos presentes no ambiente (braços, manipuladores terminais, mãos artificiais), onde atuadores adequados animam os componentes mecânicos do robô. A percepção é extraída dos sensores que fornecem informações sobre o estado do robô (posição e velocidade) e do ambiente que o circundante (força e tátil, alcance e visão). A conexão inteligente é confiada a uma arquitetura de programação, planejamento e controle que se baseia na percepção e modelos disponíveis do robô e do ambiente e explora a aprendizagem e aquisição de habilidades. (SICILIANO \& KHATID, 2008, pp 1-2, grifo do autor. Tradução nossa).

Conforme aponta D’Abreu (1999), o termo "robótica" remete a concepção e construção de robôs, que por sua vez, se utilizam de aparelhos formados por um ou mais dispositivos eletromecânicos (aparelho de locomoção, aparelho de manipulação, atuadores e sensores) capazes de cumprir determinada tarefa, seja de maneira autônoma, previamente programada, ou por meio do controle de um agente externo (uma pessoa, por exemplo).

Nas últimas décadas, com o desenvolvimento da tecnologia aliado à redução dos custos de produção e a percepção de empresas do grande potencial de mercado, robôs "saíram" dos livros de ficção, dos laboratórios de pesquisa e das automações das fábricas e ganharam novos espaços e finalidades. Constata-se que muitos adolescentes de todo o mundo tem acesso a diversos dispositivos eletroeletrônicos e tijolos programáveis, criando mecanismos robóticos com as mais variadas finalidades, desde participar de campeonatos de futebol até a condução de experimentos didáticos em engenharia (FLL, 2014; LUND \& PAGLIARINI, 1999; WANG et al., 2004).

A utilização de tecnologias digitais (como o computador, por exemplo) para fins educacionais tem como precursor o matemático estadunidense Seymour Papert, colaborador 
na criação da linguagem de programação $\operatorname{LOGO}^{10}$ (em 1967) e propositor da teoria construcionista, a qual defende a construção do conhecimento baseada na realização de uma ação concreta que resulta em um produto palpável desenvolvido com o concurso do computador (PAPERT, 1980, 2008). Em meados da década de 1980, Seymour Papert, em parceria com a empresa dinamarquesa Lego, desenvolveu o Lego-Logo, que introduzia motores, sensores e engrenagens nos tradicionais blocos de construção da Lego, possibilitando, assim, controle de diferentes dispositivos e montagens através de programas escritos em linguagem Logo. Esse sistema é a semente dos kits de robótica que seriam comercializados anos mais tarde para fins educacionais, conhecidos como Lego Mindstorms ${ }^{11}$.

Por ser intrinsecamente lúdica e envolver direta ou indiretamente habilidades ligadas ao fazer científico, a robótica passou a ser fortemente considerada nos últimos anos como instrumento educacional (PAPERT, 2008; CÉSAR, 2013, 2009; CABRAL, 2011; MORELATO et al, 2010; LIANG-YI et al, 2009; VALENTE, MAZZONE \& BARANAUSKAS, 2007; ZANETTI et al, 2012; ODORICO, 2004; RUIZ-DEL-SOLAR \& AVILÉS, 2004). Conforme destaca Odorico (2004), a presença das tecnologias digitais em sala de aula, em especial a robótica, busca promover ambientes de aprendizagem interdisciplinares, nos quais os estudantes possam adquirir habilidades para estruturar investigações e resolver problemas concretos, além de estimular o desenvolvimento da criatividade.

Diferente da robótica empregada no setor industrial e na medicina, por exemplo, a Robótica Educacional (RE), também denominada por alguns autores como Robótica Pedagógica (RP) (CÉSAR, 2013, 2009; LIMA, PIRES \& ARAUJO, 2011; ODORICO, 2004; D'ABREU, 1999), tem por principal objetivo práticas educativas que permitam investigar e resolver problemas derivados de distintas áreas do conhecimento humano e práticas sociais. Nesse aspecto, Zanetti et al (2012) destacam que:

Alunos passam a maior parte de seu tempo na escola estudando conteúdos de
matemática e física, sem que possam aplicar tais conceitos no mundo real
em experimentações. Essas experimentações poderiam ser facilmente
amparadas por tecnologias, como softwares de simulação ou a prática de
robótica. [...] A Robótica proporciona, além das questões de motivação e
compreensão de conhecimento, um ambiente de trabalho colaborativo e
atividades interpessoais que muitas vezes não é possível com instrumentos
educacionais convencionais. A prática pode explorar trabalho em equipe,

${ }^{10}$ Projeto LOGO: http://el.media.mit.edu/logo-foundation/index.html Acesso em 4 de maio de 2014.

${ }^{11}$ Lego Mindstorms: http://media.mit.edu/sponsorship/getting-value/collaborations/mindstorms Acesso em 4 de maio de 2014. 
cooperação, criatividade, expressão escrita e oral, organização e habilidades relacionadas à execução de projetos. A RP trabalha competências além daquelas que os currículos escolares trabalham, oferecendo aos alunos experiências reais de áreas da informática, eletrônica, mecânica e design. (ZANETTI et al, 2012, pp. 144-145, grifo nosso).

De maneira geral, a robótica educacional busca promover a aprendizagem dos diferentes saberes disciplinares e o desenvolvimento de determinadas competências como, por exemplo, ler, articular e interpretar símbolos e códigos em diferentes linguagens e representações (sentenças, equações, esquemas, diagramas, tabelas, gráficos e representações geométricas) para resolução de problemas, ou ainda reconhecer a relação entre diferentes grandezas, ou relações de causa-efeito, para ser capaz de estabelecer previsões e tomar decisões de maneira colaborativa ou individual.

Diferentes pesquisas apontam que através de recursos como sensores, acionadores, tijolos programáveis e interfaces gráficas, contidos na robótica educacional, é possível desenvolver habilidades como resolução de problemas lógicos e matemáticos, trabalhar processos criativos, enriquecer o raciocínio crítico e promover a alfabetização científica. Dessa forma, a robótica no cenário educacional em geral, e no ensino de física em particular, pode ser pensada como um conjunto de ferramentas dinâmicas, capazes de influenciar positivamente o processo de aprendizagem em diferentes situações e níveis de escolaridade, promover e valorizar a cooperação, o diálogo e a interação, bem como a capacidade de identificar os fenômenos específicos em um sistema e os fatores que o afeta (CÉSAR, 2013, 2009; CRUZ-MARTÍN et al, 2012; CHALMERS et al., 2012; CHURCH et al, 2010; JÚNIOR et al, 2010; LIMA, PIRES \& ARAUJO, 2011; MITNIK et al., 2009; BARAK \& ZADOK, 2009; LOWE et al., 2008; FRANGOU et al, 2008; ODORICO, 2004).

Porém, é preciso avaliar quais recursos digitais e materiais utilizar para construção dos "robôs", questionar seus custos, benefícios e disponibilidade, bem como sua pertinência para atingir os objetivos de ensino. É possível se valer tanto de tecnologias comercializáveis voltadas especificamente para o setor educacional, quanto da "robótica livre", que se utiliza de materiais de relativo baixo custo ou retirados de sucata.

\subsection{1 - Materiais disponíveis}

Com o custo reduzido de algumas tecnologias digitais, como o próprio computador pessoal, por exemplo, aliado ao desenvolvimento de novas plataformas de prototipagem 
voltadas para o público não especializado, surgem constantemente no mercado vários tipos de dispositivos com rico potencial para o setor educacional, especialmente para o ensino de ciências.

Os sensores disponibilizados nos atuais kits de robótica ou isoladamente são dos mais variados tipos. É possível encontrar sensores de luz, som, velocidade, aceleração, posição, temperatura, pressão, dentre outros (Figura 2). Alguns são componentes empregados para manutenção de diversos aparelhos eletroeletrônicos, porém, podem ser utilizados também para fins didático-pedagógicos (CAVALCANTE, TAVOLARO \& MOLISANI, 2011; SOUZA et al, 2011; COLUCI et al, 2013).

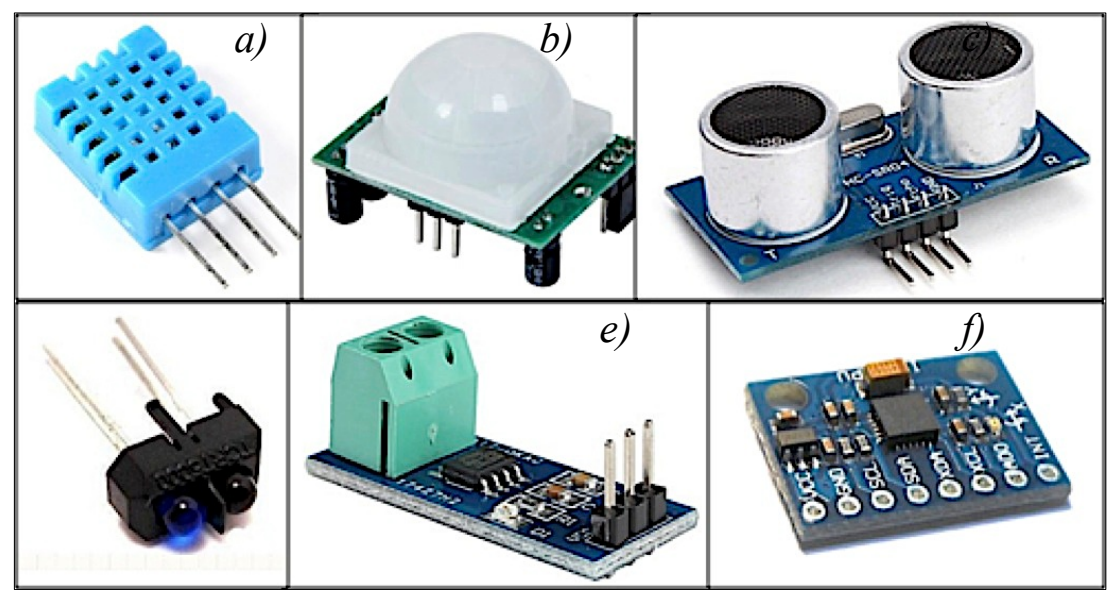

Figura 2 - Sensores: $a$ ) Temperatura e Umidade. b) Movimento. c) Distância. d) Corrente elétrica. e) Reflexão óptica.f) Acelerômetro e Giroscópio. Fonte: http://eletronicos.mercadolivre.com.br/pecascomponentes-eletricos/ Acesso em 11 de maio de 2014.

Para o ensino de física, esses sensores são particularmente interessantes, uma vez que podem ser empregados com eficiência na coleta de dados de uma vasta gama de grandezas físicas, os quais podem ser processados em tempo real ou armazenados para posterior análise via gráficos e planilhas. Assim, é possível a geração de gráficos e o estabelecimento de relações entre grandezas, permitindo um estudo profundo de leis físicas que regem os mais diferentes fenômenos cotidianos. Desse modo, a robótica torna-se um forte aliado no desenvolvimento de atividades experimentais investigativas e de caráter exploratório (SOUZA et al., 2011; MITNIK et al., 2009; BARAK \& ZADOK, 2009; FRANGOU et al, 2008). Vale destacar que tudo isto pode ser realizado fazendo uso de um mesmo conjunto de peças ou kit, reduzindo o custo de novas montagens. Lima et al (2011) aponta que:

A robótica pedagógica utilizando os kits da Lego tem se apresentado como um valioso instrumento de construção e aplicação de conceitos físicos, além de motivador para o processo de ensino-aprendizagem. Diante das 
experiências observadas conseguimos concretizar a expectativa da teoria dos constructos pessoais de que o aprendiz participa do processo de manipulação e planejamento como um aluno inventor, criando hipóteses e as verificando em constante ressignificação de seus constructos. Uma das grandes evidências que as ações dos alunos demonstraram na fase de montagem, planejamento e teste de funcionamento foi a necessidade de conhecer conceitos físicos, ainda não disponíveis em seus currículos escolares, a fim de possibilitar uma maior diversidade de hipóteses para a solução dos desafios. (ibidem, p. 8, grifo nosso).

Os kits da Lego, como o Lego Mindstorms NXT (Figura 3a), são kits comerciais de robótica voltados especialmente para a educação tecnológica (CABRAL, 2011). Mas há também uma vasta gama de outros materiais que podem ser adotados para fins didáticopedagógicos, alguns de relativo baixo custo, a exemplo do Arduino $^{12}$ (Figura 3b), uma plataforma de prototipagem eletrônica de hardware livre que tem por base um circuito com entradas e saídas de sinal digital e/ou analógico (CÉSAR, 2013, 2009; SOUZA et al., 2011). Ambos (Lego e Arduino) possuem suas próprias vantagens e desvantagens, assim como todos os outros materiais desse setor.
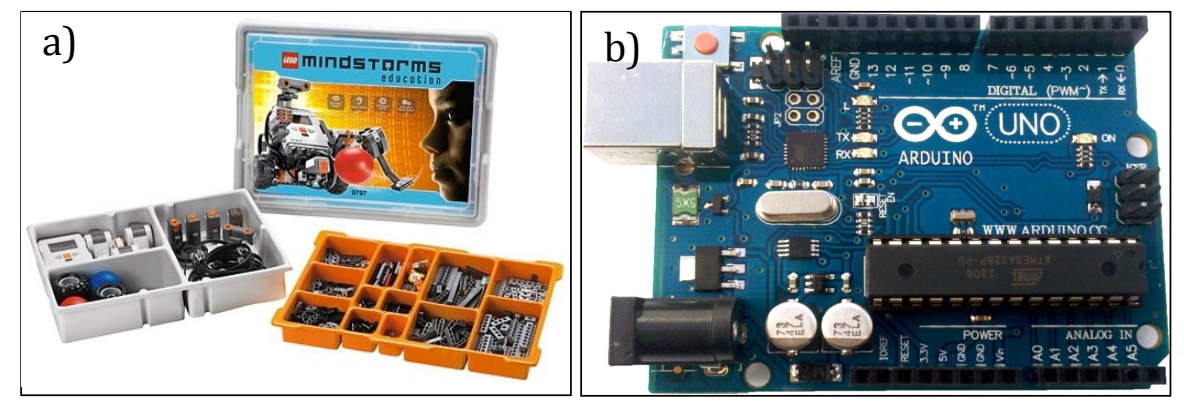

Figura 3 - a) Lego Mindstorms NXT, Kit 9797. b) Arduino, plataforma de prototipagem eletrônica.

Popularmente, os kits da Lego são os mais conhecidos no âmbito da robótica educacional, os quais acompanham motores, peças de plástico rígido em formato de vigas, tijolos cheios, placas, eixos, polias e engrenagens com diferentes dimensões e passivos de conexões entre eles, além de softwares, tijolos programáveis e sensores (p. ex.: campo magnético, acelerômetro, ultrassom e rotação). Entretanto, apesar de se destacar em versatilidade, o preço elevado para aquisição desses materiais e sua pouca oferta no mercado nacional podem constituir um obstáculo a sua utilização em sala de aula.

O Arduino, por sua vez, também possui ampla versatilidade, fazendo uso de uma vasta gama de sensores e componentes. Todavia, ao contrário dos componentes da Lego, os do

\footnotetext{
${ }^{12}$ Apesar do Arduino em si não tratar de um kit de robótica, ele é comumente vendido comercialmente em conjunto com outros mecanismos, como sensores, display, protoboards, acionadores e cabos de conexão, vide: http://www.amazon.com/SunFounder-Project-Starter-Arduino-Mega2560/dp/B00D9NMP6M/ref=pd sxp grid i 10 Acesso em 18 de outubro de 2014. 
Arduino são em sua maioria facilmente encontrados em lojas de eletrônica e a custo reduzido, além de contar com um software e hardware livres, o que amplia o número de aplicações. Entretanto, por estar em um nível mais fundamental em termos de eletroeletrônica, não há um padrão de fabricação/ aplicação dos componentes com os quais o Arduino se comunique (pode-se usar desde componentes extraídos de sucatas até sensores empregados na indústria e aeromodelismo), com isso a comunicação entre o hardware-hardware e hardware-software pode gerar obstáculos para o desenvolvimento das montagens. Com isso, o Arduino demanda uma prática contínua e estudo prévio de conceitos de eletrônica e de programação de computadores (ZANETTI et al, 2012).

Podemos citar ainda o Modelix ${ }^{13}$, Knex $^{14}$ e o FischerTechnik ${ }^{15}$ (Figura 4). Esses kits seguem relativamente uma mesma linha de versatilidade e criatividade em suas montagens e atividades quando comparado aos kits da Lego, por exemplo. Contudo, fazem uso de outros tipos de materiais, com dimensões e encaixes próprios, além de custos variados e disponibilidade diversa no mercado nacional..

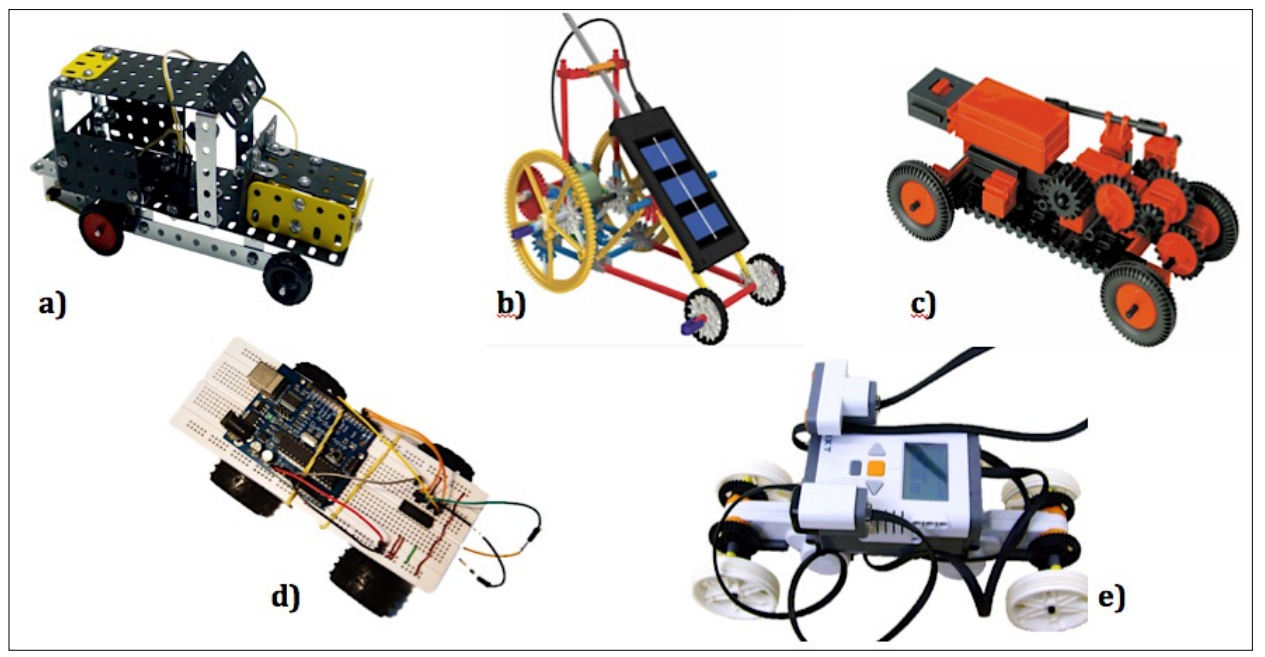

Figura 4 - Montagens de veículos usando diferentes materiais/ kits.

a) Modelix. b) Knex. c) FischerTechnik. d) Arduino. e) Lego Mindstorms.

Em contrapartida, o acesso e aquisição de alguns desses recursos tecnológicos para fins didáticos, seja pela população em geral ou através das instituições, como as escolas e centros educacionais, pode constituir-se em grande desafio, apresentando custos elevados para a realidade brasileira em particular (FERNANDES, SÁ \& GONÇALVES, 2012; SANTOS, NASCIMENTO \& MARTINS, 2010). Por esse motivo, vários pesquisadores buscam

\footnotetext{
${ }^{13} \mathrm{http} / / / \mathrm{www}$. leomar.com.br/modelix/ Acesso em 19 de março de 2013.

14 http://www.knex.com.br/ Acesso em 19 de março de 2013.

15 http://www.fischertechnik.de/en/home.aspx Acesso em 19 de março de 2013.
} 
alternativas para o desenvolvimento de outros recursos e utilização de materiais diferenciados que permitam explorar a robótica para fins educacionais, porém, com custos reduzidos e oferta de plataformas livres (AROCA, 2012; MIRANDA, SAMPAIO \& BORGES, 2010; MORELATO et al, 2010; CÉSAR, 2009; GONÇALVES, 2007). Nesse aspecto, Aroca (2012) apresenta uma revisão bibliográfica listando projetos de robôs (publicados em revistas especializadas e congressos da área) construídos com materiais "alternativos", considerados de baixo custo pelos autores. Nessa lista estão incluídas informações resumidas sobre o custo (em dólares) e as principais características desses robôs (Tabela 2).

Tabela 2 - Robôs considerados de "baixo custo". Tabela adaptada de Aroca (2012, p. 33).

\begin{tabular}{|c|c|c|}
\hline Robô & $\begin{array}{c}\text { Custo (US\$) } \\
\text { (ano de referência: } \\
2011 / 2012 \text { ) } \\
\end{array}$ & Principais características e/ou componentes \\
\hline Suckerbot & 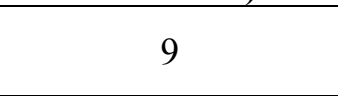 & $\begin{array}{l}\text { Motores, seguidor de linha, sensor de toque unidirecional, } \\
\text { alimentação e controle via USB }\end{array}$ \\
\hline Baobot & 31 & $\begin{array}{l}\text { Motores, seguidor de linha, compatível com Arduino, } \\
\text { alimentação e controle via USB ou operação autônoma }\end{array}$ \\
\hline Afrobot & 10 & $\begin{array}{c}\text { Microcontrolador MSP430, motores, seguidor de luz, } \\
\text { detector de obstáculos }\end{array}$ \\
\hline RoboArm & 50 & $\begin{array}{l}\text { Braço robótico, interface com computador via sensores de } \\
\text { luz na tela }\end{array}$ \\
\hline Kilobot & 43 & $\begin{array}{c}\text { Locomoção por vibração, comunicação em grupo e com PC, } \\
\text { microcontrolador }\end{array}$ \\
\hline SwarmRobot & 10 & $\begin{array}{c}\text { Compatível com Arduino, motores, sensor de objetos e de } \\
\text { obstáculos }\end{array}$ \\
\hline SEG & 14 & $\begin{array}{c}\text { Estilo Segway, microcontrolador, motores, rodas montadas } \\
\text { como Origami }\end{array}$ \\
\hline DiscBot & 47 & $\begin{array}{c}\text { Motores de passo, compatível com Arduino, sonar, estrutura } \\
\text { de madeira cortada à laser }\end{array}$ \\
\hline MITBOTS & 33 & $\begin{array}{l}\text { Processador ARM, tela de LCD, blocos de montagem, } \\
\text { motores }\end{array}$ \\
\hline N-Bot & 14 & $\begin{array}{c}\text { Motores, controlado por canal de áudio, compatível com } \\
\text { celulares ou computadores }\end{array}$ \\
\hline SH-EDUC & 84 & $\begin{array}{l}\text { Uso de sucata em conjunto com Microcontrolador PIC, tela } \\
\text { de LCD, sonar, sensores de luz, toque e temperatura }\end{array}$ \\
\hline R-One & 200 & MSP430, motores, giroscópio, acelerômetro \\
\hline Finhch & 99 & $\begin{array}{l}\text { Motores, acelerômetro, sensores de luminosidade e toque, } \\
\text { LEDs, câmera, microfone e alto falantes }\end{array}$ \\
\hline LUDEBot & 250 & Servos, compatível com Arduino, sonar, PC opcional \\
\hline
\end{tabular}

Em suma, é patente a gama de materiais disponibilizados no âmbito da robótica educacional e sua versatilidade, com vasta opção de sensores, acionadores e peças com encaixes próprios que permitem o desenvolvimento de múltiplas estruturas físicas, além de softwares com interface gráfica intuitiva e de fácil utilização. Contudo, a mera presença em 
sala de aula dos recursos digitais associados a materiais diferenciados não significa que o processo de ensino e aprendizagem será automaticamente favorecido, é preciso uma avaliação e adequação didático-pedagógica desses materiais, especialmente quando se objetiva ensinar conceitos científicos. Reconhecemos que contar com novos e emergentes recursos oferecidos pelas novas tecnologias não necessariamente implica no enriquecimento da aula.

\subsection{2 - Desafios.}

Ainda que possua um enorme potencial para o ensino e aprendizagem de Física, conforme destaca Mitnik et al (2009), grande parte das atividades elaboradas estão direcionadas ao tratamento de conteúdos intimamente relacionados à própria robótica, tais como programação, construção de robôs, inteligência artificial ou a elaboração e desenvolvimento de algoritmos. Para nós, tal fato é bastante compreensível visto que qualquer processo com esse grau de inovação no ambiente escolar constitui-se em um grande desafio (ALIMISIS, 2013; BENITTI, 2012). Somado a isso, como bem aponta Benitti (2012),

\footnotetext{
Vários projetos de robôs de menor custo são encontrados na literatura (como mencionado anteriormente), mas há falta de projetos numa perspectiva mais ampla, contemplando avaliações sistemáticas e delineamento experimental de confiança, com proximidade à realidade das escolas e uma orientação clara sobre as "rotas mais seguras" para impulsionar os benefícios de aprender pela robótica. (BENITTI, 2012, p. 987. Tradução nossa).
}

Ao se transpor para as salas de aula uma tecnologia relativamente recente e tão distante do presente tradicional sistema de ensino, é esperado o surgimento de dificuldades associadas às suas especificidades. Corre-se o risco, por exemplo, de se enfocar justamente os elementos mais "controláveis" da inovação, ou seja, sua dimensão técnica, restringindo-se o ensino e a aprendizagem dos estudantes aos processos envolvidos na montagem e no funcionamento dos robôs. Entretanto, cabe ressaltar que:

[...] a simples existência dessas novas tecnologias num processo didáticopedagógico, não o torna mais rico, estimulante, desafiador e significativo para o aprendiz. Não saber adequar o uso pedagógico das novas tecnologias, significa permanecer tradicional usando novos e emergentes recursos. (SENA DOS ANJOS, 2008, p.573, grifo nosso).

Uma das maiores dificuldades didáticas na implementação de propostas inovadoras com uso de robótica encontra-se na necessidade de integrar os diversos conhecimentos necessários para sua realização. Podem-se vislumbrar aplicações da robótica no cenário educacional apenas no domínio de um determinado conjunto de regras ou métodos. Em outras 
palavras, o aluno pode apreender de modo mecânico os algoritmos envolvidos na construção de uma determinada montagem, receber toda a programação pronta e realizar uma atividade inteira sem considerar os aspectos físicos (conceituais e teóricos) envolvidos na sua condução. Por outro lado, o uso da robótica pode servir para reforçar o uso limitado de técnicas no cumprimento de tarefas determinadas. Nestas duas opções de uso, há uma pequena preocupação com o conhecimento científico conectado ao que ele (discente) está fazendo.

Tanto no processo mecânico de aprendizagem quanto no de reforço e uso limitado de técnicas, podemos afirmar que há uma baixa (ou nenhuma) mobilização dos saberes disciplinares necessários para compreender e/ou solucionar a situação posta na problematização. Isso fica mais evidente quando se observa a resolução de problemas por tentativa e erro, sem, de fato, fazer uso de um raciocínio estruturado e lógico, embasado numa teoria ou conjunto de conceitos. No âmbito da robótica no ensino, problemas e desafios solucionados por tentativas e erros não são incomum. Barak \& Zadok (2009) destacam que:

A primeira questão da pesquisa que levantamos neste estudo foi: como fazer com que os alunos possam avançar com soluções criativas de problemas no contexto das atividades de robótica? As observações feitas no segundo e terceiro ano do presente estudo indicaram que no primeiro projeto, os alunos muitas vezes começavam a construir o sistema em que estavam trabalhando de imediato e prosseguiam por ciclos de tentativas e erros. (BARAK \& ZADOK , 2009, p. 303. Grifo nosso). Tradução nossa.

Em estudos anteriores (ROUXINOL et al., 2011) identificamos essa mesma postura: dependendo do problema a ser solucionado, os estudantes centravam sua atenção majoritariamente na técnica, na parte prática da atividade, sem muito se preocupar com o entendimento conceitual daquilo que estavam tratando, somente depois de algumas tentativas e erros é que "perceberam que a intuição inicial não dava conta de resolver a situação" (ibidem, p.7).

De um modo geral, quando olhamos para as atividades de robótica, especialmente aquelas presentes em campeonatos e torneios, a exemplo do FIRST (do inglês, For Inspiration and Recognition of Science and Technology) ${ }^{16}$, nas quais os estudantes são direcionados para o cumprimento eficaz de determinada tarefa e/ ou desafio, a face emersa do iceberg que se observa remete justamente ao predomínio de técnica (s) ${ }^{17}$. Essa postura pode restringir o ensino e a aprendizagem dos estudantes aos processos envolvidos na montagem e no funcionamento dos robôs, com foco justamente nos elementos mais "controláveis" da

\footnotetext{
16 Para maiores informações vide, p. ex.: http://www.brfirst.org Acesso em 10 de maio de 2012.

17 Vide, p. ex.: http://www.sesisp.org.br/robotica/competicao.asp Acesso em 10 de maio de 2012. 80
} 
inovação, ou seja, na sua dimensão técnica. Ou ainda, apoiar-se em uma dada realidade com pretexto de contextualização mas que, ao final das contas, serve meramente como uma ilustração, sem fins didático-pedagógicos mais profundos.

É claro que, dependendo da intenção didática do educador, pode-se objetivar que o aluno apenas desenvolva a habilidade de programação ou construção de robôs. Entretanto, essa postura não é interessante quando se pensa a robótica dentro de um processo educacional mais amplo, especialmente quando empregada no ensino de Ciências na educação básica, uma vez que aspectos teóricos e conceituais ganham destaque na formação do educando. Assim, para que uma inovação possa figurar, de fato, no contexto educacional, é necessário compreender o papel que cada esfera de conhecimento desempenha no sistema de ensino. Isto é necessário, pois é preciso que sua inserção faça sentido para os alunos, que seja inteligível e criada a partir de claros objetivos formativos.

Por essa razão, ao se explorar o uso efetivo da robótica como instrumento educacional no ensino de Física, é preciso a criação de atividades que possam relacionar os conhecimentos físicos a serem ensinados com os elementos intrínsecos a essa tecnologia. Ou seja, é preciso que haja uma associação entre a teoria e os conceitos físicos tratados (o "porquê") com a prática (o "fazer"). Porém, como analisar se tal conexão está, de fato, sendo feita? Como analisar as relações entre as características intrínsecas da robótica e o conteúdo científico presentes em uma proposta de inovação? Como garantir que existe uma ressonância entre estes dois conjuntos distintos de conhecimentos, a fim de otimizar seu uso no processo de ensino e aprendizagem de Ciências, especialmente no ensino de Física?

Constitui-se um desafio operacionalizar o uso da tecnologia por meio do desenvolvimento de estratégias que a implementem efetivamente em sala de aula. Isso requer mais do que instalar computadores nas escolas, adquirir kits de robótica e desenvolver repositório de recursos instrucionais. É preciso que a aprendizagem ocorra com os computadores e não a partir deles, ou seja, que essas novas tecnologias sejam utilizadas vinculadas às necessidades de formação. "O uso de equipamentos tecnológicos em sala de aula de forma alguma pode ser visto como um novo patamar de educação sem a implementação de mudanças no modo de agir e pensar" (SILVA, 2012, p. 52).

Transpor para a prática o desejo de que os alunos sejam protagonistas no processo de ensino-aprendizagem constitui-se um dos obstáculos enfrentados pelos professores, além daqueles relacionados à própria formação e ao pouco contato do corpo docente com o uso 
desses recursos em sala de aula. Esta árdua tarefa passa pela análise da pertinência e do potencial de utilização de atividades que fazem uso dessas tecnologias no Ensino de Física.

Com isso, pensando no ensino de ciências em geral, e da Física em particular, nos questionamos como melhor explorar o potencial que os instrumentos da robótica educacional apresentam, especialmente no âmbito da contextualização? Como melhor promover a problematização e mobilizar os saberes disciplinares, especialmente os da Física, fazendo uso desses recursos?

\section{3 - Contextualização via instrumentos da Robótica Educacional.}

Conforme apresentado anteriormente, os kits de robótica utilizam uma vasta gama de materiais, desde peças de encaixe de plástico, metal ou madeira, sob diferentes formatos com diferentes dimensões e passivos de conexões entre eles, até softwares, tijolos programáveis e sensores. Isso aponta também para o rico potencial que instrumentos dessa natureza possuem ao se pensar no ensino de Ciências imerso num processo de contextualização, uma vez que permitem explorar e problematizar através de seus mecanismos grandezas físicas (velocidade, aceleração, tempo, força, posição, campo magnético, temperatura, etc.) e fenômenos físicos dos mais diversas (som, ultrassom, intensidade luminosa, transferência de calor, movimento harmônico, capacitância, movimento circular e retilíneo, etc.). Dessa forma, é possível a criação de inúmeras estruturas/sistemas (estufas automatizadas, leitor de código de barras, sistemas de comunicação, veículos, androides, casas "inteligentes", sistemas de frenagem, sismógrafos, maquinários, etc.), potencializando a mimetização de uma vasta gama de situações "reais", presentes no cotidiano do aluno ou na sociedade em geral, configurando-se em "realidades" ou práticas sociais que podem ser tomadas como referência e problematizadas.

A versatilidade da robótica permite ainda a criação de cenários que seriam impraticáveis, ou até mesmo impossíveis de serem criados de outra maneira no contexto escolar. Tal impossibilidade deve-se ou à necessidade de garantir a integridade física dos alunos ou mesmo por restrições estruturais e/ou econômicas em situações como, por exemplo: construção de elevadores de carga, colisão de veículos, construção de pontes levadiças, transporte e seleção automatizada de cargas, dentre outros. Isso tudo pode ser realizado fazendo uso de um mesmo conjunto de peças ou kit, reduzindo o custo de novas montagens (WANG et al, 2004). 
Assim sendo, nossa hipótese é a de que materiais dessa natureza potencializam o desenvolvimento de atividades com problematizações as quais permeiam uma vasta gama de práticas sociais, práticas essas que podem servir de base na composição da realidade (pontos de partida e chegada da contextualização), e em diferentes níveis do processo educacional formal, do Ensino Fundamental ao Ensino Técnico e Superior. Assim, a adoção de uma perspectiva contextualizadora, conforme apresentado no capítulo anterior e adotado nesse estudo, poderia contribuir positivamente para esse processo de inserção da RE no ensino de Física, em atividades ou sequências didáticas que mobilizem os saberes disciplinares em sala de aula de tal modo que a realidade seja percebida e que se transforme em objeto de reflexão, alterando, na medida do possível, a relação entre os educandos e os objetos contidos em tal realidade. Por essa razão, dado o panorama geral traçado até aqui, os kits e/ou componentes da robótica educacional (comercializáveis ou livres) constituem o principal recurso didáticopedagógico que iremos adotar para investigar a contextualização no ensino de Física dentro dos moldes teóricos-metodológicos aqui adotados.

\subsection{1 - Questões centrais e objetivos da pesquisa}

De um modo geral, dependendo da intenção didática do educador, pode-se até esperar que o aluno apenas desenvolva habilidades técnicas como construção de gráficos ou montagem de sistemas e estruturas físicas. Entretanto, ao se pensar a robótica dentro de um processo educacional mais amplo, especialmente no âmbito da contextualização no ensino de Ciências, o componente conceitual/teórico se torna naturalmente importante e pertinente. É preciso buscar uma cuidadosa negociação entre esses fatores (habilidades técnicas e o componente conceitual/teórico) para que sejam diminuídos os riscos de desperdiçar o potencial da RE como instrumento de ensino.

Conforme destacam alguns autores, a robótica no ambiente escolar cria um rico campo de pesquisas em inovação, com aplicações ainda a serem exploradas no Ensino de Ciências, seja no cenário nacional, seja no internacional (ALIMISIS, 2013; BENITTI, 2012; CRUZMARTÍN et al., 2012; JÚNIOR, VASQUES \& FRANCISCO, 2010; BARAK \& ZADOK, 2009). Nesse aspecto, Benitti (2012), por exemplo, destaca que:

Investimentos em formação de professores, além do custo de aquisição de equipamentos (robôs), reforçam a necessidade de estudos de investigação / pesquisa que demonstrem claramente os benefícios de cada abordagem para o uso da robótica na educação, visando orientar as escolas para o uso eficaz desta tecnologia. (idem, p. 987.) Tradução nossa. 
Já no cenário nacional, Júnior, Vasques \& Francisco (2010) ressaltam também os desafios para implementação da robótica educacional nas escolas brasileiras, destacando que:

O tema escolhido - Robótica Educacional - não é ainda muito discutido no cenário acadêmico brasileiro. A partir do levantamento, da compilação e da análise das pesquisas pode-se perceber que este campo de investigação é interdisciplinar, complexo e potente, considerando as demandas educacionais contemporâneas. [...] Implantar a tecnologia nas escolas é um desafio a ser vencido. Mas isso só acontecerá quando a potencialidade deste recurso for compreendida e incorporada crítica e reflexivamente pelos professores, alunos e demais membros da comunidade escolar, como dirigentes, funcionários administrativos e pais. Um processo que se encontra por fazer. (idem, p. 50).

Podemos indagar ainda em que medida a robótica pode gerar situações de ensino que favoreçam a aprendizagem de conteúdos científicos, de modo a estimular o aluno a refletir e interligar teoria e prática ao longo da resolução e investigação dos problemas propostos, especialmente de Física? Como analisar atividades ou sequências didáticas que façam uso desses instrumentos (RE), de modo que se perceba claramente o quanto "dialogam" (ou não) com a situação que se deseja contextualizar? Nesse caso, haveria "elementos" ou "norteadores" que possam servir de base para fomentar a problematização e interligar os pontos de partida e chegada, independente da prática social de referência (tanto uma atividade de pesquisa quanto doméstica e cultural), de modo a melhor evidenciar o processo de contextualização almejado na atividade ou sequência didática? Tais questões permeiam o problema central desta tese.

Com base no cenário geral apresentado até aqui, além das questões expostas, é possível sintetizar a hipótese central dessa pesquisa da seguinte maneira:

O planejamento e análise de atividades ou sequências didáticas inovadoras que fazem uso de instrumentos da robótica educacional podem promover a contextualização no ensino de Física de tal modo que os saberes disciplinares sejam mobilizados e que a realidade seja percebida e transformada em objeto de reflexão.

Temos ciência de que não encontraremos uma fórmula única para sanar todos os problemas educacionais, não existe um elixir didático-pedagógico, pois "não há soluções que sejam panacéias para o Ensino de Física e isso vale para quaisquer outros campos cognitivos" (BASTOS FILHO, 2006, p.98). Entretanto, nos propomos a investigar de que forma as novas tecnologias presentes no cenário educacional, nesse caso, a robótica, podem ser melhor exploradas no processo de ensino e aprendizagem da Física, levando-se em consideração uma abordagem contextualizadora. Com isso, o objetivo geral dessa tese é, essencialmente: 84 
contribuir para que sejam identificados "elementos" ou "norteadores" importantes a serem considerados durante o desenvolvimento e análise de sequências didáticas, de tal forma que as situações tiradas de uma dada "realidade", de uma prática social, sirvam, de fato, como referência, e sejam transformadas em objetos de reflexão ao longo do processo de ensino e aprendizagem.

Esperamos, assim, que esse trabalho possa auxiliar pesquisadores, educadores e professores em geral, a melhor compreender os limites e possibilidades da robótica nesse cenário, norteando passos que visem a contribuir com alternativas para o melhor desenvolvimento de práticas inovadoras.

Para alcançar esses objetivos e responder, ao menos em parte, as questões levantadas, é preciso a adoção de um referencial teórico adequado, que permita analisar esse cenário tanto na perspectiva educacional quanto do ponto de vista das organizações sociais e suas ações que permeiam as possíveis "realidades" ou situações exploradas na contextualização. Por essa razão, fundamentamos nossa investigação com base na Teoria Antropológica do Didático (TAD), desenvolvida pelo matemático francês Yves Chevallard (CHEVALLARD, 1999). De modo geral, podemos encontrar em Bosch et al (2011) um espectro dos tipos de uso e aplicação desta teoria fora do domínio específico da Matemática. No caso da Física, há de se considerar sua especificidade epistemológica de ser uma disciplina com conteúdo empírico. No entanto, por se propor a tratar de todo e qualquer campo da atividade humana, a TAD encontra na Física, enquanto área de conhecimento, campo fértil para prospecção de tarefas e corpos teóricos de conhecimento que lhe sustentam a execução. Assim, como mostraremos a seguir, a TAD pode ser aplicada a atividades de ensino de Física, embora ainda seja restrito o número de trabalhos que se proponham a isto (BOSCH et al, 2011). Esse referencial é, então, apresentado e discutido em detalhes no capítulo seguinte, capítulo 3. 


\section{Capítulo 3 - A TEORIA ANTROPOLÓGICA DO DidÁtico E A NOÇÃo DE VEROSSIMILHANÇA PRAXEOLÓGICA.}

[...] não me parece possível nem aceitável a posição ingênua ou, pior, astutamente neutra de quem estuda, seja o físico, o biólogo, o sociólogo, o matemático, ou o pensador da educação. Ninguém pode estar no mundo, com o mundo e com os outros de forma neutra. Não posso estar no mundo de luvas nas mãos constatando apenas. A acomodação em mim é apenas caminho para a inserção, que implica decisão, escolha, intervenção na realidade. Há perguntas a serem feitas insistentemente por todos nós e que nos fazem ver a impossibilidade de estudar por estudar. De estudar descomprometidamente como se misteriosamente de repente nada tivéssemos que ver com o mundo, um lá fora e distante mundo, alheado de nós e nós dele.

Paulo Freire ${ }^{18}$

\section{1 - A Teoria Antropológica do Didático (TAD).}

A Teoria Antropológica do Didático (TAD) constitui-se em uma abordagem teórica dentro da tradição francesa de considerar didáticas específicas (ASTOLFI, 2001). A TAD se insere dentro do projeto de criação da disciplina "Educação Matemática", com estruturas conceituais e metodológicas próprias. Segundo Bosch, Chevallard \& Gascón (2006, p. 2):

Em seu início, durante os anos 70, a Teoria das Situações Didáticas (Brousseau, 1997) foi uma das primeiras a declarar a necessidade de uma abordagem científica específica para os problemas de ensino e aprendizagem de Matemática. (ibidem. Tradução nossa).

${ }^{18}$ In. Pedagogia da Autonomia. 36a edição, São Paulo: Editora Paz e Terra, 2007, p. 77. 
Proposta pelo matemático francês Yves Chevallard (CHEVALLARD, 1999b; CHEVALLARD, BOSCH \& GASCÓN, 1997), a TAD emergiu como uma consequência natural da sua Teoria da Transposição Didática (CHEVALARD, 1985, 1992). Nesse aspecto, como bem aponta Zanardi, Pereira \& Kneubil (2012, p. 7),

[...] na Transposição Didática, os objetos principais de Chevallard são o saber, o aluno e o professor, já na Teoria Antropológica da Didática o objeto é a atividade humana regular, como resultado de um saber, que pode ser sábio, a ensinar ou ensinado, aplicado nas diferentes tarefas, técnicas, tecnologias e teorias. (ibidem).

Com isso, segundo a TAD, a Matemática deve ser interpretada como uma atividade humana, assim como diversas outras e não apenas um sistema conceitual, uma linguagem ou forma de pensar (BOSCH, CHEVALLARD \& GASCÓN, 2006). Dessa maneira, pode, em princípio, ser aplicada a qualquer tipo de atividade na qual seja possível definir tarefas a serem executadas e os conhecimentos que estão na base de sua execução. Madsen \& Winslow (2009) aplicam a TAD para estudar a relação pesquisa-ensino entre universitários da Dinamarca em duas áreas distintas: geologia e matemática. Da mesma forma, Marandino e Mortensen (2011) usam a TAD para estudar as formas de transposição didática e proposição de tarefas em museus.

A TAD é composta de dois aspectos complementares, mas independentes: o primeiro refere-se às características estruturais, descritas em termos de praxeologias, e o segundo, remete às características funcionais, centradas na ideia de momentos didáticos (CHEVALLARD, 1999). Vamos discutir inicialmente a noção de praxeologia e suas particularidades para depois entrar no aspecto funcional da TAD..

\section{2 - A noção de praxeologia e as Organizações Praxeológicas (OP).}

De acordo com Kotarbinski (1975, p. 16, apud SWIATKIEWICZ, 1997, p. 638), a noção de "praxeologia, num determinado sentido, é algo muito novo e, noutro sentido, algo muitíssimo velho. É nova, enquanto especialidade científica a nascer e, é velha, enquanto conhecimento pré-científico, conhecimento geral". O termo Praxeologia tem sua origem na junção de duas palavras de origem grega, práxis, que remete à prática de determinada tarefa, e logos, indicando estudo de algo.

No contexto da TAD, uma Praxeologia é expressa pelo conjunto $[\mathbf{T}, \boldsymbol{\tau}, \boldsymbol{\theta}, \boldsymbol{\Theta}]$, onde T representa tipo de tarefa, a qual pode se ramificar em inúmeras tarefas $[\mathrm{t}], \tau$ representa a 
técnica, $\theta$ a tecnologia e $\Theta$ remete a teoria (CHEVALLARD, 1999). Ela pode ser empregada para entender as ações e atividades humanas as quais são representadas. Essa estrutura permite investigar a prática de determinada tarefa correlacionando-a com um logos, ou seja, com uma componente teórico conceitual. Mortensen (2010), por exemplo, utiliza esse aspecto estrutural da TAD para investigar a experiência e compreensão dos visitantes em uma exposição de imersão de um museu de ciências, busca verificar divergências e convergências entre a praxeologia pretendida com a exibição com a praxeologia observada dos visitantes naquela exposição. Já Nogueira (2008), analisa a introdução da álgebra presente em livros didáticos do ensino fundamental, para isso, faz uso de organizações praxeológicas enquanto referencial teórico e metodológico. Na mesma linha de investigação de livros didáticos, Zanardi (2013), analisa em termos de tarefas, técnicas, tecnologias e teorias, como se apresentam conteúdos relativos à equação de Clapeyron em livros de Física e Química do ensino médio. Também publicamos algumas pesquisas adotando a TAD em geral e a Praxeologia em particular para analisar e desenvolver atividades didáticas que se utilizam de instrumentos da robótica educacional no ensino de Física. Notou-se, dentre outras coisas, que a TAD, especialmente sua componente estrutural, mostra-se como uma ferramenta teórica potencialmente adequada para entender os limites e possibilidades da robótica em situações que envolvam tarefas que demandem conhecimento específico de Física (SCHIVANI \& PIETROCOLA, 2013, 2012; SCHIVANI, BROCKINGTON \& PIETROCOLA, 2013).

A noção de praxeologia permite ainda modelar e organizar o conhecimento por meio daquilo que Chevallard denomina de Organização Praxeológica (OP), a saber:

Uma tal praxeologia - ou organização praxeológica - está, pois, constituída por um bloco prático-técnico, $[\mathrm{T}, \tau]$, e por um bloco tecnológico-teórico, $[\theta$, $\Theta]$. O bloco $[\theta, \Theta]$ é frequentemente identificado como um saber, enquanto o bloco $[\mathrm{T}, \tau]$ é o saber-fazer. Por metonímia se designa comumente como "saber" a praxeologia $[\mathrm{T}, \tau, \theta, \Theta]$ completa, ou mesmo qualquer parte dela. (CHEVALLARD, 1999, p. 6. Grifo do autor). Tradução nossa.

Por envolver qualquer tipo de atividade na qual seja possível definir tarefas a serem executadas e os conhecimentos que estão na base de sua execução, uma organização praxeológica pode ser de diferentes tipos: didática, física, matemática, química, artesã, industrial, rural, doméstica, etc. Assim, conforme ressaltam Barbé et al (2005),

A Teoria Antropológica do Didático considera que a noção de organização praxeológica pode ser aplicada a qualquer forma de atividade humana, e não apenas para a matemática. Em particular, ela pode ser usada para descrever a prática do professor e do aluno em termos de praxeologias didáticas ou organizações didáticas. (idem, p. 239, grifo nosso). Tradução nossa. 
Esse tipo particular de organização (didática) é entendido, a priori, como o conjunto dos tipos de tarefas, de técnicas, de tecnologias, etc., mobilizados para o estudo específico de determinada "obra", em uma instituição própria (CHEVALLARD, 1999, p. 18). Portanto, podemos chamar essa organização de Organização Praxeológica Didática (OP didática). Independente do tipo, uma organização praxeológica completa possui dois blocos distintos, porém, correlacionados: o bloco prático-técnico [T, $\boldsymbol{\tau}]$, o qual pode ser entendido como o

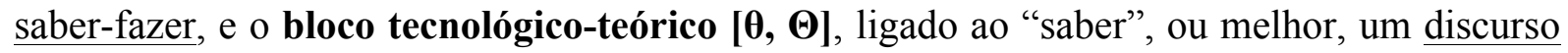
lógico que permite justificar e compreender o bloco prático-técnico.

\subsection{1 - Bloco prático-técnico (práxis)}

\section{Tipo de tarefa [T] e Tarefa [t]}

Segundo Chevallard tudo aquilo que é solicitado para uma pessoa fazer, mediado por verbos, pode ser designado como tarefa. Nesse sentido, tarefa evoca uma ação, um modo de realizar algo. É uma ramificação de uma rede mais ampla chamada pelo autor de tipo de tarefa [T] (CARVALHO, 2007). Quando uma tarefa t está relacionada com um tipo de tarefa $\mathrm{T}$, dizemos que $[\mathrm{t} \in \mathrm{T}]$. Assim, resolver a expressão $2 \boldsymbol{x}=\mathbf{4}^{\mathbf{3}}$ e calcular o limite $\lim _{x \rightarrow \infty}\left(1+\frac{1}{x}\right)^{3}$ são tarefas relativa a T (por exemplo: resolver a expressão tal, ...). O conceito de tarefa supõe um objeto relativamente preciso. Calcular o limite $\lim _{\boldsymbol{x} \rightarrow \mathbf{4}}\left(\boldsymbol{x}^{2}-\right.$ $5 x+3$ ) remete a um tipo de tarefa, porém, calcular apenas, não remete. Nesse caso, calcular (somente!) é o que Chevallard chama de um gênero de tarefas, a qual, por sua vez, demanda uma determinação. Nesse sentido, um gênero de tarefas é apresentado sob a forma de diferentes tipos de tarefas, incluindo o conteúdo intimamente relacionado. Em nosso caso, essa compreensão é de suma importância, uma vez que as atividades presentes na RE, mesmo que estejam tratando de uma única fenômeno ou conceito físico, podem demandar um conjunto amplo de fazeres, desde a montagem dos robôs até a programação e cálculo das grandezas físicas em jogo e uso adequado dos sensores e tijolos programáveis. Portanto, podemos ter um tipo de tarefa T que seja "calcular a velocidade do veículo", a qual engloba uma tarefa " $\mathrm{t}$ ", calcular a velocidade do veículo em MRU usando dados coletados pelo sensor tal..., tudo isso dentro de um gênero "calcular". 


\section{Técnica $[\tau]$}

Uma praxeologia relativa a $T$ requer uma maneira de fazer, resolver $\mathbf{t} \in \mathbf{T}$. A esta maneira Chevallard dá o nome de técnica $[\tau]$. Assim, técnica faz referência direta a maneira de realizar determinada tarefa pertencente à $\mathrm{T}$, nesse sentido, diz-se que a técnica é o 'saberfazer' e só tem sentido quando ligada a uma Tarefa a qual ela é relativa.

No ensino de Física, como bem apontam Diogo, Osório \& Silva (2007), um exemplo comum de técnica é aquela associada à determinação da posição e do tempo de encontro entre dois objetos em movimento retilíneo uniforme, problema recorrente nas aulas e em livros didáticos de mecânica do primeiro ano do ensino médio. Para resolver esse tipo de tarefa $\left[\mathrm{T}_{1}\right]$, uma técnica possível $\left[\tau_{1}\right]$ é escrever as funções horárias da posição em função do tempo dos dois objetos, igualando-as em seguida para calcular a incógnita "tempo". Na sequência, o valor encontrado para o tempo do encontro é usado nas funções horárias de cada móvel para se descobrir a posição em que ocorreu o encontro. Outra técnica viável $\left[\tau_{2}\right]$ para resolver esse mesmo problema consiste na adoção de um sistema cartesiano, com o eixo das abscissas representando o tempo e o das ordenadas, a posição de acordo com a função horária de cada móvel. Uma vez construído o gráfico das duas funções, obtêm-se a posição e o instante do encontro por meio do ponto de interseção das duas retas.

Em uma Instituição [I], em face de determinado Tipo de tarefas [T] há, geralmente, uma ou mais técnicas aceitas e reconhecidas institucionalmente. Essa técnica pode ser determinada pelos atores da instituição, mas não necessariamente existente/aceita em outras instituições. Vejamos um exemplo apresentado pelo próprio Chevallard, a saber:

\footnotetext{
Assim, podemos determinar o sinal do binômio $a x+b$ escrevendo esta expressão na forma $\mathrm{a}[\mathrm{x}-(-\mathrm{b} / \mathrm{a})]$, o que nos permite uma conclusão com um pequeno argumento: $2-3 \mathrm{x}=-3(\mathrm{x}-2 / 3)$ é negativo se $\mathrm{x}>2 / 3$, positivo para $\mathrm{x}<2 / 3 ; 5 \mathrm{x}+3=5[\mathrm{x}-(-0,6)]$ é positivo para $\mathrm{x}>-0,6$, negativo para $\mathrm{x}<-0,6$; etc. Mas ensinar/efetuar esta operação desta forma, praticamente desconhecida dos estudantes secundários franceses de hoje, certamente seria alvo de uma avalanche de críticas. (CHEVALLARD, 1999b, p. 224. Tradução nossa).
}

A execução de uma tarefa, ou tipo de tarefa, em princípio, supõe adoção de determinada técnica, este par é entendido então como um bloco prático-técnico $[\mathrm{T}, \tau]$. 


\subsection{2 - Bloco tecnológico-teórico (logos)}

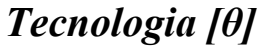

No contexto da TAD, Tecnologia, representada pela letra grega theta $[\theta]$, trata do discurso que interpreta e justifica a técnica. É importante destacar que a Tecnologia aqui tratada não traz o mesmo sentido cotidianamente enraizado. Aqui, Tecnologia é visto como um discurso racional que busca esclarecer e clarificar determinada técnica, busca justificar seu uso/eficiência. Conforme ressalta Cruz (2005), Tecnologia busca, dentre suas atribuições, tornar inteligível a técnica, assegurar seu êxito e favorecer, dentro do possível, o surgimento de novas técnicas.

Desse modo, $\theta$ visa o tripé: Justificativa - Explicação - Produção de novas Técnicas. Justificação, no sentido de garantir que uma dada técnica permita realizar as tarefas $[\mathrm{t} \in \mathrm{T}]$. Explicação, no sentido de tornar inteligível a técnica, expondo porque a técnica é correta. Produção de novas técnicas, a partir de tecnologias que estão associadas a poucas ou a nenhuma técnica (CHEVALLARD, 1999).

A tecnologia que permite explicar, por exemplo, o cálculo da quantidade de calor (Q) absorvido por um corpo em função da sua massa, variação de temperatura e do seu calor específico, remete à primeira lei da termodinâmica, ou seja, a variação da energia interna $(\Delta \mathrm{U})$ de um sistema é igual à diferença entre o calor e o trabalho $(\mathrm{W})$ trocados pelo sistema com o meio exterior, $\Delta U=Q-W$ (para sistemas fechados). O conceito de torque $(\vec{\tau})$ é outro exemplo de tecnologia que possibilita melhor compreender e justificar a adoção de determinadas técnicas, como no caso de uma pessoa que usa um cano para aumentar a extensão do cabo da chave de roda no intuito de facilitar a retirada dos parafusos. Essa técnica possibilita aumentar o braço de alavanca ( $\vec{r}$, distância entre o eixo de rotação e ponto de aplicação da força), que é diretamente proporcional ao torque. Assim, o torque resultante de uma força $(\vec{F})$ constante aplicada em um determinado ponto do cano pela pessoa para girar o parafuso, será tão menor quanto for a distância entre esse ponto e o eixo de rotação (dependendo do ângulo formado entre essas duas grandezas), determinado pela expressão vetorial $\vec{\tau}=\vec{r} \times \vec{F}$.

Segundo Chevallard, em uma instituição [I], independente dos tipos de tarefas e tarefas relativas, um tipo de tarefa sempre é acompanhada de pelo menos um vestígio de 
tecnologia $[\theta]$, ocorrendo, em muitos casos, a presença de elementos tecnológicos integrados à técnica. Vejamos::

Assim ocorre tradicionalmente em aritmética elementar, na qual o mesmo discurso tem uma dupla função, técnica e tecnológica, na medida em que permite tanto encontrar o resultado exigido (função técnica) como justificar que este é o resultado esperado (função tecnológica), como quando alguém diz: 'Se 8 pirulitos custam 10 Francos, 24 pirulitos, são 3 vezes 8 pirulitos, custarão 3 vezes mais, logo 3 vezes 10 Francos'. (CHEVALLARD, 1999b, p. 224. Tradução nossa).

No que tange às atividades de Robótica Educacional no ensino de Física, essa observação da existência de ao menos um vestígio de tecnologia, ou seja, de um discurso o qual possibilite tornar inteligível a técnica, expondo porque ela é eficaz/funciona, para nós se torna de grande importância. Como não estamos interessados apenas na execução da tarefa, e sim que o discente seja capaz de explicar e discutir o processo que está realizando em termos de teoria e conceitos da física, a TAD nos auxilia de modo a evidenciar e interligar esses fatores, conectando o bloco prático-técnico com o tecnológico-teórico.

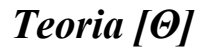

O discurso tecnológico que contém afirmações, mais ou menos explícitas, a partir do qual se pode perguntar os por quês. Assim, passa-se para um nível superior de justificaçãoexplicação-produção, em que a Teoria, representada na TAD pela letra $\boldsymbol{\Theta}$, retoma, em relação a tecnologia, o papel em que esta última diz respeito a técnica (CHEVALLARD, 1999).

A teoria compreende um segundo nível de validação da atividade, ou melhor, apresenta uma explicação e justificativa da tecnologia que compreende a adoção de uma técnica, sua solidez e persistência, adotada para realizar determinada tarefa. Tecnologia e Teoria compõem, assim, o bloco tecnológico-teórico $[\theta, \Theta]$, estritamente ligado ao 'saber'. De acordo com Zanardi (2013, p. 43),

[...] a tecnologia que explica a razão de a técnica da equação de Gauss para espelhos esféricos funcionar é a semelhança de triângulos e as leis da reflexão; já a tecnologia que determina a sua validade apenas para espelhos de pequena abertura é o fato de pequenos ângulos possuírem senos e tangentes praticamente de mesmo valor. Já as teorias $(\boldsymbol{\Theta})$ que justificam e explicam as tecnologias citadas (semelhança de triângulos, leis da reflexão e pequenos ângulos) são a Geometria plana da Matemática (daí esta área da Física ser comumente chamada de Óptica geométrica) e as equações do Eletromagnetismo. (ibidem).

Poder-se-ia pensar ainda em outros níveis de justificação, numa progressão que tende 
ao infinito, ou seja, teorias para explicar teorias que, por sua vez, apoiam outras teorias, etc. Contudo, de acordo com Chevallard (1999, p. 13, tradução nossa), "a descrição aqui apresentada em três níveis (técnica/ tecnologia/ teoria) é geralmente suficiente para dar conta da atividade que se quer analisar". Além disso, a justificação de uma determinada tecnologia é, em muitas instituições, tratada por simples transmissão para outra instituição, real ou suposta, considerada como detentora do discurso lógico que permeia essa justificação. Isso é identificado nos clássicos exemplos de declarações e situações como: "Mostramos em matemática ...", "O professor de física anunciou ...", "Se tem visto em geometria que ...". (ibidem).

\section{3 - Níveis de Praxeologias}

Uma Teoria $[\Theta]$ pode propiciar várias tecnologias $\theta_{\mathrm{j}}$, as quais podem vir a justificar e tornar inteligíveis Técnicas $\tau_{\mathrm{ij}}$ necessárias a Tipos de tarefas $\mathrm{T}_{\mathrm{ij}}$. Assim, é quase inevitável a ocorrência de junções entre os constituintes elementares, formando diferentes níveis de praxeologias.

Dentre essas junções ou níveis, temos a Praxeologia pontual $\left[\mathbf{T}_{\mathbf{i}}, \boldsymbol{\tau}, \boldsymbol{\theta}, \boldsymbol{\Theta}\right]$, elementar, significando que esta é uma Praxeologia formada ao redor de um único Tipo de tarefa [T]. Esse nível de praxeologia é mais raro de se verificar, uma vez que, em uma dada instituição, uma teoria propicia várias tecnologias, cada uma das quais, por sua vez, justificam e tornam inteligíveis várias técnicas, responsáveis pela realização dos tipos de tarefas. Quando uma organização praxeológica é obtida pela integração de um determinado conjunto de organizações pontuais, de tal maneira que todas elas podem ser explicadas utilizando o mesmo discurso tecnológico, trata-se então de Praxeologias locais $\left[\mathbf{T}_{\mathbf{i}}, \boldsymbol{\tau}_{\mathbf{i}}, \boldsymbol{\theta}, \boldsymbol{\Theta}\right]$. Em outras palavras, trata-se de vários 'saber-fazer' (práxis), justificados pelo mesmo 'saber' (logos).

De acordo com Barbé et al (2005, p. 237), no nível da educação básica, "para calcular o limite de funções racionais no infinito" ou "para demonstrar a existência do limite de uma função usando uma sequência numérica", pode estar na origem de organizações praxeológicas (nesse caso, matemática) pontuais. Porém, essa praxeologia pontual pode ser integrada em local, quando em torno do cálculo de limites de funções, sob a tecnologia álgebra de limites. $\mathrm{Ou}$, então, em diferentes organizações praxeológicas locais, dependendo do discurso tecnológico usado para descrever e justificar as técnicas e também sobre as diferentes organizações pontuais que estão ligadas entre si (ibidem). 
No caso do ensino de Física na educação básica, um exemplo clássico que podemos citar de praxeologia pontual envolve tipos de tarefas para as quais se faz uso de uma mesma técnica, como as de substituição de variáveis na equação (conhecida pelo sujeito) para se resolver "problemas" tradicionais fechados, tais como: Um móvel partiu do ponto A às 14h00min e chegou ao ponto B às 16h00min, sabendo que a distância entre A e B é de $40 \mathrm{~km}$, qual foi a velocidade média do móvel? Utilizando a expressão $x_{f}=x_{i}+v$. $\left(t_{f}-t_{i}\right)$. É possível encontrar a resposta para essa questão (determinar a velocidade média, $v$ ) apenas substituindo os valores informados para as variáveis tempo (t) e espaço (x). Com essa mesma técnica, compreendida pelo tecnologia que remete às leis de Newton, é possível resolver outras tarefas, principalmente aquelas que apresentem pequenas variações do "problema" anterior. Contudo, se a tarefa anterior envolver o tempo que decorre para que dois objetos se encontrem (dadas certas condições), não bastará apenas escrever a equação e substituir o valor das variáveis. Nesse caso, é preciso outra técnica (ainda inserida dentro de um mesmo bloco tecnológico) para se resolver a questão, a qual, por sua vez, demanda outras tarefas, como determinar a função horária da posição de cada móvel e, em seguida, igualar as duas expressões para, assim, poder determinar o tempo em que ocorrerá o encontro entre eles, resultando, portanto, em uma praxeologia local.

Outro exemplo de praxeologia pontual e local, comum em alguns exercícios das disciplinas introdutórias de Física nos cursos universitários, é o cálculo da função horária da velocidade, aceleração e/ou do tranco de um objeto (tipos de tarefas) por meio da derivação (técnica) da função horária da posição em relação ao tempo desse móvel. Dependendo do tipo de função (trigonométrica, polinomial, logarítmica, etc.), uma mesma técnica de derivação (compreendida dentro da tecnologia cálculo numérico) é suficiente para resolver todas essas três tarefas, configurando-se numa praxeologia pontual. Porém, se for necessário determinar a função horária da velocidade, mas só foi fornecido a função horária da aceleração, outra técnica será necessária (dentro da mesma tecnologia), nesse caso, calcular a integral indefinida da função dada, originando, assim, a praxeologia local.

Há uma espécie de junção entre uma organização e outra, as organizações pontuais vão assim se agregar, primeiramente em organizações locais $\left[T_{i}, \tau_{i}, \theta, \Theta\right]$, centradas em uma tecnologia própria, em seguida em Praxeologias regionais $\left[\mathbf{T}_{\mathbf{i j}}, \boldsymbol{\tau}_{\mathbf{i j}}, \boldsymbol{\theta}_{\mathbf{j}}, \boldsymbol{\Theta}\right]$, formadas no entorno de uma teoria $\boldsymbol{\Theta}$ que promove múltiplas tecnologias $\left[\boldsymbol{\theta}_{\mathbf{j}}\right]$ (CHEVALLARD, 1999). Podemos citar como exemplo de organização regional a segunda lei de Newton, ao afirmar que a força externa resultante que atua sobre um corpo, em um referencial inercial, 
corresponde a derivada do momento linear em função do tempo. Essa teoria implica o desdobramento de múltiplas tecnologias, como expressões da variação do momento linear, impulso de uma força que age em um intervalo de tempo, aceleração e velocidade de um corpo sob certas condições, dentre outras, gerando várias técnicas para efetuar diferentes tipos de tarefas.

Um quarto nível, formado por uma organização praxeológica complexa e denominado de Praxeologia Global $\left[\mathbf{T}_{\mathbf{i j k}}, \boldsymbol{\tau}_{\mathbf{i j k}}, \boldsymbol{\theta}_{\mathbf{i k}}, \boldsymbol{\Theta}_{\mathbf{k}}\right.$ ], pode também ser verificado quando se reúnem, em uma dada instituição, várias organizações regionais correspondentes as várias teorias $\boldsymbol{\Theta}_{\mathbf{k}}$. As áreas e linhas de pesquisa (física de partículas, astrofísica estelar, física de plasmas, dentre outras) e disciplinas (termodinâmica clássica, mecânica clássica, introdução ao eletromagnetismo, etc.) se configuram em praxeologias globais, uma vez que se apoiam em uma gama de teorias que, por sua vez, implicam em múltiplas tecnologias e técnicas na realização de inúmeros tipos de tarefa.

Nota-se que a passagem de uma praxeologia pontual para uma local centra-se na tecnologia $(\boldsymbol{\theta})$, da mesma maneira que a subsequente praxeologia regional terá a teoria $(\boldsymbol{\Theta})$ como primeiro plano. Isso é importante destacar pois, em ambos os casos, o bloco tecnológico-teórico $[\boldsymbol{\theta}, \boldsymbol{\Theta}]$ ganha mais visibilidade, com possibilidade de ter melhor compreensão e ação sobre o bloco prático-técnico [ $\left.\mathbf{T}_{\mathbf{i}}, \boldsymbol{\tau}\right]$, (saber-fazer) (ibidem).

Portanto, de acordo com o processo de institucionalização, uma OP didática pode ganhar abrangência e deixar de ser pontual (constituída ao redor de um tipo de tarefas e problemas, resolvidos por aplicação de uma única técnica) e passar a ser local (quando se adota uma mesma tecnologia para compreender múltiplas técnicas e tarefas) e até mesmo uma OP regional (centrada numa mesma teoria) ou global (centradas em múltiplas teorias). Desse modo, o processo de estudo vai cada vez mais "abrindo" a OP existente (didática, física, matemática, química, biológica, artesã, industrial, etc.), modificando-a de modo a enriquece-la, simplifica-la, etc.

Além disso, é importante destacar que uma OP pode não ser completa, ou seja, não apresentar todos os elementos $[\mathrm{T}, \tau, \theta, \Theta]$ que a compõem em uma determinada Instituição [I], eles podem ser desconhecidos, inexistentes ou até mesmo não reconhecidos.

Por exemplo: o camponês que abre um buraco na terra da fazenda, que trabalha para fincar uma estaca, pode ser compreendido como uma organização praxeológica. Nesse caso, o tipo de tarefa remete a "fincar estaca", que demanda uma determinada tarefa, ou seja, "abrir 96 
buraco em local determinado para fincar a estaca". Em seguida, não é qualquer técnica que possibilita cumprir essa tarefa de forma eficaz, ou seja, deve-se saber qual ferramenta apropriada para esse trabalho e como manuseá-la. Ao escolher um enxadão e não uma enxada para abrir o buraco, bem como ao manuseá-lo sem elevar a ferramenta para além do plano vertical de sua cabeça, deixando o enxadão cair basicamente sobre a ação da gravidade, o camponês está se valendo de técnicas, reconhecidas na instituição, que lhe permitem cumprir de forma eficiente a tarefa que lhe foi designada. Nesse caso, o camponês e a instituição em que está inserido, a fazenda ou o meio rural, por exemplo, podem não ter conhecimento do bloco tecnológico-teórico contido em outra instituição que justifique essa técnica, seu discurso pode remeter a comunidade que "sempre fez assim", ou ainda que "é um jeito de ter menos trabalho". Porém, em outra instituição, na Física, por exemplo, podemos identificar elementos da mecânica clássica, como o conceito de energia potencial gravitacional e trabalho, que permitem melhor compreender e justificar as técnicas adotadas na realização dessa tarefa, compondo, assim, o boco tecnológico-teórico. Outro exemplo é o caso da bailarina ou patinadora que fecha os braços e se abaixa para aumentar sua velocidade de giro. Ela e seu treinador podem saber muito bem qual(is) técnica(s) adotar para efetuar essa tarefa, porém, podem desconhecer completamente a noção de momento angular e leis de conservação, ou seja, o bloco tecnológico-teórico que compreende o por quê a ação "fechar os braços e se abaixar" causou o aumento da velocidade de giro dela. Na própria ciência isso também se verifica, por exemplo, na época dos primeiros experimentos do físico e químico Michel Faraday que implicaram no desenvolvimento do motor elétrico, não se conheciam os mecanismos teóricos e os formalismos matemáticos do eletromagnetismo que permitissem melhor compreender seu funcionamento e otimizar as técnicas envolvidas, isso só ocorreu anos mais tarde através dos trabalhos de James Clerk Maxwell (1831-1879). O cruzamento de plantas e animais com objetivo de aperfeiçoar determinadas espécies é outro exemplo em que a Organização Praxeológica não estava ainda completa. Esse tipo de tarefa realizada pelo homem, obter espécies mais aperfeiçoadas que seus antecessores, já ocorria milhares de anos antes das primeiras noções de genética. Porém, somente com o avanço da biologia molecular, a partir do século passado, foi possível melhor compreender os mecanismos por detrás desse processo, além de possibilitar o surgimento de novas técnicas de melhoramento genético das espécies em interesse, a fim de obter produtos úteis ao homem e ao meio ambiente. O inverso também é verdadeiro, ou seja, possuir um bloco tecnológico-teórico bem desenvolvido, mas que não permite efetuar determinada tarefa, seja pela falta de técnicas, ferramentas e/ou 
materiais adequadas. Um exemplo que podemos apresentar nesse aspecto é a fusão nuclear. A física de partículas hoje está desenvolvida ao ponto de compreendermos teoricamente bem os mecanismos que regem a fusão nuclear, como as que ocorrem no sol, por exemplo. Contudo, sua adoção para produção de energia elétrica de forma controlada e eficiente (tarefa) ainda é um desafio a ser vencido. Em outras palavras, a ciência possui um bloco tecnológico-teórico consistente sobre fusão nuclear, porém, dificuldades de ordem técnica não permitiram ainda efetuar a referida tarefa. Por fim, podem haver tipos de tarefas "proibitivas", ou seja, mesmo sendo teoricamente possíveis, a instituição não autoriza sua realização, como é o caso de determinadas pesquisas com células tronco e clonagem humana. A clonagem humana reprodutiva, por exemplo, é proibida em algumas instituições, seja por questões éticas, em razão de técnicas com baixa eficiência, seja por motivos religiosos.

Com isso, é interessante notar que as organizações praxeológicas são dinâmicas. Como bem aponta Rossini (2008, p. 31), "muitas delas envelheceram, quando seus componentes teóricos e tecnológicos perderam o brilho, a eficiência, quando deixaram de dar respostas satisfatórias para novos problemas. Assim, novas praxeologias surgem.”.

\section{4 - Relação entre indivíduo (X) e objeto (O) no processo de contextualização.}

$\mathrm{Na}$ TAD, um dos conceitos fundamentais é o de objeto (O) e existe há pelo menos um indivíduo. Os objetos podem ser abstratos (equações, símbolos, ideias, conceitos, leis, expressões matemáticas, poemas, etc.) ou concretos (ferramentas, maquinários, estruturas físicas, animais, minerais, plantas, pessoas, etc.). "Em particular, qualquer trabalho que seja, qualquer produto intencional da atividade humana, é um objeto." (CHEVALLARD, 2006, p.1, tradução nossa).

Outro ponto fundamental da teoria é a relação pessoal que um indivíduo $(\mathbf{X})$ tem com o objeto $(\mathrm{O})$, sistema esse expresso por $\mathbf{R}(\mathbf{X}, \mathbf{O})$. Podemos afirmar que o objeto existe para o indivíduo, se as relações pessoais $\mathrm{R}(\mathrm{X}, \mathrm{O})$ "não está vazio", ou seja, $\mathbf{R}(\mathbf{X}, \mathbf{O}) \neq \boldsymbol{\emptyset}$. Interessante observar que, ao longo do tempo, o sistema de relações pessoais evolui, isso implica dizer que objetos que não existem para o indivíduo podem começar a existir, outros deixam de existir enquanto outros se modificam. Essas mudanças na relação $\mathrm{R}(\mathrm{X}, \mathrm{O})$ podem ser provocadas pelas Instituições (I) em diferentes espaços sociais como, por exemplo, na família ou numa sala de aula (incluindo-se aí duas posições-chave que são as de professor e de aluno) (ibidem).

Dessa forma, podemos pensar no processo de contextualização como um meio para 
alterar a relação $\mathrm{R}(\mathrm{X}, \mathrm{O})$, ou até mesmo para criar uma em caso inexistente. Se isso não ocorrer em algum momento, podemos afirmar que a contextualização não foi bem sucedida. Em outras palavras, quando se tem objetos que estão imersos em determinadas organizações praxeológicas (física, matemática, química, didática, artesã, industrial, etc.), mas com os quais o indivíduo ainda apresenta apenas relações tímidas ou inexistentes, estas podem ser criadas, atualizadas e enriquecidas através do processo de contextualização, o qual permite ao indivíduo "revisitar" e perceber o mundo ao seu redor de maneira diferenciada, com novas perspectivas e possibilidades de ação em comparação ao que se lhe apresentava antes.

Imaginemos um aluno que não conhece o princípio de funcionamento do motor de um automóvel. A relação que o indivíduo (X), nesse caso, o aluno tem com o objeto $(\mathrm{O})$, o carro, pode ser complementada por meio de atividades experimentais didáticas, por exemplo, atividades nas quais se discutam os processos de combustão interna, utilizando modelos e protótipos, explorando, assim, conceitos da física como trabalho, eficiência, energia, calor, temperatura, além de questões de ordem social e ambiental, como poluição e emissão de $\mathrm{CO}_{2}$, consumismo, mobilidade urbana, dentre outras. Dessa forma, espera-se que o aluno possa ter novos olhares e capacidade de ação sobre os objetos inseridos naquela atividade humana. Obviamente que as ações do indivíduo para modificar o objeto dependem de sua intenção e das circunstâncias, mas isso não significa que sua relação com o objeto permaneça inalterada.

As avaliações tradicionais, via testes e provas com questões específicas envolvendo o objeto estudado, são comumente utilizadas para sondar se tal relação foi modificada ou criada após um processo didático qualquer. Entretanto, esta forma avaliativa é, geralmente, focada apenas em conteúdos disciplinares e nas relações de curto prazo que o indivíduo tem com aquele objeto estudado. É preciso ter em mente que tais relações são muito mais complexas e extrapolam o conteúdo disciplinar, indo além da sala de aula e podem se modificar em tempos variados.

Portanto, apesar das avaliações tradicionais focarem na relação do indivíduo com um objeto específico, geralmente conceitual e disciplinar, o indivíduo pode alterar ou até mesmo criar, a longo ou curto prazo e fora da sala de aula, relações com outros objetos $\left(\mathrm{O}_{\mathrm{n}}\right)$ após passar por aquele processo de estudo que acarretou essa avaliação. Desse modo, o indivíduo pode gerar o que denotamos de $\mathbf{R}\left(\mathbf{X}, \mathbf{O}_{\mathbf{n}}\right) \neq \boldsymbol{\emptyset}$. Por exemplo, pode-se esperar que um aluno domine a noção de inércia e que no processo avaliativo ele resolva questões e efetue corretamente os cálculos necessários. Entretanto, sua relação com o objeto "inércia" ( $\left.\mathrm{O}_{\text {inércia }}\right)$ 
pode ir além desse aspecto formal e pragmático. Tal relação pode envolver experiências reais que o indivíduo teve ou venha a ter como, por exemplo, a frenagem brusca de um ônibus com passageiros. Nesse caso, a relação $\mathrm{R}\left(\mathrm{X}, \mathrm{O}_{\text {inércia }}\right)$ pode auxiliar o indivíduo a melhor compreender essa situação de frenagem, olhar para ela de uma outra perspectiva, expresso assim por $\mathbf{R}\left(\mathbf{X}, \mathbf{O}_{\text {inércia }}\right) \Leftrightarrow \mathbf{R}\left(\mathbf{X}, \mathbf{O}_{\text {frenagem }}\right)$.

Por fim, é interessante notar também que a própria relação $\mathrm{R}\left(\mathrm{X}, \mathrm{O}_{\text {inércia }}\right)$ se altera quando o indivíduo faz "pontes" com outros objetos (por exemplo: frenagem, colisão inelástica, aceleração, dentre outros), contidos em diferentes cenários e situações, ampliando, portanto, sua compreensão e percepção sobre o objeto "inércia". Assim, propomos que um dos papéis fundamentais do processo de contextualização nessa perspectiva é o de, por meio de relações do indivíduo com os objetos da OP didática, alterar ou criar relações com outros objetos contidos em uma dada realidade (uma prática social de referência) a qual se deseja contextualizar, ou seja, $\mathbf{R}(\mathbf{X}, \mathbf{O}) \Leftrightarrow \mathbf{R}\left(\mathbf{X}, \mathbf{O}_{\mathbf{n}}\right)$.

Uma das formas que encontramos para auxiliar esse processo de contextualização, no qual se espera que o indivíduo seja capaz de mudar ou criar relações com os objetos ao seu redor, é através da análise da atividade didática numa perspectiva de Verossimilhança Praxeológica conforme discutido a seguir, trata-se do desenvolvimento de uma "adequação" teórica da TAD.

\section{5 - Análise de atividades por níveis de ressonância: a noção de Verossimilhança Praxeológica (VP).}

Tomando como base o aspecto estrutural da TAD, elaboramos instrumentos teóricos que podem auxiliar a análise e o desenvolvimento de atividades com potencial para fomentar o processo de contextualização através de uma OP didática. Buscamos investigar possíveis correlações entre objetos (ressonância) presentes tanto na atividade didática quanto entre ela e a realidade que se deseja contextualizar. Como essa "realidade" contém práticas sociais de referência, com práxis e logos próprios, podemos afirmar que se trata de uma OP de referência. Constatamos que, em uma OP didática qualquer que visa contextualizar uma determinada OP de referência, pode haver dois níveis de ressonância: um interno e outro externo.

A ressonância interna indica que há uma comunicação/ diálogo entre o bloco práticotécnico com o tecnológico-teórico, uma praxeologia completa. Ela apresenta então 
correlações entre o fazer e os aspectos lúdicos com a teoria e conceitos físicos tratados na atividade, por exemplo: em um experimento para determinação do valor da aceleração da gravidade local (g), os alunos são convidados a construir um pêndulo simples de tamanho específico e determinar seu período de oscilação. Esse primeiro momento, construção do pêndulo e determinação do período, pode configurar no bloco prático-técnico da OP didática. Entretanto, para se determinar o valor da aceleração da gravidade é necessário também um bloco tecnológico-teórico, em que expressões do movimento oscilatório estão em jogo. Portanto, as ações executadas no bloco prático-técnico dessa OP didática serão exploradas diretamente no bloco tecnológico-teórico, existindo assim uma ressonância entre a práxis e o logos. Não haveria sentido, por exemplo, em calcular a velocidade tangencial do pêndulo no bloco prático-técnico, uma vez que tal informação não é diretamente utilizada no bloco tecnológico-teórico da OP didática para se determinar o valor da aceleração da gravidade. Ou, então, adotar um bloco tecnológico-teórico que não permite resolver o problema em questão como, por exemplo, utilizar dados do comprimento e período de oscilação do pêndulo simples e querer calcular "g” por meio do princípio da óptica geométrica.

Todo esse processo poderia ainda ser invertido, ou seja, partir do logos para então entrar na práxis, partir de uma teoria e/ou tecnologia e investigar as técnicas por ela(s) promovida(s) e os tipos de tarefas capazes de serem realizadas (como ocorre tradicionalmente nos cursos de Física universitários e da educação básica, ou seja, se ensina primeiro a teoria para depois se verificar os tipos de tarefas possíveis de serem resolvidos). Portanto, como no exemplo anterior, deve existir uma ressonância interna na OP didática entre o bloco tecnológico-teórico com o prático-técnico de tal forma que o problema possa ser plenamente investigado e solucionado em algum momento do processo de estudo.

Já a ressonância externa, indica que há correlações diretas ou indiretas entre objetos da OP didática e da OP de referência. A ressonância externa esta intimamente relacionada ao processo de contextualização intencionado na OP didática, por exemplo: ao se discutir em sala de aula o funcionamento das usinas hidrelétricas, a instituição escolar pode se valer de atividades experimentais de baixo custo e adotar a mesma técnica presente nessas usinas para geração de energia elétrica, ou seja, acionar turbinas (geradores) através da força de quedas ou fluxos d'água. Com um pequeno motor elétrico (do tipo encontrado em carrinhos de controle remoto) e materiais recicláveis (como garrafas PET, tampas de potes, caixas de suco, etc.), é possível construir uma maquete funcional de usina hidrelétrica, a qual se apoia na mesma técnica de uma usina "real" para gerar eletricidade. Essa maquete poderia aproveitar o fluxo 
d'água de uma torneira para girar as hélices (do tipo moinho d'água) acopladas ao motor, que funciona como um dínamo, gerando, assim, energia elétrica. Nesse caso, é interessante notar que o bloco tecnológico-teórico, que permite melhor compreender a realização desse tipo de tarefa através da técnica adotada, é praticamente o mesmo. A turbina (no caso das usinas hidrelétricas "reais") e o motor (no caso da maquete) transformam energia mecânica (queda d'água) em elétrica através da indução eletromagnética provocada pelo movimento do gerador (motor elétrico ou turbina). Apesar da corrente elétrica gerada pela maquete ser uma corrente contínua, diferente da corrente alternada produzida nas usinas, o tipo de tarefa (produzir energia) pode ser considerada a mesma e há também correlações em termos de técnicas, tecnologias e teorias entre ambas. Em outras palavras, identifica-se na maquete, desenvolvida em sala de aula para se discutir o funcionamento de uma usina hidrelétrica, que há uma ressonância externa, entre a OP didática e a OP de referência, em termos dos elementos praxeológicos $\mathrm{T}, \tau, \theta, \Theta$. Contudo, há outros tipos de tarefas que são particulares de cada OP, como a própria construção da usina e/ou da maquete, que demanda técnicas específicas e outras tarefas (represar a água, construir barreiras, desviar fluxos d'água, etc.).

Quando identificada uma ressonância externa, como no exemplo citado anteriormente, interpretamos existir a ocorrência do que nós denominamos de Verossimilhança Praxeológica. Dessa maneira, a Verossimilhança Praxeológica (VP) remete aos elementos praxeológicos (todos ou parcialmente) que são, em algum nível, similares entre duas organizações praxeológicas distintas. As ilustrações seguintes (Figura 5 e Figura 6) podem oferecer uma maior clareza a respeito dessa noção que desenvolvemos.

A Figura 5 apresenta uma situação de Verossimilhança Praxeológica quando ocorre a existência de uma interseção de dois conjuntos. Nesse caso, nota-se a existência de uma teoria, uma tecnologia e uma técnica contidas tanto na OP de referência quanto na OP didática. Entretanto, se um determinado elemento praxeológico, uma tarefa ou tipo de tarefa, por exemplo, não é idêntico nos dois conjuntos, mas apresenta uma similaridade, podemos afirmar se tratar de uma Verossimilhança Praxeológica por correspondência (Figura 6). 


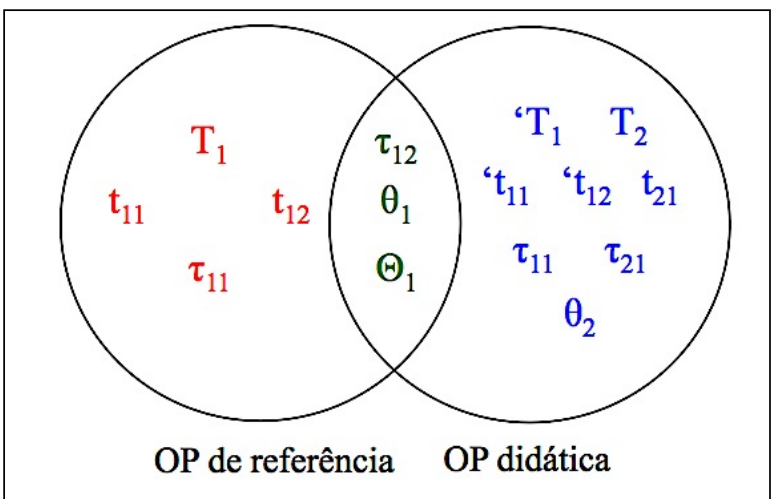

Figura 5 - Verossimilhança Praxeológica por interseção.

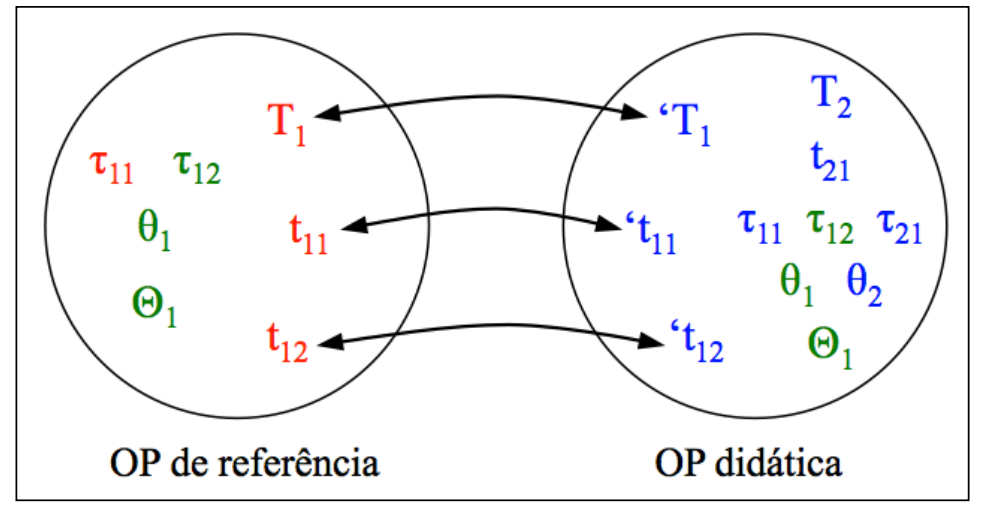

Figura 6 - Verossimilhança Praxeológica por correspondência.

Assim, é possível investigar de maneira estruturada e organizada quais elementos praxeológicos são, de fato, explorados na sequência didática que visa "contextualizar" uma determinada situação/ atividade humana no âmbito escolar. Em outras palavras, pode-se analisar quais tarefas, técnicas, tecnologia e/ou teorias identificadas da prática social de referência (que fundamentam a contextualização), de fato, estão presentes (de modo explícito ou não) na OP didática.

No exemplo anterior da maquete de uma usina hidrelétrica, tanto o tipo de tarefa e técnica quanto a tecnologia e a teoria correspondem a uma $V P$ por interseção, uma vez que se identificam elementos praxeológicos comuns nas duas OP (didática e de referência). Já a construção da usina propriamente dita no formato de maquete, identifica-se apenas uma $V P$ correspondência entre o sistema construído na OP didática e na OP de referência.

Podemos ilustrar ainda a aplicação desses dois conceitos (VP por interseção e correspondência) tomando como exemplo uma ponte levadiça (Figura 7). Na OP didática, por exemplo, pode-se construir uma ponte levadiça em tamanho reduzido e acionada por manivela fazendo uso de kits de robótica (Figura 8). 
Uma das questões que se pode trabalhar na OP didática refere-se a caixa de redução, contendo engrenagens para reduzir a velocidade de rotação e aumentar o torque disponível. A caixa de redução utilizada na ponte da OP didática (Figura 8) não é a mesma utilizada nas atuais pontes levadiça da OP de referência (Figura 7), uma vez que é acionada manualmente através de uma manivela, construída com hastes de metal perfurado e em tamanho reduzido, dispostas de maneira própria para atender as necessidades da OP didática.

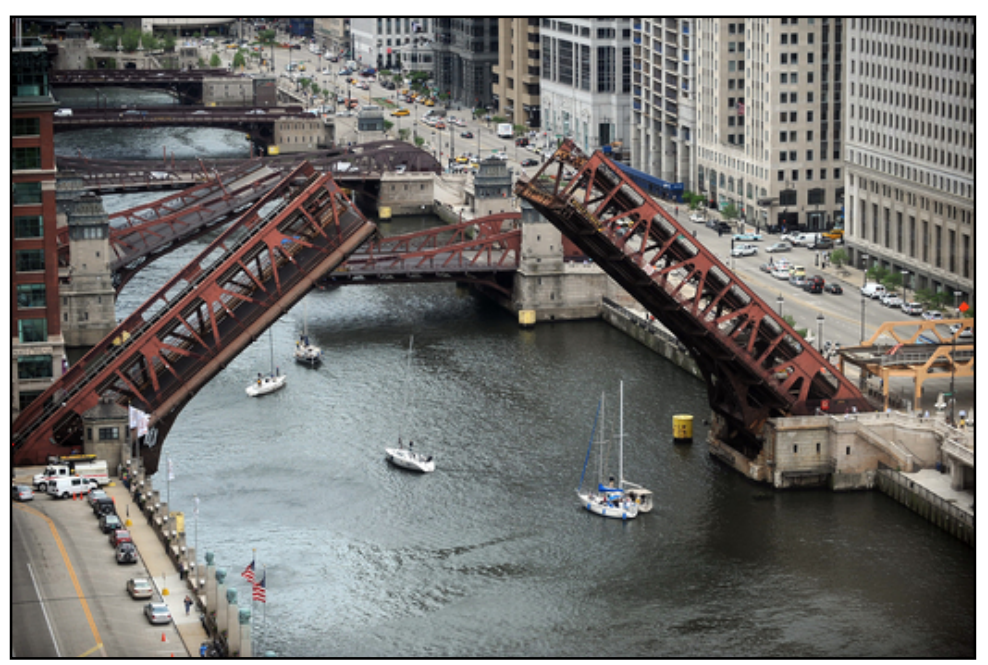

Figura 7 - Ponte do rio da cidade de Chicago, EUA. | Richard A. ChapmanSun-Times. Fonte: http://blogs.suntimes.com/news/chicago river/ Acesso em 24 de fevereiro de 2014.

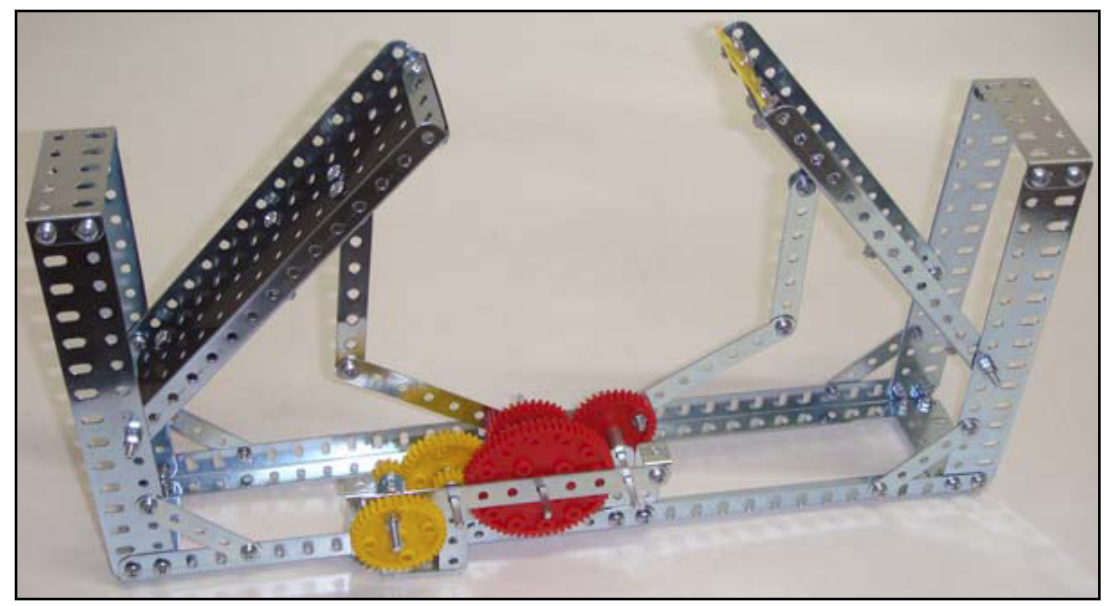

Figura 8 - Ponte levadiça em construção com kits de robótica educacional (Modelix Robotics). Fonte: http://www.leomar.com.br/modelix/ Acesso em 24 de fevereiro de 2014.

Nesse caso, apesar da estrutura presente na OP didática e na OP de referência corresponderem a uma ponte levadiça, a ponte desenvolvida na OP didática não serve para executar exatamente a mesma tarefa da OP de referência. Assim, há apenas o que denominamos de uma Verossimilhança Praxeológica por correspondência no que tange a 
técnica, uma vez que apresentam mecanismos e procedimentos apenas similares (não idênticos) utilizados nas duas OP (como a caixa de redução). Por outro lado, o princípio físico de funcionamento da caixa de redução presente em uma ponte levadiça, é exatamente o mesmo para os dois casos, não importando a magnitude da tarefa realizada, assim, há uma Verossimilhança Praxeológica por interseção no que tange a tecnologia e a teoria. Nesse caso, é possível compreender o funcionamento desse mecanismo, tanto na OP de referência quanto na OP didática, através de um mesmo bloco tecnológico-teórico como, por exemplo, através das relações de transmissão de engrenagens e de decomposição das forças.

Por fim, é interessante notar que a noção de Verossimilhança Praxeológica pode fomentar o desenvolvimento de atividades por meio de outras abordagens e estratégias didático-pedagógicas, tais como experimentação, CTSA (Ciência, Tecnologia, Sociedade e Ambiente), Aprendizagem Centrada em Eventos (ACE), simulações computacionais, objetos de aprendizagem, educação não-formal, dentre outros. Objetivando sempre explorar na OP didática elementos praxeológicos identificados na OP de referência que se deseja contextualizar. Por exemplo: a água de lastro é um importante mecanismo (técnica) que os navios e submarinos (OP de referência) utilizam para manter sua profundidade e operação (podemos considerar como tarefas a serem realizadas). O navio ou submarino capta a água do mar e as conserva em suas comportas em quantidade regulável de acordo com a profundidade que se deseja manter a embarcação. Dois principais conceitos físicos, empuxo e centro de gravidade, compõem o bloco tecnológico-teórico que permite melhor compreender a adoção e eficiência da técnica (água de lastro) utilizado por essa OP. Por meio de um ludião (Figura 9), é possível efetuar experimentos simples para explorar essa técnica e discutir o bloco tecnológico-teórico envolvido (JESUS, MARLASCA \& TENÓRIO, 2007), compondo, assim, a OP didática. Apesar de ter uma tarefa própria (afundar um determinado objeto preso dentro de uma garrafa), configurando em uma $V P$ por correspondência, essa atividade possui técnica, tecnologia e teoria idêntica a da OP de referência, ou seja, apresenta uma $V P$ por interseção. 


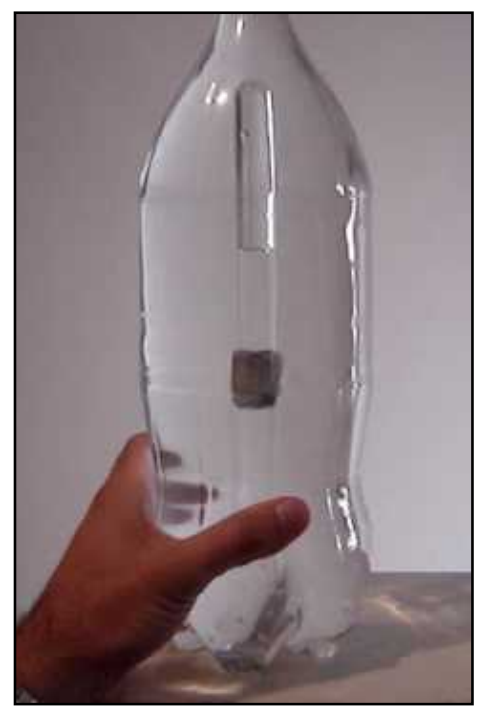

Figura 9 - Ludião.

Fonte: http://img.youtube.com/vi/1MmZCDCZB0Y/0.jpg Acesso em 10 de Janeiro de 2014.

Contudo, a água de lastro envolve graves riscos ambientais. Ao inserir a água do mar para dentro das comportas, aumentando o empuxo, várias espécies de organismos podem parar dentro dos tanques, desde microrganismos até peixes. Ao serem despejados de volta ao mar, esses organismos podem parar em locais distantes de seu habitat natural, podendo causar Bioinvasões e epidemias. Assim, a OP didática que contextualizou, através da $\underline{V P}$ por interseção, uma técnica aparentemente inocente, pode discutir os sérios danos ambientais que acarreta essa mesma técnica quando vista dentro da OP de referência. Desse modo, estratégias didático-pedagógico envolvendo CTSA e ACE podem ser adotadas nesse cenário, promovendo de modo direto processos de contextualização que podem modificar ou criar as relações do sujeito com os objetos ao seu redor, seja partindo de uma OP de referência ou da própria OP didática, desde que $\mathbf{R}(\mathbf{X}, \mathbf{O}) \Leftrightarrow \mathbf{R}\left(\mathbf{X}, \mathbf{O}_{\mathbf{n}}\right)$.

\section{6 - Aspecto funcional da TAD: os momentos didáticos.}

Ao pensarmos em uma organização praxeológica didática, podemos nos questionar sobre quais os principais tipos de tarefas que podem ocorrer (geralmente cooperativas) e em qual ordem, além de quais técnicas e tecnologias adotadas na sua execução e compreensão? Conforme aponta Chevallard (1999, p. 21), não podemos esperar que a (re)construção, no decorrer de um processo de estudo de uma organização praxeológica (matemática, por exemplo), se organize ela mesma de uma única maneira ou obedeça um único caminho e ordem cronológica. Entretanto, “constatamos sem dúvida que, qualquer que seja o caminho de 
estudo, certos tipos de situações estarão necessariamente presentes, mesmo que sejam de maneiras muito diferentes, tanto no plano qualitativo quanto no plano quantitativo." (ibidem). A essas situações é que Chevallard chama de momentos didáticos ou momentos de estudo pois, independente do caminho seguido, chega-se forçosamente a um momento onde o "gesto" (ou modo) de estudo é característico e deverá ser cumprido, por exemplo: o educando deverá "fixar" (pode ser entendido também como confirmar ou agrupar) os conceitos elaborados de acordo com a organização praxeológica em jogo, configurando-se, assim, como momento da institucionalização, onde deverá também se perguntar sobre o "significado" daquilo que foi construído até então, refletindo sobre o mesmo, "pondo em xeque" sua compreensão (momento da avaliação).

\begin{abstract}
A noção de momento não remete mais que, em aparência, à estrutura temporal do processo de estudo. Um momento, no sentido dado à palavra aqui, é em primeiro lugar uma dimensão em um espaço multidimensional, um fator em um processo multifatorial. Portanto, uma boa gestão de estudo exige que cada um dos momentos didáticos se realizem em bom tempo, ou mais exatamente, em bons tempos: pois um momento de estudo se realiza geralmente repetidas vezes na forma de uma multiplicidade de episódios que prorrompem no tempo. Este ponto de vista indica que a ordem, sobre os diferentes momentos didáticos, é em grande parte arbitrária, porque os momentos didáticos são em primeiro lugar uma realidade funcional de estudo, antes de ser uma realidade cronológica. (CHEVALLARD, 1999, pp. 21-22). Tradução nossa.
\end{abstract}

Ao todo, a TAD propõe a existência de seis momentos de estudo ou momentos didáticos, os quais não obedecem necessariamente a uma ordem cronológica, podendo ocorrer de maneira simultânea e em diferentes ocasiões do processo de estudo, a saber: 1) Primeiro encontro com a organização praxeológica que está em jogo; 2) Momento da exploração do tipo de tarefas e da elaboração inicial de uma técnica relativa a este tipo de tarefa; 3) Constituição e desenvolvimento do bloco tecnológico-teórico relativo à técnica e ao tipo de tarefa proposta pela organização; 4) Momento de trabalho da técnica, visando vivenciá-la e aprimorá-la o quanto possível; 5) Momento da institucionalização, visa precisar o que, de fato, pertence e é de domínio da organização; 6) Por fim, o momento da avaliação, em que se deve "fazer um balanço", um momento de reflexão em que se examina o que foi "aprendido" daquela OP. Conforme aponta Chevallard (1999),

O modelo dos momentos de estudo tem, para o professor, dois grandes tipos de emprego. Em primeiro lugar, constitui uma grade para a análise de processos didáticos. Em segundo, permite levantar claramente o problema da relação dos diferentes momentos de estudo. Por exemplo, como realizar concretamente o primeiro encontro com tal organização matemática? Com que tipo de tarefas? Como conduzir o estudo exploratório de um dado tipo 
de tarefas? Como levar a cabo a institucionalização? Como realizar o momento da avaliação? São questões que se levantam ao professor e as que se pode responder de modo geral: criando as situações didáticas adequadas. Esta exigência, que indicamos somente aqui, é de fato muito mais complicada quando o professor é tanto o diretor quanto o ator de situações didáticas das quais, as mais das vezes, é também o designer. (ibidem, pp. 2526). Tradução nossa e grifo do autor.

Desse modo, ao se interrogar sobre "como realizar concretamente o primeiro encontro com uma tal organização?", "como concluir o estudo exploratório de um dado tipo de tarefas?" e "como levar a cabo a institucionalização?", abre possibilidade para o corpo docente e pesquisadores em geral desenvolverem sequências de ensino consoantes com seus objetivos didáticos. Assim, no caso de atividades didáticas que visam a contextualização no ensino de Física por meio da robótica educacional, a análise dos momentos de estudo podem contribuir também para investigar o quanto elementos praxeológicos da prática social de referência estão presentes e como são trabalhados (tanto pelo professor quanto pelo educando) na OP didática. Por exemplo: a exigência de uma determinada técnica na OP didática para o cumprimento de uma tarefa pode não ser adequada para um grupo de alunos ou apresentar complicações que necessitam de um maior tempo para seu pleno domínio (expressões matemáticas e cálculos complexos e/ou em demasia; montagem minuciosa com grande quantidade de peças e procedimentos; programação computacional com algoritmo envolvendo muitos elementos ou partes, etc.). Nesse caso, a análise dos momentos de estudo deve revelar que houve um predomínio do momento de trabalho da técnica (devido ao tempo de permanência dos sujeitos nesse momento de estudo), prejudicando o momento tecnológico teórico ou outro qualquer, dado o conjunto fixo de aulas/ horas disponíveis para realização da atividade. Outro exemplo remete as exposições itinerantes, ou seja, a leitura de um painel informativo (ação essa que pode se configurar como o momento do primeiro encontro com o problema ou tarefa da $\mathrm{OP}$ ) geralmente não é tão atrativa e/ou executada em comparação com o momento de trabalho com a técnica, no qual o visitante apresenta algum tipo de interação com aquele cenário que lhe é apresentado. É o caso do gerador de Van de Graff, onde o visitante toca uma esfera metálica e os cabelos ficam "arrepiados", ou o caso da bicicleta com gerador elétrico, na qual o visitante pedala para gerar energia elétrica por meio de um dínamo que alimenta alguns aparelhos elétricos, ou ainda, no caso dos aparatos que causam ilusão de óptica, dependendo da forma (técnica) como são acionados. Esses são alguns dos típicos exemplos que ilustram bem a questão cronológica dos momentos de estudo, ou seja, passar primeiramente pelo momento de trabalho com a técnica para depois ter o momento do primeiro encontro ou outro qualquer. 
Os momentos de estudos são tratados como sendo as vivências necessárias para que um indivíduo consiga dominar um determinado conhecimento. A seguir, especificamos cada um desses momentos.

\section{Momento do primeiro encontro}

Representa o primeiro contato que um grupo de estudo ou indivíduo tem com a organização e objeto em jogo. Tal encontro pode ocorrer de várias formas, como, por exemplo, o contato com um tipo de problema (ou tipo de tarefas) que ele não sabe resolver de antemão contido nessa organização. É interessante notar que, por meio de uma narração com valor informativo e com indagações sobre o mundo, esse momento pode apresentar uma problemática cultural mimética, em que o objeto encontrado aparece em primeiro lugar, existindo por toda parte e em algumas práticas sociais, porém, o indivíduo tem somente relações fictícias com o objeto, não sendo mais do que uma representação. Assim, se segue um sub momento mimético no qual, mediante a manipulação efetiva do objeto, se supõe que o estudante imite a prática.

Na versão mais exigente, o encontro cultural-mimético conduz em princípio à investigar e explicar - sob o modo discursivo - as razões de ser dos objetos assim encontrados, ou seja, os motivos pelos quais este objeto tem sido construído ou aqueles pelos quais, ao menos, persiste na cultura. (ibidem, p. 22). Tradução nossa e grifo do autor.

Outra forma de ocorrer o momento do primeiro encontro é por meio das situações fundamentais, nas quais o indivíduo manipula os objetos da organização em jogo e se afasta, na medida do possível, de toda referência de uma realidade preexistente, não os reduzindo a uma simples cópia das definições depositadas na cultura em geral, favorecendo, desse modo, os processos de modelização. Assim sendo,

É preciso, com efeito, que toda situação efetiva de primeiro encontro seja uma situação "umbilical". Em muitos casos, a definição do objeto por um sistema de situações fundamentais se encontra sub-repticiamente descartada em favor de encenar o objeto em algumas "atividades" que, apesar de algumas características culturais conservadas, não têm mais que uma relação bastante remota com suas razões de ser mais essenciais. De uma maneira mais geral, existem nas práticas didáticas correntes uma ampla gama de formas híbridas de primeiros encontros, onde uma referência cultural incompletamente assumida se alia, em graus variados, com uma introdução "em situação" mais ou menos adequada nos planos epistemológico e cognitivo. (ibidem, p. 23). Tradução nossa. 
Portanto, uma prática social de referência que envolve localizar objetos e estruturas no fundo do mar, por exemplo, contém situações (tarefas) que podem fomentar o momento do primeiro encontro. Assim, questões sobre quais os instrumentos utilizados para o cumprimento dessa tarefa, seu princípio de funcionamento e as tecnologias envolvidas, podem se configurar na problematização inicial, ou momento do primeiro encontro, no qual o estudante normalmente possui apenas relações "fictícias" com os objetos (sonar, ultrassom, navio, radar, etc.) daquela situação. No decorrer do processo de estudo, ao se questionar sobre a razão de ser desses objetos, o indivíduo entra em situações fundamentais que conduzem-no a propor definições e conceitos complexos, adequados à OP didática.

\section{Momento exploratório}

A partir do tipo de problema, ou tipo de tarefa que está sendo estudado, várias tarefas (do problema em questão) são trabalhadas. Este momento permite o surgimento de pelo menos uma técnica para solucionar o problema proposto;

\footnotetext{
Na realidade, o estudo e a resolução de um problema de um determinado tipo caminha sempre ao lado da constituição de ao menos um embrião de técnica, a partir do qual uma técnica mais desenvolvida poderá eventualmente emergir: o estudo de um problema particular, um tipo de espécime estudado, apareceria assim, não como um fim em si mesmo, senão como um meio para a constituição de uma técnica de resolução. Se trama assim uma dialética fundamental: estudar problemas é um meio que permite criar e por em marcha uma técnica relativa aos problemas do mesmo tipo, técnica que será a continuação ou meio para resolver de maneira quase rotineira os problemas deste tipo. (ibidem, p. 23). Tradução nossa.
}

Um exemplo simples, porém muito importante para a sobrevivência da raça humana, é a geração induzida de calor para acender uma fogueira, aquecer um alimento e/ou ferver a água. Apesar de, aparentemente, se tratar de tarefas banais e corriqueiras, nem sempre o foram e, dependendo das condições ambientais e dos instrumentos utilizados, ainda hoje podemos ter sérias dificuldades para realizá-las. Desse modo, no momento da exploração na OP didática, o indivíduo pode apresentar diferentes técnicas que lhe possibilitam resolver esse problema (ou tarefa), explorando inicialmente as possibilidades e estratégias oferecidas pelo material instrucional adotado (gravetos de diferentes tipos de madeira, pedaços pequenos de diferentes tipos de rocha, uma lente esférica convergente, produtos químicos, dentre outros). Nota-se que cada material demanda técnicas apropriadas para se resolver de maneira satisfatória a tarefa proposta ou problema em questão. As condições e procedimentos para acender uma fogueira usando uma lupa não são as mesmas quando se utiliza do atrito entre 
dois pedaços de madeira. Isso tudo pode vir à tona no momento da exploração e tende a caminhar para eleger as técnicas que mais tarefas permitem realizar e/ou melhor efetuá-las.

\section{Momento tecnológico-teórico}

De uma maneira geral, esse momento está entrelaçado com os demais momentos e vai se "atualizando" gradativamente, visto que o bloco tecnológico-teórico objetiva explicar e melhor compreender a(s) técnica(s) adotada(s) no momento da exploração (ainda em fase “embrionária”) que, por sua vez, pode(m) envolver múltiplas tarefas apresentadas no momento do primeiro encontro.

Curiosamente, os modelos mais "tradicionais" de ensino têm no momento tecnológico-teórico a primeira etapa do processo de estudo, partindo de uma teoria ou conceito para, em seguida, estudar e investigar vários tipos de problemas que surgem relativos a esse bloco tecnológico-teórico.

Por razões de economia didática global, às vezes as estratégias de direção de estudo tradicionais fazem, em geral, deste terceiro momento a primeira etapa do estudo, etapa até então comum ao estudo de vários tipos de problemas Ti - todos os que, entre os tipos de problemas a serem estudados, aparecem como relativos ao mesmo ambiente tecnológico-teórico $[\theta, \Theta]$. O estudo destes tipos de problemas apresenta-se então, classicamente, como uma série de aplicação do bloco tecnológico-teórico assim posto em marcha. (ibidem, p. 24). Tradução nossa.

No caso do ensino de Física, partir de uma teoria, expressão matemática ou conceito físico para depois apresentar os problemas e tarefas a serem investigados, é uma prática muito usual, praticamente uma regra geral. Em outras palavras, ensinam-se primeiramente soluções para problemas que ainda não foram apresentados ou formulados - A primeira lei de Newton diz que... A energia de cada fóton é dada por... A equação de Bernoulli relaciona... - e, assim, o momento tecnológico-teórico geralmente se faz presente primeiro para depois os problemas e tarefas a que estão atrelados surgirem. Procedendo desse modo, pode-se incorrer numa completa inversão do caminho aqui proposto para promover a contextualização, ou seja, iniciar-se-ia pela modelização dos saberes disciplinares para depois gerar os problemas.

\section{Momento de trabalho da técnica}

Marca o instante de trabalho efetivo da técnica e a retira da fase de exploração inicial (ou fase "embrionária") na qual se encontrava anteriormente. Esse momento busca vivenciar a 
técnica de tal modo a se obter seu máximo domínio e determinar sua precisão, validade e alcance (outras tarefas e problemas que são solucionados por uma mesma técnica). Pode provocar modificações e ampliações da técnica, ou o surgimento de uma nova técnica, ou ainda, despertar a necessidade de explicações tecnológicas e teóricas sobre a técnica utilizada.

O quarto momento é do trabalho da técnica, que deve de uma só vez melhorar a técnica tornando-a mais eficaz e mais confiável (o que exige geralmente retocar a tecnologia elaborada até então), e acrescentar a maestria que se tem dela: este momento de posta a prova a técnica supõe em particular um ou mais corpos de tarefas adequados tanto qualitativamente como quantitativamente. (ibidem, p. 24).

Determinar a velocidade de um corpo em movimento retilíneo uniforme (MRU) pode exigir inicialmente uma técnica relativamente simples. Fazendo uso de informações sobre o espaço percorrido $(\Delta \boldsymbol{x})$ e do tempo $(\Delta \boldsymbol{t})$ gasto para tal, é possível calcular essa velocidade $(\boldsymbol{v})$ por meio da expressão $\boldsymbol{v}=\Delta \boldsymbol{x} / \Delta \boldsymbol{t}$. Entretanto, se esse mesmo corpo estiver em movimento retilíneo uniformemente variado (MRUV), outras variáveis entram em jogo e a técnica adotada inicialmente não permitirá solucionar o problema de modo satisfatório. Nesse caso, é preciso obter informações sobre sua velocidade inicial $\left(\boldsymbol{v}_{\boldsymbol{i}}\right)$ e aceleração $(\boldsymbol{a})$, além de uma nova expressão $\boldsymbol{v}=\boldsymbol{v}_{\boldsymbol{i}}+\boldsymbol{a} . \Delta \boldsymbol{t}$. Por fim, se o problema consiste em determinar a posição final do corpo (em MRUV), outra técnica será necessária, porém, mais complexa e com poder de alcance que permite solucionar todos os outros problemas apresentados anteriormente. Nesse caso, será necessário adotar a expressão $\boldsymbol{v}=\boldsymbol{x}_{\boldsymbol{i}}+\boldsymbol{v}_{\boldsymbol{i}} \cdot \Delta \boldsymbol{t}+\boldsymbol{a} \cdot \Delta \boldsymbol{t}^{\mathbf{2}} / \mathbf{2}$, que se utiliza de informações sobre a posição inicial do corpo $\left(\boldsymbol{x}_{\boldsymbol{i}}\right)$ além das demais coletadas anteriormente. Vale ressaltar que a obtenção dos valores da velocidade, tempo, espaço e aceleração também compõem um quadro de possíveis tarefas a serem solucionadas e, consequentemente, de técnicas apropriadas para tal, por exemplo: para determinar o espaço percorrido por um corpo pode-se fazer uma medida direta utilizando a régua milímetrada, mas se a distância for maior que o instrumento permite mensurar, outras estratégias (técnicas) para efetuar essa medida deverão ser investigadas e adotadas.

\section{Momento da institucionalização}

É o momento quando a organização praxeológica (matemática, química, biológica, física, etc.) e de todos os seus componentes são oficializados de acordo com a instituição (escola, universidade, centro de pesquisa, sala de aula, grupo de estudos, corpo docente ou de pesquisadores, etc.) em que se desenvolve a atividade em questão. Passa-se de um estágio 
"informal” para um estágio "formal”, no qual os blocos prático-técnico e tecnológico-teórico são formalmente constituídos e enfatizados de maneira lógica e coesa, em acordo com a instituição que fomenta a OP em questão.

A noção de MRU (Movimento Retilíneo Uniforme), por exemplo, para existir, de fato, é necessário que o somatória das forças externas atuantes no sistema seja nulo. Isso é então destacado na OP Física, onde instituições como o professor, a escola, o pesquisador, dentre outros, são seu principal representante e "porta voz". Nesse exemplo, tal instituição pode enfatizar ainda a existência de movimento com resultante das forças externas nulas, o que, geralmente, é contrário ao senso comum e aos conhecimentos prévios que o aluno apresenta no momento da exploração e do primeiro encontro.

\section{Momento de avaliação}

Esse momento está atrelado ao da institucionalização, tendo em vista que se coloca em prova o domínio ou o entendimento que se tem de uma determinada OP elaborada no momento da institucionalização. Este momento pode ser vivido de maneira individual ou coletiva. De forma geral, trata-se de uma reflexão (por parte do aluno, professor ou qualquer indivíduo que passa por um processo de estudo, seja ele na escola ou fora dela e em qualquer momento da vida) sobre o uso da técnica e do conhecimento do bloco teórico que se tem ou se adquiriu por trás da técnica e tarefa realizada, formalizados na institucionalização.

Na prática, se chega a um momento em que se deve "fazer balanço", porque neste momento de reflexividade onde, qualquer que seja o critério e o juízo, se examina o que vale e o que se tem aprendido, este momento de verificação que, apesar das recordações da infância, não é em absoluto invenção da Escola, participa de fato da "respiração" própria de toda atividade humana. (ibidem, p. 25). Tradução nossa e grifo do autor.

Esse momento tem um caráter mais formador, no qual essa ou aquela fase do processo de estudo será revisto e repensado no processo educativo. Como bem aponta Chevallard,

Esta avaliação - a que concedem os usos escolares, em verdade, uma pequenina parte - é aqui formadora, não de uma pessoa, mas de uma praxeologia: a partir deste ponto de vista, participa a institucionalização. Como elemento reformador, permite relançar o estudo, suscitar a reposição de um determinado momento e, talvez, do conjunto do caminho didático. (ibidem, p. 25).

Assim, destacamos que "os momentos didáticos constituem uma ferramenta de análise das OP didáticas presentes em diversos meios" (ZANARDI, PEREIRA \& KNEUBIL, 2012, 
p. 13). Através dos momentos didáticos, buscamos identificar como estão presentes, ao longo do processo de estudo, os elementos praxeológicos identificados na OP didática. Em outras palavras, buscamos melhor compreender a dinâmica do processo de contextualização no ensino de Física, fazendo uso de recursos diferenciados. Os métodos de análise empregados para esse estudo e os dados coletados são apresentados no capítulo seguinte, capítulo 4. 


\title{
Capítulo 4 - MÉTOdos de ANÁlise e DAdOS.
}

\begin{abstract}
"Antes de qualquer tentativa de discussão de técnicas, de materiais, de métodos para uma aula dinâmica assim, é preciso, indispensável mesmo, que o professor se ache "repousado" no saber de que a pedra fundamental é a curiosidade do ser humano. E ela que me faz perguntar, conhecer, atuar, mais perguntar, reconhecer."
\end{abstract}

Paulo Freire $^{19}$

No capítulo anterior, apresentamos e discutimos a Teoria Antropológica do Didático (TAD) e mostramos como ela pode ser adotada para melhor compreender a contextualização em termos de tarefas, técnicas, tecnologias e teorias. Nesse cenário, a OP de referência é formada ou faz parte de instituições que, por sua vez, possuem tarefas que são efetivadas por determinadas técnicas, compreendidas por tecnologias e teorias. Alguns desses elementos praxeológicos surgem na OP didática de acordo com a intenção didática da instituição (professor, escola, pesquisador, currículo, etc.). Assim, em um processo de estudo, o indivíduo deve gradativamente mudar sua relação com o objeto daquela prática social de referência.

${ }^{19}$ In. Pedagogia da Autonomia. $36^{\text {a }}$ edição, São Paulo: Editora Paz e Terra, 2007, p. 86. 
Nessa perspectiva, concentraremos inicialmente nossos esforços na análise do aspecto estrutural, ou seja, das organizações praxeológicas didática e de referência, investigando se há e quais são os "elementos" que norteiam o desenvolvimento da problematização e modelização? Como esses elementos promovem (ou não) a contextualização?

Quanto ao aspecto funcional (os momentos didáticos), nos questionamos se, no decorrer do processo de implementação das atividades de ensino-aprendizagem, haverá elementos da OP didática que precisam ser reformulados? Há algum momento de estudo que se estende para além do esperado e diverge da intenção didática do professor, prejudicando a sequência didática? Os recursos oferecidos pela robótica educacional favorecem algum dos momentos de estudo de maneira positiva na promoção do processo de contextualização almejado na OP didática? Em caso positivo, como e por quê? São essas as questões que nos propomos a investigar tomando como instrumento de análise o aspecto funcional da TAD.

Contudo, são necessárias estratégias metodológicas variadas de pesquisa, uma vez que a análise envolve duas dimensões. Uma é em relação às OPs, em que será preciso identificar, sintetizar e expor os principais tipos de tarefas, técnicas, tecnologias e teorias das OPs didática e de referência selecionadas para investigação. A OP didática configura-se como o contexto da pesquisa desta tese. É por meio dela que os processos e mecanismos da contextualização surgem e são analisados. A outra dimensão refere-se aos momentos didáticos, que neste caso fomentam a análise de atividades realizadas por alunos no ambiente escolar. Essas duas dimensões e suas respectivas estratégias metodológicas são tratadas na sequência.

\section{1 - Delimitação das Organizações Praxeológicas}

A OP didática será analisada a partir de atividades de robótica educacional, contidas no projeto desenvolvido em 2008 pelo NUPIC ${ }^{20}$ (Núcleo de Pesquisas em Inovação Curricular) em parceria com a Lego Education do Brasil ${ }^{21}$. Como mencionamos brevemente na apresentação desta tese, esse projeto reuniu profissionais com o intuito de elaborar e escrever atividades de robótica a serem utilizadas em aulas de Física do ensino médio, fazendo uso de kits da Lego Mindstorms $N X T^{22}$.

\footnotetext{
${ }^{20} \mathrm{http}: / /$ www.nupic.fe.usp.br/ Acesso em 02 de Fevereiro de 2013.

${ }^{21} \mathrm{http}: / /$ www.legozoom.com/ Acesso em 03 de Julho de 2014.

${ }_{22}^{2}$ Os kits de robótica da Lego e os fascículos didáticos podem ser adquiridos pelas escolas públicas por meio de licitação ou contrato com a Lego Education do Brasil. 
As atividades foram construídas considerando a utilização de um kit de montagem para cada grupo de quatro alunos, acompanhado de um fascículo didático para cada estudante. Também foram elaboradas concebendo-se uma situação problema por meio da criação e desenvolvimento de montagens de robôs e sensores para coleta de dados. A partir daí, as montagens eram aprovadas e certificadas pela equipe da Lego para, posteriormente, serem escritos os manuais do aluno e também do professor.

Conforme discutimos no início desta tese, as propostas didáticas para elaboração dos fascículos tiveram como principal base metodológica os três momentos pedagógicos que envolvem a resolução de um problema, a saber: i) problematização inicial; ii) organização do conhecimento; iii) aplicação do conhecimento (ANGOTTI \& DELIZOICOV, 2002; DELIZOICOV, 1991, 2005). Desse modo, houve a preocupação de fazer com que os conceitos da Física fossem utilizados de maneira clara para se resolver um problema proposto aos alunos a partir de contextos extraídos de situações cotidianas ou presentes na sociedade em geral. Tais situações se caracterizam como atividades humanas presentes em diversos "cenários" e compõem, assim, as OPs de referência que iremos analisar, contrastadas com suas respectivas OPs didática (atividades dos fascículos). Cada atividade apresenta então uma situação-problema e uma possível solução, de tal modo que seja possível surgir o confronto entre os entendimentos prévios de que o estudante dispõe e os novos conhecimentos trazidos pelo professor. O fechamento da atividade ocorre quando os conhecimentos adquiridos ganham sentido e amplitude ao serem aplicados a novas situações.

Para o primeiro e segundo ano do ensino médio, foram desenvolvidos oito fascículos, um por bimestre (totalizando em 32 atividades). Cada fascículo envolve um tema central com conteúdos específicos a serem abordados (Tabela 3 e Tabela 4) e possui uma estrutura prédeterminada em sessões, a saber: Abertura, que introduz a atividade, geralmente por meio de uma história em quadrinhos (HQ) ou um breve texto histórico e ilustrações; Introduzindo o Problema, sessão na qual se apresenta um problema, envolvendo a situação da abertura, que deve ser investigado e resolvido pelo aluno; Compreendendo o Problema, que objetiva detalhar o problema, expondo os conhecimentos envolvidos e apresentando novas questões para orientá-los no estudo; Concebendo um Plano, sessão na qual se propõe maiores discussões a respeito das grandezas que devem ser determinadas, métodos de medidas mais adequados e/ou estratégias de trabalho e ação para melhor investigar e resolver o problema apresentado; Organização e Montagem, estritamente relacionada à montagem correspondente à atividade, às instruções de programação e/ou à material extra necessário; Testes e/ou 
Medidas e Cálculos, apresentam questões, testes e cálculos que orientam os estudantes na resolução da atividade; Extensão e Situação-Problema, são atividades opcionais com intuito de permitir aprofundar o conhecimento a respeito da questão inicial e apresentar novos desafios relacionados à proposta central, aplicando e explorando o conhecimento adquirido em novas áreas e realizando novas montagens.

Tabela 3 - Grade de conteúdos e atividades. Fascículos para o $1^{\circ}$ ano do Ensino Médio.

\begin{tabular}{|c|c|c|c|c|}
\hline Fascículo & $\begin{array}{l}\text { Período } \\
\text { Letivo }\end{array}$ & $\begin{array}{l}\text { Conteúdos } \\
\text { abordados }\end{array}$ & Atividade & Áreas Contempladas \\
\hline \multirow{4}{*}{$\begin{array}{l}\infty \\
0 \\
0 \\
0 \\
0 \\
0 \\
0 \\
0 \\
0 \\
0\end{array}$} & \multirow{4}{*}{ 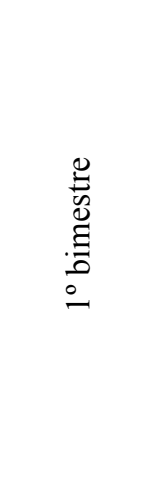 } & \multirow{4}{*}{$\begin{array}{l}\text { Medidas de tempo; } \\
\text { movimento retilíneo } \\
\text { uniforme; movimento } \\
\text { circular uniforme; } \\
\text { movimento } \\
\text { uniformemente } \\
\text { variado; queda livre, } \\
\text { lançamento } \\
\text { Horizontal; } \\
\text { lançamento oblíquo. }\end{array}$} & $\begin{array}{l}\text { Movimentos e } \\
\text { Medidas do } \\
\text { Tempo }\end{array}$ & $\begin{array}{l}\text { Física, Matemática, História, } \\
\text { Geografia, Filosofia e Tecnologia }\end{array}$ \\
\hline & & & $\begin{array}{l}\text { Luz! Câmera! } \\
\text { Ação! }\end{array}$ & $\begin{array}{c}\text { Física, Matemática e Educação } \\
\text { Artística }\end{array}$ \\
\hline & & & $\begin{array}{l}\text { Cesta! Três } \\
\text { Pontos! }\end{array}$ & $\begin{array}{c}\text { Física, Matemática e Educação } \\
\text { Física }\end{array}$ \\
\hline & & & $\begin{array}{l}\text { A face oculta da } \\
\text { Lua }\end{array}$ & Física, Matemática e Geografia \\
\hline \multirow{4}{*}{ 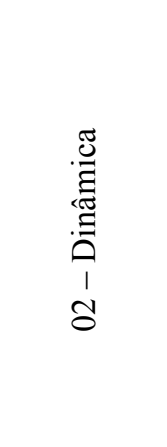 } & \multirow{4}{*}{$\begin{array}{l}\stackrel{0}{\Xi} \\
\stackrel{0}{\Xi} \\
\stackrel{\Xi}{0} \\
\stackrel{2}{2}\end{array}$} & \multirow{4}{*}{$\begin{array}{c}\text { Sistemas } \\
\text { Heliocêntrico e } \\
\text { Geocêntrico, } \\
\text { referencial, três leis } \\
\text { de Newton, plano } \\
\text { inclinado, força de } \\
\text { atrito e força } \\
\text { centrípeta. }\end{array}$} & $\begin{array}{c}\text { Galileu e o } \\
\text { movimento da } \\
\text { Terra }\end{array}$ & Física, Matemática e História \\
\hline & & & Pisa no freio! & $\begin{array}{c}\text { Física, Matemática, Psicologia e } \\
\text { Tecnologia }\end{array}$ \\
\hline & & & O resgate & Física e Matemática \\
\hline & & & $\begin{array}{l}\text { Atrito entre } \\
\text { superfícies }\end{array}$ & Física, Matemática e Tecnologia \\
\hline \multirow{4}{*}{ 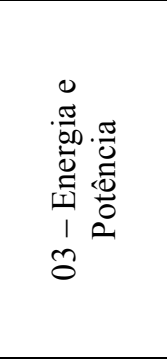 } & \multirow{4}{*}{ 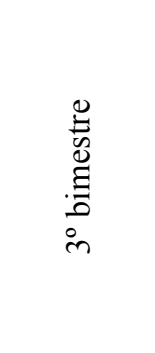 } & \multirow{4}{*}{$\begin{array}{l}\text { Energia potencial, } \\
\text { energia cinética, } \\
\text { energia mecânica, } \\
\text { pressão, trabalho, } \\
\text { quantidade de } \\
\text { movimento linear e } \\
\text { colisões. }\end{array}$} & Investigando solos & $\begin{array}{l}\text { Física, Matemática, Geografia, } \\
\text { Educação Artística e Tecnologia }\end{array}$ \\
\hline & & & $\begin{array}{l}\text { Quantidade de } \\
\text { movimento }\end{array}$ & Física, Matemática e Tecnologia \\
\hline & & & Colisões & Física, Matemática e Tecnologia \\
\hline & & & Clube do Canhão & Física, Matemática e Tecnologia \\
\hline \multirow{4}{*}{ 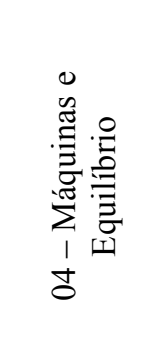 } & \multirow{4}{*}{ 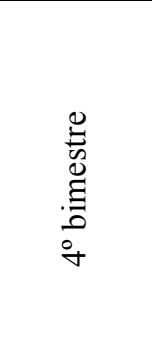 } & \multirow{4}{*}{$\begin{array}{l}\text { Torque, equilíbrio } \\
\text { estático, equilíbrio } \\
\text { dinâmico, centro de } \\
\text { massa e máquinas } \\
\text { simples. }\end{array}$} & Elevador & $\begin{array}{c}\text { Física, Matemática, História e } \\
\text { Tecnologia }\end{array}$ \\
\hline & & & Carro com marcha & Física, Matemática e Tecnologia \\
\hline & & & Empilhadeira & Física, Matemática e Tecnologia \\
\hline & & & Carga pesada & $\begin{array}{c}\text { Física, Matemática, História e } \\
\text { Tecnologia }\end{array}$ \\
\hline
\end{tabular}

Fonte: PIETROCOLA et al, 2010, p. 18. 
Tabela 4 - Grade de conteúdos e atividades. Fascículos para o $2^{\circ}$ ano do Ensino Médio.

\begin{tabular}{|c|c|c|c|c|}
\hline Fascículo & $\begin{array}{c}\text { Período } \\
\text { Letivo }\end{array}$ & Conteúdos abordados & Atividade & $\begin{array}{c}\text { Áreas } \\
\text { Contempladas }\end{array}$ \\
\hline \multirow{4}{*}{ 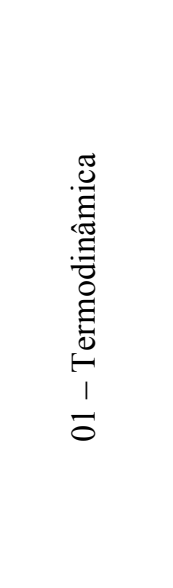 } & \multirow{4}{*}{ 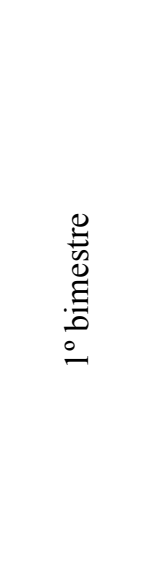 } & \multirow{4}{*}{$\begin{array}{l}\text { Princípio de conservação de energia, } \\
\text { calor, temperatura, equilíbrio térmico, } \\
\text { trocas de calor, calor específico, teoria } \\
\text { cinética dos gases, estados da matéria, } \\
\text { calor e ambiente, efeito estufa. }\end{array}$} & $\begin{array}{l}\text { O } \\
\text { Equivalente } \\
\text { Mecânico do } \\
\text { Calor }\end{array}$ & $\begin{array}{l}\text { Física, Matemática, } \\
\text { História, Geografia, } \\
\text { Filosofia e } \\
\text { Tecnologia }\end{array}$ \\
\hline & & & $\begin{array}{l}\text { O Modelo } \\
\text { Cinético } \\
\text { Molecular da } \\
\text { Matéria }\end{array}$ & $\begin{array}{l}\text { Física, Matemática e } \\
\text { Educação Artística }\end{array}$ \\
\hline & & & $\begin{array}{l}\text { Conforto } \\
\text { Térmico }\end{array}$ & $\begin{array}{l}\text { Física, Matemática e } \\
\text { Educação Física }\end{array}$ \\
\hline & & & $\begin{array}{l}\text { Estufas } \\
\text { Agrícolas }\end{array}$ & $\begin{array}{c}\text { Física, Matemática e } \\
\text { Geografia }\end{array}$ \\
\hline \multirow{4}{*}{ 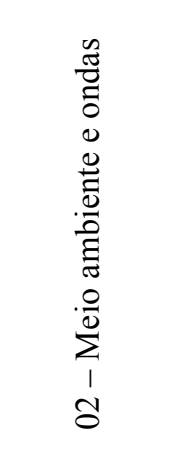 } & \multirow{4}{*}{ 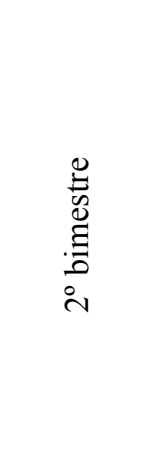 } & \multirow{4}{*}{$\begin{array}{l}\text { Ondas mecânicas, velocidade de } \\
\text { propagação, frequência, comprimento de } \\
\text { onda, amplitude, pulso e reflexão de uma } \\
\text { onda, espectro sonoro e função de onda. }\end{array}$} & Sonar & $\begin{array}{c}\text { Física, Matemática e } \\
\text { História }\end{array}$ \\
\hline & & & Sismógrafo & $\begin{array}{c}\text { Física, Matemática, } \\
\text { Psicologia e } \\
\text { Tecnologia }\end{array}$ \\
\hline & & & $\begin{array}{l}\text { Gerador de } \\
\text { Ondas }\end{array}$ & Física e Matemática \\
\hline & & & Gramofone & $\begin{array}{c}\text { Física, Matemática e } \\
\text { Tecnologia }\end{array}$ \\
\hline \multirow{4}{*}{ 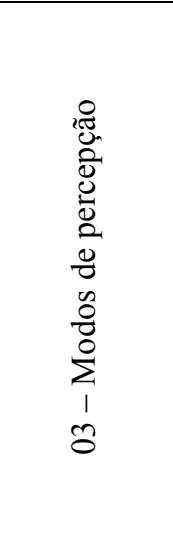 } & \multirow{4}{*}{ 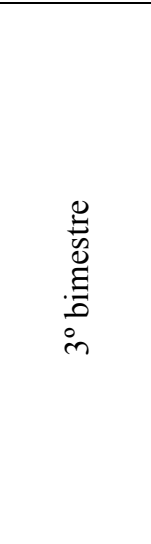 } & \multirow{4}{*}{$\begin{array}{l}\text { Corpos luminosos e iluminados, visão das } \\
\text { cores, espelhos planos, tipos de lente, } \\
\text { construção gráfica de imagens, equação de } \\
\text { conjugação das lentes esféricas, cálculo da } \\
\text { vergência de uma lente, fisiologia do } \\
\text { bulbo ocular, associação de lentes, } \\
\text { instrumentos ópticos (microscópios } \\
\text { simples e compostos), equação do } \\
\text { aumento do microscópio composto, } \\
\text { instrumentos ópticos de projeção (câmara } \\
\text { escura de orifício, máquina fotográfica, } \\
\text { projetor de slides). }\end{array}$} & $\begin{array}{l}\text { Conforto } \\
\text { Luminoso }\end{array}$ & $\begin{array}{c}\text { Física, Matemática, } \\
\text { Geografia, Educação } \\
\text { Artística e } \\
\text { Tecnologia }\end{array}$ \\
\hline & & & Cinema & $\begin{array}{c}\text { Física, Matemática e } \\
\text { Tecnologia }\end{array}$ \\
\hline & & & $\begin{array}{l}\text { Fotógrafo } \\
\text { Lambe-lambe }\end{array}$ & $\begin{array}{c}\text { Física, Matemática e } \\
\text { Tecnologia }\end{array}$ \\
\hline & & & Microscópio & $\begin{array}{c}\text { Física, Matemática e } \\
\text { Tecnologia }\end{array}$ \\
\hline \multirow{4}{*}{ 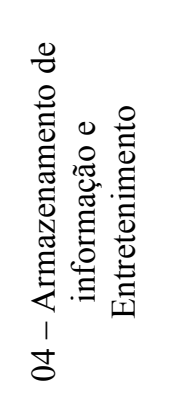 } & \multirow{4}{*}{ 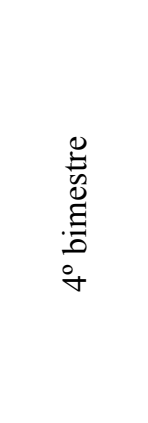 } & \multirow{4}{*}{$\begin{array}{l}\text { Modos de vibração de uma corda, } \\
\text { frequências naturais de vibração, sons } \\
\text { graves e agudos, instrumentos de corda e } \\
\text { qualidades fisiológicas do som } \\
\text { (harmônicos e timbre), oscilações } \\
\text { forçadas, ressonância, armazenamento de } \\
\text { informações digitais. }\end{array}$} & $\begin{array}{l}\text { Um Toque } \\
\text { Musical }\end{array}$ & $\begin{array}{l}\text { Física, Matemática, } \\
\text { História e Tecnologia }\end{array}$ \\
\hline & & & Ressonância & $\begin{array}{c}\text { Física, Matemática e } \\
\text { Tecnologia }\end{array}$ \\
\hline & & & $\begin{array}{l}\text { Código de } \\
\text { Barras }\end{array}$ & $\begin{array}{c}\text { Física, Matemática e } \\
\text { Tecnologia }\end{array}$ \\
\hline & & & $\begin{array}{l}\text { Isolamento } \\
\text { Acústico }\end{array}$ & $\begin{array}{l}\text { Física, Matemática, } \\
\text { História e Tecnologia }\end{array}$ \\
\hline
\end{tabular}

Fonte: PIETROCOLA et al, 2010b, p. 18. 
Alguns dos referidos fascículos já foram explorados de forma preliminar em pesquisas anteriores, especialmente os temas "Energia e Potência" e "Máquinas e Equilíbrio" (ROUXINOL et al, 2011; SCHIVANI \& PIETROCOLA, 2012, 2013; SCHIVANI, BROCKINGTON \& PIETROCOLA, 2013). Continuando essa investigação, optamos por um total de quatro atividades de fascículos do primeiro e segundo ano do ensino médio que corresponderão às Organizações Praxeológicas Didática a serem analisadas, a saber: Empilhadeira; Colisões; Sismógrafo; Código de barras. O contexto, extraído de situações cotidianas ou presentes na sociedade em geral, explorado por cada uma dessas atividades formam às Organizações Praxeológicas de Referência.

\subsection{1 - Atividade "Empilhadeira"}

A atividade "Empilhadeira" faz parte do quarto fascículo, Máquinas e Equilíbrio (Figura 10), para o primeiro ano do ensino médio (PIETROCOLA et al, 2010d). Essa atividade envolve estudos sobre torque e braço de alavanca em uma situação de transporte de cargas por uma empilhadeira elétrica. É uma atividade de caráter introdutório no estudo do equilíbrio dos corpos rígidos e tem como pré-requisito o conceito de centro de massa, que deve ser abordado pelo professor antes de se iniciar a atividade.

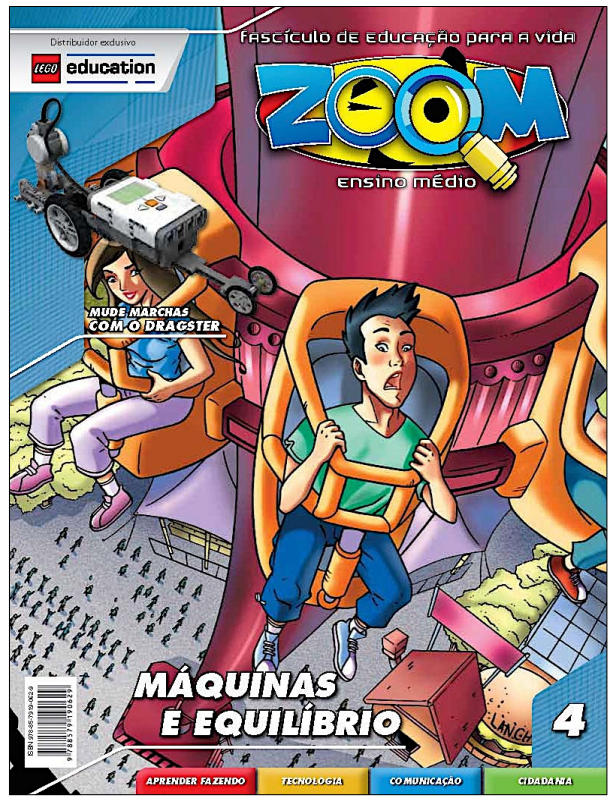

Figura 10 - Capa do fascículo Máquinas e Equilíbrio.

Por meio de uma história de quadrinhos (HQ), o fascículo ilustra inicialmente uma situação hipotética em que o condutor da empilhadeira está prestes e sofrer um acidente 
(Figura 11). Na sequência, discutem-se os cuidados e desafios para conduzir uma empilhadeira, além da capacidade máxima de carga a ser transportada e condições necessárias para tal.

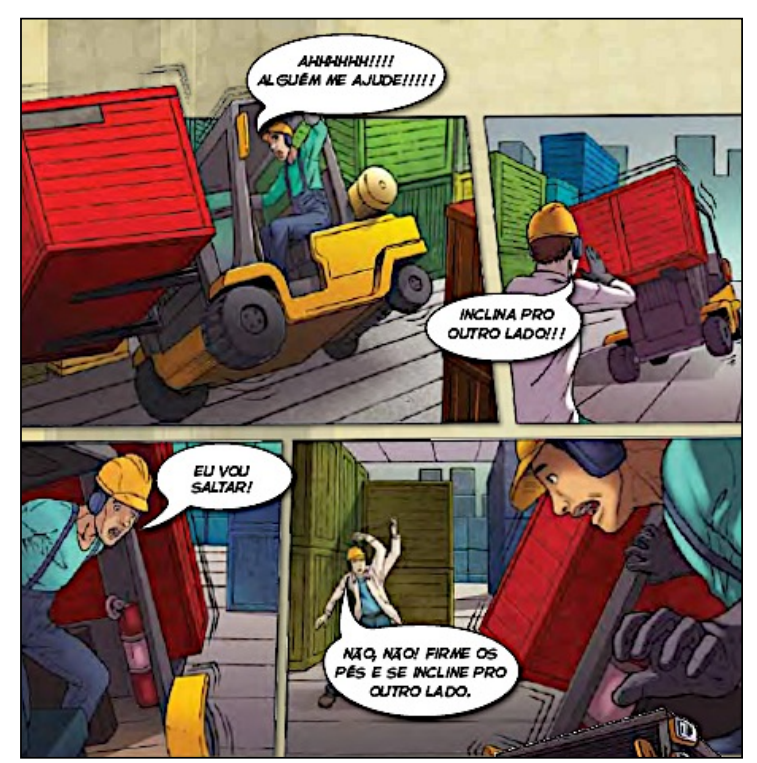

Figura 11 - HQ ilustrando uma situação hipotética de acidente com empilhadeira.

De acordo com extratos do fascículo, podemos determinar que a OP de referência dessa atividade é o transporte de cargas via empilhadeiras elétricas de pequeno porte, a saber:

As empilhadeiras que costumamos ver em armazéns, portos, aeroportos etc., podem até parecer carrinhos de brinquedo, fáceis de conduzir. No entanto, dirigir empilhadeiras exige treinamento e habilitação específica para cada uma de suas modalidades. O princípio de funcionamento de uma empilhadeira envolve conhecimentos físicos sobre força, peso, centro de massa, equilíbrio estático e estável e torque. Mas não basta entender Física para ser habilitado para conduzir empilhadeiras. Então, como analisar a carga máxima suportada por uma empilhadeira? Como determinar o contentor adequado para cada carga? (PIETROCOLA et al, 2010d, p. 23).

Por meio desses questionamentos, o aluno é apresentado ao princípio da alavanca (ou princípio da gangorra), sendo indagado também sobre como a carga máxima suportada pela empilhadeira está diretamente relacionada a esse princípio. A investigação inicia-se com o desenvolvimento de um diagrama de forças da empilhadeira e sua carga.

Antes de desenvolver a montagem para investigar o problema central (determinar a carga máxima para uma empilhadeira e o tamanho adequado do contêiner para o transporte), é solicitado ao grupo que discuta algumas questões de modo a melhor desenvolver um "plano de estudo", tais como: A empilhadeira tem obrigatoriamente um contrapeso? Se funciona utilizando o princípio da gangorra, onde se encontra o centro de rotação da empilhadeira 
(ou apoio da gangorra)? Além do peso da carga, que outro(s) fator(es) influencia(m) na capacidade da empilhadeira?

Para simular a empilhadeira, o fascículo propõe uma montagem específica orientada por um passo-a-passo e utilizando o kit de robótica Lego Mindstorms NXT. Nessa montagem, conforme ilustra a Figura 12, o próprio NXT (tijolo programável) e os motores servem para compor o contrapeso, já as rodas dianteiras perfazem o fulcro (ponto de apoio). A carga (nesse caso, bolinhas de gude) é posicionada a uma determinada distância do fulcro e é deslocada verticalmente, por uma torre de elevação composta de polias, cabos e motor, e horizontalmente, impulsionada pelos motores que movem a empilhadeira como um todo. Os contentores, os quais recebem a carga, são feitos de papel e seguem moldes de tamanhos diferentes (tipo P, M e G) para possibilitar estudos sobre variação do centro de massa da carga.

Após a montagem da empilhadeira, são recomendados alguns testes de transporte de bolinhas de gude e de distribuição da carga usando como referência a capacidade máxima de carga do contentor tipo P. Fazendo uso de uma balança digital, verifica-se também a massa total de bolinhas suportada por cada tipo de contentor.

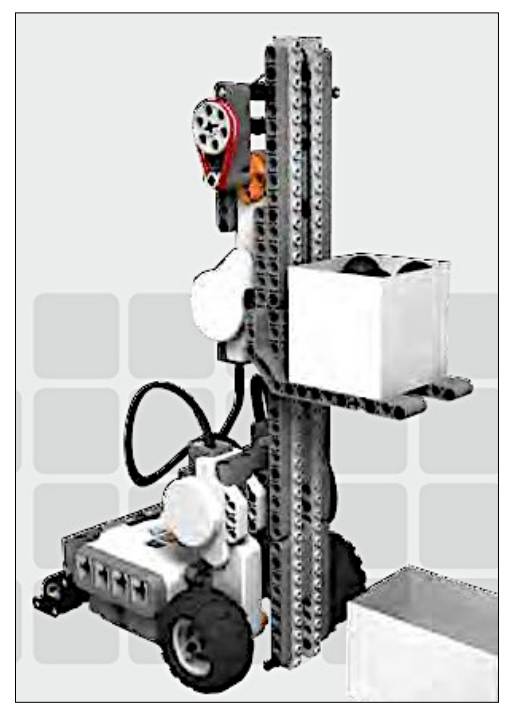

Figura 12 - Transporte de cargas por elevação vertical e horizontal (Atividade "Empilhadeiras").

Por fim, a empilhadeira é utilizada para se verificar como se dá o transporte de carga em relação à distribuição de massa e seu posicionamento. Para isso, é solicitado o desenvolvimento de um gráfico que apresente a relação entre a capacidade de carga 
transportada (de forma segura e em equilíbrio estável) com a distância do seu centro de massa ao fulcro da empilhadeira (centro das rodas dianteiras). Como atividade opcional ou de extensão, são sugeridas modificações no tamanho do garfo da empilhadeira para se verificar as implicações que essa alteração acarreta na capacidade de transporte das cargas.

\subsection{2 - Atividade "Colisões"}

A atividade "Colisões" corresponde ao módulo Energia e Potência e compõe o terceiro fascículo para o primeiro ano do Ensino Médio (Figura 13). Essa atividade discute inicialmente as colisões sofridas por veículos que participam de uma competição de carros demolidores, também conhecida como campeonato de "Schok Car"23.

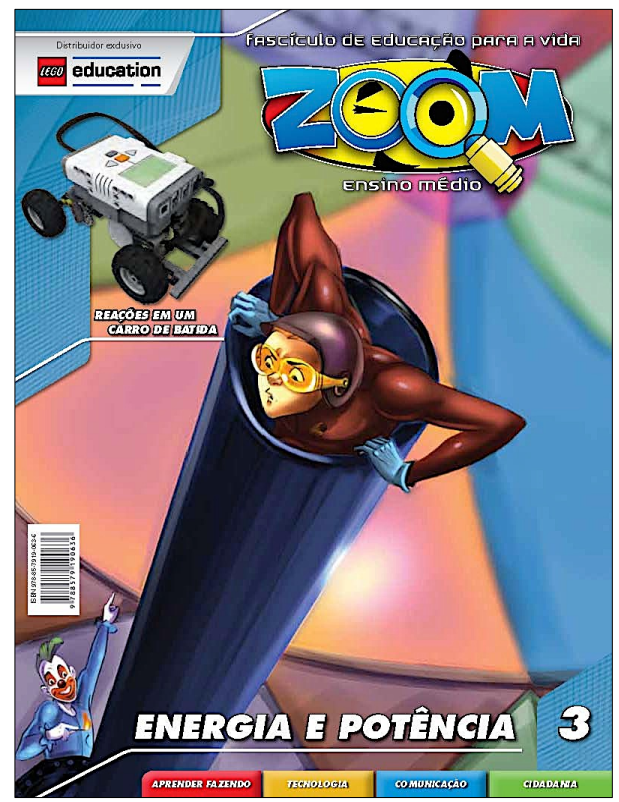

Figura 13 - Capa do fascículo Energia e Potência.

Podemos determinar que a OP de referência dessa atividade remete a um campeonato em que há colisões entre veículos de diferentes massas e velocidades, além dos diversos tipos de batida (frontal, traseira, etc.), a saber:

Vence uma disputa de carros demolidores o piloto que permanecer por mais tempo com o carro em movimento. Mas não vale se esconder! Apesar de parecer uma grande bagunça, não se trata de um vale-tudo. Os carros de demolição participam de um evento esportivo que conta com um rígido regulamento. Os carros não podem permanecer por mais de três minutos sem bater em outro. Se isso acontecer, o carro é desclassificado. Há duas categorias de veículos que podem participar: veículos leves - como

\footnotetext{
${ }^{23}$ Exemplo de campeonato de Schok Car: http://www.youtube.com/watch?v=Od6xKbvYIcM Acesso em 02 de julho de 2014.
} 
Chevette, Gol e Caravan - e veículos pesados - como Dodge e Maverick. O objetivo é destruir o motor do carro, uma vez que a finalidade é interromper o seu funcionamento por completo. Pilotos experientes dizem que as batidas mais eficientes são feitas em marcha ré e direcionadas na traseira do oponente, de preferência quando este estiver parado ou em baixa velocidade. (PIETROCOLA et al, 2010c, pp. 22).

Questões sobre a importância da velocidade e da massa dos veículos na transmissão de movimento a outros corpos em uma situação de colisão também são apresentadas na OP didática. Com isso, a atividade propõe o estudo da transferência do momento linear por meio da colisão entre veículos "robô". A colisão entre os veículos desenvolvida na atividade didática é apenas frontal com variação de massa $(\mathrm{m})$ em três situações distintas, a saber: $m_{\text {Carro } A}=m_{\text {Carro } B} ; m_{\text {Carro } A}<m_{\text {Carro } B}$ e $m_{\text {Carro } A}>m_{\text {Carro } B}$. Para gerar essa situação de colisão e coletar dados sobre a velocidade dos veículos antes e após cada colisão, é proposto que os veículos se desloquem sobre uma faixa com listas brancas e pretas (Figura 14)

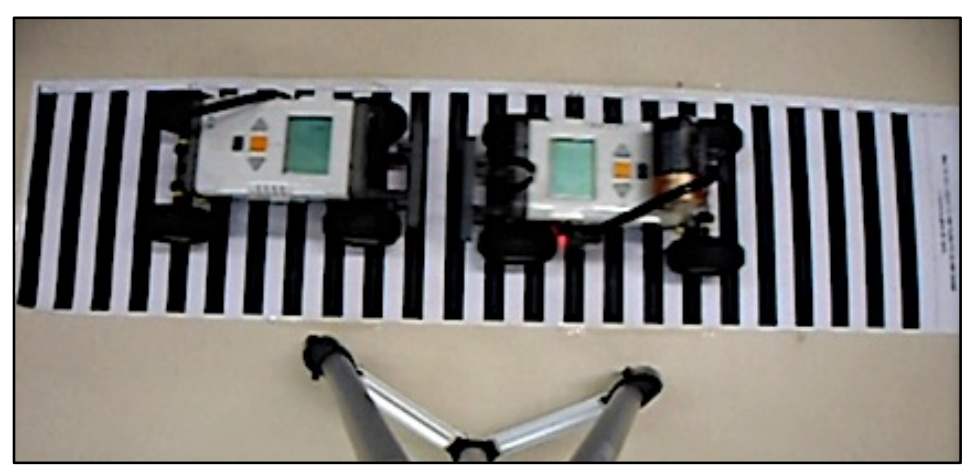

Figura 14 - Choque frontal entre veículos "robô" (Atividade "Colisões").

Uma vez sabendo a largura das listas, utiliza-se um sensor de luz acoplado a estrutura dos carros para mensurar o tempo de deslocamento entre as listas, antes e depois do choque frontal, possibilitando, assim, determinar suas velocidades. Em seguida, sabendo a velocidade de cada veículo e sua massa, é solicitado calcular a quantidade de movimento linear antes e depois de cada colisão para cada situação simulada, bem como o valor teórico da velocidade dos veículos para o caso em que houvesse conservação do momento linear.

Cada equipe de alunos é responsável pela construção de um carro, que será utilizado na colisão com o carro de outro grupo, ou seja, o embate será entre carros de duas equipes. Um dos veículos permanecerá em repouso e o outro causará a batida. Por sorteio, é decidido qual equipe vai ficar com o veículo robô que provocará o choque.

A programação exigida é relativamente complexa e diferente para cada veículo robô. Para o carro que fica em repouso antes da batida, é registrado o tempo, em milésimos de 
segundo, que leva para passar por três faixas após receber o choque. Para o carro que provoca a batida, é preciso fazer com que ele saia do repouso, desenvolva certa velocidade e, ao passar pela primeira faixa da lista, destrave as rodas (desligando os motores e desconectando o sistema de engrenagens) de tal modo que no momento da colisão esteja em movimento retilíneo uniforme, ou seja, com velocidade constante. Em seguida, imediatamente após destravar as rodas, deve-se registrar o tempo que o carro que provocou a batida leva para passar por sete faixas. Todo esse processo é comandado pela programação que se utiliza de informações coletadas por um sensor de luz, o qual também é programado para registrar o tempo que decorre da passagem do veículo entre cada lista.

Por fim, como atividade opcional ou de extensão, são discutidas questões sobre energia cinética $\left(E_{c}\right)$ e calcula-se qual foi a variação da energia cinética $\left(\Delta E_{c}\right)$, ou seja, se houve perdas e de quanto foi. Em função disso, os tipos de colisão são classificados em elástica (em que não há perdas de energia cinética) e inelástica (a variação da energia cinética é diferente de zero). É proposto ainda o estudo e desenvolvimento de para-choques com materiais alternativos de tal modo que o impacto da colisão entre os veículos robô seja amenizado.

\subsection{3 - Atividade "Sismógrafo"}

Compondo o segundo fascículo para o segundo ano do ensino médio, essa é a segunda atividade do módulo "Meio Ambiente e Ondas" (Figura 15).

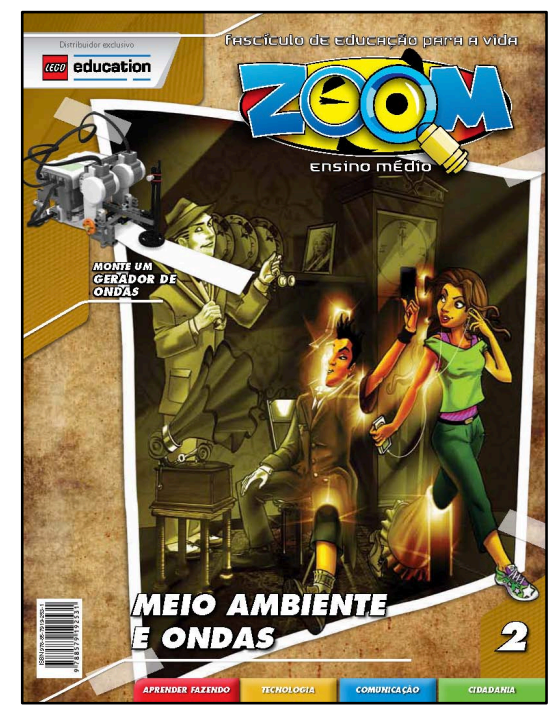

Figura 15 - Capa do fascículo Meio Ambiente e Ondas. 
Consiste em uma atividade de aprofundamento no estudo das ondas mecânicas a partir do funcionamento básico do sismógrafo e da elaboração de um sismograma. Inicia-se apresentando uma notícia de jornal sobre terremotos de pequena escala percebidos por moradores de algumas cidades brasileiras e registrados por sismógrafos. Na sequência, ao identificar o problema, são levantadas questões sobre o que são ondas sísmicas, os tipos e as formas de propagação, bem como sobre a importância da interpretação de sismogramas (registro gráfico do movimento do solo em determinada região). A OP de referência remete ao uso de sismógrafos para detectar e registrar abalos sísmicos de diferentes intensidades e amplitudes.

A tarefa central dessa atividade consiste em analisar, interpretar e avaliar a amplitude, a duração, a intensidade e os efeitos provocados por sismos registrados em um sismograma. Para isso, é proposto a simulação de um abalo sísmico, obtido através da montagem indicada no fascículo (Figura 16), e a programação é fornecida pelo professor, previamente inserida no NXT. Essa montagem apresenta um pêndulo que tem seu movimento de oscilação monitorado por um sensor óptico. As informações registradas pelo sensor são transmitidas para o tijolo programável (NXT) que as decodifica e gera o sismograma.

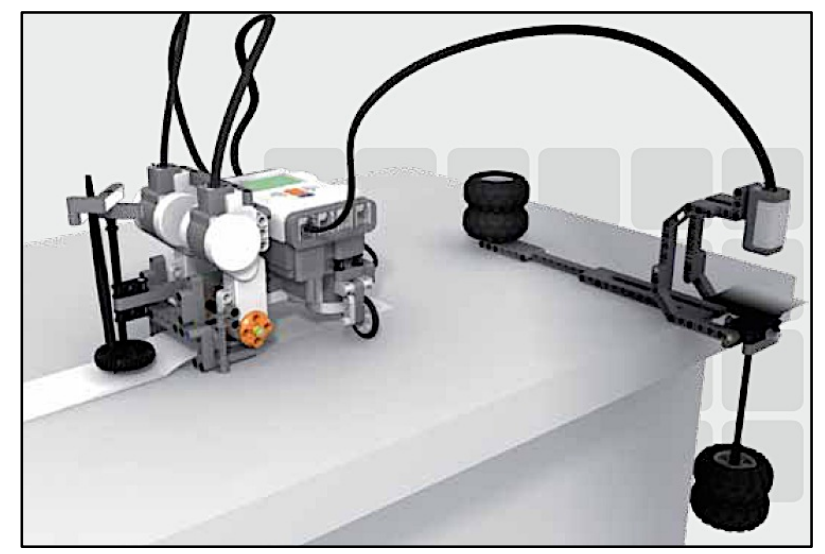

Figura 16 - Montagem proposta para simular e registrar uma onda sísmica.

Ainda na fase de organização e montagem, é solicitado ao grupo que discuta e responda algumas questões, a saber: Como determinar a amplitude média da oscilação no tempo considerado? Como determinar a velocidade da oscilação no sismograma? Como estimar a intensidade da vibração?

Os grupos serão responsáveis pela produção dos tremores a serem detectados pelo sismógrafo. Para produzir as oscilações, o pendulo (ou sensor) que compõe a montagem do sismógrafo na OP didática deve ser posto sobre uma caixa ou livro que será deslocado em 
função do "padrão de oscilações" que se pretende gerar (em um intervalo de tempo total de um minuto). Cada grupo de alunos deve elaborar um "plano de terremoto", no qual um padrão de oscilações deverá ser gerado (vibrando a base que apoia o sensor do sismógrafo) e registrado pelo sismógrafo. Esse registro é impresso numa bobina de papel, produzindo, desse modo, um sismograma, que deverá ser interpretado por outro grupo que não poderá conhecer o "plano de terremoto" planejado pela equipe.

O sismograma deve ser analisado pelos alunos para classificar a intensidade da oscilação em fraca, média, forte ou nula (não houve oscilação) de acordo com o intervalo de tempo (mínimo 5 e máximo de 15 segundos de duração). Em seguida, partindo do mesmo sismograma, deve-se analisar a amplitude média das oscilações verificadas em cada intervalo de tempo, descobrir a duração (intervalo de tempo aproximado) da intensidade dos diferentes tremores, a frequência e o período das oscilações.

A atividade apresenta ainda uma escala, inspirada na "Escala Mercalli" (uma escala qualitativa usada para determinar a intensidade de um terremoto em função dos efeitos físicos causados), a partir da qual os alunos devem verificar a frequência e os efeitos produzidos pelas oscilações detectadas pelo sismógrafo.

Por fim, como prática opcional ou de extensão, é discutida a "Escala Richter", uma escala logarítmica utilizada para medir a magnitude de abalos sísmicos. Nessa etapa, uma das tarefas propostas consiste em determinar a magnitude do suposto terremoto a partir da escolha da amplitude de dois intervalos de oscilação obtidos pelo sismograma, bem como calcular a energia liberada.

\subsection{4 - Atividade "Código de barras"}

Essa atividade explora um assunto pouco abordado em sala de aula: conceitos básicos sobre armazenamento de informações digitais por código de barras, sistemas binários e estados lógicos. Trata-se da terceira atividade do quarto fascículo (Figura 17a) sobre “Armazenamento de Informação e Entretenimento".

Uma HQ (Figura 17b) abre a atividade com uma ilustração de um código de barras e alguns questionamentos sobre o princípio de funcionamento dos leitores ópticos, como eles conseguem armazenar as informações e qual a finalidade desse processo. Essa situação corresponde à Organização Praxeológica de referência explorada na OP didática. 


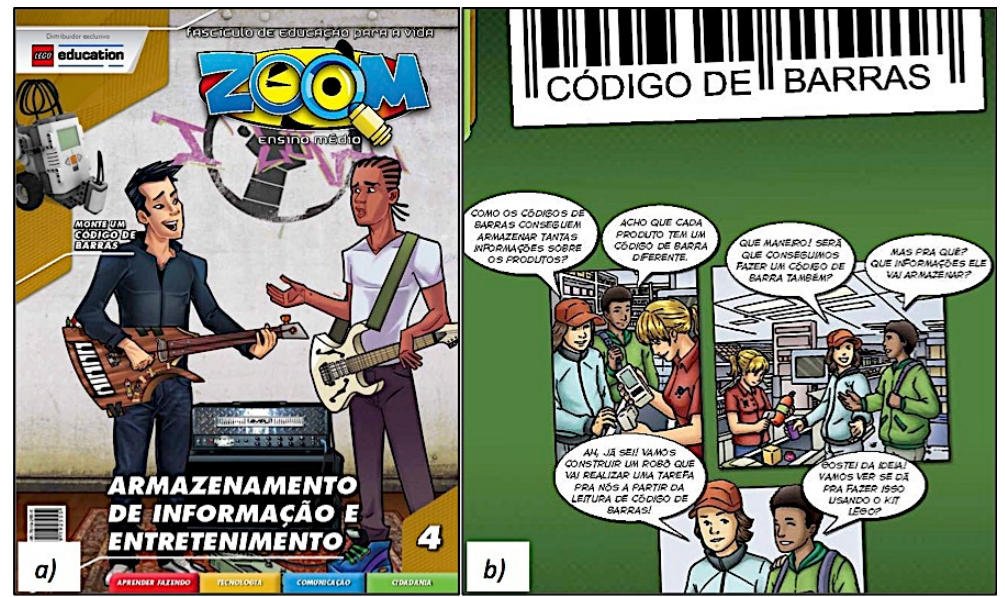

Figura 17 - a) Capa do fascículo Armazenamento de Informação e Entretenimento.

b) HQ de abertura da atividade Código de barras.

A tarefa ou problema central consiste em confeccionar um código de barras para armazenar informações sobre direções e sentidos de movimento pré-determinados pelos alunos. É proposta a montagem de um veículo robô equipado com um sensor óptico (Figura 18a) responsável por ler e decodificar o código. A tarefa do robô será chegar aos objetos A e B, um de cada vez, a partir de um mapa (Figura 18b), podendo seguir qualquer trajetória possível, previamente escolhida pelo grupo. A programação é previamente fornecida pelo professor e inserida no NXT, principalmente por ser complexa e porque demandaria muito tempo dos alunos para desenvolvê-la.

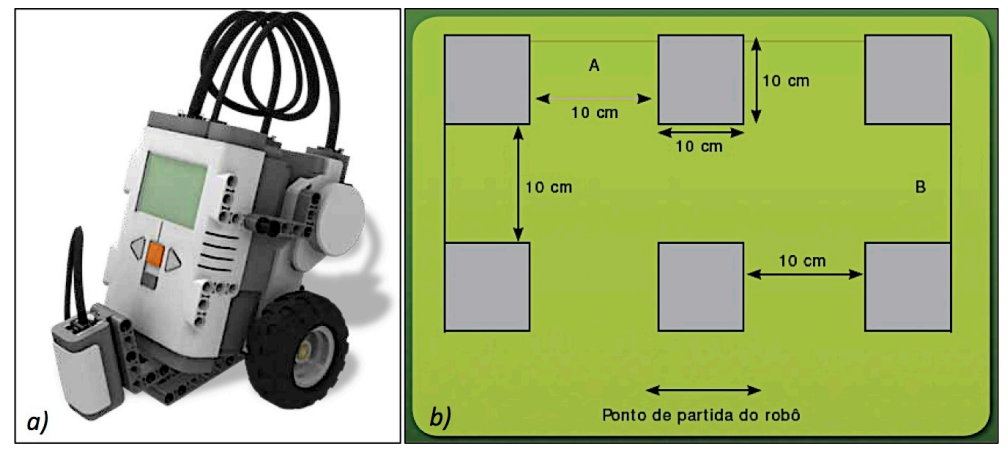

Figura 18 - a) Veículo robô que simula um leitor de código de barras. b) Mapeamento do "labirinto" por onde o veículo deve deslocar-se.

O veículo robô deverá executar os movimentos planejados após decodificar o código de barras criado pelo grupo. Diferente dos códigos de barra identificados nos produtos vendidos em supermercados e demais lojas, o padrão desenvolvido pelos alunos deve ser formado por um conjunto de barras verticais com mesma largura, preenchidas entre si ou não. Quando o veículo passar sobre elas (realizando a leitura do código apenas da esquerda para a direita), a leitura de uma barra clara será convertida no número 0 e a de uma barra escura no número 1, formando um sistema binário a partir da combinação das barras. Para que o veículo 
robô possa movimentar-se pelas trajetórias escolhidas, a equipe deverá pintar a sequência de faixas pretas verticais do código de barras (Figura 19a) a partir de um código de referência de 4 bits que determina o sentido de cada movimento (Figura 19b).

A Tabela ASCII (Código Padrão Americano para o Intercâmbio de Informação) também é discutida nessa atividade, em que os alunos são indagados como fariam um código de barras de 8 bits para informar ao robô um conjunto determinado de caracteres.

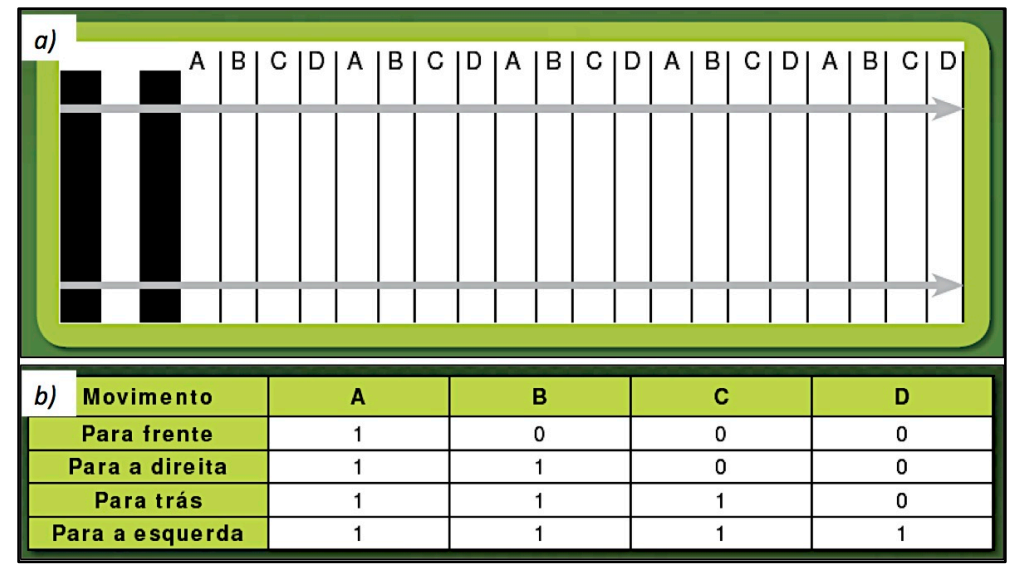

Figura 19 - a) Código de barras que deverá ser confeccionado. b) Código binário de 4 bits para movimento do robô.

Por fim, como prática opcional ou de extensão, é solicitado aos alunos determinarem quantos códigos com combinações de 4 bits é possível fazer para o robô partir, chegar ao ponto A e, depois, em B, pelas trajetórias permitidas no mapa. Além disso, são apresentadas questões adicionais do Exame Nacional do Ensino Médio e de vestibulares que exploram o uso de código de barras para armazenamento de informações.

\section{2 - Sistematização e comparação das Organizações Praxeológicas}

Tanto a análise da OP de referência quanto da OP didática demandam uma sistematização e organização para expor, de maneira organizada e estruturada, os principais constituintes praxeológicos $(\mathrm{T}, \tau, \theta$ e $\Theta$ ) identificados e/ou considerados mais relevantes em cada uma. Para isso, faremos uso de Mapas Conceituais (MC) (NOVAK \& CAÑAS, 2010, 2008), ferramenta gráfica originalmente desenvolvida para analisar as representações conceituais estabelecidas por alunos sobre tópicos em ciências da escola básica (NOVAK \& MUSONDA, 1991).

Os mapas conceituais (MC) podem servir também "para acompanhar o processo de mudança conceitual ao longo da instrução, para verificar a organização dos conceitos numa 
disciplina e para avaliar grades curriculares" (ibidem, p.1). Porém, hoje seu uso é variado e utilizado em diversos setores (NOVAK \& CAÑAS, 2010), desde computação e engenharia de software até "em corporações para ajudar equipes a esclarecer e articular o conhecimento necessário para enfrentar situações que variam desde o desenho de novos produtos até o marketing ou a resolução de problemas.” (NOVAK \& CAÑAS, 2008, p. 18).

A Figura 20 apresenta um mapa conceitual para explicar justamente o que são mapas conceituais e suas principais características (CORREIA, SILVA \& ROMANO JUNIOR, 2010).

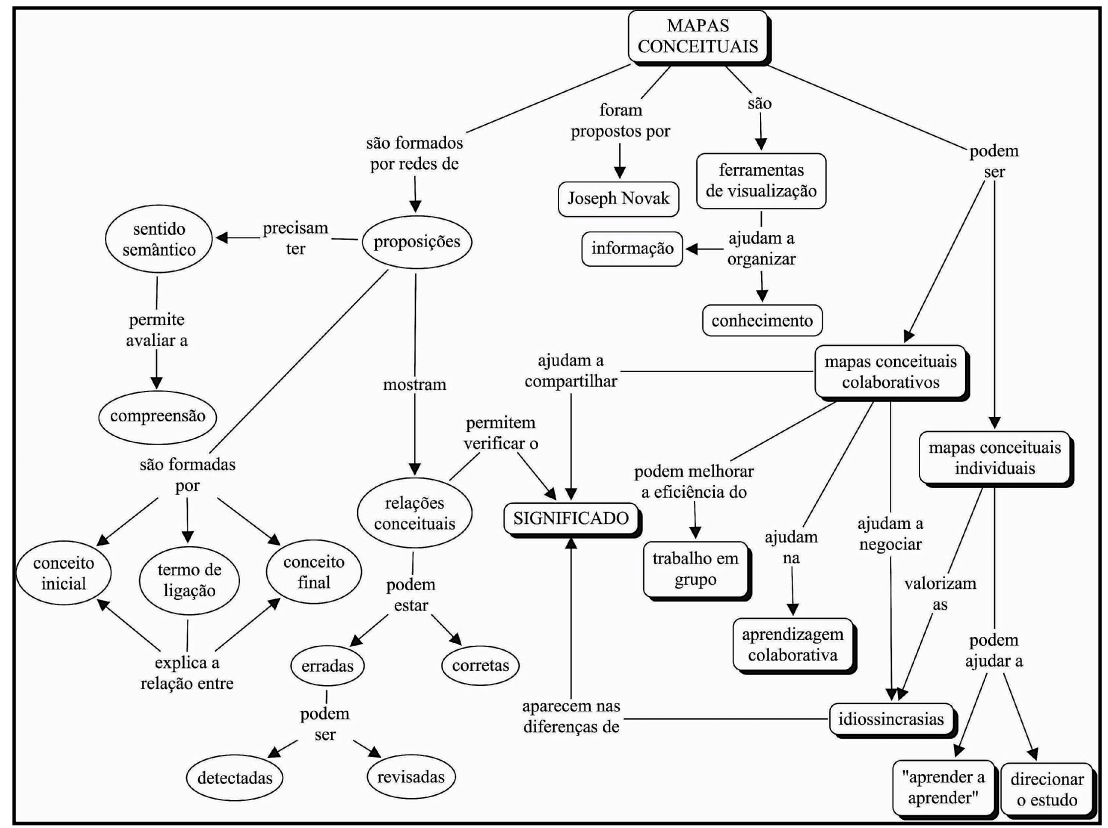

Figura 20 - Mapa conceitual sobre Mapas Conceituais. Fonte: CORREIA, SILVA \& ROMANO JUNIOR, 2010.

Como os mapas conceituais permitem organizar e representar o conhecimento através da relação entre conceitos, interligados por palavras ou frases que especificam esse relacionamento, constatamos que eles podem, dentre outras coisas, fomentar uma reflexão mais profunda e sutil para a determinação dos referidos constituintes praxeológicos.

Apesar da possibilidade de investigação do processo de aprendizagem via os MC, a apropriação dessa ferramenta limitar-se-á ao aspecto organizacional e estrutural das OP didática e de referência, ou seja, para ajudar no processo de organização, estruturação e exibição das informações referentes as duas OP.

Basicamente, faremos o estudo da OP de referência por meio de artigos, livros, documentários, consulta a especialistas, etc., para então levantar os principais tipos de tarefas e as técnicas adotadas, bem como tecnologias e teorias contidas na OP investigada. Em 130 
seguida, todos os principais conceitos identificados na OP de referência serão agrupados e organizados pelo MC através dos termos de ligação. O mesmo processo é realizado para representar a $\mathrm{OP}$ didática via $\mathrm{o} \mathrm{MC}$, porém, limitado à própria sequência didática, ou seja, aos conteúdos disciplinares e procedimentos em geral expressos no fascículo ou guia da atividade. Esses dois mapas conceituais, da OP didática e da OP de referência, são então "comparados" no intuído de se verificar possíveis níveis de ressonância, ou seja, verossimilhanças praxeológicas por correspondência ou por interseção, como definidos no capítulo 3 .

Por fim, é preciso ressaltar que a questão focal, a qual "guia" o desenvolvimento do MC, deve ser similar para cada OP, do contrário, pode-se gerar mapas conceituais completamente diferentes, impossibilitando que sejam "contrastados". A essência dessa estratégia metodológica é sempre gerar questões no MC da OP didática de modo a poder contrapor com as informações do $\mathrm{MC}$ da $\mathrm{OP}$ de referência, na tentativa de se identificar possíveis verossimilhanças praxeológicas.

\section{3 - Sistematização e representação dos Momentos didáticos: análise com o Videograph}

Conforme discutimos anteriormente, os momentos didáticos (ou de estudo) podem surgir ao longo da(s) aula(s) de maneira não cronológica, ou seja, pode-se estar no momento de trabalho da técnica e voltar para o momento do primeiro encontro ou exploratório, e depois saltar para o momento da institucionalização. Além disso, pode-se permanecer por mais tempo nesse ou naquele momento. Dessa forma, é preciso alguma estratégia que permita exibir uma espécie de "raio X" da aula, ou seja, algo que possibilite "visualizar" a ocorrência e duração desses momentos ao longo das aulas.

Uma forma interessante que identificamos para apresentar tais ocorrências e duração é através do software Videograph ${ }^{24}$. Em pesquisas sobre a estruturação matemática no ensino de física, Karam (2012) diz que "a utilização do software videograph possibilitou um olhar mais detalhado para o fenômeno, levando à identificação/definição de categorias de análise e posteriormente a uma representação dinâmica da interação entre as mesmas numa escala temporal." (ibidem, p. 71). A Figura 21 ilustra a interface desse software durante a categorização. Cada categoria é apresentada em "faixas" e com coloração específica.

\footnotetext{
${ }^{24}$ Software Videograph: http://www.ipn.uni-kiel.de/aktuell/videograph/enhtmStart.htm Acesso em 2 de abril de 2013.
} 


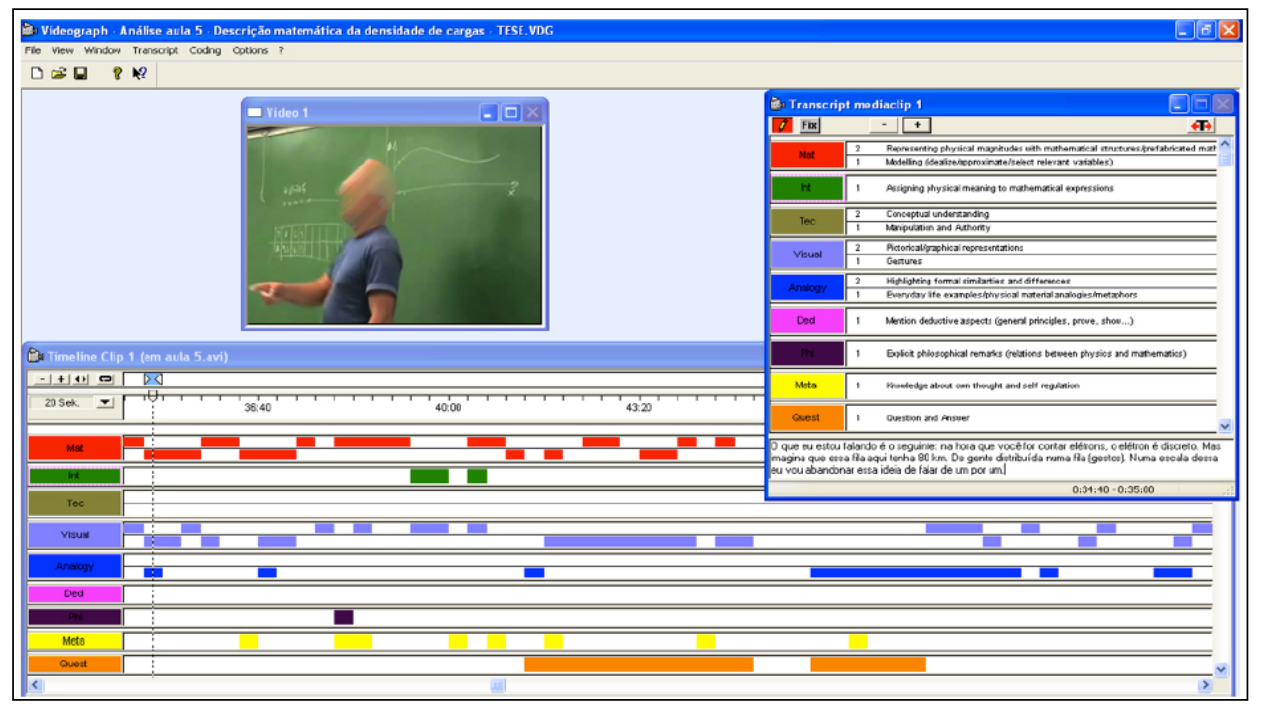

Figura 21 - Interface do Videograph durante a categorização. Fonte: Karam (2012, p. 85).

Os dados gerados podem ser apresentados graficamente e transferidos para um arquivo externo. Segue exemplo de um diagrama gerado pelo Videograph (Figura 22), no qual são apresentadas as categorias identificadas no extrato de uma aula e em quais tempos elas surgem no decorrer da aula.

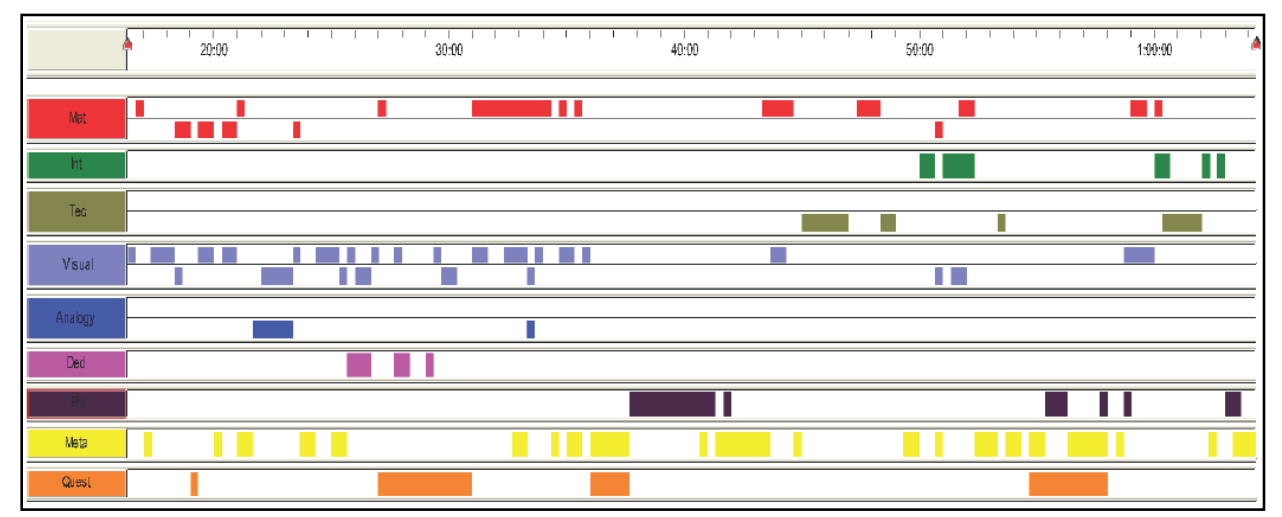

Figura 22 - Exemplo de diagrama gerado pelo Videograph. Fonte: Karam (2012, p. 167).

Podemos considerar os próprios momentos didáticos como as categorias a serem investigadas nas aulas. Em linhas gerais, no caso da contextualização no ensino de Física por meio da robótica educacional, pode-se considerar algumas ações como características desse ou aquele momento didático, por exemplo: quando o educando tem acesso livre ao processo de montagem do "robô", podendo optar por qual peça e componente eletromecânico utilizar para resolver uma determinada tarefa (momento exploratório); apresentação de tarefas e problemas originários de uma determinada prática social de referência (momento do primeiro encontro); aplicação de um pré e pós-teste (momento da avaliação). 
Uma prática social de referência que envolve o transporte de cargas através de maquinários e dispositivos mecânicos, por exemplo, pode apresentar tarefas ou problemáticas que servem de elo para fomentar o primeiro encontro. Assim, o transporte seguro e estável de uma determinada carga, usando empilhadeiras, pode configurar-se numa problemática ou tarefa inicial, na qual o estudante tem normalmente relações fictícias com o objeto (empilhadeira, transporte de carga, estabilidade, etc.) daquela OP de referência. Depois, ao se questionar sobre a razão de ser desses objetos em tal organização - Qual a função do contrapeso e do fulcro? Por que a carga tem que estar disposta desse e não daquele modo? Por que esse limite não pode ser extrapolado? -, o aluno entra em situações fundamentais que conduzem o indivíduo a propor definições e conceitos complexos, “convenientes" para a OP didática.

Para efetivar ou iniciar o processo de contextualização, o problema (ou tarefa) apresentado na OP didática deve estar vinculado (direta ou indiretamente) a uma OP de referência. Assim, por meio de instrumentos da robótica educacional, o indivíduo pode explorar inicialmente as possibilidades e estratégias oferecidas pelo material. Em outras palavras, ele pode utilizar sensores, motores e dispositivos mecânicos e elétricos para construir réplicas ou situações que o permitam investigar o problema proposto e chegar a uma solução. Dependendo do material utilizado (baixo custo, recicláveis, open source, modulares, programáveis, etc.) e da intenção didática do professor, o momento exploratório pode apresentar uma vasta gama de estratégias para resolução de um único problema. Uma problemática que exige a determinação da velocidade de um veículo, por exemplo, pode ser explorada inicialmente e resolvida fazendo uso de diferentes sensores (ópticos, ultrassom, contato, efeito hall, etc.) dispostos das mais diferentes formas (similares a OP de referência ou não). Nessa exploração inicial, é preciso se valer de técnicas adequadas para melhor resolução da tarefa proposta, por exemplo: o uso de um sensor de ultrassom para determinação da velocidade de um veículo não obedece ao mesmo procedimento (algoritmo de programação, configuração, limites de detecção, etc.) em comparação ao uso de um sensor óptico para o mesmo fim, serão necessárias técnicas específicas para a correta determinação da velocidade dependendo do sensor adotado. Isso tudo permeia o momento exploratório.

Portanto, pretendemos investigar a dinâmica dos momentos didáticos quando inseridos num processo de contextualização mais específico, ou seja, fazendo uso de recursos didáticos diferenciados como é o caso da robótica educacional. Há momentos que são priorizados elou se sobrepõem aos demais? Há situações que evidenciam deficiências no processo de 
contextualização nesse cenário de inovação? Se sim, quais e por que ocorrem? Em contrapartida, há situações que favoreçam esse processo de contextualização em tal cenário? Se sim, como? Essas são algumas das questões que pretendemos investigar ao efetuar a análise dos momentos didáticos. Para isso, utilizamos Videograph para análise das aulas, e apresentamos na tabela a seguir (Tabela 5) algumas ações que consideramos diretamente vinculadas aos momentos didáticos de acordo com as definições discutidas anteriormente, gerando, assim, as categorias que serão analisadas.

Tabela 5 - Categorização dos momentos de estudo usando o software Vídeograph.

\begin{tabular}{|c|c|c|c|}
\hline Categoria & Cor & $\begin{array}{l}\text { Momento } \\
\text { didático }\end{array}$ & Principal ação indicativa \\
\hline $\begin{array}{c}1 \\
\text { [Encontro] }\end{array}$ & Amarelo & Primeiro encontro & $\begin{array}{l}\text { - apresentação da práxis e/ou logos presentes em } \\
\text { uma dada prática social de referência que compõe a tarefa } \\
\text { ou problemática central; } \\
\text { - manipulação inicial pelo educando de objetos } \\
\text { (equações, conceitos, leis, expressões matemáticas, } \\
\text { ferramentas, maquinários, etc.) de uma determinada OP } \\
\text { (física, matemática, química, didática, artesã, industrial, } \\
\text { etc.). }\end{array}$ \\
\hline $\begin{array}{c}2 \\
\text { [Explor] }\end{array}$ & Verde & Exploratório & $\begin{array}{l}\text { - livre escolha e utilização de materiais ou } \\
\text { dispositivos para desenvolvimento de montagens que } \\
\text { objetivam investigar uma determinada tarefa ou } \\
\text { problemática; } \\
\text { - questionamentos e análises (individual ou coletiva) } \\
\text { sobre qual(is) técnica(s) mais apropriada(s) para resolver a } \\
\text { tarefa ou problema em pauta. }\end{array}$ \\
\hline $\begin{array}{c}3 \\
{[\text { Tec-Teor }]}\end{array}$ & Laranja & $\begin{array}{l}\text { Tecnológico- } \\
\text { teórico }\end{array}$ & $\begin{array}{l}\text { - explicações, questionamentos e análises sobre a } \\
\text { razão de ser da(s) técnica(s) adotada(s) para resolver a } \\
\text { tarefa ou problema em pauta. }\end{array}$ \\
\hline $\begin{array}{c}4 \\
\text { [Técnica] }\end{array}$ & Azul & $\begin{array}{l}\text { Trabalho da } \\
\text { técnica }\end{array}$ & $\begin{array}{l}\text { - desenvolvimento de montagens específicas } \\
\text { utilizando dispositivos pré-determinados para investigar } \\
\text { uma determinada tarefa ou problemática; } \\
\text { - manipulação efetiva (por parte dos alunos e/ou } \\
\text { professor) de objetos (equações, conceitos, leis, expressões } \\
\text { matemáticas, ferramentas, maquinários, etc.) de uma } \\
\text { determinada OP para solucionar, de fato, a tarefa ou } \\
\text { problemática em questão; }\end{array}$ \\
\hline $\begin{array}{c}5 \\
\text { [Instituc] }\end{array}$ & Marrom & Institucionalização & $\begin{array}{l}\text { - oficialização e destaque (expressa no quadro ou } \\
\text { verbalizada pelo professor) dos principais objetos que estão } \\
\text { de acordo e coesos com a OP em questão; } \\
\text { - modificações em geral da práxis e/ou do logos da } \\
\text { OP em questão, simplificando-a, enriquecendo-a, etc. }\end{array}$ \\
\hline $\begin{array}{c}6 \\
{[\text { Aval] }}\end{array}$ & Vermelho & Avaliação & $\begin{array}{l}\text { - aplicação de testes e reflexões em que é posto à } \\
\text { prova o domínio e validade do conhecimento teórico } \\
\text { adquirido e das técnicas adotadas por trás das tarefas } \\
\text { realizadas. }\end{array}$ \\
\hline
\end{tabular}


Quanto ao ambiente de aplicação das atividades, optamos por duas turmas do primeiro ano do ensino médio do Colégio Modelo Luís Eduardo Magalhães (colégio público estadual), situado em Ilhéus/BA. O colégio oferece espaço próprio para aplicação (laboratório de física) e contamos com boa receptividade da direção e do professor de Física responsável pelas turmas. Todas as aplicações (total de três) ocorreram aos sábados, com duração média aproximada de 3 horas e meia, e participação voluntária dos alunos das referidas turmas. Vale salientar ainda que o professor responsável pelas turmas, que aplicou as atividades "empilhadeiras" e "colisões", já desenvolve trabalhos extracurriculares nesse colégio (como, por exemplo, lançamentos de foguete d'água, construído pelos próprios alunos sob sua orientação) e possui relativa experiência com instrumentos da robótica educacional, mais especificamente, com a plataforma de prototipagem Arduino.

Apresentado os aspectos metodológicos da pesquisa, os materiais e métodos de análise e campo de aplicação das atividades para estudo dos momentos didáticos, passamos agora para o capítulo 5, onde são apresentados e discutidos os principais resultados obtidos. 


\section{Capítulo 5 - RESUlTADOS E DISCUSSÕES}

Posso saber pedagogia, biologia como astronomia, posso cuidar da terra como posso navegar. Sou gente. Sei que ignoro e sei que sei. Por isso, tanto posso saber o que ainda não sei como posso saber melhor o que já sei. E saberei tão melhor e mais autenticamente quanto mais eficazmente construa minha autonomia em respeito à dos outros.

Paulo Freire $^{25}$

\section{1 - Análise praxeológica da OP didática}

A análise praxeológica realizada e apresentada nesse capítulo tem dois objetivos principais. O primeiro é identificar possíveis correlações entre o bloco tecnológico-teórico e o bloco prático-técnico na OP didática, ou seja, entre o "fazer" e as teorias e os conceitos físicos tratados na OP didática (o "porquê") de modo a favorecer a aprendizagem de conteúdos científicos e estimular o aluno a refletir e interligar teoria e prática. O segundo objetivo remete a contextualização, busca identificar correlações praxeológicas entre a OP didática e a OP de referência. Assim, é possível investigar o quanto a OP didática dialoga (ou não) com a situação que se deseja contextualizar (prática social de referência), além de possibilitar uma compreensão mais detalhada da sua estrutura e da coerência interna e externa da atividade em termos das tarefas, técnicas, tecnologias e teorias.

25 In. Pedagogia da Autonomia. 36ª edição, São Paulo: Editora Paz e Terra, 2007, p. 94. 
Essencialmente, procurou-se localizar na OP (física, matemática, química, biológica, computacional, artesã, rural, industrial, didática, política, etc.) objetos (equações, questionamentos, conceitos, leis, expressões matemáticas, ferramentas, maquinários, etc.) que evidenciem (de forma explícita ou não) as técnicas, tecnologias e teorias mais adequadas para a realização e compreensão das tarefas e tipos de tarefas necessárias para investigar determinada fenômenos físicos e/ou resolver um problema.

Interpretamos que, por meio da análise praxeológica, se não for identificada na OP didática a ocorrência de ao menos uma parte do bloco tecnológico-teórico (como a tecnologia, por exemplo), implica dizer que a modelização do conhecimento poderá não ser contemplada. Isso ocorre porque dificilmente haverá mobilização dos saberes disciplinares necessários para melhor compreender e/ou solucionar a situação posta na problematização. Isso pode prejudicar o processo de contextualização uma vez que, por meio da OP didática, o indivíduo possivelmente não será capaz de alterar ou criar relações com objetos contidos em diferentes organizações praxeológicas, não promovendo, assim, a relação $R(X, O) \Leftrightarrow R\left(X, O_{n}\right)$. Desse modo, a contextualização não será eficaz e possivelmente servirá apenas como mera ilustração ou exemplo de uma dada realidade, sem maiores compromissos disciplinares em termos conceituais e teóricos.

Essa investigação mais profunda envolvendo a OP de referência é tratada mais adiante, primeiramente, faremos uma exposição dos principais constituintes praxeológicos (tipos de tarefa, tarefas, técnicas, dentre outros.) identificados em cada OP didática (Empilhadeiras, Colisões, Sismógrafo e Código de barras).

Importante ressaltar que há uma vasta gama de outros tipos de tarefas presentes no decorrer do processo de ensino-aprendizagem, como o próprio ato de ler e escrever, falar e comunicar-se, interagir socialmente, efetuar pequenas operações numéricas e/ou literais, dentre outras, cada uma envolvendo determinadas técnicas e tecnologias. Contudo, podemos considerá-las como uma espécie de pré-requisitos da atividade, por essa razão, focamos nosso estudo nos tipos de tarefas expoentes identificados na OP didática e de referência, ou seja, naquelas principais que lançam o individuo para solucionar determinado problema e/ou questão.

As questões ou desafios que são apresentados ao término da atividade não serão inclusos para análise tendo em vista se tratar de atividades opcionais e/ou de extensão, além disso, o corpo principal da atividade já apresenta material suficiente para atender aos 
objetivos da pesquisa.

\subsection{1 - Atividade "Empilhadeiras"}

Após a problematização inicial, em que se discute o transporte de carga por meio das empilhadeiras e sobre seu princípio físico de funcionamento, correlacionando-o com uma gangorra, há dois momentos particulares (Figura 23). O primeiro destina-se à montagem dos contentores e da empilhadeira propriamente dita (seguindo as instruções de um manual de montagem) e o segundo está relacionado à programação (fornecida pelo professor, mas que pode ser alterada e desenvolvida pelos alunos). De acordo com a TAD, podemos afirmar que estas duas fases correspondem a dois tipos de tarefas distintas (montar e programar), porém, complementares, $\mathrm{T}_{1}$ e $\mathrm{T}_{2}$.

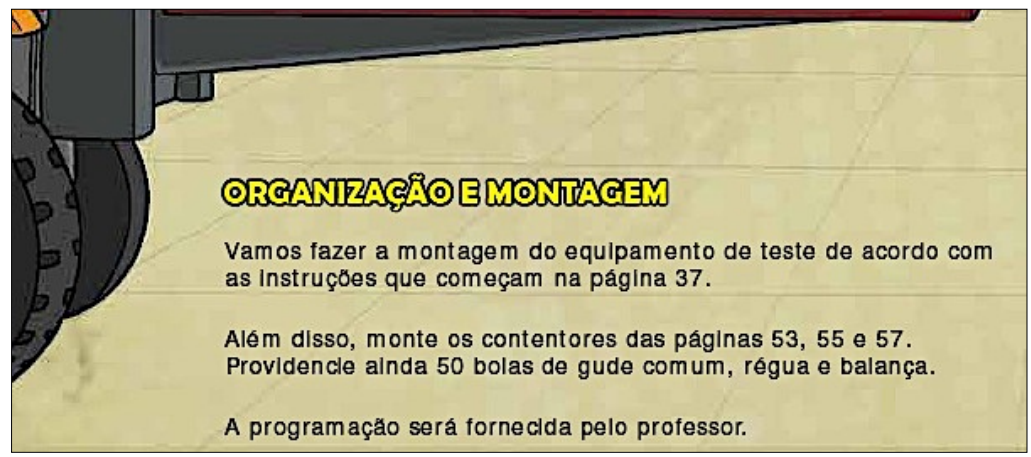

Figura 23 - Extrato do fascículo da atividade "Empilhadeiras" em que se identificam dois tipos de tarefa $\left(\mathrm{T}_{1}\right.$ e $\left.\mathrm{T}_{2}\right)$.

Em seguida, conforme aponta o extrato do fascículo ilustrado na Figura 24, identificase outro tipo de tarefa $\left(T_{3}\right)$, ou seja, transportar a carga. Deve-se transportar uma mesma quantidade de carga (bolinhas de gude) utilizando três tipos de contentores (pequeno, médio e grande).

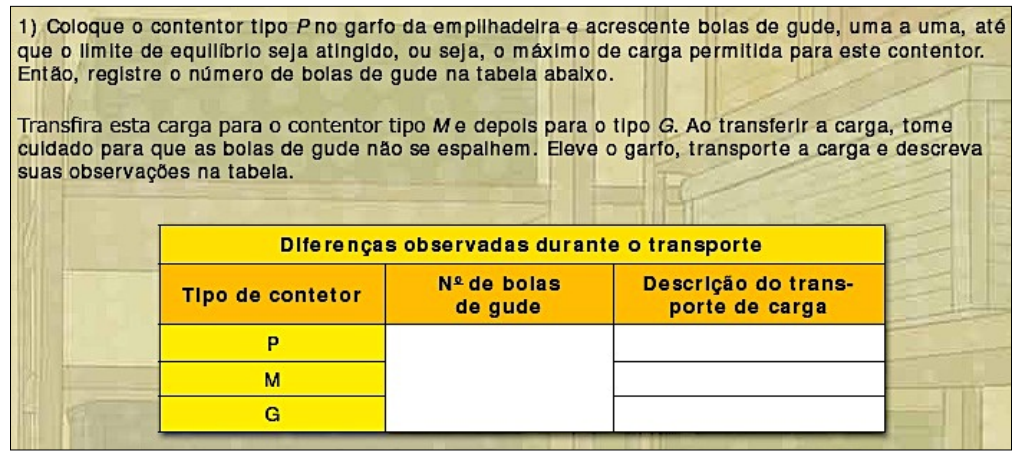

Figura 24 - Extrato do fascículo da atividade "Empilhadeiras" em que se identifica $\mathrm{T}_{3}$. 
É solicitado também investigar-se a quantidade máxima de carga permitida a ser transportada pela empilhadeira, para cada tipo de contentor. Nessa mesma linha de raciocínio, o fascículo do aluno discute a capacidade máxima de carga a ser transportada pela empilhadeira em função da distância entre o centro de gravidade da carga e o ponto de apoio (ou fulcro). Assim, podemos afirmar que essas duas tarefas compõem uma mesma ação, ou seja, analisar a carga máxima suportada pela empilhadeira, configurando-se, desse modo, no tipo de tarefa $T_{4}$. Porém, esse tipo de tarefa desdobra-se em outras duas tarefas $\left(t_{41}\right.$ e $\left.t_{42}\right)$, ou seja, verificar experimentalmente qual a carga máxima suportada para ser transportada pelos contentores tipo P, M e G (Figura 25) e investigar a relação entre capacidade de carga e o centro de carga (Figura 26).

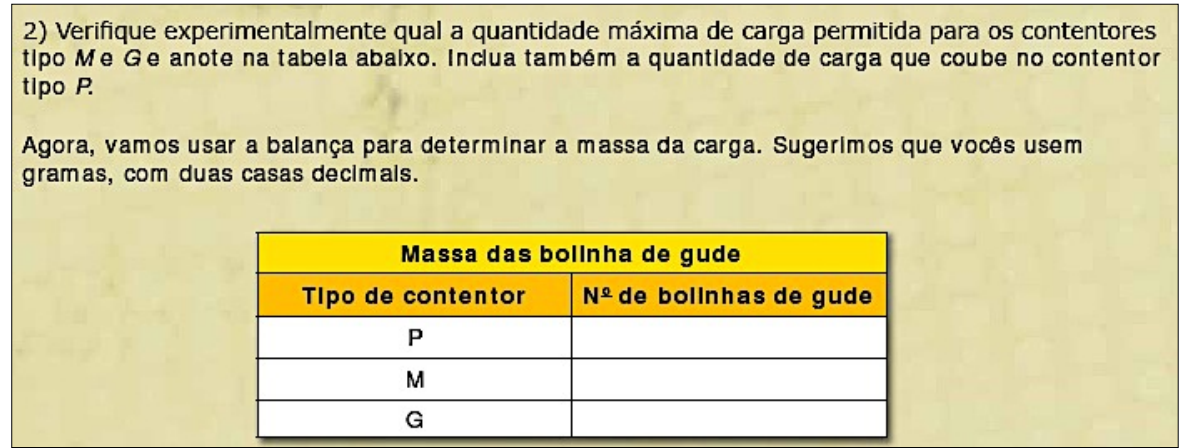

Figura 25 - Extrato do fascículo da atividade "Empilhadeiras" em que se identifica a tarefa $t_{41}$.

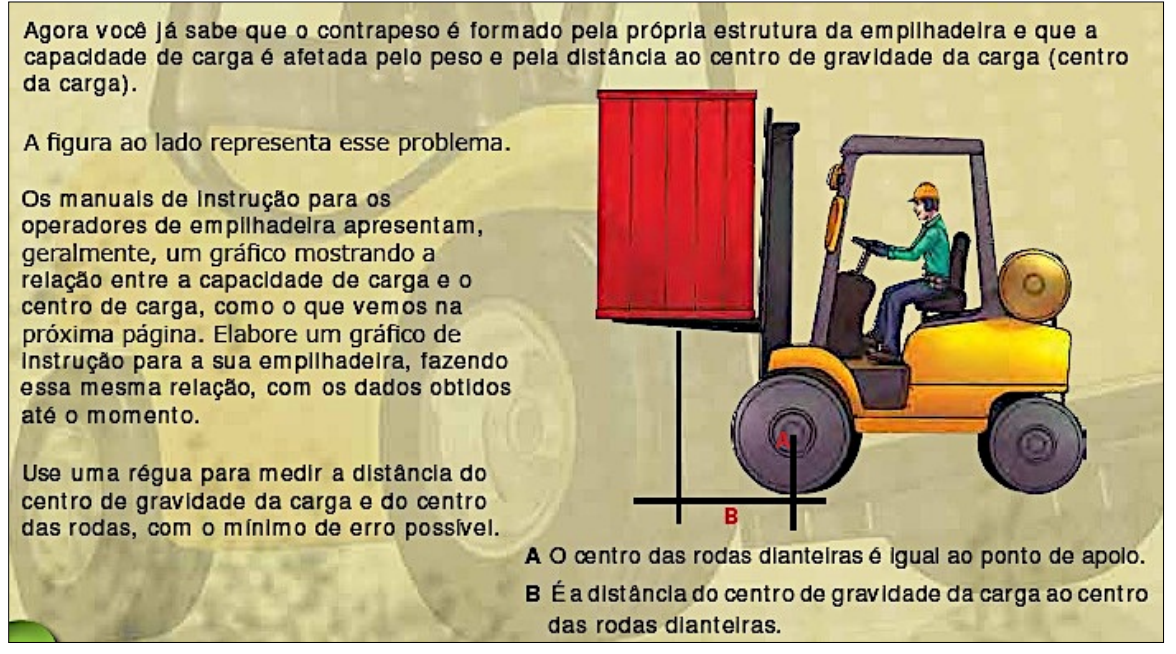

Figura 26 - Extrato do fascículo da atividade "Empilhadeiras" em que se identifica a tarefa $t_{42}$.

Apresentamos na Tabela 6 os principais tipos de tarefa (T) presentes na atividade "Empilhadeiras" e sua respectiva tarefa $[\mathrm{t}]$ atribuída/identificada para cada T. Em seguida, a Tabela 7 apresenta as técnicas e tecnologias identificadas para a realização de cada tarefa. 
Tabela 6 - Atividade "Empilhadeiras" em termos de tipos de tarefa e tarefas.

\begin{tabular}{|c|l|}
\hline Tipo de Tarefa (T) & \multicolumn{1}{c|}{ Tarefa (t) } \\
\hline $\begin{array}{c}\mathrm{T}_{1}-\text { Construir uma } \\
\text { Empilhadeira. }\end{array}$ & $\begin{array}{l}\mathrm{t}_{11}-\text { Construir uma empilhadeira com torre de elevação para transportar } \\
\text { uma determinada carga (bolinhas de gude). }\end{array}$ \\
\hline $\begin{array}{c}\mathrm{T}_{2}-\text { Programar o } \\
\text { NXT. }\end{array}$ & $\begin{array}{l}\mathrm{t}_{21}-\text { Programar o NXT para acionar o movimento da torre de elevação } \\
\text { e da própria empilhadeira. }\end{array}$ \\
\hline $\begin{array}{c}\mathrm{T}_{3}-\text { Transportar } \\
\text { Cargas. }\end{array}$ & $\begin{array}{l}\mathrm{t}_{31}-\text { Transportar uma mesma quantidade de bolinhas de gude com a } \\
\text { Empilhadeira em três situações distintas: com contentor tipo } \mathrm{P}, \mathrm{M} \text { e } \mathrm{G} .\end{array}$ \\
\hline \multirow{2}{*}{$\begin{array}{c}\mathrm{T}_{4}-\text { Analisar a carga } \\
\text { máxima suportada } \\
\text { pela empilhadeira. }\end{array}$} & $\begin{array}{l}\mathrm{t}_{41}-\text { Verificar experimentalmente qual a carga máxima suportada para } \\
\text { ser transportada pelos contentores tipo } \mathrm{P}, \mathrm{M} \text { e G. }\end{array}$ \\
\cline { 2 - 2 } & $\mathrm{t}_{42}-$ Investigar a relação entre capacidade de carga e centro de carga. \\
\hline
\end{tabular}

Tabela 7 - Atividade "Empilhadeiras" em termos de técnicas e tecnologias.

\begin{tabular}{|c|c|c|}
\hline Tarefa (t) & Técnica $(\tau)$ & Tecnologias $(\theta)$ \\
\hline $\mathrm{t}_{11}$ & $\begin{array}{l}\tau_{1} \text { - Utiliza-se o kit Lego NXT Mindstorms e o } \\
\text { guia da atividade, que apresenta passo-a-passo } \\
\text { os esquemas de montagem. O texto traz um } \\
\text { rígido procedimento para que o aluno possa } \\
\text { cumprir } \mathrm{t}_{1} \text { Usa-se motores, a bateria e o próprio } \\
\text { NXT para servir de contrapeso. }\end{array}$ & $\begin{array}{l}\theta_{1}-\text { Elementos da mecatrônica, } \\
\text { como desenho técnico mecânico, } \\
\text { cinemática e elementos de } \\
\text { máquinas. }\end{array}$ \\
\hline $\mathrm{t}_{21}$ & $\begin{array}{l}\tau_{2}-\text { Utiliza-se o Lego NXT Mindstorms } \\
\text { Software para desenvolvimento da } \\
\text { programação, previamente fornecida pelo } \\
\text { professor. Resta ao aluno apenas inserir o } \\
\text { programa no NXT. }\end{array}$ & $\theta_{2}$ - Lógica de Programação. \\
\hline$t_{31}$ & \multirow{2}{*}{$\begin{array}{l}\tau_{3} \text { - Apoiar o contentor no "garfo" da } \\
\text { empilhadeira, variando a distância entre o } \\
\text { ponto de apoio do centro de massa da carga } \\
\text { (determinado pelo tamanho do contentor e } \\
\text { distribuição da carga), configurando assim no } \\
\text { braço de alavanca. }\end{array}$} & \multirow[b]{2}{*}{$\begin{array}{l}\theta_{3}-\text { Adoção do princípio da } \\
\text { alavanca. }\end{array}$} \\
\hline $\mathrm{t}_{41}$ & & \\
\hline $\mathrm{t}_{42}$ & 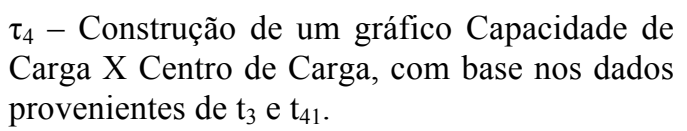 & $\begin{array}{l}\theta_{4}-\text { Funções matemáticas e } \\
\text { Gráficos. }\end{array}$ \\
\hline
\end{tabular}

O discurso central dessa OP didática se limita ao elemento $\theta_{3}$, voltado para "explicar" a técnica $\tau_{3}$, a qual, por sua vez, permite o cumprimento das tarefas $t_{31}$ e $t_{41}$ de modo mais eficaz.

Apesar de ser mais sutil, podemos identificar na lei de conservação da energia o elemento $\Theta_{3}$ (teoria associada a técnica $\theta_{3}$ ), pois ao mesmo tempo em que o contrapeso da empilhadeira realiza trabalho, aplicando uma força peso sobre uma das extremidades do braço de alavanca responsável pela potência, a outra extremidade realiza trabalho sobre a carga, 
mantendo a empilhadeira em equilíbrio estável. Porém, esta oportunidade de discussão e debate não é explicitada no fascículo. Identifica-se a existência de uma organização praxeológica local (CHEVALLARD, 1999), com tarefas e técnicas justificadas e compreendidas por um mesmo bloco tecnológico-teórico, mas que não é totalmente aproveitada/explorada na atividade em questão.

\subsection{2 - Atividade "Colisões".}

Conforme aponta o texto abaixo (Figura 27), essa atividade apresenta uma fase destinada à programação (fornecida pelo professor, mas aberta para possíveis alterações por parte dos próprios alunos) e outro à montagem dos veículos para gerar a situação de colisão, o que corresponde a dois tipos de tarefas distintas (montagem e programação), porém, complementares, $\mathrm{T}_{1}$ e $\mathrm{T}_{2}$.

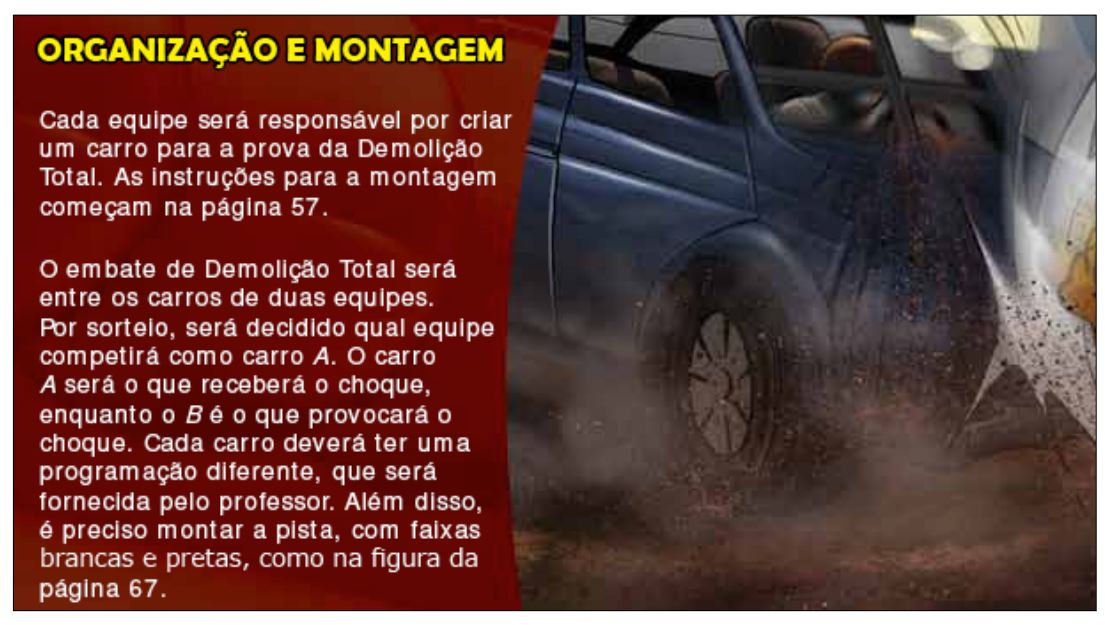

Figura 27 - Extrato do fascículo da atividade "Colisões" em que se identificam dois tipos de tarefa, $\mathrm{T}_{1}$ e $\mathrm{T}_{2}$.

Depois de montados e programados os veículos, bem como posicionados sobre a pista por aonde vão se deslocar linearmente para provocar a colisão frontal, será necessário obter informações sobre a velocidade dos veículos imediatamente antes e depois do choque. Isso será feito através dos sensores de luz, previamente programados, que vão apresentar no display do NXT o tempo que levou para cada veículo se deslocar sobre as faixas escuras que formam a pista. Uma vez conhecendo a largura de cada faixa e considerando que o deslocamento foi linear, o aluno será capaz de efetuar os cálculos e determinar a velocidade ${ }^{26}$ dos carros "A" e "B", antes e depois da colisão, em três situações distintas (massa do carro

${ }^{26}$ Se o professor desejar, a programação pode ser alterada de modo que a velocidade seja calculada automaticamente e apresentada no display do NXT. 
"A" igual, menor e maior que a massa do carro "B"), implicando, desse modo, em um terceiro tipo de tarefa (cálculo da velocidade), $T_{3}$ (Figura 28). Com base nessas informações, além dos dados sobre a massa dos carros "A" e "B", outra tarefa fundamental surge e diz respeito ao cálculo do momento linear antes e depois da colisão nas três situações, gerando, assim, um quarto tipo de tarefa, $\mathrm{T}_{4}$ (Figura 29).

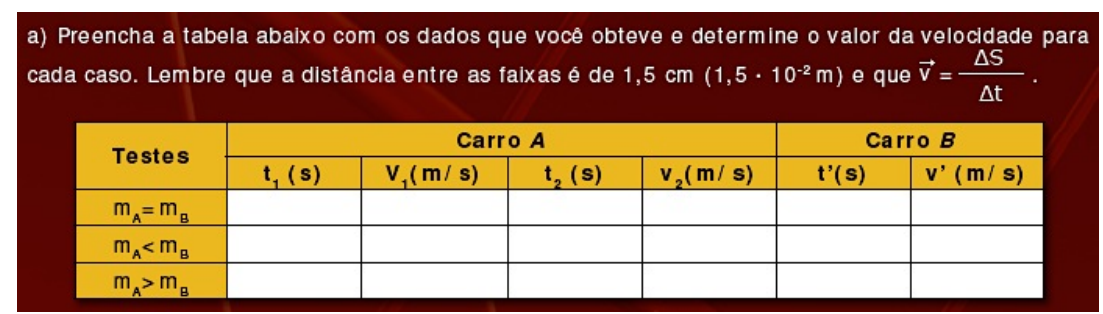

Figura 28 - Extrato do fascículo da atividade "Colisões" em que se identifica o tipo de tarefa $\mathrm{T}_{3}$.

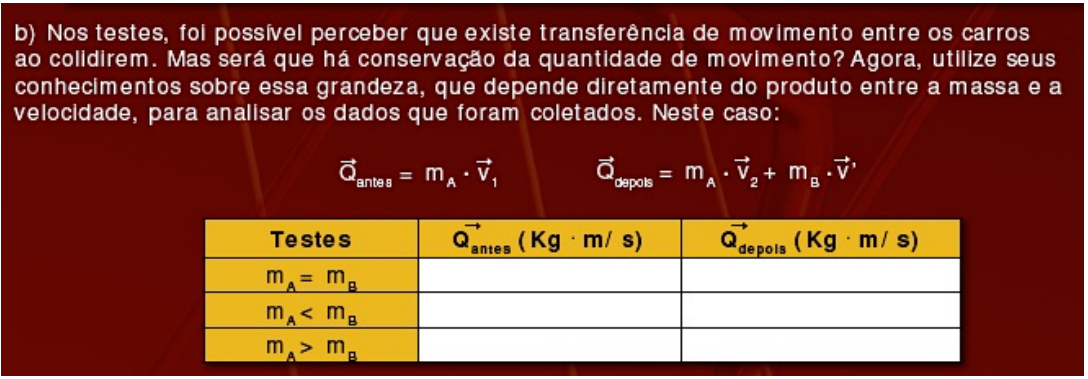

Figura 29 - Extrato do fascículo da atividade "Colisões" em que se identifica o tipo de tarefa $\mathrm{T}_{4}$.

Por fim, identificamos outros dois tipos de tarefa $\left(\mathrm{T}_{5}\right.$ e $\left.\mathrm{T}_{6}\right)$ propostas nessa atividade, uma referente ao valor teórico da velocidade em caso de conservação do momento linear (Figura 30) e outra sobre conservação da energia cinética (Figura 31).

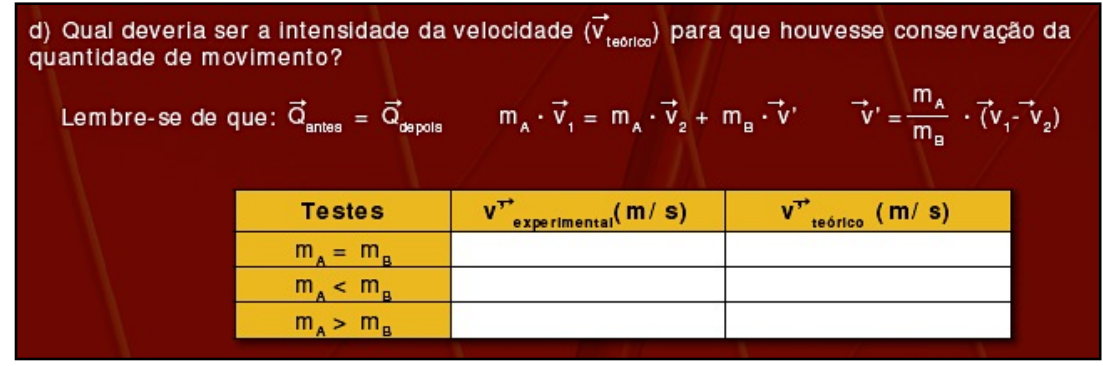

Figura 30 - Extrato do fascículo da atividade "Colisões" em que se identifica o tipo de tarefa $\mathrm{T}_{5}$. 


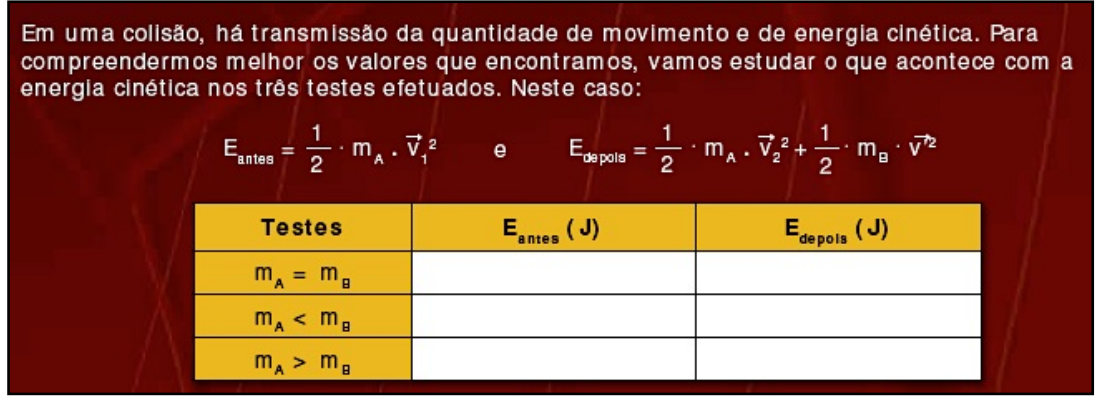

Figura 31 - Extrato do fascículo da atividade "Colisões" em que se identifica o tipo de tarefa $\mathrm{T}_{6}$.

Resumimos na Tabela 8 os principais tipos de tarefa (T) identificados na atividade "Colisões" e sua respectiva tarefa [t] atribuída para cada T. Em seguida, a Tabela 9 trás as técnicas e tecnologias indicadas nessa OP didática para a realização de cada tarefa.

Tabela 8 - Atividade "colisões" em termos de tipos de tarefa e tarefas.

\begin{tabular}{|c|c|}
\hline Tipo de Tarefa (T) & Tarefa $(t)$ \\
\hline \multirow{2}{*}{$\begin{array}{l}\mathrm{T}_{1}-\text { Desenvolver } \\
\text { uma situação de } \\
\text { colisão. }\end{array}$} & $\mathrm{t}_{11}-$ Montar os veículos A e B. \\
\hline & $\begin{array}{l}\mathrm{t}_{12}-\text { Desenvolver uma colisão frontal entre dois veículos }\left(\mathrm{m}_{\mathrm{A}}\right. \\
\text { inicialmente em repouso e } \mathrm{m}_{\mathrm{B}} \text { com velocidade constante) em três } \\
\text { situações distintas: } \mathrm{m}_{\mathrm{A}}=\mathrm{m}_{\mathrm{B}}, \mathrm{m}_{\mathrm{A}}>\mathrm{m}_{\mathrm{B}} \mathrm{e}_{\mathrm{A}}<\mathrm{m}_{\mathrm{B}} \text {. }\end{array}$ \\
\hline \multirow{2}{*}{$\begin{array}{l}\mathrm{T}_{2}-\text { Programar o } \\
\text { NXT. }\end{array}$} & $\begin{array}{l}\mathrm{t}_{21} \text { - Programar o sensor de Luz inserido no carro A para mensurar o } \\
\text { tempo de seu deslocamento imediatamente antes e depois da colisão. } \\
\text { Isso servirá de base para os cálculos posteriores. }\end{array}$ \\
\hline & $\begin{array}{l}\mathrm{t}_{22} \text { - Programar o sensor de Luz inserido no carro B de modo que } \\
\text { possa ser medido sua velocidade imediatamente após a colisão. }\end{array}$ \\
\hline $\begin{array}{l}\mathrm{T}_{3}-\text { Calcular a } \\
\text { velocidade. }\end{array}$ & $\begin{array}{l}t_{31} \text { - Usar os dados sobre o tempo de passagem do veículo por uma } \\
\text { faixa e a largura da mesma para calcular a velocidade de } \mathrm{m}_{\mathrm{A}} \text { e } \mathrm{m}_{\mathrm{B}} \\
\text { imediatamente antes e depois da colisão nas três situações propostas. }\end{array}$ \\
\hline $\begin{array}{l}\mathrm{T}_{4}-\text { Calcular o } \\
\text { momento linear. }\end{array}$ & $\begin{array}{l}\mathrm{t}_{41} \text { - Com base nos dados obtidos, calcular a quantidade de momento } \\
\text { linear de } \mathrm{m}_{\mathrm{A}} \text { e } \mathrm{m}_{\mathrm{B}} \text {, antes e depois da colisão nas três situações } \\
\text { propostas. }\end{array}$ \\
\hline $\begin{array}{l}\mathrm{T}_{5}-\text { Calcular o valor } \\
\text { teórico da } \\
\text { velocidade. }\end{array}$ & $\begin{array}{l}\mathrm{t}_{51} \text { - Calcular o valor teórico da velocidade do carro "A" após a } \\
\text { colisão para o caso em que há conservação da quantidade de } \\
\text { movimento. }\end{array}$ \\
\hline $\begin{array}{l}\mathrm{T}_{6}-\text { Calcular a } \\
\text { Energia Cinética. }\end{array}$ & $\begin{array}{l}\mathrm{t}_{61}-\text { Com base nos dados obtidos, calcular a quantidade de Energia } \\
\text { Cinética total, antes e depois da colisão nas três situações propostas. }\end{array}$ \\
\hline
\end{tabular}


Tabela 9 - Atividade "colisões" em termos de técnicas e tecnologias.

\begin{tabular}{|c|c|c|}
\hline Tarefa $(t)$ & Técnica $(\tau)$ & Tecnologias $(\theta)$ \\
\hline $\mathrm{t}_{11}$ & $\begin{array}{l}\tau_{1} \text { - Utiliza-se o kit Lego NXT Mindstorms e o guia da } \\
\text { atividade, que apresenta passo-a-passo os esquemas de } \\
\text { montagem. O texto traz um rígido procedimento para } \\
\text { que o aluno possa cumprir } \mathrm{t}_{1} \text {. Usam-se objetos de até } \\
100 \text { gramas para agregar à estrutura dos veículos, } \\
\text { alterando suas massas. Eles se deslocam sobre listas } \\
\text { escuras igualmente espaçadas pintadas sobre uma } \\
\text { superfície (plana e horizontal). }\end{array}$ & $\begin{array}{l}\theta_{1}-\text { Elementos da } \\
\text { mecatrônica, como desenho } \\
\text { técnico mecânico, } \\
\text { cinemática e elementos de } \\
\text { máquinas voltados para } \\
\text { desenvolver a situação de } \\
\text { colisão entre veículos em } \\
\text { Movimento Retilíneo } \\
\text { Uniforme (MRU). }\end{array}$ \\
\hline$t_{22}$ & $\begin{array}{l}\tau_{2} \text { - Utiliza-se o Lego NXT Mindstorms Software para } \\
\text { desenvolvimento da programação. Ao aluno cabe } \\
\text { apenas inserir o programa que é fornecido pelo } \\
\text { professor no NXT de cada veículo e conectar demais } \\
\text { componentes eletroeletrônicos. A programação vai } \\
\text { trabalhar com o sensor de luz para armazenar } \\
\text { informações do tempo que o veículo leva para passar } \\
\text { por uma faixa que compõem a pista por onde ele se } \\
\text { desloca. }\end{array}$ & $\begin{array}{l}\theta_{2}-\text { Lógica de Programação } \\
\text { e equações do MRU. }\end{array}$ \\
\hline$t_{31}$ & $\begin{array}{l}\tau_{3} \text { - A principal equação utilizada para o cálculo é a } \\
\text { expressão da velocidade média em } M R U, V_{m}=\Delta S / \Delta t\end{array}$ & \multirow{3}{*}{$\begin{array}{l}\theta_{3}-\text { Leis de Newton, com } \\
\text { ênfase na transferência da } \\
\text { quantidade de movimento. } \\
\text { Adota-se o princípio de } \\
\text { conservação, mas sem } \\
\text { devida justificativa física } \\
\text { (em sistemas isolados, Força } \\
\text { resultante externa é nula). }\end{array}$} \\
\hline $\mathrm{t}_{41}$ & $\begin{array}{l}\tau_{4} \text { - A principal equação utilizada para o cálculo é a } \\
\text { expressão da quantidade de movimento, } \mathrm{Q}=\mathrm{m} . \mathrm{v}\end{array}$ & \\
\hline $\mathrm{t}_{51}$ & $\begin{array}{l}\tau_{5} \text { - A principal equação utilizada para o cálculo é a } \\
\text { expressão da conservação da quantidade de } \\
\text { movimento, } \Delta \mathrm{Q}=0\end{array}$ & \\
\hline $\mathrm{t}_{61}$ & $\begin{array}{l}\tau_{6} \text { - A principal equação utilizada para o cálculo é a } \\
\text { expressão da energia cinética, } E=(1 / 2) \mathrm{m} \cdot \mathrm{v}^{2}\end{array}$ & $\theta_{4}-$ Energia Mecânica. \\
\hline
\end{tabular}

A análise do fascículo revela que nessa atividade a autonomia discente no bloco prático-técnico, especialmente no que tange às técnicas para cumprimento das tarefas $\mathrm{t}_{1}, \mathrm{t}_{21} \mathrm{e}$ $t_{22}$, está restrita a execução das regras de montagem e de programação contidas no guia da atividade.

Quanto ao bloco tecnológico-teórico, a principal teoria $[\Theta]$ identificada remete às leis de conservação, especialmente ao princípio de conservação da energia e do momento linear, necessário majoritariamente para melhor compreensão de $T_{5}$ e $T_{6}$ da atividade "colisões" e suas respectivas tecnologias $\left(\theta_{3}\right.$ e $\left.\theta_{4}\right)$.

Observa-se ainda que em $\mathrm{T}_{6}$ é solicitado o valor teórico da velocidade para que ocorra a conservação da quantidade de movimento, porém, não se faz menção direta a sistemas 
isolados e a necessária condição de que a resultante das forças externas atuantes seja nula. Isto fica, então, a cargo da Instituição [I] discutir e melhor trabalhar. Obviamente que a Instituição tem total liberdade para seguir de modo rígido ou não as orientações do fascículo, como ocorre na adoção de qualquer livro didático, podendo ampliar, reduzir ou excluir qualquer práxis ou logos que lhe convir na $\mathrm{OP}$ didática.

\subsection{3 - Atividade "Sismógrafo".}

A problematização central dessa atividade remete a utilização dos sismógrafos para registrar e medir abalos sísmicos, bem como na leitura e interpretação dos sismogramas. $\mathrm{O}$ primeiro tipo de atividade identificada (Figura 32), $\mathrm{T}_{1}$, corresponde à simulação de um abalo sísmico que deverá ser registrado pelo sismógrafo.

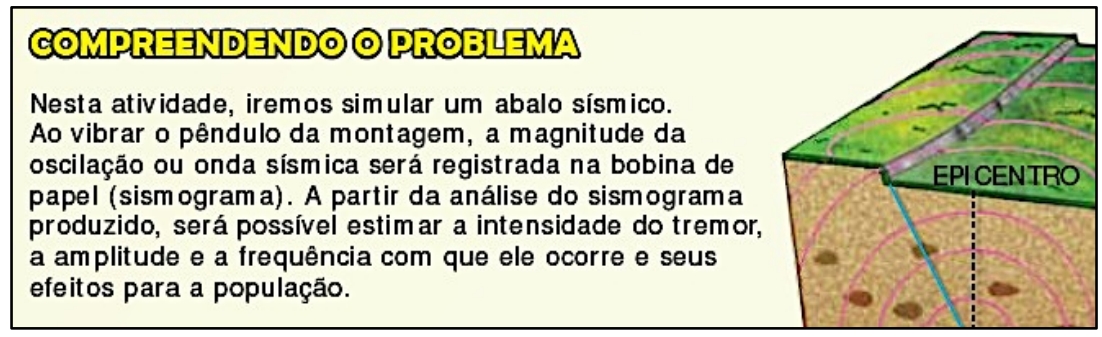

Figura 32 - Extrato do fascículo da atividade "Sismógrafo" em que se identifica o tipo de tarefa $T_{1}$.

A montagem do sismógrafo e o registro das ondas mecânicas (abalos sísmicos simulados), por meio de um sismograma, representam o segundo e o terceiro tipo de tarefa, $\mathrm{T}_{2}$ e $\mathrm{T}_{3}$, respectivamente (Figura 33).

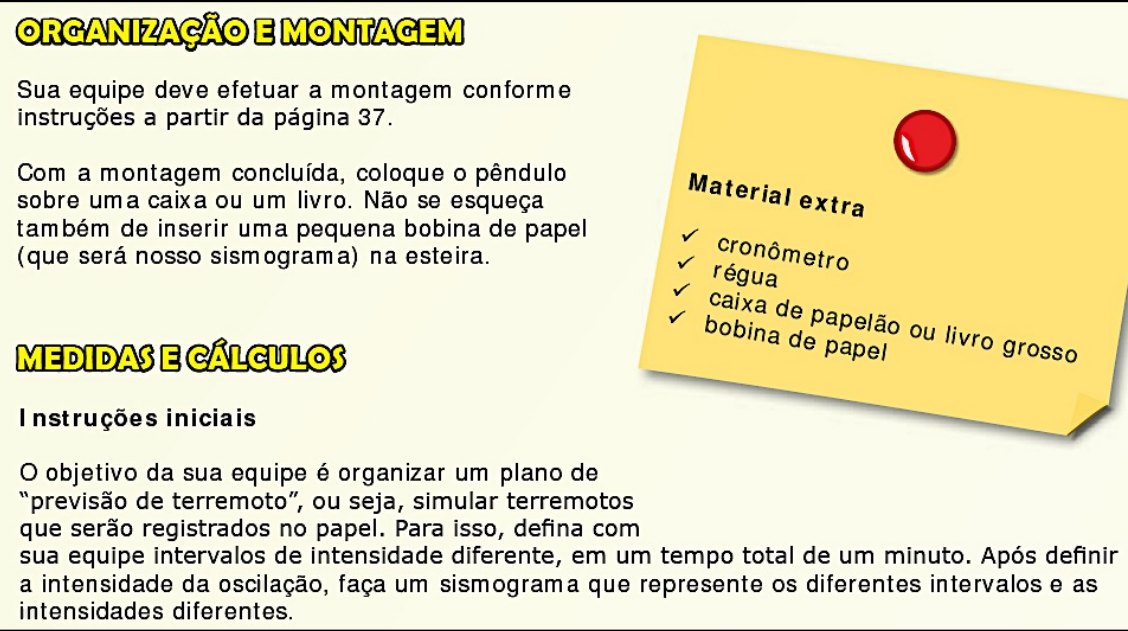

Figura 33 - Extrato do fascículo da atividade "Sismógrafo" em que se identificam os tipos de tarefa $\mathrm{T}_{2}$ e $\mathrm{T}_{3}$. 
Por sua vez, a análise do sismograma corresponde ao quarto tipo de tarefa, $\mathrm{T}_{4}$ (Figura 34). Por fim, com base nos resultados da análise do sismograma, devem-se estimar quais são os efeitos físicos produzidos pelas oscilações (que simulam um terremoto) e a frequência com que podem ocorrer, correspondendo, portanto, ao quinto tipo de tarefa, $\mathrm{T}_{5}$.

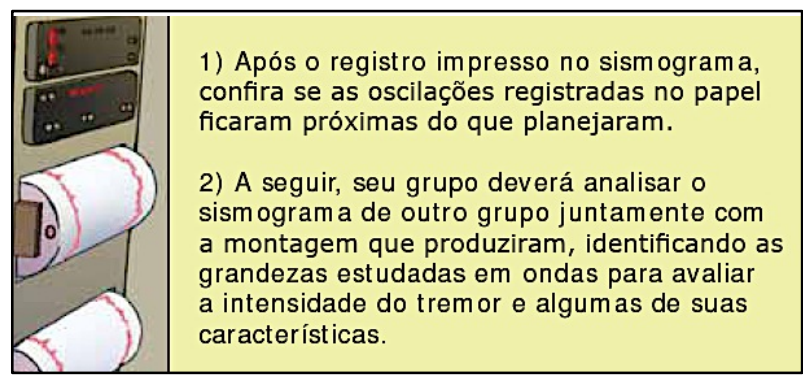

Figura 34 - Extrato do fascículo da atividade "Sismógrafo" em que se identifica o tipo de tarefa $\mathrm{T}_{4}$.

Resumimos na Tabela 10 os principais tipos de tarefa $(\mathrm{T})$ identificados na atividade "Sismógrafo" e as respectivas tarefas [t]. Em seguida, a Tabela 11 apresenta as principais técnicas e tecnologias indicadas nessa OP didática para a realização de cada tipo de tarefa.

Tabela 10 - Atividade "sismógrafo" em termos de tipos de tarefa e tarefas.

\begin{tabular}{|c|c|}
\hline Tipo de Tarefa (T) & Tarefa $(t)$ \\
\hline \multirow{2}{*}{$\begin{array}{l}\mathrm{T}_{1}-\text { Simular um abalo } \\
\text { sísmico. }\end{array}$} & $\begin{array}{l}\mathrm{t}_{11}-\text { Planejar padrões de oscilação mecânicas com diferentes } \\
\text { intensidades e intervalos de tempo. }\end{array}$ \\
\hline & $\begin{array}{l}\mathrm{t}_{12}-\text { Produzir tremores de acordo com o padrão de oscilações } \\
\text { planejado. }\end{array}$ \\
\hline $\begin{array}{l}\mathrm{T}_{2}-\text { Construir um } \\
\text { sismógrafo. }\end{array}$ & $\mathrm{t}_{21}$ - Construir um sismógrafo com base no movimento de um pêndulo. \\
\hline $\begin{array}{l}\mathrm{T}_{3}-\text { Registrar ondas } \\
\text { mecânicas. }\end{array}$ & $\begin{array}{l}\mathrm{t}_{31}-\text { Fazer um sismograma com base no padrão de oscilações } \\
\text { detectados pelo sismômetro (pêndulo). }\end{array}$ \\
\hline \multirow{5}{*}{$\begin{array}{l}\mathrm{T}_{4}-\text { Analisar um } \\
\text { sismograma. }\end{array}$} & $\mathrm{t}_{41}$ - Identificar quantos "padrões de oscilações" há no sismograma. \\
\hline & $\begin{array}{l}t_{42} \text { - Determinar qual a amplitude média das oscilações verificadas em } \\
\text { cada intervalo de tempo. }\end{array}$ \\
\hline & $\mathrm{t}_{43}$ - Determinar a duração da intensidade dos diferentes tremores. \\
\hline & $\mathrm{t}_{44}$ - Calcular a frequência aproximada das oscilações. \\
\hline & $\mathrm{t}_{45}$ - Calcular o período das oscilações em cada intervalo de tempo. \\
\hline $\begin{array}{l}\mathrm{T}_{5} \text { - Estimar os efeitos } \\
\text { físicos e frequência de } \\
\text { abalos sísmicos. }\end{array}$ & $\begin{array}{l}\mathrm{t}_{51} \text { - Com base na análise do sismograma, verificar quais os efeitos } \\
\text { físicos provocados e a frequência dos abalos sísmicos detectados pelo } \\
\text { sismógrafo. }\end{array}$ \\
\hline
\end{tabular}


Tabela 11 - Atividade "sismógrafo" em termos de técnicas e tecnologias.

\begin{tabular}{|c|c|c|}
\hline $\begin{array}{c}\text { Tarefa } \\
\text { (t) }\end{array}$ & Técnica $(\tau)$ & Tecnologias $(\theta)$ \\
\hline $\mathrm{t}_{11}$ & $\begin{array}{l}\tau_{11} \text { - No intervalo de um minuto, gera-se um padrão de } \\
\text { cinco oscilações com intensidades diferentes, variando } \\
\text { em fraca, forte, média e nula (sem oscilação). Há um } \\
\text { intervalo de no mínimo } 5 \text { e máximo } 15 \text { segundos entre } \\
\text { cada padrão de oscilação, que é definido pelo grupo. }\end{array}$ & \multirow{2}{*}{$\begin{array}{l}\theta_{1}-\text { O fascículo foca no estudo } \\
\text { de elementos da física } \\
\text { ondulatória, porém, as técnicas } \\
\text { adotadas para realizar as tarefas } \\
\mathrm{t}_{11} \text { e } \mathrm{t}_{12} \text { se apoiam nas três Leis } \\
\text { de Newton, com ênfase no } \\
\text { principio da inércia através do } \\
\text { movimento de um pêndulo para } \\
\text { detectar oscilações mecânicas. }\end{array}$} \\
\hline$t_{12}$ & $\begin{array}{c}\tau_{12} \text { - Movimentar no plano horizontal, de acordo com } \\
\text { um padrão de oscilações planejado, uma caixa ou base } \\
\text { qualquer que apoia o sismômetro (pêndulo). }\end{array}$ & \\
\hline$t_{21}$ & $\begin{array}{c}\tau_{2} \text { - Utiliza-se o kit Lego NXT Mindstorms e o manual } \\
\text { de montagem, que apresenta passo-a-passo os esquemas } \\
\text { de montagem do sismógrafo que tem como sismômetro } \\
\text { um pêndulo. }\end{array}$ & $\begin{array}{c}\theta_{2}-\text { Elementos da mecatrônica, } \\
\text { como desenho técnico } \\
\text { mecânico, cinemática e } \\
\text { elementos de máquinas } \\
\text { direcionados para } \\
\text { desenvolvimento do } \\
\text { sismógrafo com pêndulo } \\
\text { vertical. }\end{array}$ \\
\hline$t_{31}$ & $\begin{array}{c}\tau_{3} \text { - Utiliza-se um sensor de luz programado para } \\
\text { detectar o movimento do pêndulo. As informações } \\
\text { coletadas são processadas pelo NXT e registrado em } \\
\text { uma bobina de papel que corre sobre uma caneta. A } \\
\text { caneta é fixada em um braço mecânico que se } \\
\text { movimenta em função das oscilações do pêndulo } \\
\text { detectadas pelo sensor. Toda a programação é } \\
\text { desenvolvida através do Lego NXT Mindstorms } \\
\text { Software } 2.0 \text { e fornecida pelo professor, que a insere no } \\
\text { tijolo programável. }\end{array}$ & $\theta_{3}$ - Lógica de Programação. \\
\hline $\mathrm{t}_{41}$ & $\begin{array}{l}\tau_{41} \text { - Observar e contar os padrões característicos de } \\
\text { onda decorrentes de cada intensidade de oscilação } \\
\text { registrado no sismograma e um intervalo de tempo. }\end{array}$ & \multirow{5}{*}{$\begin{array}{l}\theta_{4}-\text { Elementos de física } \\
\text { ondulatória, como amplitude, } \\
\text { comprimento, período, } \\
\text { frequência e velocidade de } \\
\text { propagação de onda. }\end{array}$} \\
\hline $\mathrm{t}_{42}$ & $\begin{array}{c}\tau_{42} \text { - Medir com uma régua a amplitude das oscilações } \\
\text { para cada um dos intervalos de tempo ou padrões de } \\
\text { oscilações registrados. }\end{array}$ & \\
\hline$t_{43}$ & $\begin{array}{c}\left.\tau_{43} \text { - Calcular a velocidade da esteira ( } \boldsymbol{v}\right) \text { (considerada } \\
\text { constante) para então, com base na medida da distância } \\
(\boldsymbol{d}) \text { entre os picos (cristas) das ondas localizadas nos } \\
\text { extremos de cada padrão de oscilação, utilizar a } \\
\text { expressão } \boldsymbol{t}=\boldsymbol{d} / \boldsymbol{v} \text { para determinar a duração }(\boldsymbol{t}) \text { da } \\
\text { intensidade dos diferentes tremores. }\end{array}$ & \\
\hline $\mathrm{t}_{44}$ & \multirow{2}{*}{$\begin{array}{c}\tau_{44} \text { - Utiliza-se a expressão } \boldsymbol{f}=\mathbf{1} / \boldsymbol{T} \text {, onde } \mathbf{T} \text { é o período } \\
\text { da onda, determinado através da técnica } \tau_{43} \text {, porém, com } \\
\text { a diferença que nessa situação a distância }(\boldsymbol{d}) \text { deve ser } \\
\text { medida a partir de duas cristas consecutivas. }\end{array}$} & \\
\hline $\mathrm{t}_{45}$ & & \\
\hline $\mathrm{t}_{51}$ & $\begin{array}{l}\tau_{51} \text { - Utiliza-se uma tabela de referência para comparar } \\
\text { o valor da amplitude média obtido para cada padrão de } \\
\text { oscilação e, assim, poder estimar o efeitos causados } \\
\text { pelos tremores e a frequência com que podem ocorrer. }\end{array}$ & $\begin{array}{l}\theta_{5}-\text { O fascículo apresenta uma } \\
\text { tabela de referência que tem } \\
\text { por base a Escala Mercalli. }\end{array}$ \\
\hline
\end{tabular}


A análise do fascículo revela que essa atividade foca no estudo dos elementos da Física ondulatória $\left(\theta_{4}\right)$, que promovem as técnicas $\tau_{41}, \tau_{42}, \tau_{43}$ e $\tau_{44}$ para realizar a tarefa central da OP didática, ou seja, analisar um sismograma $\left(\mathrm{T}_{4}\right)$.

Contudo, por focar apenas na análise do sismograma, nota-se que a construção e o princípio de funcionamento do sismógrafo não são explorados de forma satisfatória nessa atividade. Essencialmente, os sismógrafos funcionam com base no princípio da inércia e possuem sismômetros formados por mecanismos diversos, como pêndulos simples, invertido e de torção, sistemas massa-mola, acelerômetros, dentre outros. Como os sismômetros estão localizados sobre a superfície da Terra, compartilham do seu movimento, e tentem a permanecer em repouso ou em movimento uniforme até que uma força resultante não nula altere seu estado, o que causará o registro do movimento do solo em que se encontra o sensor, obedecendo, assim, à lei da inércia. Além disso, podemos identificar no teorema trabalhoenergia o elemento $\Theta$ (teoria) que compõe o bloco tecnológico-teórico dessa OP didática, uma vez que o movimento do solo (nesse caso, uma caixa ou base qualquer) cede energia para o sismômetro, permitindo-lhe realizar trabalho (oscilar um pêndulo ou movimentar a massa de um sistema massa-mola, por exemplo), transferindo, desse modo, energia de um lugar para outro ou transformando uma forma de energia em outras. Ao executar a tarefa $t_{12}$, os alunos estão justamente realizando trabalho e cedendo energia para o sistema que, por sua vez, recebe essa energia e realiza trabalho ao movimentar o pêndulo da montagem desenvolvida. Porém, toda essa discussão envolvendo o bloco tecnológico-teórico não é explicitada no texto do aluno e fica a cargo da instituição (I) explorar ou não.

\subsection{4 - Atividade "Código de Barras".}

Essa é uma atividade relativamente simples, que envolve basicamente três tipos de tarefas (Figura 35). O primeiro e principal tipo de tarefa, $\mathbf{T}_{\mathbf{1}}$, é a confecção de um código de barras a partir de uma tabela-verdade de quatro bits (tabela com o código de referência). $\mathrm{O}$ objetivo desse código é armazenar informações sobre sentido e direção de movimento de um veículo robótico numa área delimitada por um mapa. Uma vez criado o código de barras, é preciso desenvolver um mecanismo capaz de "ler" a informação armazenada e transmiti-la para o veículo, configurando-se esta decodificação o segundo tipo de tarefa, $\mathbf{T}_{2}$. Por fim, no terceiro tipo de tarefa, $\mathbf{T}_{3}$, o veículo deve executar as informações decodificadas, movimentando-se de acordo com o comando inserido no código de barras. 


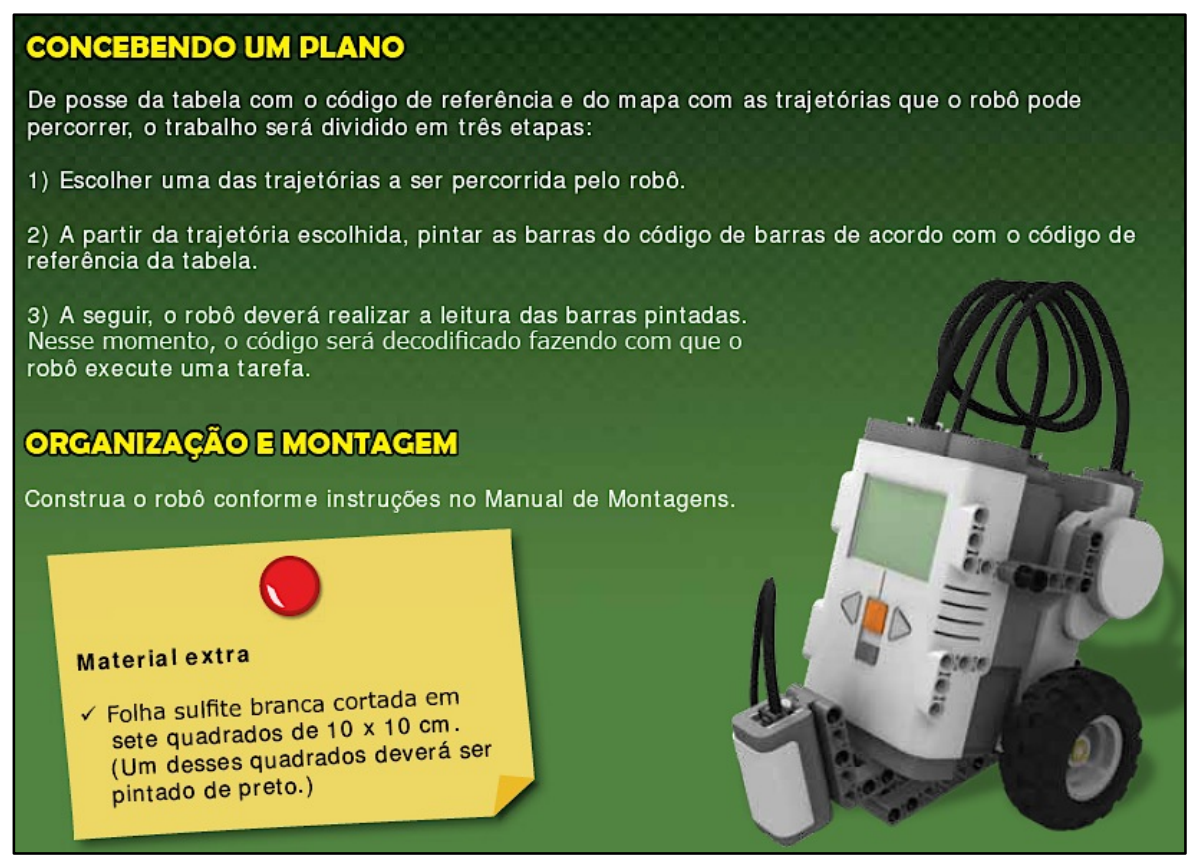

Figura 35 - Extrato do fascículo da atividade "Código de barras" em que se identificam $\mathrm{T}_{1}, \mathrm{~T}_{2}$ e $\mathrm{T}_{3}$.

Cada tipo de tarefa se decompõe em diferentes tarefas, porém, correlacionadas e que colaboram para investigar o problema central da atividade (Como os códigos de barras conseguem armazenar tantas informações sobre os produtos?). Para realizar $\mathrm{T}_{2}$, por exemplo, é necessário construir um leitor óptico, que por sua vez, demanda estratégias e materiais próprios. Resumimos na Tabela 12 as principais tarefas [t] decorrentes de $T_{1}, T_{2}$ e $T_{3}$, bem como as principais técnicas e tecnologias (Tabela 13) identificadas nessa OP didática para a realização de cada tipo de tarefa.

Tabela 12 - Atividade "código de barras" em termos de tipos de tarefa e tarefas.

\begin{tabular}{|c|l|}
\hline Tipo de Tarefa (T) & \multicolumn{1}{c|}{ Tarefa (t) } \\
\hline \multirow{2}{*}{$\begin{array}{c}\mathrm{T}_{1}-\text { Criar um código de } \\
\text { barras. }\end{array}$} & $\mathrm{t}_{11}-$ Determinar e codificar a trajetória a ser percorrida pelo robô. \\
\cline { 2 - 2 } & $\begin{array}{l}\mathrm{t}_{12}-\text { Pintar as listas verticais escuras do código de barras em função do } \\
\text { código binário gerado. }\end{array}$ \\
\hline \multirow{2}{*}{$\begin{array}{c}\mathrm{T}_{2}-\text { Decodificar um } \\
\text { código de barras. }\end{array}$} & $\begin{array}{l}\mathrm{t}_{21}-\text { Construir um leitor óptico capaz de identificar as lista claras e } \\
\text { escuras do código de barras. }\end{array}$ \\
\cline { 2 - 2 } $\begin{array}{c}\mathrm{t}_{22}-\text { Programar o leitor óptico para ser capaz de "ler" o código de barras } \\
\text { desenvolvido. }\end{array}$ \\
\hline $\begin{array}{c}\text { informações } \\
\text { decodificadas. }\end{array}$ & $\begin{array}{l}\mathrm{t}_{31}-\text { Chegar com o robô ao quadrado preto colocado no ponto A do mapa } \\
\text { de acordo com as trajetórias decodificadas. }\end{array}$ \\
\cline { 2 - 2 } & $\begin{array}{l}\mathrm{t}_{32}-\text { Chegar com o robô ao quadrado preto colocado no ponto B do mapa } \\
\text { de acordo com as trajetórias decodificadas. }\end{array}$ \\
\hline
\end{tabular}


Tabela 13 - Atividade "código de barras" em termos de técnicas e tecnologias.

\begin{tabular}{|c|c|c|}
\hline Tarefa (t) & Técnica $(\tau)$ & Tecnologias $(\theta)$ \\
\hline $\mathrm{t}_{11}$ & \multirow{2}{*}{$\begin{array}{l}\tau_{1} \text { - Confecção de um código binário de listas } \\
\text { verticais igualmente espaçadas e de mesma } \\
\text { largura a partir de uma tabela-verdade de } 4 \text { bits. } \\
\text { Cada conjunto de bits representa um sentido de } \\
\text { movimento e equivale a um deslocamento de } 10 \\
\text { cm do veículo robô. }\end{array}$} & \multirow[b]{2}{*}{$\begin{array}{c}\theta_{1}-\text { Sistemas binários e } \\
\text { Portas Lógicas. }\end{array}$} \\
\hline $\mathrm{t}_{12}$ & & \\
\hline $\mathrm{t}_{21}$ & $\begin{array}{c}\tau_{2}-\text { Utiliza-se o kit Lego NXT Mindstorms e o } \\
\text { manual de montagem, que apresenta passo-a-passo } \\
\text { os esquemas de montagem do veículo robótico } \\
\text { acoplado ao leitor óptico, constituído de um sensor } \\
\text { de luz. }\end{array}$ & $\begin{array}{c}\theta_{2}-\text { Elementos da } \\
\text { mecatrônica, como } \\
\text { desenho técnico } \\
\text { mecânico, cinemática e } \\
\text { elementos de máquinas } \\
\text { direcionados para } \\
\text { desenvolvimento do robô } \\
\text { com sensor óptico } \\
\text { digital. }\end{array}$ \\
\hline$t_{22}$ & \multirow{3}{*}{$\begin{array}{l}\tau_{3}-\text { Quando o sensor de luz passar sobre o código } \\
\text { de barras, da esquerda para a direita, a leitura de } \\
\text { uma faixa clara é processada pelo NXT e } \\
\text { convertida no número } 0 \text { e a de uma faixa escura } \\
\text { no número } 1 \text { (números binários). Cada conjunto } \\
\text { de } 4 \text { bits é então decodificado e executado pelo } \\
\text { robô, o qual desloca-se } 10 \mathrm{~cm} \text { na direção e } \\
\text { sentido determinado pelo código de barras. Toda } \\
\text { a programação é desenvolvida através do Lego } \\
\text { NXT Mindstorms Software } 2.0 \text { e fornecida pelo } \\
\text { professor, que a insere no tijolo programável. }\end{array}$} & \multirow{3}{*}{$\begin{array}{l}\theta_{3}-\text { Lógica de } \\
\text { Programação. }\end{array}$} \\
\hline $\mathrm{t}_{31}$ & & \\
\hline$t_{32}$ & & \\
\hline
\end{tabular}

Constatou-se que o foco dessa atividade é a tecnologia $\theta_{1}$ (que compreende a realização das tarefas $t_{11}$ e $t_{12}$ por meio da técnica $\tau_{1}$ ) uma vez que $\theta_{2}$ e $\theta_{3}$ não são discutidas explicitamente no fascículo para efetuar as técnicas $\tau_{2}$ e $\tau_{3}$. O bloco tecnológico-teórico referente ao tipo de tarefa $\mathrm{T}_{1}$ pode conter, ainda, enquanto teoria $\Theta$, a Álgebra de Boole aplicada a circuitos digitais, uma vez que apresenta funções que tem uma ou mais variáveis de entrada e fornecem um único resultado que depende apenas dos valores dessas variáveis. Contudo, como essa teoria não faz parte da estrutura curricular da educação básica, a atividade "código de barras" limita-se aos elementos tecnológicos $\theta_{1}, \theta_{2}$ e $\theta_{3}$. 


\subsection{5 - Considerações gerais.}

Em todas as atividades analisadas ("Empilhadeiras", "Colisões", "Sismógrafo" e "Código de barras"), observou-se que o bloco-tecnológico apresenta mais de um elemento $\theta$ (tecnologia), o qual possibilita melhor compreender e justificar as técnicas adotadas para efetivar determinadas tarefas. Isso pode auxiliar a modelização dos saberes disciplinares necessários para melhor compreender e/ou solucionar a situação apresentada na problematização inicial de cada atividade didática.

Quanto ao bloco prático-técnico, é interessante notar que a investigação da problematização inicial pode demandar uma quantidade significativa de tarefas e tipos de tarefas, como é o caso identificado na atividade Colisões, com um total de 5 (cinco) tipos de tarefas e 8 (oito) tarefas principais. Além disso, a técnica necessária para realização de algumas tarefas pode ser de complexidade elevada, como a programação utilizada nas atividades Sismógrafo e Código de Barras, cabendo a Instituição (I) de um modo geral (com exceção do aluno) executar essa técnica. Esses dois aspectos, quantidade elevada de tarefas e técnicas complexas, podem influenciar negativamente na investigação do problema central, especialmente por demandar maior tempo para compreendê-las, desenvolvê-las e/ou executálas.

Em todas as atividades investigadas constataram-se correlações diretas e consistentes entre elementos praxeológicos do bloco prático-técnico com o tecnológico-teórico como, por exemplo, entre $\tau_{3}$ (técnica adotada para elevar e transportar a carga) e $\theta_{3}$ (princípio da gangorra) na atividade Empilhadeiras, entre $\tau_{4}$ (expressão $Q=m . v$ ) e $\theta_{3}$ (Leis de Newton) na atividade Colisões, entre $\mathrm{T}_{4}$ (análise do sismograma) e $\theta_{4}$ (elementos de Física ondulatória) na atividade Sismógrafo e entre $\mathrm{T}_{1}$ (criar um código de barras) e $\theta_{1}$ (sistemas binários e portas lógicas) na atividade Código de Barras.

Contudo, em alguns casos o bloco tecnológico-teórico não se encontra plenamente desenvolvido, nestes o elemento $\Theta$ (teoria) foi ignorado ou suprimido. Conforme observado na atividade Empilhadeiras, por exemplo, a explicação que permeia a tecnologia $\theta_{3}$ (Princípio da alavanca), poderia ser complementada ou ampliada com base na lei de conservação da energia (teoria, $\Theta$ ), o que não se verificou. Nesse mesmo aspecto, a atividade Sismógrafo não discute o princípio da inércia (tecnologia, $\theta$ ) e o teorema trabalho-energia $(\Theta)$, ambos correspondem ao bloco tecnológico-teórico que auxilia na compreensão do princípio físico de funcionamento da maioria dos sismógrafos e sua correlação com os abalos sísmicos. 


\section{2 - Contextualização no ensino de física: análise de atividades por Verossimilhança Praxeológica.}

Os resultados provenientes da análise praxeológica efetuada no item anterior seguem, de maneira geral, os mesmos padrões das demais pesquisas encontradas na literatura, especialmente das que trabalham com livros didáticos (TEIXEIRA \& SILVA, 2013; ZANARDI, PEREIRA \& KNEUBIL, 2012; NOGUEIRA, 2008), expondo os principais constituintes praxeológicos identificados na OP didática e como eles se correlacionam. Entretanto, buscamos também demonstrar aqui a possibilidade de se avaliar o quanto atividades ou sequências didáticas que façam uso desses instrumentos (RE) "dialogam" (ou não) com a prática social de referência, uma dada realidade que fundamenta a problematização e que se busca contextualizar. Notamos que isso pode ser feito avaliando também o nível de Verossimilhança Praxeológica (VP), seja por interseção ou por correspondência, em termos de tipos de tarefa, técnicas, tecnologias e teorias conforme discutido anteriormente.

Para auxiliar a análise na perspectiva da VP, desenvolvemos um Mapa Conceitual (MC) para cada OP didática investigada anteriormente e outro para suas respectivas OP de referência, totalizando em 8 (oito) Mapas Conceituais.

Primeiramente, desenvolve-se o MC da OP de referência a partir de estudos diversos, desde a leitura de artigos e textos especializados, até a consulta e entrevista com técnicos e profissionais do setor, destacando os principais elementos praxeológicos. Na sequência, o MC da OP didática é desenvolvido com base no estudo do fascículo do aluno, destacando também os principais tipos de tarefas, as técnicas, tecnologias e teorias identificados na atividade (explícitos ou não).

O mapa conceitual de cada OP didática é então contrastado com o mapa da sua respectiva OP de referência, de modo a se verificar ocorrências de elementos praxeológicos comuns nas duas OPs, revelando, portanto, aspectos de VP. Para isso, cada mapa é desenvolvido com base numa questão focal similar entre a OP de referência e didática. É importante ressaltar que não existem mapas conceituais com design, termos de ligação e conceitos idênticos, desenvolvidos para responder uma mesma questão focal. É possível elaborar diferentes mapas, alguns com mais, outros com menos informações sobre a questão levantada. Isso vai depender principalmente do grau de compreensão do sujeito que elaborou o mapa e do nível de investigação realizado, além da quantidade de conceitos e termos de 
ligação empregados. Contudo, tomamos o devido cuidado para que o mapa conceitual desenvolvido não excluísse os principais tipos de tarefas, técnicas e tecnologias presentes/identificados tanto na OP de referência quanto na OP didática.

A seguir, apresentamos os principais resultados alcançados decorrentes desse processo de análise. A identificação numérica dos tipos de tarefa, das técnicas, tecnologias e teorias não apresentam relação direta com a identificação utilizada na análise anterior.

\subsection{1 - Atividade "Empilhadeiras"}

Conforme discutido no capítulo anterior, essa atividade explora uma situação cotidiana de transportes de cargas a partir de empilhadeiras elétricas de pequeno porte, comum em supermercados atacadistas, situação essa que se configura como a OP de referência contextualizada pela OP didática.

$\mathrm{O}$ MC da OP de referência (Figura 36) foi desenvolvido com base em informações provenientes de manuais de operação, normas de segurança e manual do fabricante, além dos principais conceitos físicos identificados nessa ação (implícitos ou explícitos). A questão focal é: quais são os principais componentes e princípios físicos que regem o funcionamento de uma empilhadeira elétrica e como se dá o transporte de cargas?

Por sua vez, o mapa conceitual indicado pela Figura 37 diz respeito a OP didática, e apresenta a seguinte questão focal: como a atividade didática (Empilhadeiras) está estruturada e é desenvolvida em relação a montagem e aos principais conceitos físicos?

Interessante notar que, tanto na OP da prática social de referência quanto na OP didática, ainda que em escala reduzida, percebe-se a necessidade de um ponto de apoio (fulcro) e de um contra peso (composto pelos motores e baterias) posicionado a uma determinada distância do fulcro (localizado no eixo que perfaz as rodas dianteiras) para o correto funcionamento da empilhadeira e transporte seguro da carga. 


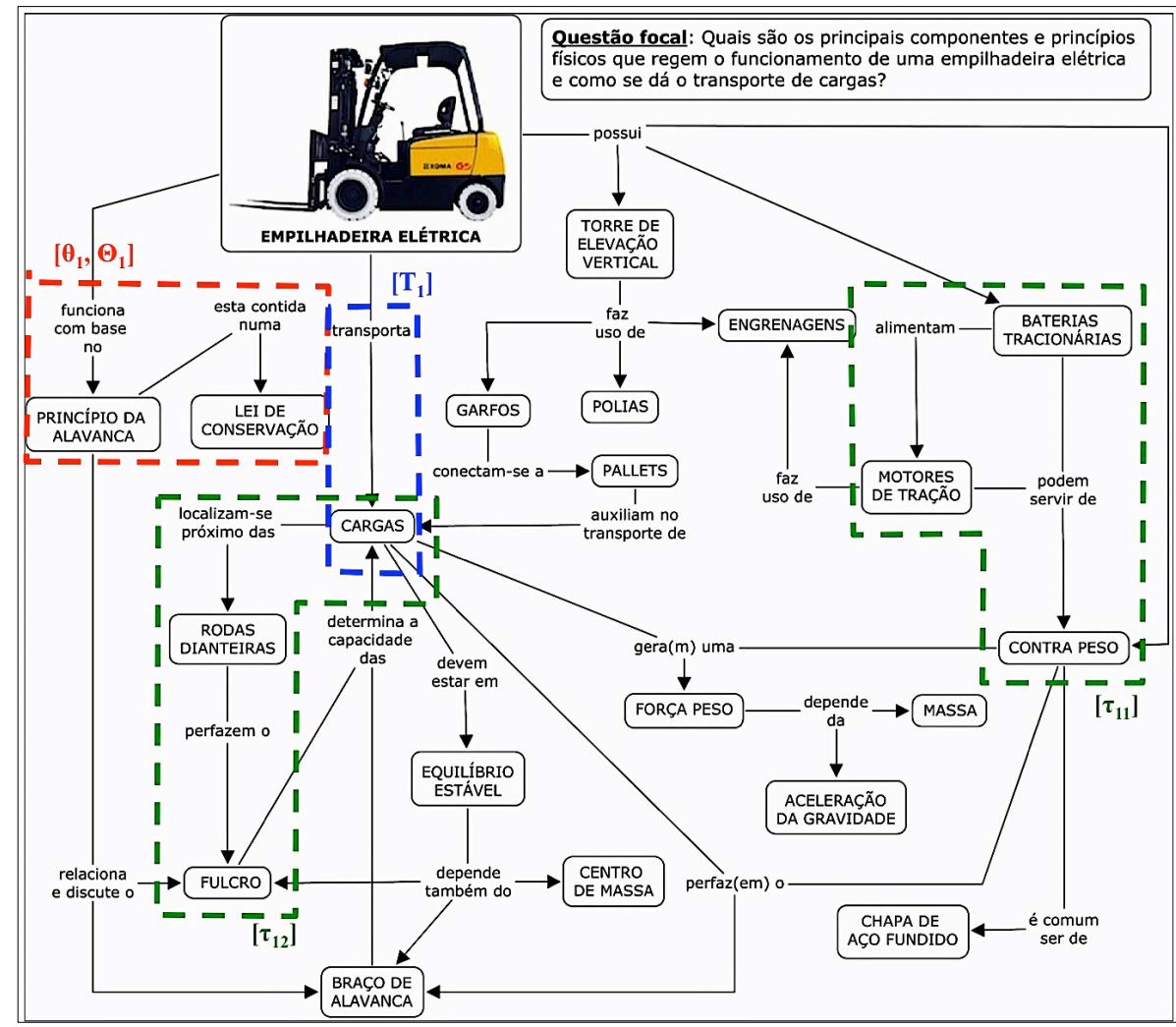

Figura 36 - Mapa conceitual referente aos principais aspectos estruturais e conceituais identificados na OP da prática social de referência - "transporte de cargas via empilhadeiras".

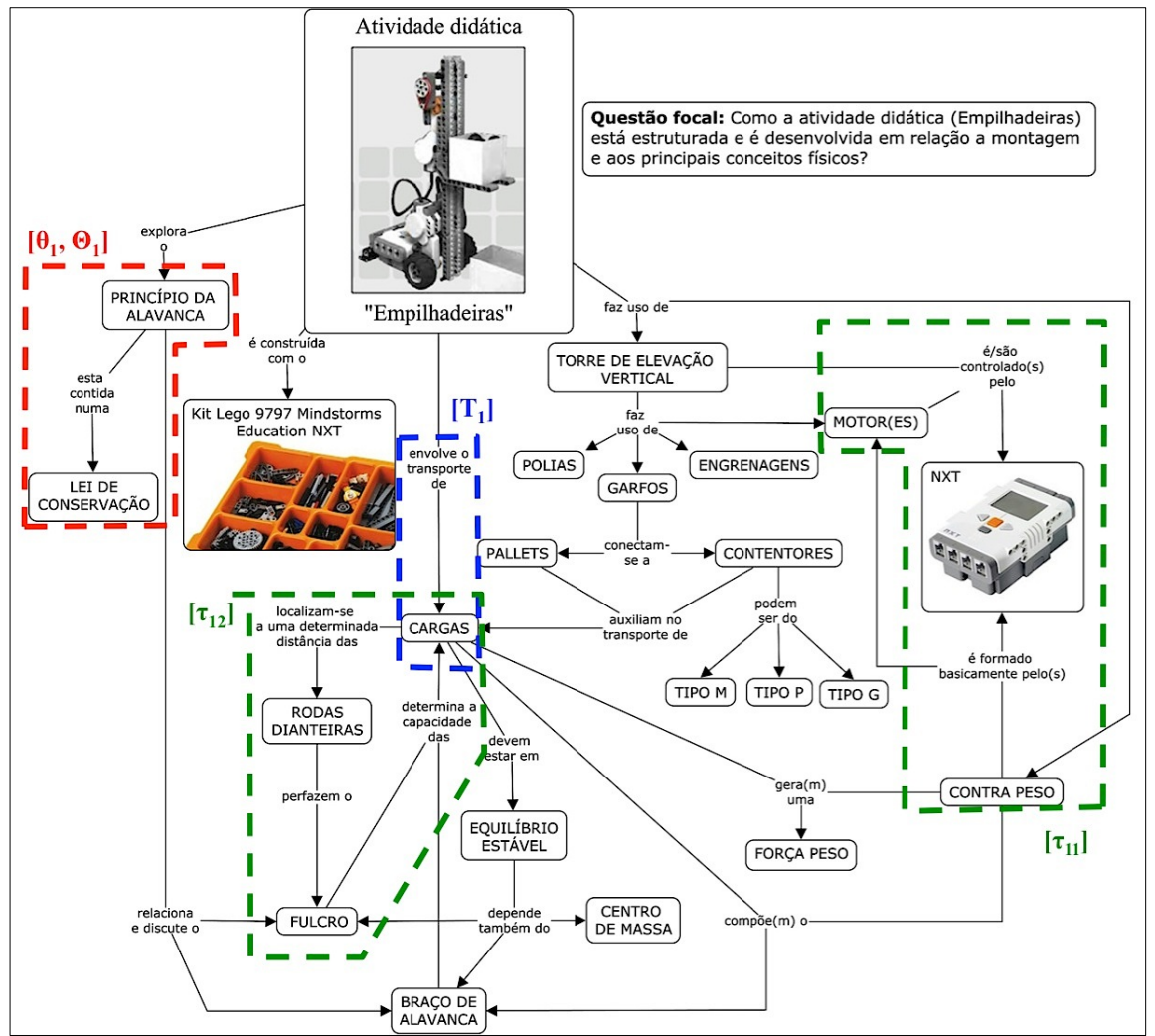

Figura 37 - Mapa conceitual referente aos principais aspectos estruturais e conceituais identificados na OP didática - atividade "Empilhadeiras". 
Podemos identificar a existência de uma mesma técnica $\left(\tau_{12}\right.$, destaque em verde) para realizar o mesmo tipo de tarefa $\left(\mathrm{T}_{1}\right.$, destaque em azul) (transporte de cargas, porém, em escala reduzida). A compreensão dessa técnica, a tecnologia $\left(\theta_{1}\right)$, envolve o entendimento do conceito Torque por meio do princípio da alavanca. Identifica-se então uma VP por interseção, com tipo de tarefa, técnica e tecnologia comum nas duas OPs. Por outro lado, apesar de apresentar um mesmo tipo de tarefa (transportar cargas), a OP didática contém ainda tarefas que apresentam apenas uma similaridade com a OP de referência como, por exemplo, o próprio desenvolvimento e construção da empilhadeira fazendo uso do kit de robótica, correspondendo, portanto, ao que denominamos de VP por correspondência.

Apesar da existência de uma VP por interseção, ela não é explorada na OP didática e fica subtendida no fascículo. Nota-se que em ambos os MCs o conceito "Lei de Conservação", Teoria $\left[\Theta_{1}\right]$, está contido no conceito "Princípio da alavanca", tecnologia $\left[\theta_{1}\right]$, formando o bloco tecnológico-teórico $\left[\theta_{1}, \Theta_{1}\right]$ (destaque em vermelho). Assim, dependendo da intenção didática do professor ao explorar esse contexto via a robótica educacional, é possível discutir ainda leis de conservação, ou seja, tratar da teoria que possibilita melhor compreender e justificar a tecnologia (princípio da alavanca). Isso pode ser feito ao se discutir que: ao mesmo tempo em que o contrapeso da empilhadeira realiza trabalho (seja na prática social de referência ou na atividade didática), aplicando uma força peso sobre uma das extremidades do braço de alavanca responsável pela potência, a outra extremidade realiza trabalho sobre a carga, mantendo a empilhadeira em equilíbrio estável. Entretanto, na OP didática isso não é realizado (ao menos, não explicitamente). Constata-se que a atividade "Empilhadeiras" não avança em termos de aprofundamento na discussão do bloco tecnológico-teórico, deixando de fora o elemento $\Theta$ (teoria), nesse caso, Leis de Conservação.

Mesmo não havendo um aprofundamento na discussão referente à teoria $\Theta$, percebe-se que a contextualização não reduziu os aspectos sociais da educação científica ao espaço físico proximal dos alunos, na verdade, ela apresentou elementos conceituais e técnicos que foram explorados na atividade didática dentro de uma Verossimilhança Praxeológica. Quanto maior for a quantidade desses elementos praxeológicos similares entre o contexto e a atividade didática, maior será a verossimilhança.

A robótica educacional, nesse caso, favoreceu o controle e alteração de variáveis para discutir o princípio da alavanca (presente nas duas OP) como, por exemplo, alterar a distância entre o centro de massa da carga e o fulcro e aumentar a capacidade de carga a ser 
transportada. Interessante notar que, desse modo, a OP didática pode ter um caráter mais investigativo e problematizador. Diferente da OP de referência, o desafio proposto passa a ser em escala reduzida, constitui-se agora em transportar de modo seguro, em equilíbrio estável, caixas de diferentes dimensões, contendo bolinhas de gude.

\subsection{2 - Atividade "Colisões".}

Adotamos o mesmo procedimento anterior, ou seja, desenvolvimento inicial de um MC das duas OP. No caso da atividade "Colisões”, são muito escassas as informações sobre a OP de referência em que se apoia a OP didática, uma vez que se trata de um campeonato específico, no qual há colisões propositais de veículos.

$\mathrm{O}$ MC da OP de referência (Figura 38) foi desenvolvido basicamente via informações provenientes de filmagens dos campeonatos de Shock Car (disponibilizados no Youtube) e do próprio fascículo da atividade, além de um estudo dos principais conceitos físicos identificados nessa ação (implícitos ou explícitos). A questão focal é: O que é um campeonato de Shock Car e quais são os principais conceitos físicos que regem as colisões entre os veículos dessa competição?

Já o mapa conceitual representado pela Figura 39 diz respeito à OP didática, cuja questão focal é: Como a atividade didática (Colisões) está estruturada e é desenvolvida em relação à montagem e aos principais conceitos físicos? Para sua confecção apoiamos o estudo majoritariamente nas informações contidas no fascículo dessa atividade.

Assim como na atividade "Empilhadeiras", esses dois mapas também apontam para alguns elementos praxeológicos comuns as duas OP, apontando para aspectos de verossimilhança. Entretanto, nota-se que nessa OP didática exige-se condições de um cenário extremamente controlado, com pistas planas e niveladas, velocidades constantes e choque frontal o mais alinhado possível. Tais condições não se identificam na correspondente OP de referência. 


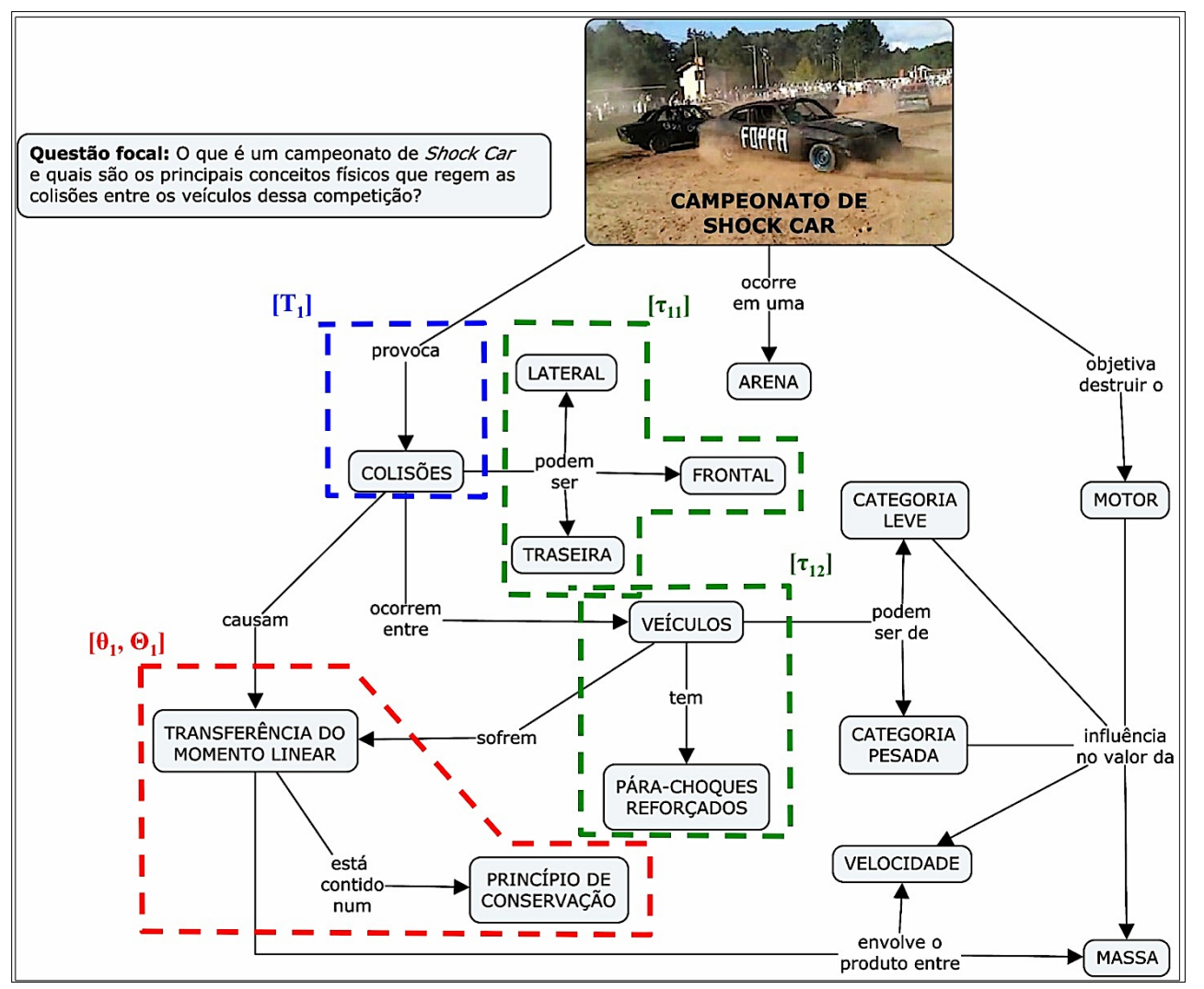

Figura 38 - Mapa conceitual referente aos principais aspectos estruturais e conceituais identificados na OP da prática social de referência - "Colisões em campeonatos de Shok Car".

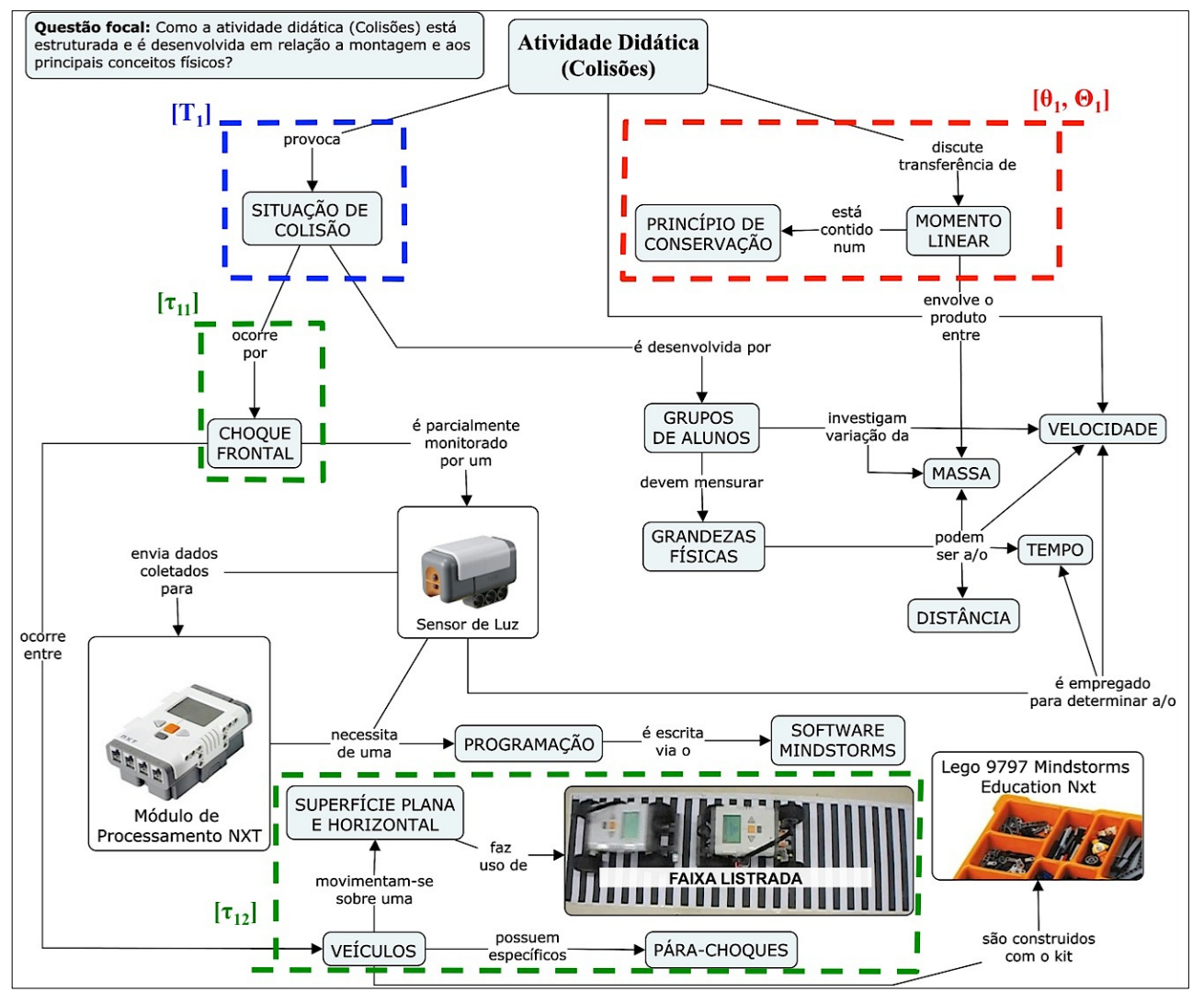

Figura 39 - Mapa conceitual referente aos principais aspectos estruturais e conceituais identificados na OP didática - atividade "Colisões". 
Nota-se que, tanto na OP de referência (Figura 38) quanto na OP didática (Figura 39), há a necessidade de um alinhamento dos veículos (de tal modo a aumentar a "eficiência" da batida), destes possuírem determinada massa e velocidade no momento da colisão, além da "adequação" dos para-choques. Tais ações remetem ao bloco prático-técnico, porém, todas as técnicas aplicadas na OP didática para efetuar a colisão entre os veículos não correspondem diretamente a OP de referência uma vez que se adotam materiais e configurações diferentes, há apenas uma correspondência entre ambas, ou seja, uma VP por correspondência. Além disso, nota-se que a OP didática apresenta outras técnicas, associadas à tarefa de determinar a quantidade de movimento de cada veículo, imediatamente antes e após a colisão.

A melhor compreensão do fenômeno físico presente numa situação de colisão entre os veículos (seja na OP didática ou de referência) envolve necessariamente o estudo da conservação do momento linear e do princípio de conservação da energia mecânica (Teoria, $\Theta)$. Desse modo, pode existir a ocorrência de uma VP por interseção, pois temos a presença de um mesmo bloco tecnológico-teórico (leis de conservação) contido nas duas OP (didática e de referência), tornando a contextualização mais rica e pertinente para o ensino de Física. Infelizmente, de acordo com a análise praxeológica que efetuamos dessa atividade, constatouse foco demasiado no bloco prático-técnico. Isso fica mais evidente ao se analisar os momentos didáticos.

\subsection{3 - Atividade "Sismógrafo".}

Nessa atividade, observa-se que a OP didática explora apenas uma única opção de montagem para o sismógrafo e a onda gerada para provocar o sismo é apenas longitudinal na direção horizontal. Porém, quando comparada com a OP de referência, constata-se que os sismógrafos possuem sismômetros de diferentes tipos e as ondas sísmicas provocadas pelo movimento do solo podem ser longitudinais e também transversais. Contudo, um dos principais tipos de tarefa presente nas duas OPs, detectar e registrar o movimento da superfície ou solo, permanece o mesmo. Por meio dos mapas conceituais da OP de referência e da OP didática é possível identificar essas e outras correlações de forma mais clara.

Para guiar o desenvolvimento do MC da OP de referência (Figura 40), optou-se pela seguinte questão focal: o que é um sismógrafo e quais são os principais componentes e princípios físicos que regem seu funcionamento? A principal fonte de consulta para gerar os conceitos e termos de ligação desse mapa foram os textos disponíveis no site do Instituto de 
Astronomia, Geofisica e Ciências Atmosféricas da USP (IAG) referentes a fenômenos e métodos geofísicos ${ }^{27}$, além de informações contidas no próprio texto da atividade.

Com relação ao desenvolvimento do MC da OP didática (Figura 41), apoiamos o estudo majoritariamente nas informações contidas no fascículo dessa atividade, e sua questão focal é: como a atividade didática (Sismógrafo) está estruturada e é desenvolvida em relação a montagem e aos principais conceitos fisicos?

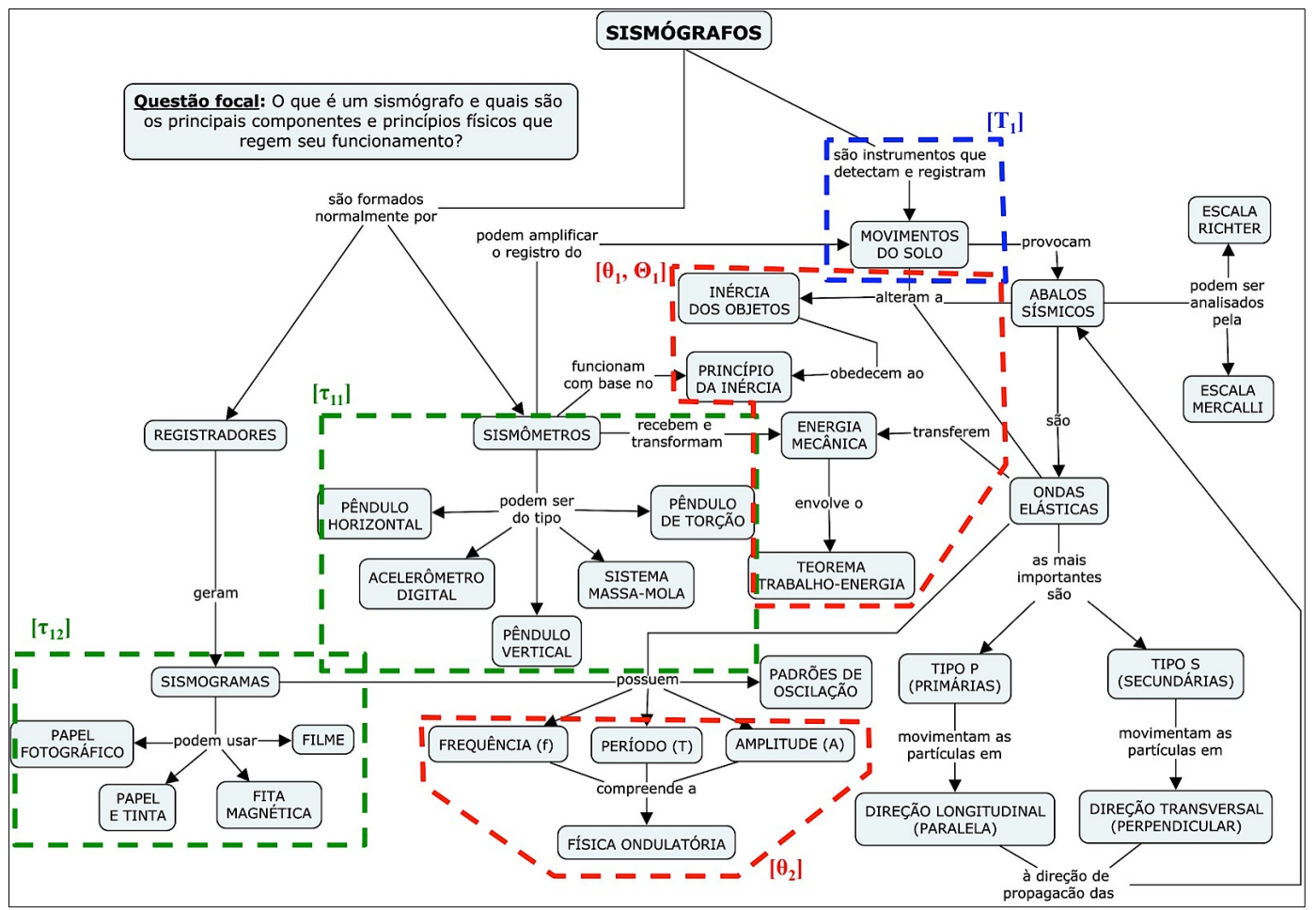

Figura 40 - Mapa conceitual referente aos principais aspectos estruturais e conceituais identificados na OP de referência - "Sismógrafo".

Por meio do MC da OP didática, nota-se que o tipo de tarefa $\left[\mathrm{T}_{1}\right]$ (em azul) não corresponde, de fato, à detecção e registro de um abalo sísmico como ocorre na OP de referência. O sismógrafo da OP didática não é utilizado para detectar vibrações decorrentes de abalos sísmicos reais, pois esses abalos são apenas simulados através de vibrações mecânicas provocadas pelos próprios alunos $\left[\tau_{1}\right]$. Nesse caso, apesar dos tremores de Terra e das vibrações provocadas pelos alunos configurarem oscilações mecânicas, podemos afirmar que se trata de um VP por correspondência em termos do tipo de tarefa $T_{1}$ entre a OP didática e a OP de referência.

\footnotetext{
${ }^{27}$ Site do IAG, sessão de Geofísica. Disponível em http://www.iag.usp.br/siae98/geofisica/geofisica.htm Acesso em 12 de Julho de 2014. 


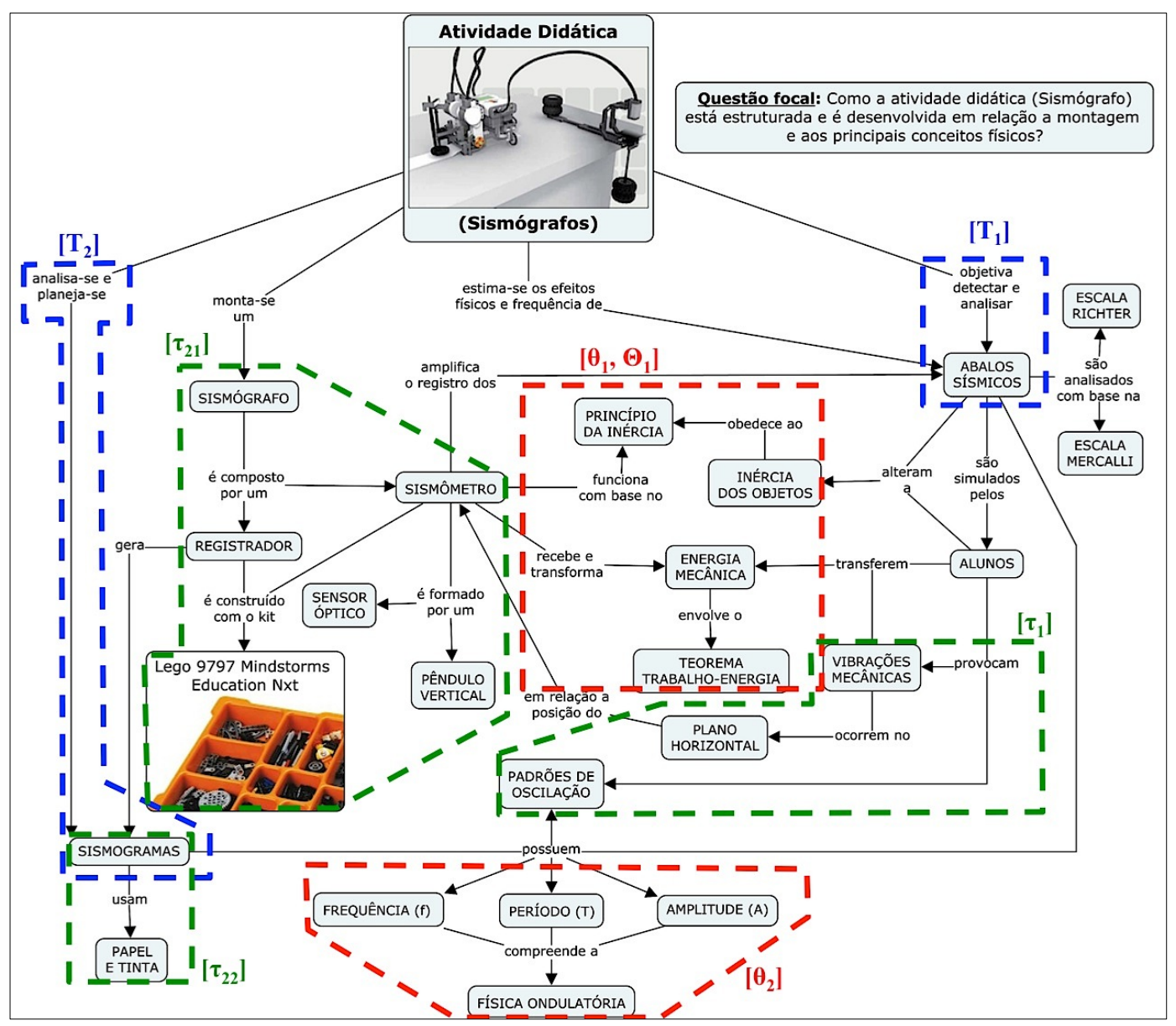

Figura 41 - Mapa conceitual referente aos principais aspectos estruturais e conceituais identificados na OP didática - "Sismógrafo".

Constata-se VP por interseção referente ao bloco tecnológico-teórico $\left[\theta_{1}, \Theta_{1}\right]$ e a tecnologia $\left(\theta_{2}\right)$ (destaque em vermelho) identificados nas duas OP de acordo com os mapas conceituais (Figura 40 e Figura 41). Independente da natureza das vibrações mecânicas detectadas e registradas pelo sismógrafo, elas transferem energia para o sistema ao realizar trabalho (Teorema Trabalho-Energia), alterando o estado de inércia de alguns mecanismos que compõem o sismômetro, como pêndulos e sistemas massa-mola. Por sua vez, o sismômetro recebe e transforma parte dessa energia em outras formas como, por exemplo, em elétrica, ao transmitir informações para o registrador gerar o sismograma. Contudo, essa discussão, que denota a existência de uma organização praxeológica local, com tarefas (provocar vibrações mecânicas para simular abalos sísmicos) e técnicas (realizar trabalho para provocar vibrações mecânicas no plano horizontal em relação à posição do sismômetro, alterando a inércia dos objetos) justificadas e compreendidas por um mesmo bloco tecnológico-teórico (Princípio da Inércia e Teorema Trabalho-Energia) não é explorada e fica subtendida no fascículo, a cargo da Instituição desenvolver em função da sua intenção 
didática.

Com base no sismograma, é possível estudar vários elementos de um onda, como período de oscilação, amplitude e frequência, conceitos esses presentes na Física ondulatória e que compõem o elemento $\theta_{2}$ tanto na OP didática quanto na $\mathrm{OP}$ de referência, conforme observado nos respectivos mapas conceituais. Essa tecnologia $\left[\theta_{2}\right]$, comum nas duas OP e que aponta para uma VP por interseção, é amplamente discutida e explorada na atividade através da análise e do próprio desenvolvimento dos sismogramas.

Por fim, as técnicas $\tau_{21}$ e $\tau_{22}$ (em verde) contidas no desenvolvimento do sismógrafo da OP didática apresentam ainda uma VP por correspondência com as da OP de referência $\left(\tau_{11}\right.$ e $\left.\tau_{12}\right)$. Apesar de utilizar um pêndulo vertical como sismômetro e um registrador para gerar o sismograma, o sismógrafo da OP didática não é capaz de realizar todas as tarefas da OP de referência, uma vez que os movimentos do solo são detectados no sentido horizontal (direção Leste-Oeste e Norte-Sul) e vertical, captando ondas longitudinais e perpendiculares à direção de propagação dos abalos sísmicos.

De um modo geral, essa atividade apresenta potencial didático-pedagógico significativo para contextualizar a tarefa de detectar, registrar e analisar abalos sísmicos, mais precisamente, vibrações mecânicas provenientes do movimento do solo ou da superfície em que se encontra o sismômetro.

\subsection{4 - Atividade “Código de Barras”.}

Das quatro atividades analisadas, essa é a que mais apresenta relação direta com o cotidiano do aluno, uma vez que os códigos de barras estão presentes nas embalagens de praticamente todos os produtos que consumimos. Essa tecnologia (no sentido amplo do termo) é amplamente utilizada na indústria, comércio em geral, bancos, bibliotecas, hospitais, bancos de sangue, correios, transportes, controles de acesso, etc.

Para desenvolvimento do mapa conceitual da OP de referência (Figura 42), foram consultadas matérias jornalísticas, como a edição do Globo Ciência sobre o código de barras $^{28}$, artigos técnicos, em especial da Microsoft sobre desenvolvimento de códigos de

\footnotetext{
${ }^{28}$ Globo Ciência - 07/06/2014. Disponível em: http://globotv.globo.com/rede-globo/globo-ciencia/v/globo-ciencia07062014-codigo-de-barras-integra/3394225/ Acesso em 14 de Julho de 2014. 
barras $^{29}$, e artigos diversos de divulgação científica, em especial a edição n. 180 da Revista Ciência Hoje $e^{30}$, além de informações contidas no próprio texto da atividade. A questão focal do MC da OP de referência é: como funcionam e são utilizados os códigos de barras?

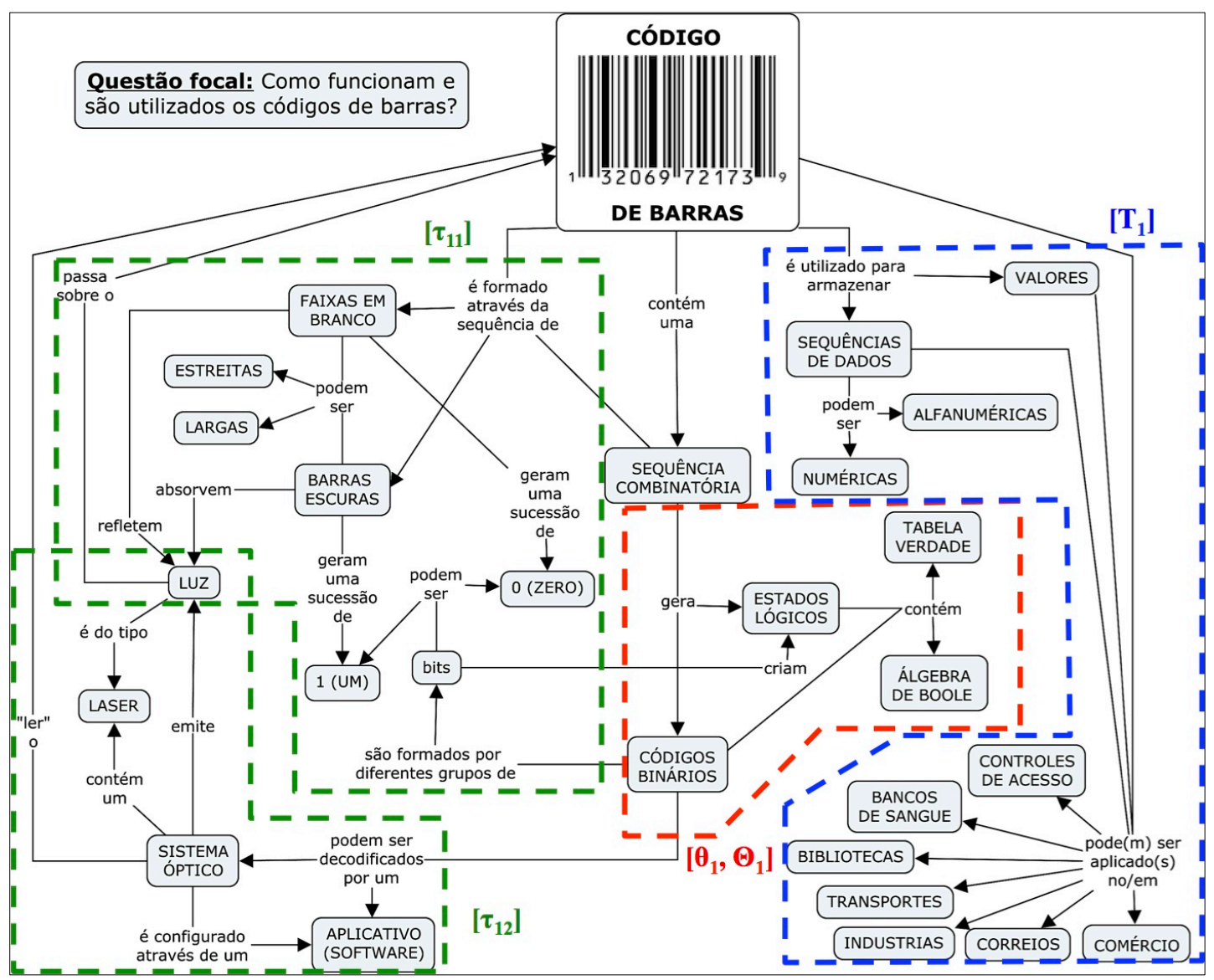

Figura 42 - Mapa conceitual referente aos principais aspectos estruturais e conceituais identificados na OP de referência - "Código de barras".

Com relação ao desenvolvimento do $\mathrm{MC}$ da $\mathrm{OP}$ didática (Figura 43), apoiamos o estudo majoritariamente nas informações contidas no fascículo dessa atividade, e sua questão focal é: como a atividade didática (Código de barras) está estruturada e é desenvolvida em relação à montagem e aos principais conceitos fisicos?

\footnotetext{
${ }^{29}$ Texto "Código de barras sem mistérios". Disponível em http://msdn.microsoft.com/pt-br/library/cc580676.aspx Acesso em 14 de Julho de 2014.

${ }^{30}$ Matéria "Como funciona o código de barras". Disponível em

http://chc.cienciahoje.uol.com.br/multimidia/revistas/reduzidas/180/?revista=180\#/8/zoomed Acesso em 14 de Julho de 2014.
} 


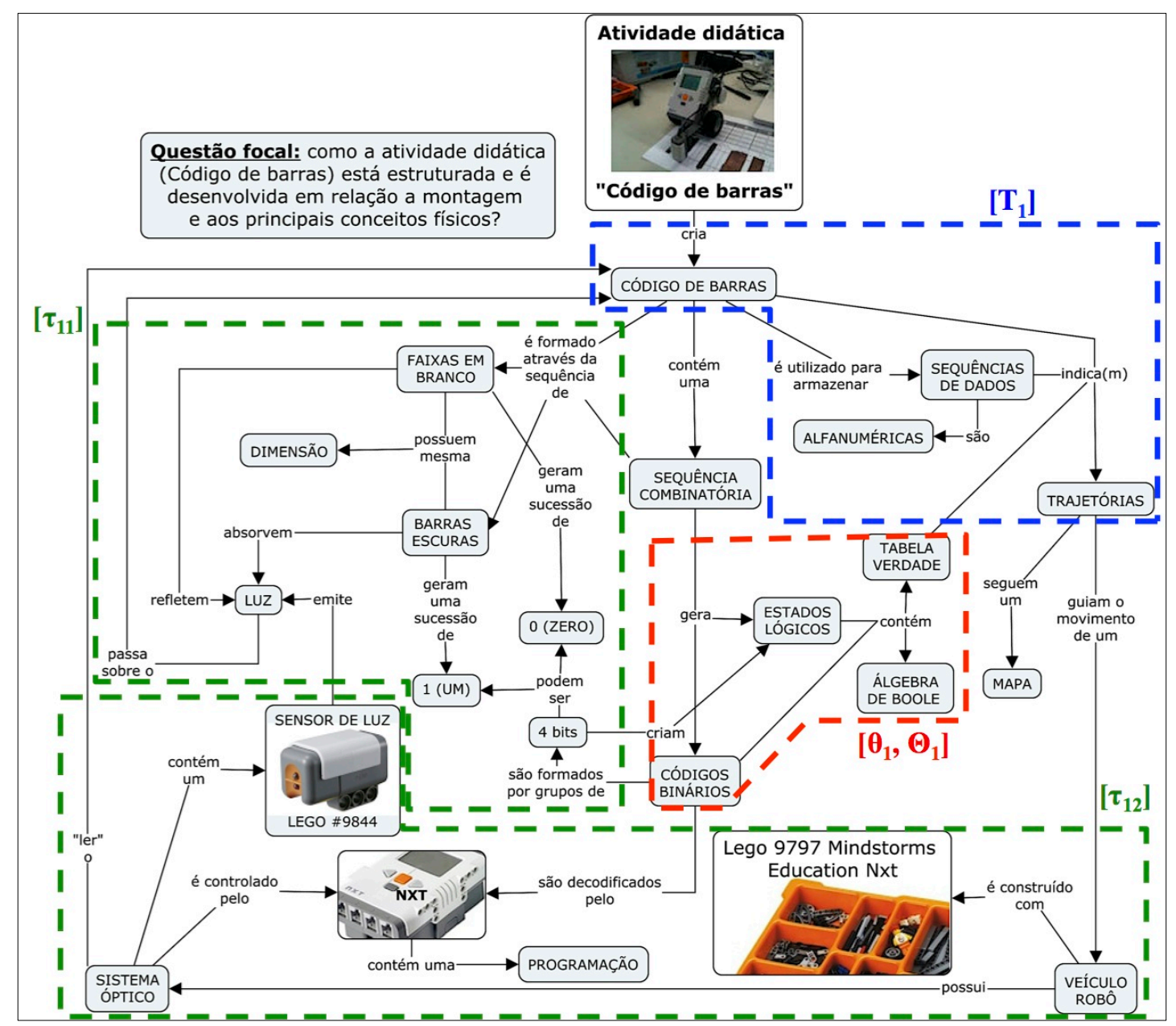

Figura 43 - Mapa conceitual referente aos principais aspectos estruturais e conceituais identificados na OP didática - "Código de barras".

Interessante notar que, fundamentalmente, a construção do código de barras e, posteriormente, sua "leitura" seguem o mesmo padrão tanto na OP didática quanto na OP de referência. A principal técnica adotada $\tau_{11}$ (em verde) para criar o código de barras remete a sequência combinatória de barras escuras e brancas, as quais formam uma sucessão de 0 e 1 que compõem o código binário. Entretanto, como as barras utilizadas na OP didática diferem da OP de referência em relação à dimensão das listas e grupos de bits, podemos afirmar que se trata de uma VP por correspondência em termos da técnica $\tau_{11}$.

O sistema óptico utilizado na OP didática e desenvolvido por meio de kits de robótica educacional, não é capaz de "ler" um código de barras da OP de referência com grande confiabilidade, especialmente porque esse código possui listas pretas e brancas muito próximas uma da outra e de pequena largura. Além disso, a OP de referência geralmente utiliza um sistema óptico que é composto de uma fonte de luz laser, diferente da OP de didática que utiliza um LED receptor e emissor de luz difusa através do sensor de luz. 
Portanto, a técnica $\tau_{12}$ adotada para "ler" o código de barras na OP didática, apesar do esquema geral ser o mesmo, apresenta também uma VP por correspondência com a OP de referência.

Por fim, como os códigos de barras podem ser aplicados em uma infinidade de setores, armazenando informações das mais diversas como, por exemplo, indicar a sequência de movimentos que uma determinada máquina deverá executar na montagem ou estocagem de um produto, pode-se afirmar que há uma VP por interseção entre as duas OPs com relação ao tipo de tarefa $\mathrm{T}_{1}$. O mesmo tipo de Verossimilhança Praxeológica é identificado entre as duas OPs quanto ao bloco tecnológico-teórico $\left[\theta_{1}, \Theta_{1}\right]$, uma vez que os sistemas binários gerados pela sequência combinatória de barras escuras e claras, que compõem o código de barras tanto da OP didática quanto da OP de referência (independente da dimensão e quantidade de bits), geram estados lógicos que compreendem tabelas-verdade e álgebras de Boole. Contudo, álgebra Booleana não é mencionada na atividade didática, apesar da atividade discutir estados lógicos e construir tabelas-verdade.

\subsection{5 - Considerações gerais.}

A partir do contraste entre os mapas conceituais das atividades didáticas e de suas respectivas práticas sociais de referência, constatou-se que as OPs didáticas não reduziram os aspectos sociais da educação científica apenas ao espaço físico proximal dos alunos. Isso se deve principalmente aos indícios de VP por interseção e por correspondência entre elementos do bloco prático-técnico e tecnológico-teórico das duas OPs, apontando para múltiplas vertentes de ação que não reduzem a contextualização a uma mera ilustração de uma dada realidade, sem fins didático-pedagógicos mais profundos.

Aspectos de VP por interseção foram identificados em sua maioria por meio de elementos do bloco tecnológico-teórico comum entre a OP didática e de referência como, por exemplo, na atividade "Empilhadeiras", entre os elementos $\theta_{1}$ (Torque ou Princípio da gangorra) e $\Theta_{1}$ (Lei de conservação da energia), e na atividade "Código de barras", entre as tecnologias código binário e tabela-verdade e a teoria álgebra de Boole.

Já os aspectos de VP por correspondência foram identificados em sua maioria por meio de elementos do bloco prático-técnico comum entre a OP didática e a de referência como, por exemplo, na atividade "Sismógrafo", entre o Tipo de tarefa $\mathrm{T}_{1}$ (detectar e registrar abalos sísmicos), e na atividade "Colisões", entre as técnicas $\tau_{11}$ e $\tau_{12}$ adotadas para provocar 
a colisão entre os veículos.

As análises desenvolvidas até aqui remetem a um aspecto estrutural, seja da OP didática ou da OP de referência, revelando aspectos estáticos da contextualização em termos dos elementos praxeológicos. Passamos agora para a análise dos momentos didáticos, a qual possibilita revelar a dinâmica entre as duas OPs e investigar a relação do indivíduo com diferentes objetos da OP didática e da OP de referência no processo de contextualização. Para isso, aplicamos as atividades "Empilhadeiras" e "Colisões" para os alunos do primeiro ano do Ensino Médio do Colégio Modelo Luís Eduardo Magalhães.

\section{3 - Análise dos momentos didáticos: a relação do indivíduo com os objetos no processo de contextualização.}

\subsection{1 - Atividade "Empilhadeiras".}

Essa atividade foi aplicada duas vezes, primeiro para alunos do $1^{\circ}$ ano "A" (total de 10 alunos voluntários participantes, distribuídos em três grupos, dois com três integrantes e um com quatro) e depois para alunos do $1^{\circ}$ ano "B" (total de 6 alunos voluntários participantes, distribuídos proporcionalmente em dois grupos) do ensino médio do Colégio Modelo Luís Eduardo Magalhães em atividade extracurricular.

Na primeira aplicação, os alunos fizeram a montagem completa da empilhadeira, ou seja, partiram do zero e, seguindo o manual de montagem e sob orientações do professor, construíram a empilhadeira utilizando as peças fornecidas pelo kit. Já na segunda aplicação, a empilhadeira foi pré-montada, ação essa que diminuiu consideravelmente o tempo de montagem por parte dos alunos no decorrer da aula.

Todas as aplicações foram filmadas e analisadas utilizando o software Videograph, obedecendo a categorização apresentada anteriormente, gerando, desse modo, os gráficos a seguir para a atividade “empilhadeiras” (Figura 44 e Figura 45). 


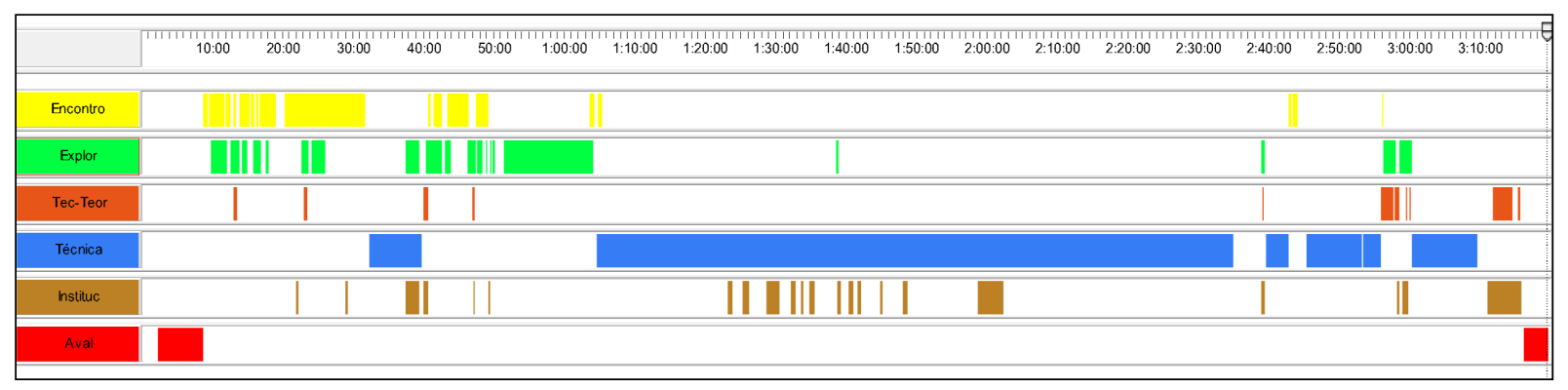

Figura 44 - Análise dos momentos didáticos: atividade "Empilhadeiras" - 10 ano "A", primeira aplicação.

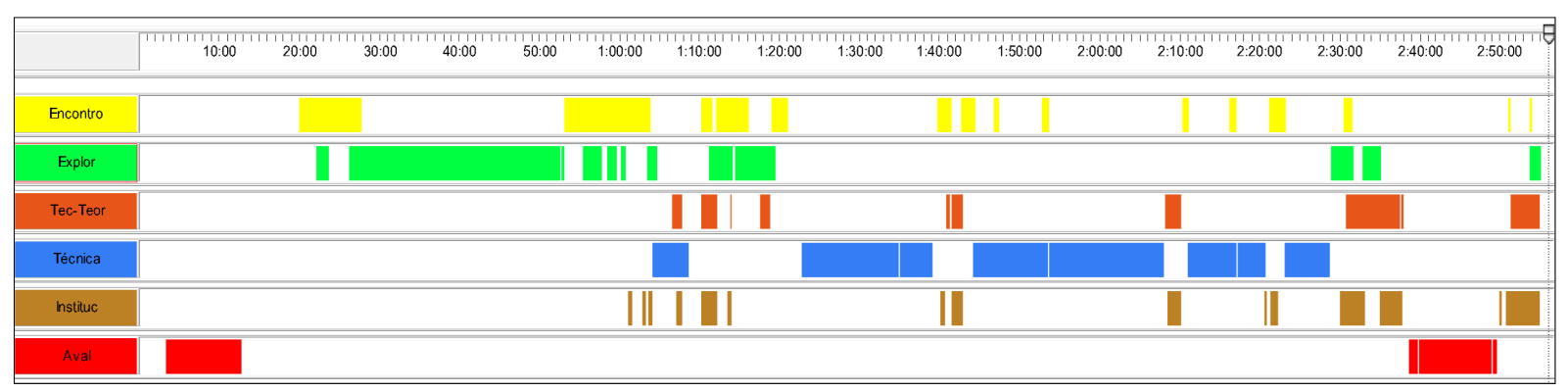

Figura 45 - Análise dos momentos didáticos: atividade "Empilhadeiras" - 10 ano "B”, segunda aplicação.

O momento exploratório e o do primeiro encontro se entrelaçam constantemente, principalmente quando o problema central e contexto são apresentados pela primeira vez. De um modo geral, constatamos que nesses momentos o professor questiona os alunos sobre determinadas situações, chamando atenção, por exemplo, para algumas possibilidades de técnicas para se resolver um determinado problema e/ou as grandezas físicas relevantes da OP de referência em jogo. Nesse período, identifica-se na fala do professor e dos alunos referências a outros cenários e situações, outras OP. Desse modo, o processo de contextualização inicia-se com apontamentos para possíveis correlações entre a OP de referência e a OP didática e/ou entre duas OP de referência como, por exemplo, correlações entre uma brincadeira de gangorra e o transporte de carga por uma empilhadeira. Percebe-se que, nesse momento do processo de estudo e de contextualização, o aluno manipula inicialmente (de modo verbalizado ou experimental) objetos da OP de referência (nesse caso, a gangorra e o transporte de cargas por uma empilhadeira). Tais objetos podem ser conceitos físicos, como impulso, força e equilíbrio, ou então tratar de propriedades materiais, como massa, distribuição, volume, etc. Os extratos a seguir com diálogos entre o professor e os alunos podem servir de exemplo para ilustrar esse ponto, a saber ${ }^{31}$ :

31 P - fala do professor, A - fala do aluno. 
P - Qual seria a situação mais adequada pra eu brincar... para a brincadeira da gangorra funcionar?

$\mathrm{A}_{1}-E u$, com o peso maior, no meu caso, para baixo, e o outro...

$\mathrm{P}-$ Eu tenho que ter duas pessoas com massas diferentes?

$\mathrm{A}_{1}-\ldots$ não, pera ai.

$\mathrm{A}_{2}-$ Não, posições diferentes, não é não?!

$\mathrm{P}$ - Mas posições você tá falando em que? Em relação...

$\mathrm{P}$ - ... se você colocar, por exemplo, a gangorra ...

$\mathrm{A}_{2}$ - Porque não é nem toda posição que a gangorra vai ficar um pra baixo e outro pra cima.

$\mathrm{A}_{3}-$ Oh, eu acredito que pode até ser diferente, mas eu acho que o que vai dá certo é o impulso que cada um vai dar em relação aos pés.

$\mathrm{P}-$ Então, oh...

$\mathrm{A}_{3}$ - Acho que, em relação a massa ... o corpo, o peso, acho que isso tem alguma diferença, mas acho que vai fazer diferença no início é o impulso que eles vão fazer.

$\mathrm{P}$ - ... que a pessoa vai dar o impulso.

$\mathrm{A}_{1}-\dot{E} \ldots$

$\mathrm{P}$ - Existiria uma situação mais adequada para a brincadeira ser mais interessante ou, por exemplo, como você falou: "Ah, massa... massas diferentes não, é... não vão intervir.". Né? "Eu vou brincar de qualquer jeito na gangorra, mas com as massas diferentes.".

$\mathrm{A}_{1}$ - Mas se uma pessoa muito gorda fica de um lado...

[risos e tumulto, vários falam ao mesmo tempo]

$\mathrm{P}$ - Então, para eu ter uma brincadeirazinha, é ..., uma brincadeira mais eficiente ali [gangorra], eu teria que ter, como ele falou lá... as massas podem ser diferentes?

$\mathrm{A}_{1}-\ldots$ são diferente, mas pouca.

$\mathrm{P}$ - Um diferença pequena, certo?

(00:09:41 à 00:11:50). $1^{\circ}$ ano "A"

P - Então, olha bem. É ... quando vocês brincavam lá de gangorra, né? O que vocês podem remeter a esse conhecimento?

$\mathrm{A}_{1}$ - Como assim?

$\mathrm{P}-\dot{E}$ de qualquer forma que você brincava ali?

$\mathrm{A}_{1}-$ Não! Tem que ter duas pessoas, uma de cada lado.

$\mathrm{P}$ - Então, olha bem. Não dá pra você brincar sozinho...

$\mathrm{A}_{1}-$ Sozinho, é $\ldots$

$\mathrm{P}$ - ...tem que ser em dupla.

$\mathrm{A}_{2}-$ Se não, não tem graça.

$\mathrm{A}_{3}-$ E se for uma pessoa mais pesada que você, você não sobe.

$\mathrm{A}_{1}-E_{\text {. }}$.

$\mathrm{A}_{3}-\mathrm{Ou}$, você não desce, sub você vai, agora descer não vai.

$\mathrm{P}$ - Então tem essa condição também...

$\mathrm{A}_{2}-$ Do peso, é...

$\mathrm{P}$ - ... certo. É... além de você ter mais de uma pessoa pra trabalhar, pra brincar, você tem que levar em consideração também...

[...]

$\mathrm{P}$ - Você acha que tem alguma relação dessa gangorra com a empilhadeira? Porque assim, tem gente que não conhece direito essa empilhadeira.

$\mathrm{A}_{1}-$ Eu acho que não. Acho que não.

$\mathrm{A}_{3}-$ Tem! Porque se botar muito peso na empilhadeira ela capota, né? Eu já vi capotar uma vez já. 
$\mathrm{A}_{4}-$ Ah é...

$\mathrm{P}-$ Então você já conhece...

$\mathrm{A}_{3}-$ Ai tem que ser o mesmo peso.

$\mathrm{P}$ - ... uma empilhadeira.

$\mathrm{A}_{3}-$ Tem o peso, se colocar além do peso ela vai...

$\mathrm{A}_{4}-$ Ela vai tombar, é...

$\mathrm{A}_{3}-\dot{E} \ldots$

(00:21:18 à 00:23:09). $1^{\circ}$ ano "B".

$\mathrm{P}-$ Se você tivesse um sobrinho pequeno ...

$\mathrm{A}_{1}-\dot{E}$ diferente!

$\mathrm{P}$ - Isso... então, ele tem uma massa menor que vocês, mas você gostaria de brincar com ele na gangorra, como é que você brincaria com ele?

[Vários alunos falam ao mesmo tempo]

$\mathrm{A}_{2}$ - Ele tinha que descer e subir... descer e subir.

$\mathrm{A}_{1}-$ Eu ia baixando ele...

[risos]

$\mathrm{A}_{3}-O u$ então ficaria mais na frente.

$\mathrm{P}$ - Então, eu poderia fazer o seguinte. Como você comentou, oh, É... tem duas formas: Eu mesmo ficaria fazendo o movimento, por que eu tenho uma massa muito maior, ou simplesmente eu poderia deslocar minha posição, né? Bom, vamos lá! Mas o que isso tem haver com a empilhadeira?

(00:40:40 à 00:41:20). $1^{\circ}$ ano "A"

Constatamos nas duas aplicações dois instantes bem demarcados e exclusivos (não há sobreposição com os demais momentos) referente ao momento exploratório (faixa verde). $\mathrm{O}$ primeiro localiza-se entre os instantes 00:51:15 e 01:04:17 ( $1^{\circ}$ ano A, Figura 44) e o segundo entre 00:27:48 e 00:52:58 ( $1^{\circ}$ ano B, Figura 45). Esses dois instantes referem-se à exploração do material didático por parte do aluno, ou melhor, seu livre contato com o kit de robótica. Trata-se de um tipo de "quebrar o gelo" no contato com novos recursos didáticos e não há um compromisso direto com a OP de referência em foco no processo de contextualização tratado na OP didática. Nesses momentos, os grupos foram convidados a desenvolverem livremente um veículo com as peças e materiais disponíveis, sem intervenção alguma do professor e sem técnicas pré-determinadas por manuais de montagem.

Em outro instante, verificou-se um longo período dedicado para o momento de trabalho da técnica na primeira aplicação ( $1^{\circ}$ ano "A"). Nessa aplicação, o primeiro extrato referente à Técnica, em azul e entre os tempos de 00:32:14 e 00:39:44, refere-se a construção de um diagrama de forças atuantes na carga a ser transportada por uma empilhadeira, já o segundo extrato, entre os tempos 01:05:15 e 02:34:00 (praticamente uma hora e meia de duração), remete a construção completa da empilhadeira propriamente dita, fazendo uso do kit de robótica e orientado pelo manual de montagem (Figura 46a) e pelo professor. A 
montagem da empilhadeira pelos grupos do $1^{\circ}$ ano "A" partiu do zero, ou seja, com todas as peças separadas individualmente e armazenadas por categorias numa bandeja, Figura 46b.

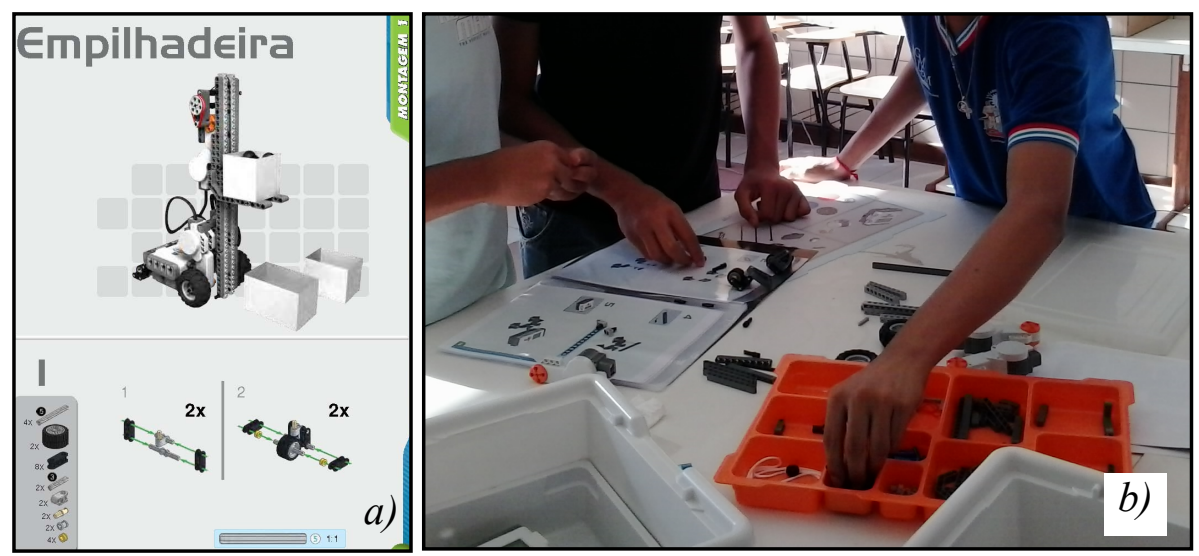

Figura 46 - a) Procedimento inicial apresentado pelo manual de montagem. b) Estudantes selecionando e coletando peças para montagem de acordo com o manual.

Dentro do processo de contextualização, esse momento de trabalho da técnica, relacionado à montagem da empilhadeira na OP didática, aponta para uma VP por correspondência, uma vez que a empilhadeira construída apresenta similaridades físicas com a empilhadeira da OP de referência, porém, em tamanho reduzido e desenvolvida com técnicas e materiais diferentes.

Curiosamente, de um modo geral, os grupos com maioria ou totalidade de meninos terminavam esse momento de trabalho com a técnica referente às montagens (seja guiado pelo manual de montagem ou não) em menor tempo que os grupos com maioria ou totalidade de meninas. Eles demonstraram uma habilidade prática-técnica mais "eficiente" que o sexo oposto quando em contato com kits de robótica educacional no desenvolvimento de alguma montagem, promovendo estruturas físicas mais complexas (quando livres para criar) e/ou em menor tempo (quando guiados pelo manual de montagem). Isso se verificou independente de ser seu primeiro contato com o kit de robótica.

Os demais momentos identificados de trabalho da técnica permeiam, por exemplo, tarefas como análise e pesagem da carga máxima (Figura 47a) e seu transporte, de modo seguro e estável, pela empilhadeira (Figura 47b). 


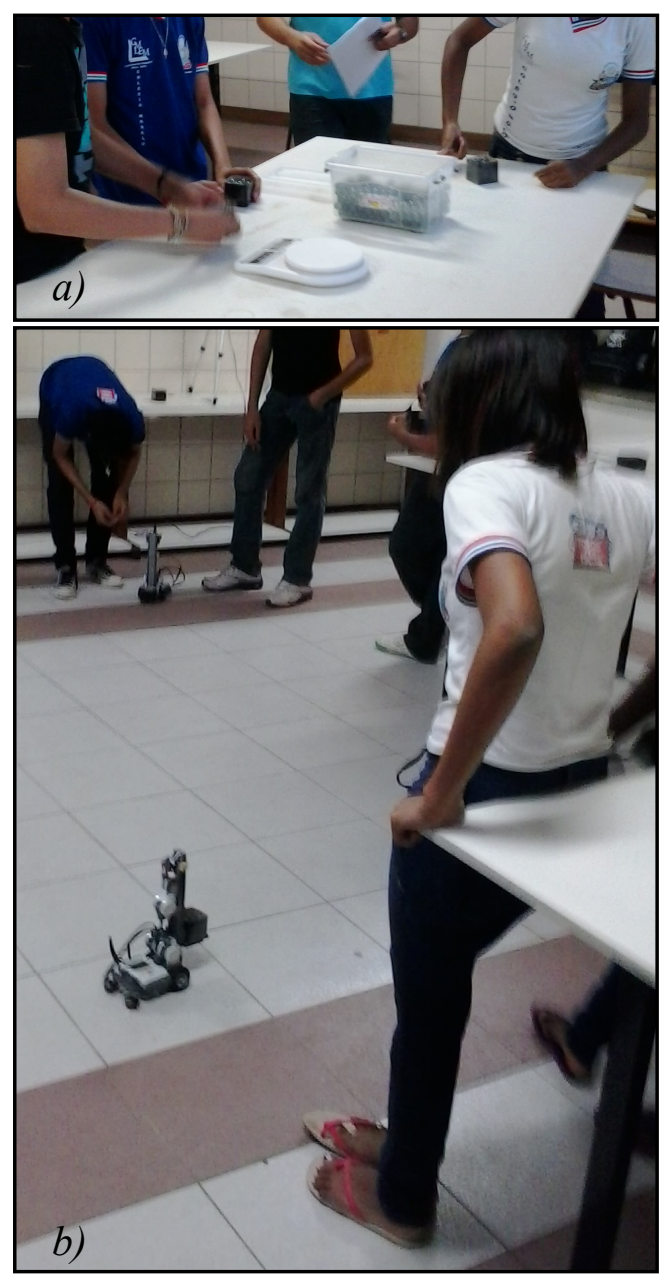

Figura 47 - a) Pesagem da carga. b) Transporte da carga.

O tempo de trabalho da técnica teve uma redução considerável na segunda aplicação ( $1^{\circ}$ ano "B"), isso ocorreu, principalmente, porque se optou por entregar a "empilhadeira" prémontada (Figura 48) aos estudantes.

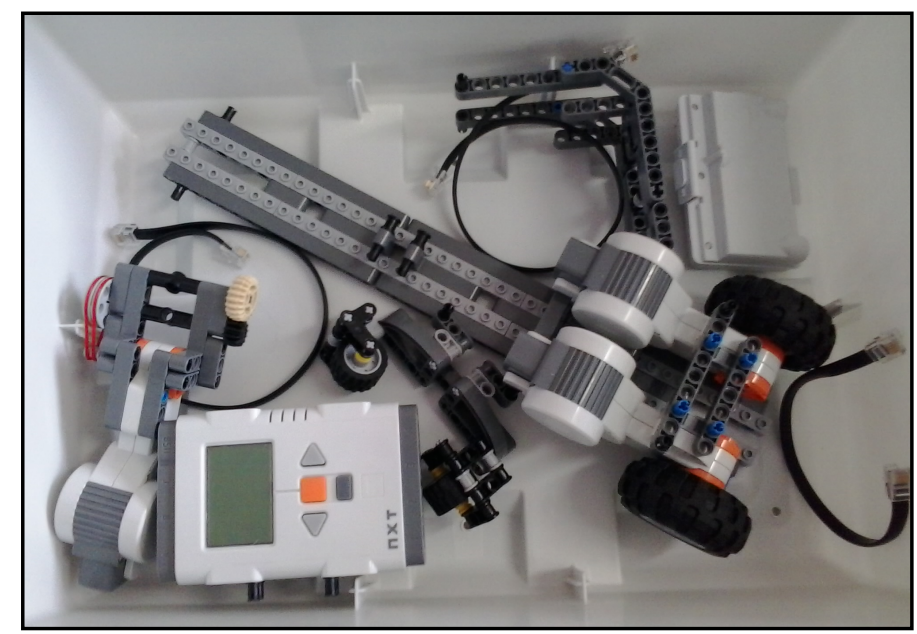

Figura 48 - Pré-montagem da empilhadeira fornecida aos estudantes na segunda aplicação. 
Conforme aponta a TAD, o momento tecnológico-teórico pode estar inserido no momento da institucionalização ou ser acompanhado deste. Percebe-se que isso se dá principalmente por conta da "oficialização" dos saberes disciplinares que são considerados mais relevantes daquela OP em jogo e/ou que possuem correlações entre a OP didática e a OP de referência. Vejamos:

$\mathrm{P}$ - Oh, vamos lá! Então, já identificaram ai [Diagrama de forças]. Oh, uma empilhadeira é construída sobre o princípio da gangorra. Quando a gente começou a falar, discutiu aqui sobre a empilhadeira e gangorra. A principio agente já achou que não tinha relação, né? Mas ele fala aqui, oh! - "A empilhadeira é construída pelo princípio da gangorra, princípio da alavanca de Arquimedes ou torque." - Então, quando falou de torque, tá relacionado com isso ai. Então você já começa a fazer relação entre o torque e o princípio da gangorra e agora tá falando da alavanca de Arquimedes.

$$
\text { (01:10:03 à 1:10:52). } 1^{\circ} \text { ano "B". }
$$

$\mathrm{P}$ - Então, olha bem, o que você ... é ... concluir em relação a isso aqui? Por exemplo: olha, antes esse menino aqui, que tem uma massa menor, ele não conseguia levantar o de massa maior, mas quando eu modifico o ponto de rotação, ele já consegui, inclusive igual ao que vocês falaram ai, equilibra. Então, eu teria um ponto de equilíbrio que, mesmo com corpos de massa diferentes, tenha o equilibrio, não é isso? Então, se eu tiver corpos com massas diferentes, é... ou melhor, corpos com massas iguais, onde é o ponto de equilibrio?

$\mathrm{A}_{1}-$ No meio.

$\mathrm{P}$ - Isso, no meio. Mas se eu tiver corpos com massas diferentes, esse ponto de equilibrio vai ...

[Vários alunos falam ao mesmo tempo]

$\mathrm{A}_{2}$ - ... tá mais próximo ao mais pesado.

$\mathrm{P}$ - Então, mais próximo ao mais pesado. Então, esse mais próximo tá relacionado com essa última medida que vocês fizeram que é o "b" [braço de alavanca da empilhadeira montada pelos alunos]. Então, para você, por exemplo, levantar uma carga maior, esse " $b$ " em relação ao ponto de apoio, esse " $b$ " tem que ser maior ou menor?

$\mathrm{A}_{1}-$ Menor.

$\mathrm{P}$ - Menor, certo? Consequentemente, aquele corpo de massa menor, esse " $b$ " pode ter um valor...

$\mathrm{A}_{1}$ - ... Maior.

$\mathrm{P}$ - Maior, é um inverso do outro, não é isso? Então, olha bem, isso é justamente o que vocês tem ai como o princípio da alavanca.

(02:30:16 à 2:32:14). $1^{\circ}$ ano "B".

$\mathrm{P}$ - Então, a medida que você vai colocando o corpo cada vez mais afastado, o que acontece com a capacidade de carga?

$\mathrm{A}_{1}-$ Diminui.

$\mathrm{P}$ - Vai diminuindo, certo? Então, a medida que você se aproxima do centro de rotação...

$\mathrm{A}_{1}$ - Aumenta. 
$\mathrm{P}$ - Vai aumentando, o que seria o princípio da...? Princípio da...? Vocês fizeram relação da empilhadeira com o que?

$\mathrm{A}_{2}-$ Da gangorra.

$\mathrm{P}$ - Da gangorra, não é isso!?

(03:13:50 à 03:14:22). $1^{\circ}$ ano "A".

Por outro lado, apesar da "oficialização" dos saberes disciplinares permear o momento da institucionalização, a modelização, que pode caracterizar o momento tecnológico-teórico, não é explorada com maior profundidade e rigor matemático nas duas aplicações da atividade empilhadeiras, o que pode acarretar prejuízos para realização plena da contextualização caso não seja retomada em outros momentos do processo de estudo (dentro ou fora da sala de aula, de modo individual ou coletivo).

Apesar de mencionados, os conceitos de torque e força não foram matematizados nessa atividade em particular. Percebe-se que há apenas uma anunciação do princípio da gangorra (ou princípio da alavanca) como conceito chave que possibilitaria melhor compreensão do funcionamento da empilhadeira e de sua capacidade de carga. Podemos interpretar que, nesse caso, o princípio da gangorra tem mais um papel de tecnologia $[\theta]$ e não de teoria $[\Theta]$, uma vez que encontramos na Física um discurso mais amplo e complexo, o qual tem potencial de gerar outras tecnologias que possibilitam melhor compreender a(s) técnica(s) adotada(s), como é o caso da lei de conservação da energia.

Há dois períodos bem demarcados que caracterizam o momento da avaliação, os quais envolvem aplicação de um pré e de um pós-teste (Anexo 1 e Anexo 2, respectivamente). As questões presentes nesses testes tratam de assuntos relativos ao conhecimento do aluno sobre equilíbrio, centro de massa e transporte de cargas.

De acordo com o pré-teste aplicado, todos os alunos do $1^{\circ}$ ano "B" e $90 \%$ dos alunos do $1^{\circ}$ ano "A" alegam que já brincaram de gangorra. Por outro lado, ao serem questionados sobre uma situação hipotética envolvendo gangorra (Figura 49), poucos alunos acertaram a alternativa correta (item ii) no pré-teste conforme aponta os gráficos seguintes (Figura 50). 
Questão 4: Duas crianças, com mesmo peso, sobem numa gangorra e seus pais seguram o banco até que elas estejam prontas para a brincadeira. Marque apenas com um $\mathbf{X}$, em qual (ou em quais) das situações ilustradas abaixo você acha que o Lado "A" da gangorra vai subir assim que os pais soltarem?

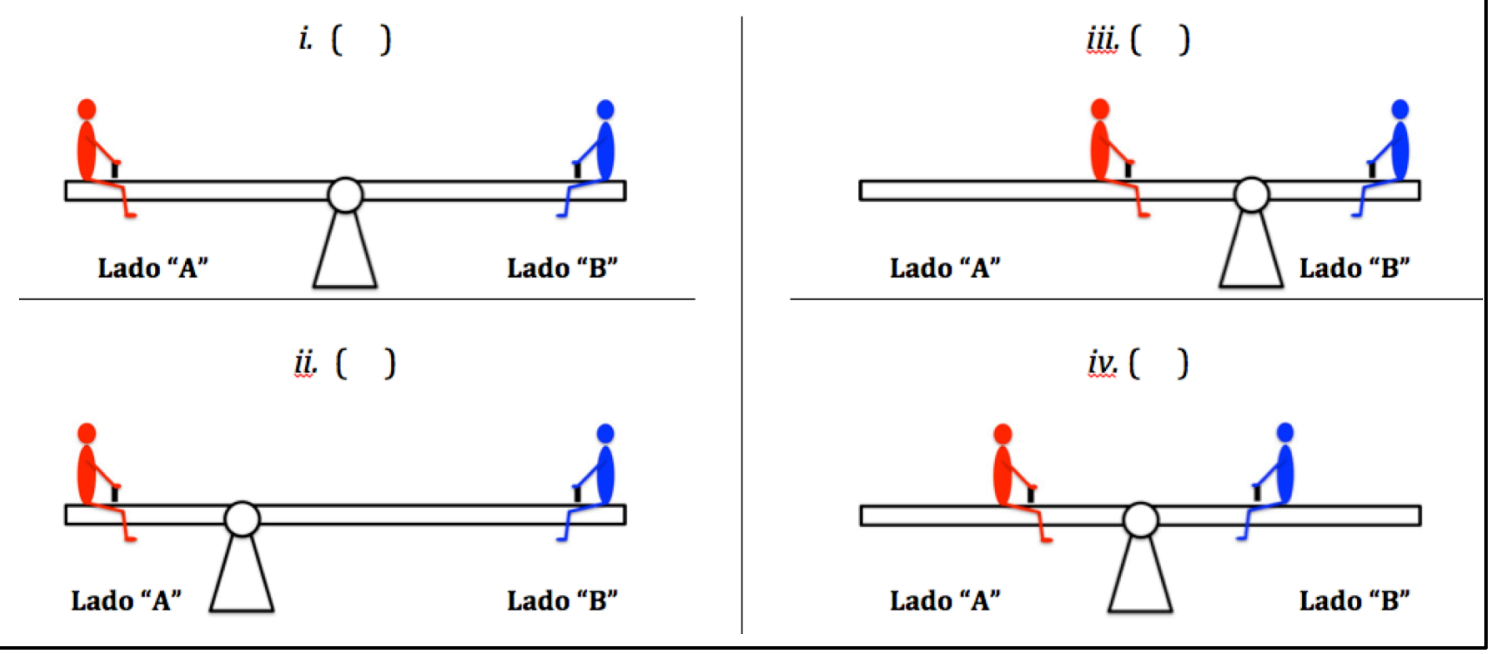

Figura 49 - Questão 4 do pré-teste: atividade “Empilhadeiras”.

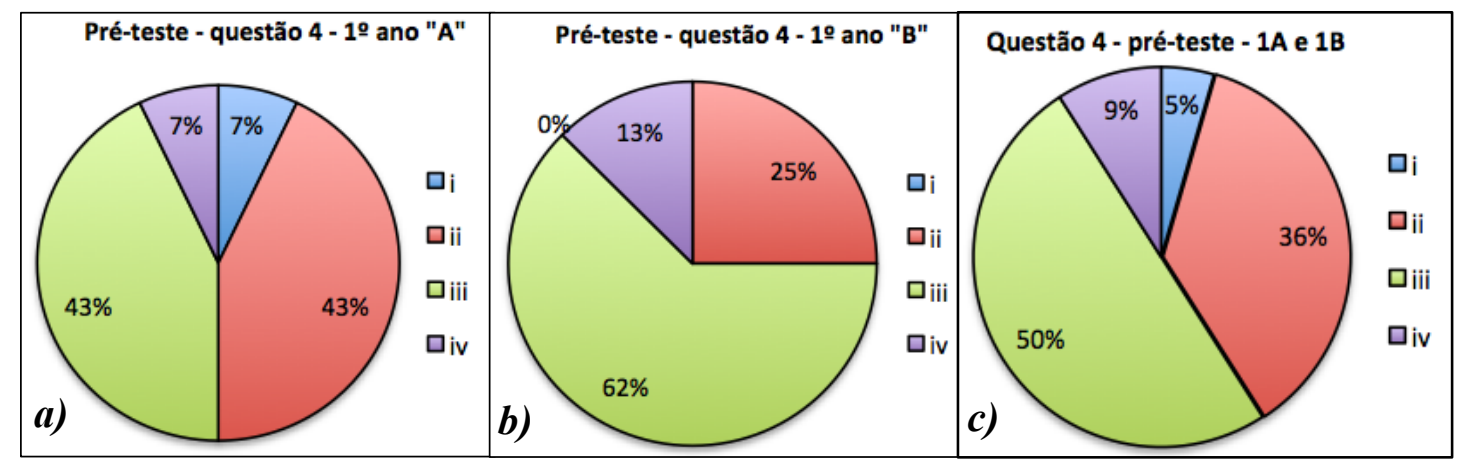

Figura 50 - Respostas a questão 4 do pré-teste: atividade "Empilhadeiras". a) Respostas apresentadas por alunos do $1^{\circ}$ ano "A". b) Respostas apresentadas por alunos do $1^{\circ}$ ano "B". c) Percentual das respostas considerando as duas turmas.

Obviamente, algumas respostas equivocadas podem ser atribuídas ao erro de interpretação da pergunta por parte do aluno. Este poderia se confundir e pensar, por exemplo, que a questão tratava do lado "B" e não do lado "A". Entretanto, mesmo após ter contato com essa questão no pré-teste e se submeter à OP didática, a qual tratava do princípio da alavanca através da atividade "empilhadeiras" e de discussões sobre a gangorra, a taxa de acertos nessa questão ainda permaneceu baixa (principalmente no $1^{\circ}$ ano “A”) quando aplicada no pós-teste (Figura 51). Essa questão no pós-teste (questão 3) sofreu pequenas alterações no enunciado, dessa vez, tratando do lado "B" da gangorra ao invés do lado "A", mas sua essência em termos conceituais permaneceu a mesma. O gráfico apresentado pela Figura 52c indica que apenas $31 \%$ dos estudantes (considerando as respostas apresentadas pelas duas turmas) 
assinalaram a resposta correta (item $i)$.

Questão 3: Duas crianças, com mesmo peso, sobem numa gangorra e seus pais seguram o banco até que elas estejam prontas para a brincadeira. Marque com um X, em qual (ou em quais) das situações ilustradas abaixo você acha que o Lado "B" da gangorra vai subir assim que os pais soltarem?

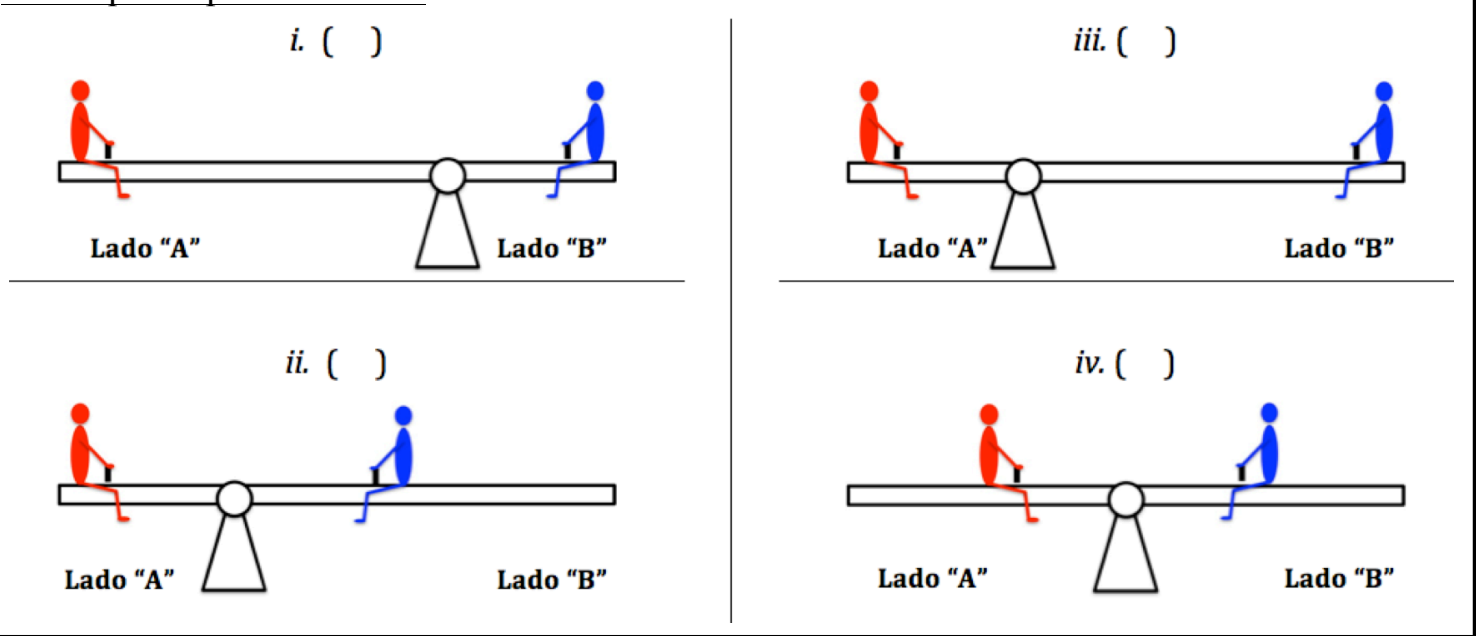

Figura 51 - Questão 3 do pós-teste: atividade "Empilhadeiras".
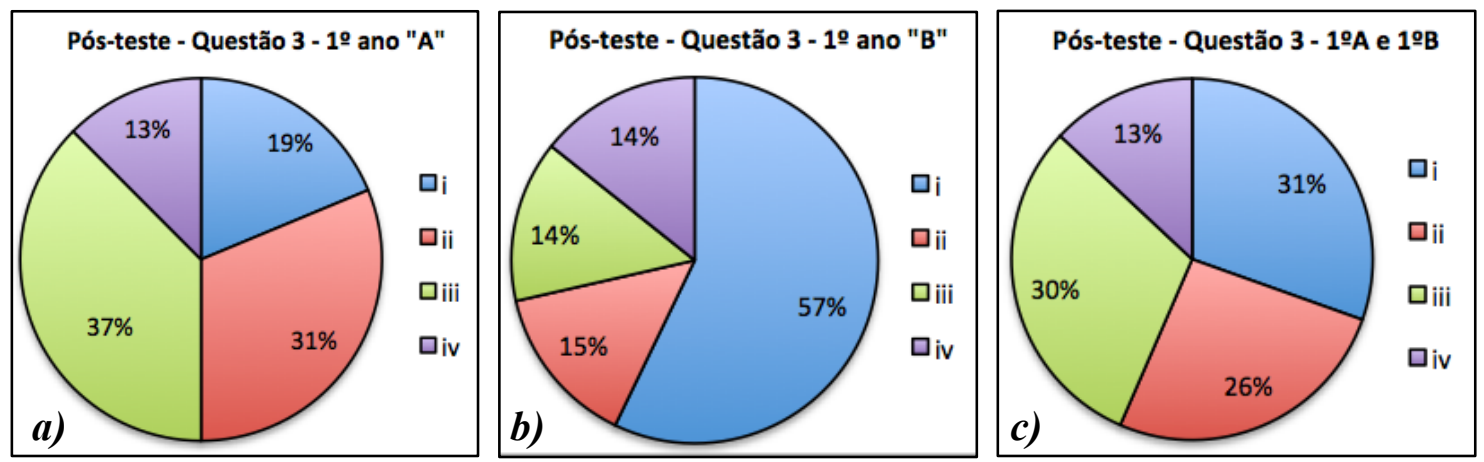

Figura 52 - Respostas a questão 3 do pós-teste: atividade "Empilhadeiras". a) Respostas apresentadas por alunos do $1^{\circ}$ ano "A". b) Respostas apresentadas por alunos do $1^{\circ}$ ano "B". c) Percentual das respostas considerando as duas turmas.

Curiosamente, nota-se que a taxa total de acertos (considerando as duas turmas) da questão sobre o movimento da gangorra no pós-teste foi menor (31\%) que no pré-teste (36\%). Por outro lado, os estudantes da turma do $1^{\circ}$ ano "B", que conseguiram uma taxa de acertos de $25 \%$ nessa mesma questão no pré-teste, atingiram $57 \%$ de acertos no pós-teste.

As outras duas questões do pós-teste (total de três) objetivam investigar o quanto os alunos são capazes de utilizar as técnicas e tecnologias supostamente apreendidas na OP didática (atividade "empilhadeiras") para resolver tarefas e melhor compreender outras técnicas presentes em contextos aparentemente distintos (outras OP de referência). Em outras palavras, objetiva-se investigar a relação do indivíduo $(\mathrm{X})$ com outros objetos $\left(\mathrm{O}_{\mathrm{n}}\right)$ ao seu redor ou presentes na sociedade de um modo geral, $\mathbf{R}\left(\mathbf{X}, \mathbf{O}_{\mathbf{n}}\right)$. 
Importante destacar que as questões 1 e 2 do pós-teste, aplicado ao término da atividade "empilhadeiras", apresentam propositadamente objetos que estão contidos em OPs de referência com bloco tecnológico-teórico idêntico ao tratado no estudo sobre o princípio físico de funcionamento de uma empilhadeira e de uma gangorra, ou seja, todos estão inclusos numa mesma organização praxeológica local $\left[\mathrm{T}_{\mathrm{i}}, \tau_{\underline{i}}, \theta, \Theta\right]$, centrada em torno de um mesmo bloco tecnológico-teórico.

A primeira questão do pós-teste, por exemplo, trata da dificuldade que uma pessoa apresenta para tirar os parafusos de uma roda de carro que está com o pneu furado, utilizando para isso uma chave em " $L$ ". O estudante é então indagado sobre o que a pessoa poderia fazer para tirar os parafusos aplicando a mesma força. Já a segunda questão, mostra o desenho de uma carroça, puxada por um animal e carregando um barril. Solicita-se ao estudante instruções de como melhor modificar sua estrutura e configuração para facilitar o transporte da carga. Essas duas questões, porém, envolvem essencialmente um mesmo logos, o princípio da alavanca (ou torque) que foi tratado na OP didática através da atividade "empilhadeiras".

As respostas dos estudantes apresentadas para as questões 1 e 2 aplicadas no pós-teste apontam que eles, em sua maioria, não foram capazes de utilizar de modo satisfatório, ao menos em curto período de tempo, os conhecimentos adquiridos na atividade e aplicar de imediato em outros contextos para resolver determinada tarefa. Em outras palavras, as alterações na relação do indivíduo com diferentes objetos, envolvendo outras OP de referência, ainda foram muito tímidas, indicando que eles não conseguiram de imediato efetuar "pontes" entre as duas $O P$, ou seja, $R(X, O) \Leftrightarrow R\left(X, O_{n}\right)$ partindo de objetos trabalhados na OP didática.

Na primeira questão, três alunos não responderam e apenas um único aluno (de um total de dezesseis, incluindo as duas turmas) respondeu de modo satisfatório, apresentando uma técnica que, de fato, poderia auxiliar a pessoa a tirar o parafuso da roda aplicando uma mesma força, a saber:

"Colocando um tubo de ferro ou uma ferramenta para alongar o cabo da chave". (A8) 32 .

Seguem exemplos de outras respostas apresentadas para a questão 1 do pós-teste (aplicado ao término da atividade "empilhadeiras"):

\footnotetext{
${ }^{32}$ A identificação dos estudantes nas respostas para as questões do pré e pós-teste não apresentam relação direta com a identificação utilizada nas falas transcritas dos momentos didáticos. 
"Ela poderia aplicar uma força maior da qual ela tinha usado antes, para poder conseguir tirar os parafusos." [sic] (A1).

"Girar no sentido contrário, talvez ela esteja girando pro lado errado". [sic] (A2).

“Mudar a posição". [sic] (A4).

“Usar o seu peso, a seu favor." [sic] (A6).

"Ela poderia utilizar o pé, para que o peso do seu corpo fose centralizada na chave”. [sic] (B2).

"Ela poderia aplicar uma força maior, usando talvez as duas mãos ou chutando a chave.". [sic] (B2).

Já para a questão 2, na qual se perguntava o que poderia ser mudado na estrutura da carroça e na disposição dos objetos para facilitar o transporte da carga pelo animal, todos os estudantes apresentaram alguma resposta, porém, ninguém conseguiu reunir todos os elementos necessários ou as modificações possíveis em uma única resposta. Vejamos algumas:

"A barra que conecta o animal a carroça poderia ser maior para poder facilitar o transporte." [sic] (A1).

"O barril poderia ser colocado para trás”. [sic] (A5).

"Colocar o Barril no fundo da carroça”. [sic] (A6).

“Colocar mais duas rodas, pois só com duas ele coloca mais força.”. [sic] (A9).

“Por o Barril no meio ou atrás Para diminuir o peso.". [sic] (A10).

"A carroça com 4 rodas facilitaria o transporte”. [sic] (B1).

"Teria que o Barril ir para o fundo da Carroça, para que o peso ficasse apoiado nas rodas”. [sic] (B2).

"As rodas da carroça teriam que ser colocadas no meio, para um melhor transporte da carroça”. [sic] (B5).

De um modo geral, interpretamos que tais resultados apontam para a necessidade de reformulações dessa atividade. Apesar da OP didática fomentar a contextualização para além do aspecto meramente ilustrativo, pois gerou oportunidades de alterar ou criar relações do indivíduo com diferentes objetos, $\mathrm{R}\left(\mathrm{X}, \mathrm{O}_{\mathrm{n}}\right)$, o momento tecnológico-teórico não foi apreendido de modo satisfatório pela maioria dos alunos. Além disso, aponta claramente para necessidade de uma continuidade (em sala de aula ou não e de modo individual ou coletivo) desse processo de estudo via a modelização dos saberes disciplinares (sob orientação do 
professor, com auxilio de material instrucional e/ou via atividades investigativas), caso seja de interesse do indivíduo o domínio de outros níveis de praxeologias (principalmente regional e global).

O domínio de outros níveis de praxeologias pode acarretar o contato com outras OP de referência conectadas por uma mesma teoria e/ou tecnologia como, por exemplo, as OP de referência ilustradas anteriormente nas questões 1 e 2 do pós-teste em contraponto com a atividade empilhadeiras, todas centradas ao redor do princípio da alavanca (tecnologia, $\theta$ ), configurando-se em uma organização praxeológica local.

Por fim, como era esperado, por se tratar de uma mesma atividade aplicada pelo mesmo professor, os momentos didáticos estão distribuídos de modo ligeiramente parecidos nas duas aplicações, ou seja, aparecem em instantes de tempo relativamente iguais. Entretanto, o tempo total ${ }^{33}$ dedicado para cada momento identificado no decorrer do processo de estudo não se assemelha, especialmente quanto ao momento de trabalho da técnica e do tecnológico-teórico (Tabela 14).

Tabela 14 - Tempo total aproximado dedicado para cada momento identificado na aplicação da atividade "Empilhadeiras".

\begin{tabular}{|c|c|c|}
\hline \multirow{2}{*}{$\begin{array}{c}\text { Momento Didático } \\
\text { (Atividade "Empilhadeiras") }\end{array}$} & \multicolumn{2}{|c|}{ Tempo total aproximado (em minutos) } \\
\hline & $\begin{array}{c}1 \text { ano "A" } \\
\text { (primeira aplicação) }\end{array}$ & $\begin{array}{c}1 \text { ano "B" } \\
\text { (segunda aplicação) }\end{array}$ \\
\hline Primeiro encontro & 29 & 37 \\
\hline Exploratório & 34 & 48 \\
\hline Tecnológico-teórico & 9 & 20 \\
\hline Técnica & 120 & 61 \\
\hline Institucional & 22 & 20 \\
\hline Avaliação & 10 & 20 \\
\hline
\end{tabular}

A diminuição do tempo dedicado ao momento de trabalho da técnica, na segunda aplicação, se deve principalmente ao fato da montagem não proceder a partir do zero, e sim ter sido apresentada de forma pré-montada, conforme exposto anteriormente. Já o aumento do tempo dedicado ao momento tecnológico-teórico se deve, em parte, a uma pequena discussão entre o professor e um grupo de alunos que buscava maiores esclarecimentos sobre questões do pós-teste. Além disso, o professor aparentou estar mais confortável com a atividade, na segunda aplicação, e apresentava uma maior afinidade com o material e contava com maior tempo para discutir questões de ordem conceitual e teórica (uma vez que o tempo de montagem foi reduzido praticamente pela metade).

\footnotetext{
${ }^{33} \mathrm{O}$ próprio software Videograph possui funções que apresentam para o usuário informações sobre o tempo total da ocorrência de cada categoria analisada. 


\subsection{2 - Atividade "Colisões".}

Por diversos fatores (greve de funcionários, semana de prova, paralisações, disponibilidade dos alunos e professores envolvidos, dentre outros), essa atividade contou com apenas uma única aplicação, porém, foi ampliada para todos os alunos das duas turmas, totalizando em 15 (quinze) participantes voluntários do primeiro ano (turmas A e B) do ensino médio do Colégio Modelo Luís Eduardo Magalhães em atividade extracurricular. Curiosamente, apesar da atividade ser aberta para as duas turmas, houve apenas participação de um único estudante da turma $1^{\circ}$ ano "B". Antes da aplicação dessa atividade, todos os alunos já haviam tido aula de Física envolvendo conteúdos disciplinares de cinemática, das três leis de Newton, plano inclinado, decomposição de forças e atrito, além de atividades prática através do lançamento de foguetes d'água sob orientação do professor da disciplina na escola.

Com relação à montagem, apesar de ser relativamente mais simples em comparação com a empilhadeira, optou-se também pela pré-montagem (Figura 53) para diminuir o tempo dedicado a essa fase.

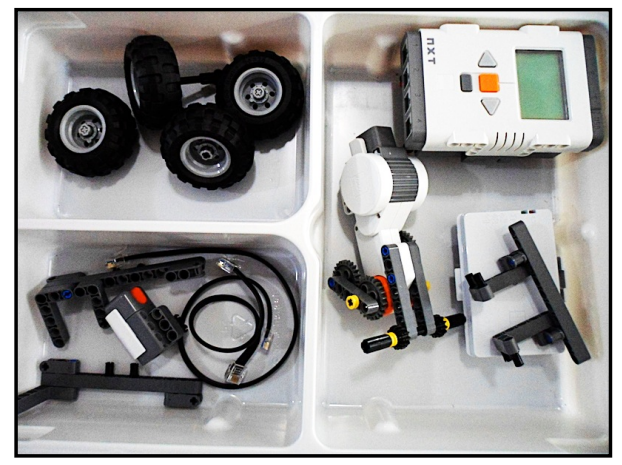

Figura 53 - Pré-montagem de veículo disponibilizado para os estudantes a ser utilizado na atividade "Colisões".

O processo de análise obedeceu aos mesmos procedimentos adotados anteriormente, gerando, assim, o seguinte gráfico para a atividade "colisões" (Figura 54).

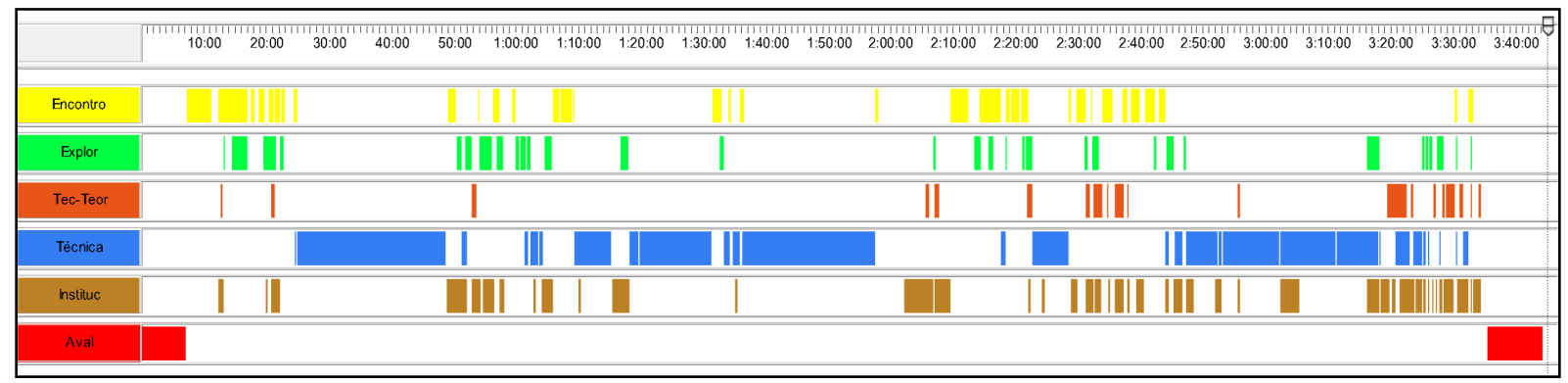

Figura 54 - Análise dos momentos didáticos: atividade "Colisões" 
O momento do primeiro encontro, intercalado com o exploratório, apresenta inicialmente algumas questões da OP de referência que são então exploradas na OP didática pela instituição, a saber:

$\mathrm{P}$ - "As batidas de carro podem ser perigosas, por isso a segurança para garantir a integridade física dos pilotos é uma questão crucial do regulamento. Vamos investigar uma parte desse regulamento. Para que possamos entender cientificamente o que garante a segurança da competição, nosso objetivo será compreender por que existem categorias e quais restrições existem quanto ao tipo de colisão. Como podemos fundamentar o regulamento? Quais as considerações necessárias para, por exemplo, separar as categorias? Como restringir os tipos de colisões?" Então, é... o que vocês... Essa primeira pergunta que ele [fascículo do aluno] coloca aqui, oh: "Como podemos fundamentar o regulamento?". Qual regulamento? Ele fala de que? É... fala que existem categorias, né? Deixa eu ver aqui...

$\mathrm{A}_{1}-$ A leve e a pesada.

$\mathrm{P}$ - A leve e veículos pesados, né? Por que eu tenho que separar por categorias?

[Vários alunos falam ao mesmo tempo]

$\mathrm{A}_{1}$ - Porque a força de um vai ser maior do outro.

$\mathrm{A}_{2}-[\ldots]$ vai destruir o leve, né?

$\mathrm{P}$ - Destruir o leve.

$\mathrm{A}_{1}$ - Por exemplo, leve com leve para poder ter uma... uma força igualmente.

$\mathrm{A}_{2}-$ Tem que ser semelhantes.

$\mathrm{P}$ - Você acha que essa questão das categorias, onde é que você vai ver isso também em esportes?

$\mathrm{A}_{3}-M M A$ !

$\mathrm{P}$ - MMA. Tem em MMA essa categoria de massa?

[Vários alunos falam ao mesmo tempo]

$\mathrm{P}$ - Por exemplo, peso pesado, peso pena ... que é do Boxe, né? Mas assim... em relação ao MMA eu não conheço muito bem as regras.

[...]

$\mathrm{A}_{3}-$ É porque não pode um magrinho com um fortão.

$\mathrm{P}$ - Veja bem, por que não pode um magrinho com um fortão?

$\mathrm{A}_{3}$ - Porque o fortão vai destruir o magrinho.

$\mathrm{A}_{4}-$ Nem sempre.

$\mathrm{A}_{2}$ - Não! Porque Davi derrubou Golias.

[Risos]

$\mathrm{A}_{4}$ - Nem sempre, porque o homem mais forte perde a velocidade e o cara magrinho pode ganhar, entendeu? O cara forte ele perde o... como é o nome?

$\mathrm{A}_{5}-$ Velocidade.

$\mathrm{A}_{4}-A$ velocidade.

$\mathrm{A}_{6}-\dot{E}$ mais peso pra ele...

$\mathrm{A}_{7}-$ Ele tem mais agilidade.

$\mathrm{A}_{5}-\dot{E} !$

[Tumulto, vários alunos narram ao mesmo tempo algum episódio de luta que já assistiram na TV]

(00:13:34 à 00:16:20). Atividade “Colisões". 
Interessante notar que, nesse momento de primeiro encontro e exploratório da atividade "colisões", surgiram questões de OPs de referência que não são citadas no fascículo (seja do professor ou do aluno), tais como questões sobre o peso de lutadores de Boxe e de MMA. Isso é indicativo de que o processo de contextualização é extrapolado (nesse caso, na parte da problematização inicial) para além dos limites previamente demarcados na OP didática, em que o foco era determinada OP de referência (colisão entre veículos). Desse modo, é possível o surgimento de Verossimilhanças Praxeológicas (por correspondência ou por interseção) entre OPs de referência não tratadas diretamente na OP didática, mas que, pelo processo de estudo, vão ganhando espaço e precisam ser exploradas em alguma oportunidade pela instituição.

O primeiro extrato em azul, entre os instantes 00:24:30 e 00:48:26, remete a montagem dos veículos, entregues aos alunos na forma pré-montada, e configura-se no primeiro momento de trabalho da técnica dessa atividade. A análise indica o surgimento de vários momentos de trabalho da técnica, com períodos de tempo relativamente longos em comparação aos demais. Isso ocorre, principalmente, por conta da atividade "colisões" apresentar um número maior de tarefas a serem executadas, desde a execução do experimento e a coleta dos dados experimentais (Figura 55), até a conversão de unidades e cálculos da velocidade e da quantidade de movimento dos veículos antes e após a colisão. Os alunos contaram com auxílio de uma calculadora eletrônica padrão para efetuarem as operações matemáticas.

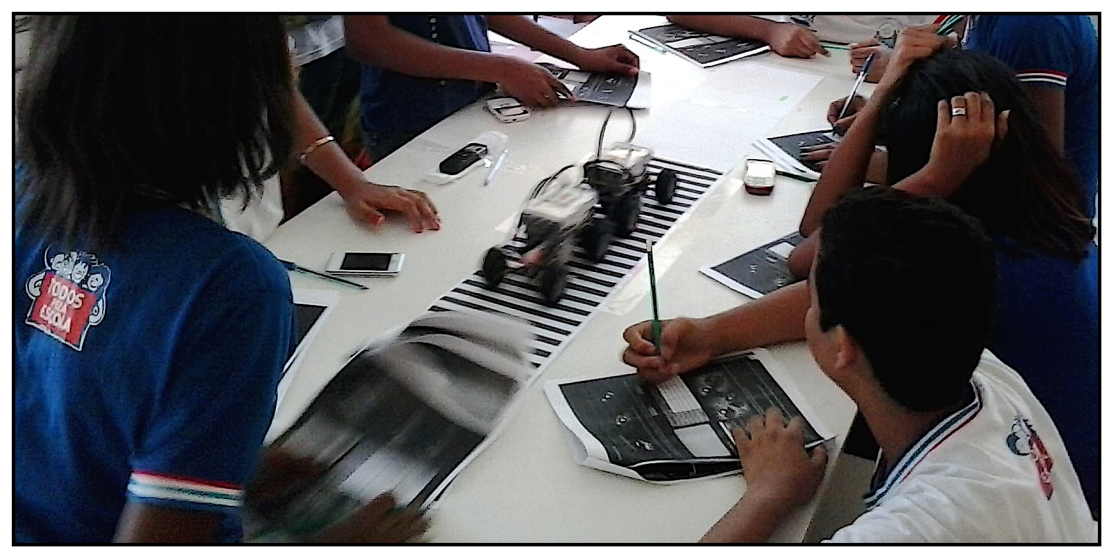

Figura 55 - Momento da coleta dos dados experimentais para calcular a velocidade dos veículos.

Como o professor necessitou apresentar com maior frequência as situações e expor as tarefas e os problemas que deveriam ser investigados e resolvidos, chamando atenção para esse ou aquele ponto, percebe-se também o surgimento de vários momentos referentes à 
institucionalização, alguns mesclados com o momento do primeiro encontro e exploratório, a saber:

$\mathrm{P}$ - Olha bem, é... antes de fazer a prática, vou chamar atenção para duas informações que são apresentadas pelo NXT, certo?

$\mathrm{A}_{1}-O q u e$ ?

$\mathrm{P}$ - NXT é essa caixinha, o computador. Ele controla todo esse carrinho. Então, eu tenho dois carrinhos ai. Um cabo vai para o sensor, certo? $O$ sensor ele vão o que? Detectar alguma informação. No caso ai, informação do sensor de luz, né? E o outro sensor, do outro carro, e vai controlar o motor. $O$ carinho que você encaixou ai nessa parte de baixo, ele controla o motor. Ai ele diz, lá na programação, né? Você faz tudo isso no computador. Eu quero que esse motor fique funcionando durante... sei lá, até o momento que ele chegar na faixa preta. Na primeira faixa preta. Quando ele chegar na primeira faixa preta ele desliga o motor. Você vai ver que essa engrenagem vai sair do lugar e o carro continua em movimento.

$[\ldots]$

$\mathrm{P}$ - Então, é... esse computadorzinho ele vai informar pra vocês alguns valores, a gente vai ter que ficar atento em relação a isso. Quando vocês fizerem a prática, que houver o choque e tudo. É... tenta não mexer muito no... principalmente no carro A porque ele vai pegar sete valores, certo? E o carrinho $B$ vai apresentar três valores pra vocês, e esses valores são valores de tempo. Ai vocês vão ver assim, oh ...

(00:48:59 à 00:50:56). Atividade "Colisões".

$\mathrm{P}$ - Oh, atenção aqui. Atenção. Mais uma vez... mais uma vez. Oh, você não tem essa tabelinha aqui, oh...

[gestos apontando para dados no quadro].

$O$ quadro "A", ai tem $t_{1}$ e $t_{2}$. Quem é $t_{1}$ ? $t_{1}$ é antes da batida, certo? Antes de ele chegar a tocar o outro carro. E $t_{2}$ é após a batida. Então como eu vou pegar $t_{1}$ e $t_{2}$ e botar aqui no "A"? Aquele que eu falei pra vocês que não pode mexer, que tem que tomar cuidado. Bom, eu vou pegar esse aqui, oh [gestos apontando para dados no quadro].

$\mathrm{P}-$ Ele [NXT] vai apresentar sete valores, se não apresentar você refaz o experimento, tá bom? Então aqui, oh: um, dois ... esse valor aqui, o terceiro, é nosso querido $t_{1}$. Então você vai pegar e vai encontrar o valor, não é isso? Esse valor que vocês viram na primeira medida ai, não foi alguma coisa assim: 26, 32 .. não foi?

$\mathrm{A}_{2}-$ Ah hã.

$\mathrm{P}$ - Então, olha bem, isso está em milissegundos. Então o que você faz?

$\mathrm{A}_{3}-$ Converte.

$\mathrm{P}$ - Converte, divide por mil. Ou seja, esse 26 vá virar quanto? 0,026, ai coloca lá na tabelinha, certo? E qual o outro valor aqui que eu coloco no $t_{2}$ ? $t_{2}$ é o sexto valor, aqui oh ...

[gestos apontando para dados no quadro].

$\mathrm{P}-$ Ai você vai ter dois valores. Depois segue o mesmo procedimento ... [gestos apontando para dados no quadro].

$\mathrm{P}$ - Joga a virgula ... né? Ou dividi por mil e você vai ter ... sei lá, se aqui for 106, ai você bota aqui 0,106, tá bom?

(01:16:08 à 01:17:34). Atividade "Colisões". 
De um modo geral, quando se identifica a institucionalização surgindo quase que simultaneamente com o momento exploratório e/ou com o momento de trabalho da técnica, percebe-se que o professor interfere diretamente no processo de estudo e trabalha principalmente de modo expositivo. Assim, na maioria das vezes, ele apresenta no quadro os objetos manipulados inicialmente pelos estudantes, chamando atenção para esse ou aquele procedimento. Isso ocorre especialmente quando os alunos apresentam alguma dificuldade e não conseguem avançar na resolução da tarefa ou do problema em questão, a exemplo da transcrição anterior.

O momento tecnológico-teórico, mesclado também pela institucionalização, discute essencialmente questões sobre conservação da energia, fazendo menção a outras OP de referência como, por exemplo, transformações da energia elétrica em luminosa e térmica ao acender uma lâmpada, a saber:

$\mathrm{P}$ - Pra gente continuar e falar da quantidade de movimento, é interessante que vocês compreendessem isso daqui primeiro, certo? Então oh, se eu digo que a energia se conserva, e antes eu tinha energia elétrica aqui, tinha 10, depois, que eu tenho energia luminosa e térmica, o tal tem que ser quanto?

$\mathrm{A}_{3}-$ Vinte.

$\mathrm{A}_{2}-N \tilde{a} o$.

$\mathrm{P}$ - Então, se aqui for 20, ela não se conservou, certo? Então aqui eu tenho que ter?

$\mathrm{A}_{2}-$ Dez.

$\mathrm{P}-$ Dez. Desses 10, uma parte é luminosa e outra parte é térmica...

$\mathrm{A}_{2}-$ Calor.

$\mathrm{P}$ - ... mas somando... tem que ser igual a 10. Se eu digo que a energia se conserva, antes tem que ser igual a...

$\mathrm{A}_{3}-$ Depois.

$\mathrm{P}-$ Depois.

$\mathrm{A}_{2}-$ Pode ser 5 e 5 .

$\mathrm{P}$ - Pode ser também! Uma eficiência de 50\%. 50\% de energia transformada em luz. $50 \%$ de energia convertida em calor. Quando você soma tem que da o total que é 10. E antes tinha quanto? Dez. Então, a energia se conservou. De fato, a energia vai ser conservada. Ela é transformada, mas ela sempre vai ser conservada. E quando eu falo de quantidade de movimento, eu tenho uma coisa bem parecida, certo? Então, eu vou falar aqui, oh. Quantidade de movimento antes tem que ser igual á quantidade de movimento depois.

(02:35:45 à 02:36:59). Atividade "Colisões".

Essa discussão sobre a conservação da energia, trazendo objetos de uma outra OP, contribui para que o processo de contextualização se torne mais rico, uma vez que possibilita mudar a relação do sujeito $(\mathrm{X})$ com diferentes objetos $\left(\mathrm{O}_{\mathrm{n}}\right)$, envolvendo outras $\mathrm{OP}$ de referência dentro de uma mesma OP didática. 
O momento da avaliação é demarcado principalmente pela aplicação do pré (primeiros dez minutos da aula) e do pós-teste (ao término da aula) (Anexo 3 e Anexo 4, respectivamente). De acordo com as respostas apresentadas no pré-teste, envolvendo, direta ou indiretamente, questões sobre colisões e corpos em movimento, 73\% dos estudantes alegaram que já presenciaram uma situação de colisão entre dois carros ou motos, 93\% nunca sofreram algum acidente de trânsito, 93\% já brincaram de jogar bolinhas de gude, $73 \%$ já andaram de patins e $87 \%$ já brincaram de carrinho bate-bate (brinquedo comum nos parques de diversão).

Com base nessas respostas, podemos afirmar que a relação $\mathrm{R}(\mathrm{X}, \mathrm{O})$ não é nula, ou seja, os alunos possuem relação de alguma ordem com os objetos que permeiam, direta ou indiretamente, a temática central "colisões". Entretanto, quando é solicitado aos alunos citarem quatro principais grandezas físicas que na opinião deles atuam numa situação de colisão (questão 6 do pré-teste), grandezas como massa, velocidade e força surgem no total das respostas com pouca frequência, conforme mostra o gráfico ilustrado na Figura 56, apontando que $\mathrm{R}(\mathrm{X}, \mathrm{O})$ referente a uma situação de colisão não contempla ainda de modo satisfatório os saberes disciplinares, nesse caso, da Física.

A questão 6 do pré-teste foi apresentada também no pós-teste (questão 1), resultando num significativo aumento de ocorrências para as grandezas "Força", "Massa" e "Velocidade" (Figura 57), sugerindo, desse modo, que houve mudanças na relação R(X,O) da OP de referência após o processo de estudo e contextualização. Em ambos os gráficos a categoria "Outros" envolve termos como "Ação e Reação", "Peso", "Vetorial" e "Volume".

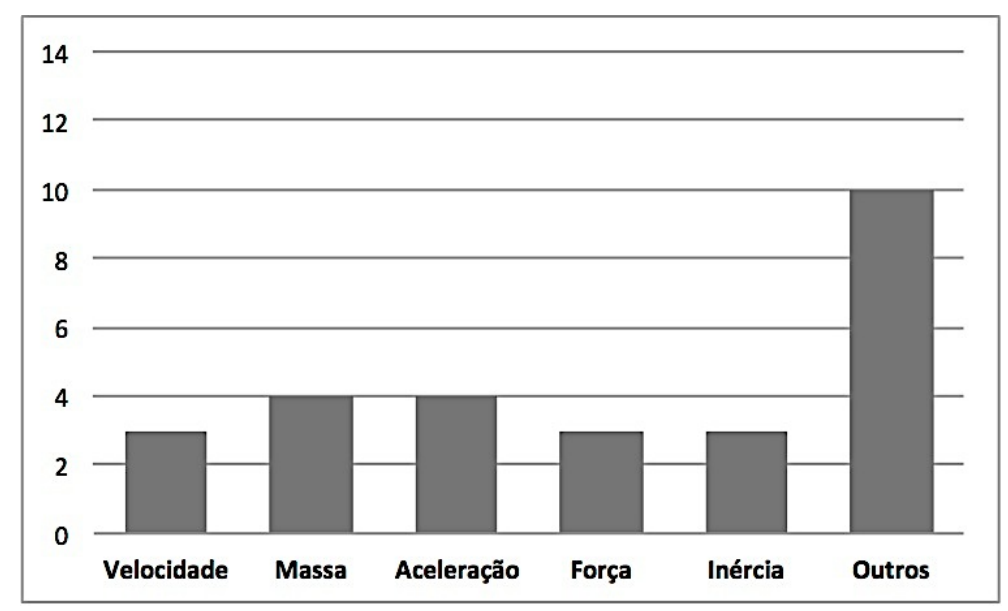

Figura 56 - Respostas apresentadas pelos alunos para a questão 6 do préteste: atividade "Colisões". 


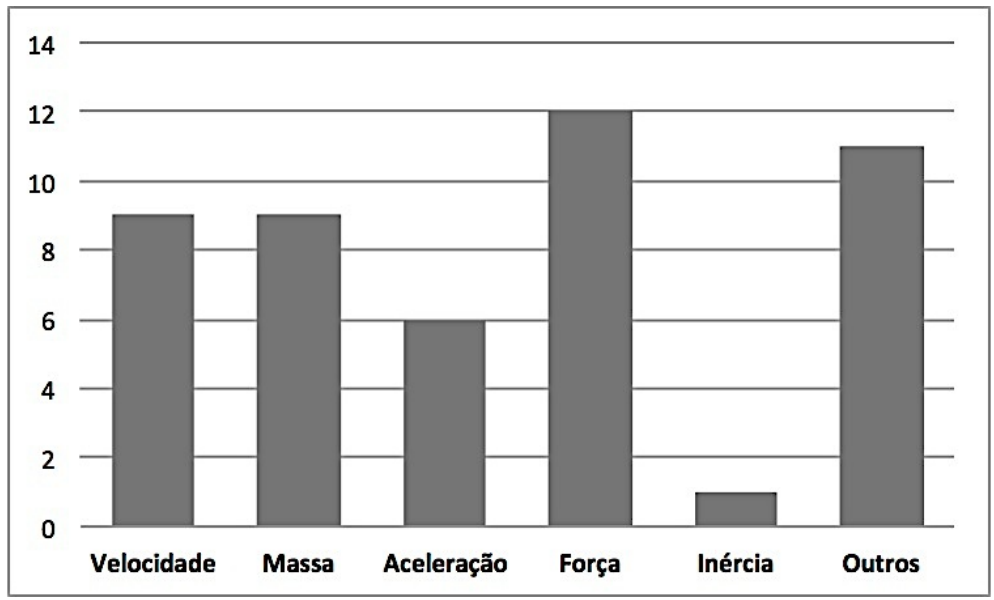

Figura 57 - Respostas apresentadas pelos alunos para a questão 1 do pósteste: atividade "Colisões".

Apesar dos indícios de criação ou da modificação da relação dos estudantes com objetos da OP de referencia trabalhados na OP didática, as respostas dos alunos referentes à questão 4 do pós-teste (Figura 58) apresentam evidências de que tais relações são ainda de caráter superficial, sem maiores domínios dos saberes disciplinares, especialmente no nível da matematização.

A questão 4 tratava da colisão frontal entre dois carrinhos de bate-bate, brinquedo comum nos parques de diversão e com o qual $87 \%$ dos estudantes alegaram, no pré-teste, já ter brincado. Todavia, conforme aponta o gráfico ilustrado pela Figura 59, apenas 20\% dos estudantes marcaram a resposta correta (item c), indicando deficiências do sujeito no domínio da técnica $(\tau)$ e/ou de compreensão do bloco tecnológico-teórico $[\theta, \Theta]$ trabalhado na $\mathrm{OP}$ didática ao longo do processo de estudo e de contextualização.

Questão 4: Conforme ilustrado abaixo, Pedro e seu carrinho de bate-bate (juntos possuem 50kg) colide frontalmente a $2 \mathrm{~m} / \mathrm{s}$ no carro de João, ambos ficam com os veículos parados imediatamente após a colisão. Qual era a velocidade do veículo de João (juntos possuem 100kg) antes da colisão? Considere que não há perdas de energia, ou seja, sistema ideal. Marque abaixo a alternativa que você acha correta.

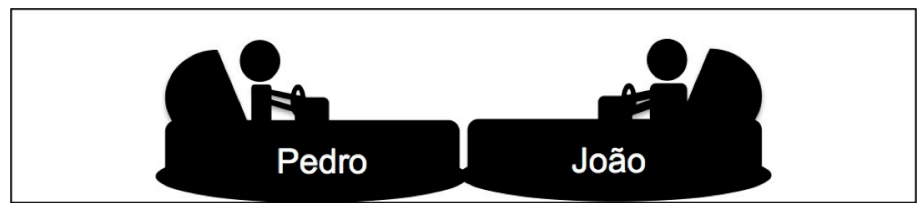
a) $3 \mathrm{~m} / \mathrm{s}$
b) $-2 m / s$
c) $-1 \mathrm{~m} / \mathrm{s}$
d) $4 \mathrm{~m} / \mathrm{s}$

Figura 58 - Questão 4 do pós-teste da atividade "Colisões". 


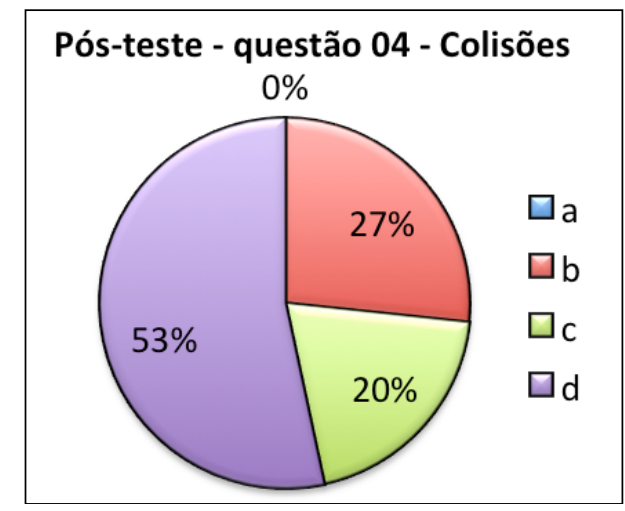

Figura 59 - Respostas apresentadas para a questão 4 do pósteste da atividade "Colisões".

Destacamos ainda a questão 3 do pós-teste, que corresponde exatamente a mesma questão 7 presente no pré-teste. Essa questão informa que para deter um navio superpetroleiro, suas máquinas são desligadas usualmente a uns $25 \mathrm{~km}$ do porto. O estudante é então indagado por que é tão difícil parar ou fazer voltar um superpetroleiro. No pré-teste, predominaram respostas que envolviam a massa ou o peso do navio. Já no pós-teste, além do peso ou da massa do navio, surgiram algumas respostas que acrescentavam também a força de atrito como principal fator de dificuldade para manobrar um superpetroleiro. Curiosamente, nos dois testes, em nenhuma das respostas a esta questão, verificou-se o termo "quantidade de movimento" ou "momento linear", houve apenas uma única ocorrência do termo "lei da inércia” que apareceu no pré-teste. Vejamos algumas respostas:

"Por causa da massa do navio." [sic] (C2, Pré-teste).

"Por causa da quantidade de massa do navio." [sic] (C2, Pós-teste).

"Da lei da Inércia." [sic] (C3, Pré-teste).

"Por causa da sua massa." [sic] (C3, Pós-teste).

"Por que ele é pesado e presisa de uma força maior para si deslocar." [sic] (C7, Pré-teste).

"Pois a força de atrito que possui entre a água e o navio faz com que ele demore mais para para." [sic] (C7, Pós-teste).

"Por causa do valor da massa." [sic] (C8, Pré-teste).

"Por causar da força de atrituto." [sic] (C8, Pós-teste).

“Porque sua massa é enorme." [sic] (C11, Pré-teste).

"Porque sua massa é enorme e sua força de atrito se torna maior por causa disso." [sic] (C11, Pós-teste).

"É dificil por causa do seu tamanho e massa." [sic] (C12, Pré-teste). "Por causa que um navio superpetroleiro é muito pesado e tênde a continuar em movimento." [sic] (C12, Pós-teste). 
Em linhas gerais, podemos afirmar que essas respostas indicam que as relações do indivíduo com os objetos (conceituais, teóricos, práticos, dentre outros) trabalhados na OP didática não implicaram de modo significativo em alterações na relação dos estudantes com objetos contidos em outras OP de referência, ainda que, dentro de uma organização praxeológica local.

Por fim, o tempo total dedicado para cada um dos momentos didáticos identificados na aplicação dessa atividade é apresentado a seguir (Tabela 15).

Tabela 15 - Tempo total aproximado dedicado para cada momento identificado na aplicação da atividade "Colisões".

\begin{tabular}{|c|c|}
\hline $\begin{array}{c}\text { Momento Didático } \\
\text { (Atividade "Colisões") }\end{array}$ & Tempo total aproximado (em minutos) \\
\hline Primeiro encontro & 41 \\
\hline Exploratório & 27 \\
\hline Tecnológico-teórico & 15 \\
\hline Técnica & 115 \\
\hline Institucional & 52 \\
\hline Avaliação & 16 \\
\hline
\end{tabular}

Constatou-se um longo período de tempo dedicado ao momento de trabalho da técnica (cerca de 115 minutos) e da Institucionalização (cerca de 52 minutos), sugerindo se tratar de uma atividade de caráter mais rígido e mecânico, com poucos momentos destinados a exploração (em torno de 27 minutos), especialmente quando comparado com a atividade empilhadeiras (cerca 41 minutos dedicados a exploração).

\section{4 - Desenvolvimento de atividades didáticas por Verossimilhança Praxeológica.}

Uma vez que a OP didática analisada e aplicada remete aos fascículos da Lego, é natural que os kits de robótica da mesma sejam adotados para o desenvolvimento das montagens. Entretanto, vale salientar que para explorar determinada OP de referência, fazendo uso de elementos da robótica educacional, dentro de um processo didáticopedagógico de contextualização, não é necessária a exclusividade de quaisquer kits e recursos materiais didático-pedagógicos. Por exemplo: uma OP didática, que adota como OP de referência uma lombada eletrônica ou "pardal" para discutir questões que permeiam medição autônoma de velocidade e segurança no trânsito, pode muito bem construir esse mesmo dispositivo fazendo uso de diferentes sensores e kits, desde os materiais mais sofisticados até materiais de baixo custo e reutilizáveis. Por essa razão, nossas propostas de desenvolvimento e análise de atividades didáticas independem do tipo de material ou kit de robótica 
educacional adotado.

Se partirmos de uma determinada atividade humana, inserida numa dada realidade, podemos então investigar essa atividade, tratando-a como uma organização praxeológica (OP de referência). Assim, dependendo da intenção didática, pode-se extrair dessa investigação da OP de referência quais tarefas, técnicas, tecnologias ou teorias se deseja tratar ou são mais viáveis para constar na atividade didática (seja por Verossimilhança Praxeológica de interseção ou correspondência).

Para ilustrar essa proposta, tomamos como exemplo o caso da lombada eletrônica, presente em praticamente todos os centros urbanos e rodovias (Figura 60).

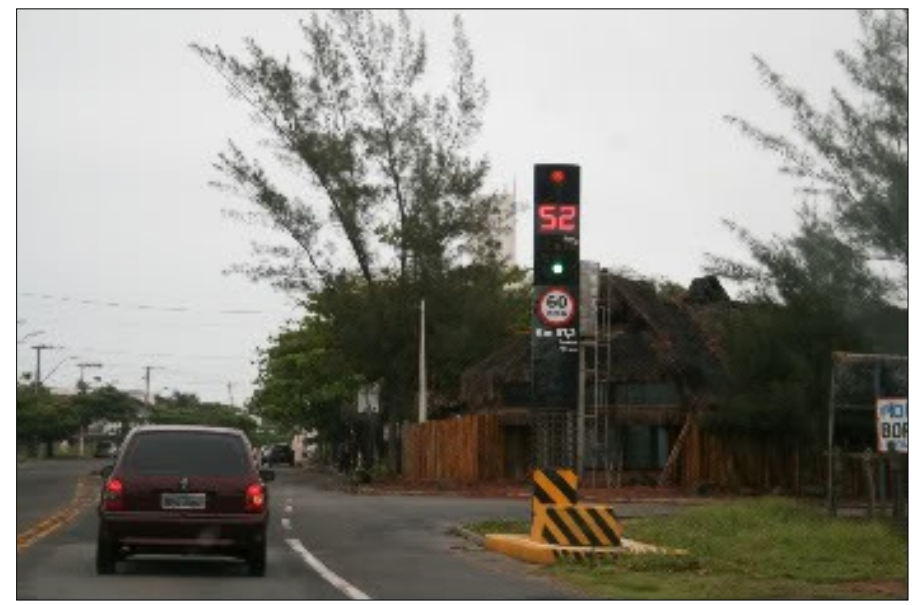

Figura 60 - Lombada eletrônica, comum em grandes centros urbanos.

O princípio de funcionamento desse tipo de lombada envolve a perturbação do campo eletromagnético, gerado por bobinas instaladas na pista abaixo do asfalto. Duas bobinas (do tipo laço magnético) são posicionadas na pista a uma distância pré-determinada uma da outra. Tais bobinas são instaladas cerca de 20 metros antes da torre (que exibe a velocidade) e no sentido do fluxo do trânsito. Quando a velocidade registrada for superior ao limite permitido e a margem de tolerância for superada uma máquina fotográfica é acionada.

O laço, quando energizado, funciona como um indutor, criando um campo magnético ao seu redor. Com a passagem de veículos sobre ele, ocorre uma alteração no campo magnético, devido às correntes de Foucault, que aparecem nas partes metálicas dos veículos. O princípio explorado por este projeto é o de que cada veículo provoca uma alteração particular neste campo magnético, ou seja, cada veículo deixa a sua 'assinatura' própria ao passar sobre o laço de corrente. Portanto, basta medir a variação no campo magnético para se saber qual o veículo que está passando sobre o laço. [...] Para o cálculo da velocidade de um veículo, usam-se dois laços. A velocidade é obtida dividindo-se a distância entre os mesmos pelo tempo 
transcorrido entre dois picos dos sinais dos laços. (BARBOSA et al, 2004, pp. 662-663).

Percebe-se que uma das técnicas para a determinação da velocidade do veículo envolve um cálculo simples de cinemática. Por outro lado, um processo mais complexo, evolvendo séries matemáticas e lógica de programação, é exigido para se determinar o tipo de veículo. Assim, "o sinal do carro possui uma maior amplitude nas baixas frequências, enquanto que o sinal do caminhão, por exemplo, possui amplitude relevante apenas em algumas frequências (específicas).” (BARBOSA et al, 2004, p.668). Por meio da diferença entre essas amplitudes dos sinais em frequências específicas é possível caracterizar o tipo de veículo, acusando assinaturas próprias. O mapa conceitual representado pela Figura 61 sintetiza essa prática social de referência e apresenta os principais componentes e princípios físicos que regem o funcionamento de uma lombada eletrônica.

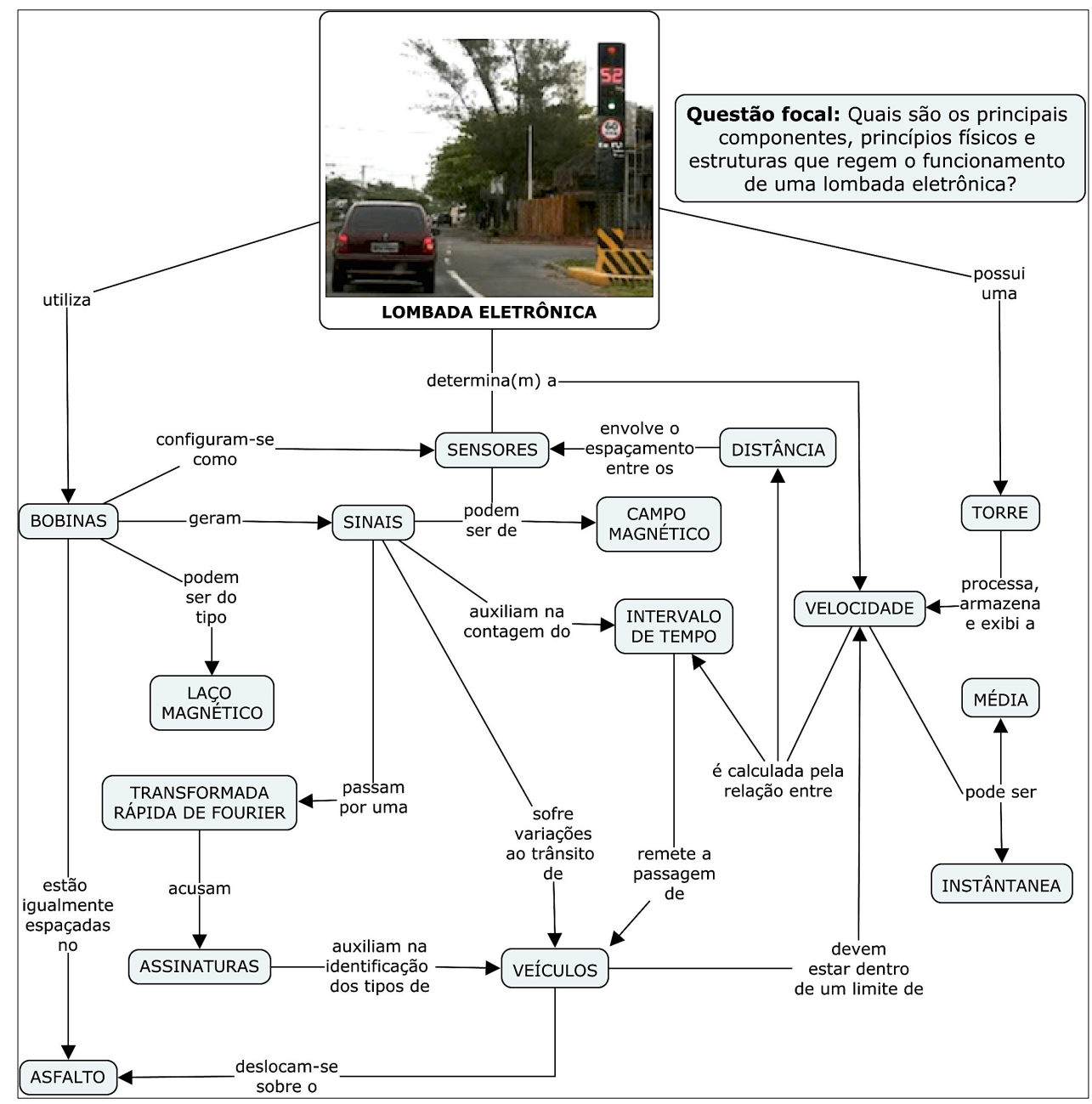

Figura 61 - Mapa conceitual referente aos principais aspectos estruturais e conceituais identificados na OP da prática social de referência - "Lombada Eletrônica". 
Por meio da robótica educacional, é possível tratar esse sistema e explorar essa prática de referência na sala de aula. Mas é preciso estar claro quais tarefas, técnicas, tecnologias e/ou teorias se deseja explorar da OP de referência. Além disso, é preciso checar como determinados elementos vão surgir na OP didática, se é através de uma Verossimilhança Praxeológica por interseção, correspondência ou ambas.

Em primeira análise, nos parece que o tipo de tarefa (determinar a velocidade de veículos que passam num trecho) e a principal técnica associada a esse tipo de tarefa (dispor detectores na pista de tal modo que o tempo transcorrido entre dois picos dos sinais detectados sejam processados pela torre para calcular a velocidade) tratam de uma VP por interseção. Assim, a OP didática pode conter exatamente o mesmo tipo de tarefa e a mesma técnica contida na OP de referência, enriquecendo a quantidade de elementos praxeológicos que podem ser trabalhados na problematização e, em seguida, discutidos no processo de modelização. Nesse momento, é possível tratar conceitos físicos como velocidade média, velocidade instantânea, aceleração média e aceleração instantânea, além da discussão sobre as formas/técnicas para se registrar e mensurar o tempo transcorrido entre os sinais que acusam a passagem do veículo.

Fazendo uso de componentes da robótica podem-se desenvolver várias montagens que permeiam diferentes técnicas para cumprir o tipo de tarefa principal (determinar a velocidade do veículo). É possível se valer de vários tipos de sensores, desde o ultrassom e infravermelho até o sensor de luz, bem como de diferentes materiais e montagens, a partir dos quais o aluno é levado a investigar a melhor opção, tanto em termos de eficiência na medição quanto em termos de complexidade da montagem. Sua criatividade é então valorizada e o raciocínio lógico para a resolução do problema torna-se de suma importância, envolvendo conceitos físicos e matemáticos. Isso tudo ocorre dentro do que denominamos de VP por correspondência. Nesse caso, aluno não vai trabalhar com os mesmos equipamentos e materiais presentes na OP de referência, porém, há correlações diretas com os utilizados na RE, a exemplo dos sensores empregados para acusar a passagem do veículo.

A Figura 62 apresenta algumas opções de modelos de sensores que podem ser empregados na OP didática para desenvolver a montagem da lombada eletrônica via Arduino. Alguns são mais caros, porém, é possível realizar a atividade com sensores de baixo custo, a exemplo dos sensores de infravermelho (IR) e o de intensidade de luz (LDR). Dependendo do sensor adotado, são necessários uma programação específica e um hardware apropriado, além 
de adequada organização dos componentes. Segue exemplo (Figura 63) de uma possibilidade de montagem para ser desenvolvida com os alunos, pois contêm componentes de baixo custo e a programação necessária é relativamente de fácil compreensão.

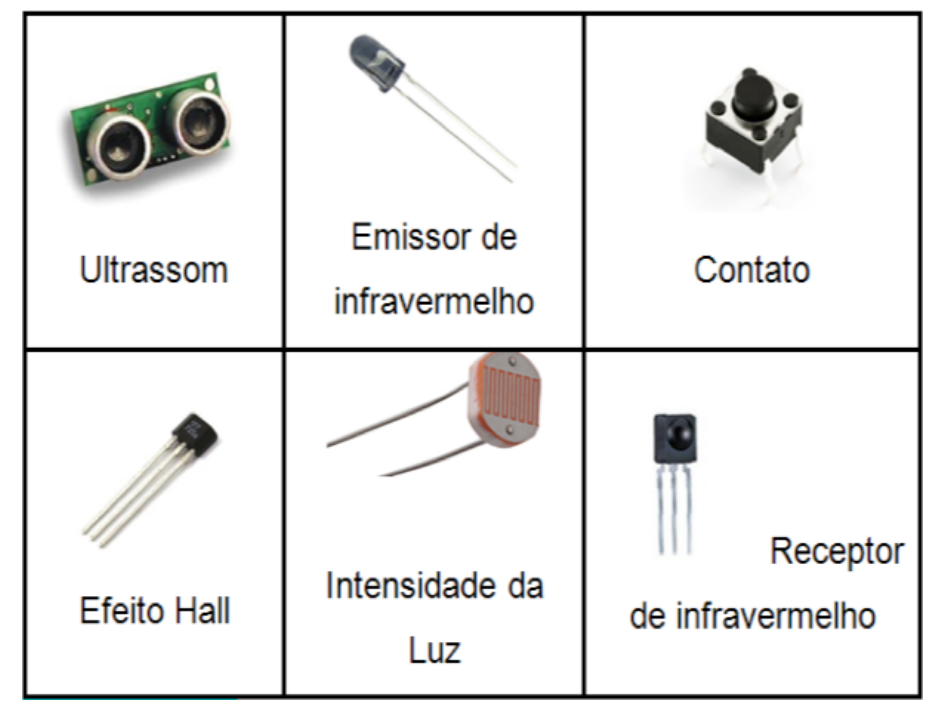

Figura 62 - Sensores que podem ser empregados na montagem da lombada eletrônica na OP didática via o Arduino.

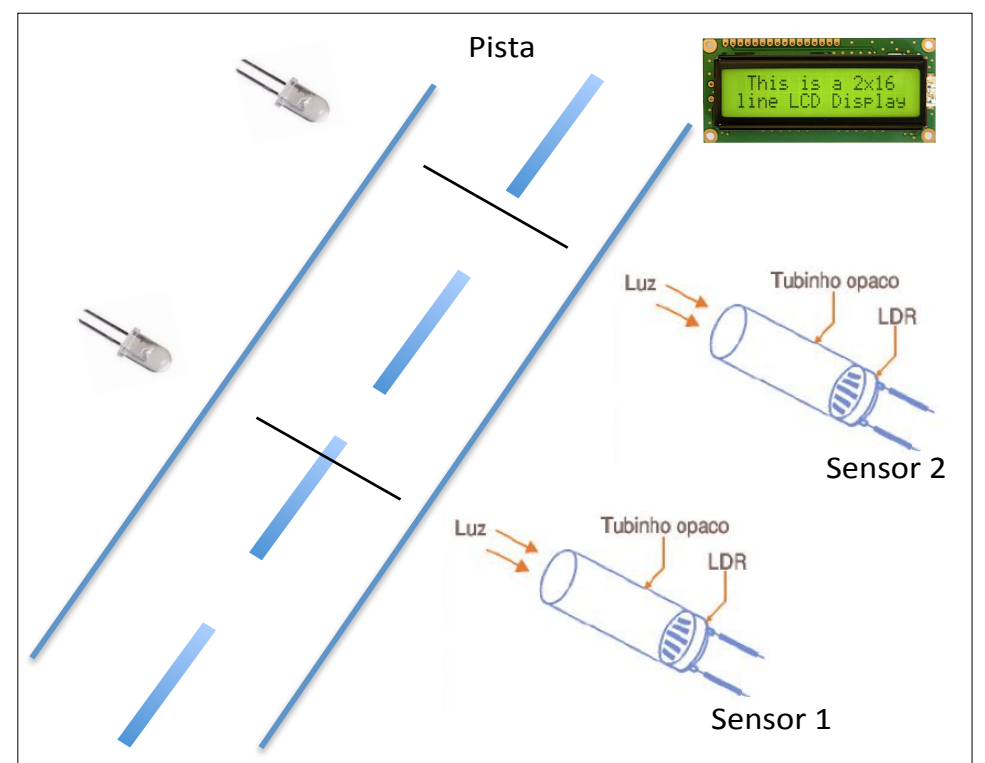

Figura 63 - Esquema da lombada eletrônica com sensor de luz, display de LCD e LEDs. Todas as informações são processadas pelo Arduino.

Para essa sugestão de montagem de uma lombada eletrônica, dentre os diferentes sensores comunicando-se com o Arduino, optamos por fazer uso de um sensor de intensidade de luz (LDR). A ideia principal é detectar o movimento de um carrinho e calcular sua velocidade. 
É interessante notar que outra técnica que auxilia na determinação da velocidade nessa OP didática envolve a utilização de um sensor de luz, responsável por enviar informações ao Arduino sobre o tempo de passagem do veículo entre uma faixa da pista e outra (nesse caso, entre os LDR). Sabendo a largura da faixa, calcula-se automaticamente a velocidade pelo Arduino previamente programado, a qual é exibida no display. Essa técnica de modo algum corresponde a OP de referência (lombada eletrônica que usa duas bobinas que geram campos magnéticos).

Por fim, nota-se ainda que os instrumentos oferecidos pela robótica educacional permitem modificar determinadas técnicas de tal modo aproximando-as ou distanciando-as da realidade que se deseja explorar. Assim, caso se tenha interesse em explorar na OP didática técnicas similares, ou seja, que utilizam variações do campos magnético para registrar o tempo de passagem do veículo entre um ponto e outro, poder-se-ia usar o sensor de efeito hall, o qual funciona como um transdutor que varia sua tensão de saída em resposta a um campo magnético externo. Isso pode aumentar o grau de liberdade e protagonismo do educando, permitindo que sua criatividade seja explorada sob diferentes aspectos na resolução dos problemas propostos, revisitando o mundo ao seu redor sob novas perspectivas e ampliando suas possibilidades de ação e compreensão. 


\section{CONSIDERAÇÕES FINAIS}

A habilidade mais determinante do padrão de vida de uma pessoa é a capacidade de aprender novas habilidades, assimilar novos conceitos, avaliar novas situações, lidar com o inesperado. Isso será cada vez mais verdadeiro no futuro: a habilidade para competir tornou-se a habilidade de aprender.

\section{Seymour Papert ${ }^{34}$}

Poder-se-á dizer, uma vez mais, que tudo isso requer tempo. Que não há tempo a perder, visto que existe um programa que deve ser cumprido. E, uma vez mais, em nome do tempo que não se deve perder, o que se faz é perder tempo, alienando-se a juventude com um tipo de pensamento formalista, com narrações quase sempre exclusivamente verbalistas. Narrações cujo conteúdo 'dado' deve ser passivamente recebido e memorizado para depois ser repetido.

Paulo Freire $^{35}$

A Teoria Antropológica do Didático mostrou-se como uma forte aliada na iniciativa em evidenciar melhor a estrutura e dinâmica entre os objetos de uma dada realidade (OP de referência) e os objetos da atividade didática (OP didática), especialmente em atividades que fazem uso de instrumentos da Robótica Educacional para gerar uma contextualização passando pela problematização e modelização. Isso foi feito em termos de tarefas, técnicas, tecnologias e teoria, nas quais se procurou explorar a relação do indivíduo (X) com os objetos (O) de uma determinada Organização Praxeológica (OP).

\footnotetext{
${ }^{34}$ In. A máquina das crianças: repensando a escolar na era da informática. Ed. rev. Porto Alegre: Artmed, 2008, p. 13.

${ }^{35}$ In. Extensão ou Comunicação? $3^{\text {a }}$ edição, Rio de Janeiro: Editora Paz e Terra, 1977, p. 53.
} 
Nessa perspectiva, o processo de contextualização no ensino de Física é considerado satisfatório quando, por meio da OP didática, o indivíduo $(\mathrm{X})$ for capaz de alterar ou criar relações $(\mathrm{R})$ com objetos $(\mathrm{O})$ contidos em uma Organização Praxeológica, $[\mathrm{R}(\mathrm{X}, \mathrm{O})]$, e/ou em múltiplas Organizações Praxeológicas, $\left[\mathrm{R}(\mathrm{X}, \mathrm{O}) \rightarrow \mathrm{R}\left(\mathrm{X}, \mathrm{O}_{\mathrm{n}}\right)\right]$.

A robótica educacional, especialmente quando voltada para o ensino de Física, permite uma vasta abordagem que pode englobar vários objetos de uma dada OP, porém, alertamos que isso apenas não é suficiente. Percebemos que, quando se visa estimular o aluno a refletir e interligar teoria e prática, os recursos oferecidos pela Robótica Educacional poderiam ser utilizados durante o processo de ensino e aprendizagem levando em consideração dois blocos, os quais necessitam estar muito bem interligados e trabalhados na atividade, o bloco práticotécnico e o tecnológico-teórico. É preciso evitar atividades vazias e "alienadas" especialmente aquelas de ordem prática. Deve-se estar atento ao saber-fazer, práxis, sem esquecer do discurso lógico que permeia e auxilia na compreensão desse saber-fazer, o logos.

Se não for identificada na OP didática a ocorrência do bloco tecnológico-teórico, ao menos uma parte dele (uma tecnologia, por exemplo), a modelização do conhecimento tão importante para o ensino de Física fica seriamente prejudicada. Se não existir na OP didática uma fração que seja do bloco tecnológico-teórico para melhor compreender as técnicas adotadas no cumprimento de determinas tarefas, principalmente daquelas apresentadas na problematização, a mobilização dos saberes disciplinares corre o risco de ficar incompleta ou até mesmo de não existir. Desse modo, a contextualização servirá apenas como mera ilustração ou exemplo de uma dada realidade, mas sem retorno a esta, além de dificultar que os educandos se confrontem com situações que lhe causem a necessidade de buscar e se apropriar de um conjunto de saberes que ainda não têm mas que é possível alcançar.

Novos recursos oferecidos pelas tecnologias estão cada vez mais presentes no cenário educacional. Por essa razão, torna-se necessário e pertinente a inclusão dessa discussão sobre possíveis estratégias para se analisar e desenvolver atividades didáticas nesse quadro. Reforçamos que nossa preocupação central nessa pesquisa não trata de imediato da aprendizagem propriamente dita via recursos oferecidos pela RE, mas sim, pretendemos buscar soluções e refletir sobre o desenvolvimento e estruturação de atividades didáticas para melhor contextualizar uma dada realidade, fornecendo norteadores para fomentar a problematização e guiar a modelização dos saberes disciplinares, os quais, por sua vez, assumem papel fundamental no processo de ensino e aprendizagem. 
Percebemos que a TAD, especialmente no que tange seu componente estrutural (Praxeologia), mostra-se como uma ferramenta teórica potencialmente adequada para entender os limites e possibilidades da robótica em situações que envolvam tarefas que demandem conhecimento específico de Física, especialmente para destacar os elementos praxeológicos que, de fato, são explorados na OP didática com ressonâncias nos fenômenos físicos e/ou na atividade humana que se deseja contextualizar, ou seja, com objetos de diferentes OP de referência.

Por fim, identificamos que podemos adotar a noção de VP para fomentar o planejamento e desenvolvimento de atividades didáticas contextualizadas. Ao invés de se utilizar o mapa conceitual para fomentar a análise da OP didática e de referência, pode-se desenvolver um mapa conceitual para investigar primeiramente a prática de referência e extrair quais tarefas, técnicas, tecnologias ou teorias se deseja tratar ou são mais viáveis para constar na atividade didática (seja por Verossimilhança Praxeológica de interseção e/ ou correspondência).

Encerramos essa tese com a continuação do diálogo (epígrafe de abertura) entre o computador "Pensador Profundo" e seus interlocutores, ávidos pela resposta para a Grande Pergunta! A Questão Fundamental da Vida, do Universo e Tudo o Mais...

- Mas você pode descobri-la? - perguntou Loonquawl. Pensador Profundo ponderou a questão por mais algum tempo.

- Não - respondeu por fim, com firmeza. Os dois homens caíram sentados, em desespero.

- Mas eu lhes digo quem pode - disse o computador. Os dois levantaram a vista de repente.

- Quem?

- Diga!

De repente, Arthur começou a sentir seus pelos inexistentes ficarem em pé à medida que ele se aproximava lenta porém inexoravelmente do terminal do computador, mas era apenas um zoom de grande efeito dramático por parte de quem havia realizado aquela gravação, aparentemente.

- Refiro-me ao computador que virá depois de mim - proclamou Pensador Profundo, resumindo seu tom declamatório habitual. - Um computador cujos parâmetros operacionais eu não sou digno de calcular, mas que, ainda sim, irei projetar para vocês. Um computador capaz de calcular a Pergunta referente à Resposta Fundamental, um computador de tamanha complexidade sutil e infinita que a própria vida orgânica fará parte de sua matriz operacional. E vocês assumirão uma nova forma e entrarão no computador para operar seu programa, durante dez milhões de anos! Sim! Eu projetarei este computador para vocês. E eu também lhe darei um nome. E ele se chamará... Terra. 


\section{REFERÊNCIAS BIBLIOGRÁFICAS}

ALIMISIS, Dimitris. Educational robotics: Open questions and new challenges. Themes in Science \& Technology Education, 6(1), 63-71, 2013.

ALLEN, D. E.; DONHAM, R.S.; BERHARDT, S. A. Problem-based learning. In: W. Buskist \& JE Groccia eds, Evidence-based teaching. New Directions for Teaching and Learning Winter 2011; 128:21-29.

ALVES FILHO, J. P. Atividades experimentais: do método à prática construtivista. Tese (Doutorado em Educação). Centro de Ciências da Educação, Universidade Federal de Santa Catarina, Florianópolis, 2000.

., Regras da transposição didática aplicadas ao laboratório didático. Caderno Catarinense de Ensino de Física, v. 17, n. 2, ago. 2000 b.

AMEM, Bernadete Malmegrim Vanzella; NUNES, Lena Cardoso. Tecnologias de Informação e Comunicação: contribuições para o processo interdisciplinar no ensino superior. Rev. bras. educ. med., Rio de Janeiro, v. 30, n. 3, Dec. 2006. http://dx.doi.org/10.1590/S0100-55022006000300008.

ANGOTTI. J. A.; DELIZOICOV, D. Metodologia do ensino de Ciências. 2a edição. São Paulo, Cortez, 2002.

ARANTES, A. R.; MIRANDA, M. S.; STUDART, N. Objetos de aprendizagem no ensino de física. Física na Escola, v. 11, n. 1, 2010.

ARAUJO, I. S.; VEIT, E. A.; MOREIRA, M. A., Uma revisão da literatura sobre estudos relativos a tecnologias computacionais no ensino de Física. Revista Brasileira de Pesquisa em Educação em Ciências, 2004.

AROCA, R. V. Plataforma robótica de baixíssimo custo para robótica educacional. Tese (Doutorado) - Universidade Federal do Rio Grande do Norte. Centro de Tecnologia. Programa de Pós-Graduação em Engenharia Elétrica e de Computação, 2012.

ARROIO, A.; FARÍAS, D. Possible contributions of Cinema in Natural Science Education to understand how scientists and Science works. Problems of Education in the 21st Century, 37, 18-28, 2011.

ARROIO, A. Context based learning: a role for cinema in science education. Science Education International, 21(3), 131-143, 2010.

ASTOLFI, Jean-Pierre; DELEVAY, M., A didática das ciências. Magda S.S. Fonseca (tradução). Campinas, SP. Editora Papirus, 2001. ISBN 85-308-0116-4.

AULETE. Dicionário da língua portuguesa. Versão online, 2014. Disponível em http://aulete.uol.com.br Acesso em 4 de março de 2014.

BACHELARD, Gaston. O racionalismo aplicado. Rio de Janeiro: Zahar, 1977. 
BALDINATO, José Otavio. A química segundo Michael Faraday: Um caso de divulgação científica no século XIX. 2009. Dissertação (Mestrado em Ensino de Química) - Ensino de Ciências (Física, Química e Biologia), Universidade de São Paulo, São Paulo, 2009. Disponível em: $\quad<$ http://www.teses.usp.br/teses/disponiveis/81/81132/tde-22022011115911/>. Acesso em: 2014-05-28.

BARBÉ, J.; BOSCH, M.; ESPINOZA, L.; GASCÓN, J., Didactic Restrictions on the Teacher's Practice: The Case of Limits of Functions in Spanish High Schools. Educational Studies in Mathematics. v. 59, n. 1-3, pp. 235-268, 2005.

BARAK, M., ZADOK, Y., Robotics projects and learning concepts in science, technology and problem solving. International Journal of Technology and Design Education, v. 19, n. 3, pp. 289-307, 2009.

BARBOSA, H. M.; et al., Sistema de identificação de veículos por meio de laços de indução: um projeto integrado de ensino e desenvolvimento tecnológico. In. Congresso de Pesquisa e Ensino em Transportes. Florianópolis - SC. Atas do XVIII ANPET, 2004.

BARRA, V. M. e LORENZ, K. M. Produção de materiais didáticos de Ciências no Brasil, período: 1950-1980. Ciência e Cultura, São Paulo, v. 38, n. 12, p. 1970-83, dezembro de 1986.

BASTOS FILHO, J. B., O que se deve exigir, tendo em vista que não há panacéias para o ensino de física? In: Encontro de Física do Norte e Nordeste - EFNNE, 2006, João Pessoa. Livro de resumos do XXIV EFNNE, vol. único, 2006.

BENITTI, F. B. V., Exploring the educational potential of robotics in schools: A systematic review. Computers \& Education (58), 2012.

BERBEL, Neusi Aparecida Navas. A problematização e a aprendizagem baseada em problemas: diferentes termos ou diferentes caminhos?. Interface (Botucatu), Botucatu , v. 2, n. 2, Feb. 1998. http://dx.doi.org/10.1590/S1414-32831998000100008.

BERTI, Valdir Pedro. Interdisciplinaridade: um conceito polissêmico. 2007. Dissertação (Mestrado em Ensino de Química) - Ensino de Ciências (Física, Química e Biologia), Universidade de São Paulo, São Paulo, 2007. Disponível em: $<$ http://www.teses.usp.br/teses/disponiveis/81/81132/tde-07052013-145350/>. Acesso em: 2014-02-04.

BOSCH, M., CHEVALLARD, Y., GASCÓN, J., Science of Magic? The use of models and theories in didactics of mathematics. In Bosch, M. Proceedings of the 4th Conference of the European Research in Mathematics Education, CERME, BARCELONA, 2006.

BOSCH, M., et al., CRM Documents - Un panorama de la TAD / An overview of ATD. 1ed. Barcelona: CRM Centre de Recerca Matemática 10, p. 203-216, 2011.

BROCKINGTON, G.; LAPIN, M. A. F.; SIQUEIRA, M.; SCHIVANI, M. Informatique dans 1 Enseignement des Sciences: la proposition d un cours de Physique en utilisant des environnement interactives en réalité virtuelle. In: Les 29es Journées Internationales sur la Communication, l'Éducation et la Culture Scientifiques et Industrielles, Chamonix, 2008. 
BROUSSEAU, G., Theory of Didactical Situations in Mathematics. Didactique des mathématiques, 1970-1990, in N. Balacheff, M. Cooper, R. Sutherland, V. Warfield (eds.), Dordrecht: Kluwer Academic Publishers, 1997.

BRASIL., Diretrizes curriculares nacionais para o ensino médio. Ministério da Educação (MEC). Conselho Nacional de Educação. Brasília: MEC/CNE, 1998.

., PCN Ensino médio. Parâmetros Curriculares Nacionais para o Ensino Médio Parte II - Linguagens, Códigos e suas Tecnologias. Ministério da Educação (MEC), Secretaria de Educação Média e Tecnológica (Semtec). Brasília: MEC/Semtec, 2000.

., PCN + Ensino médio: orientações educacionais complementares aos Parâmetros Curriculares Nacionais - Ciências da Natureza, Matemática e suas Tecnologias. Ministério da Educação (MEC), Secretaria de Educação Média e Tecnológica (Semtec). Brasília: MEC/Semtec, 2002.

., Orientações curriculares para o ensino médio. Volume 2 - Ciências da natureza, matemática e suas tecnologias. Secretaria de Educação Básica. - Brasília : Ministério da Educação (MEC), Secretaria de Educação Básica, 2006.

BYBEE, R. W.; Reflecting on Sputnik: Linking the Past, Present, and Future of Educational Reform. Washington, 1997. Disponível em http://www.nas.edu/sputnik/bybee1.htm Acesso em 4 de março de 2014.

BYBEE, R. W., \& FUCHS, B.; Preparing the 21st century workforce: A new reform in science and technology education. Journal of Research in Science Teaching, V. 43(4), 349352, 2006.

CABRAL, C. P., Robótica educacional e resolução de problemas: uma abordagem microgenética da construção do conhecimento. Dissertação (Mestrado). Faculdade de Educação da UFRGS - Porto Alegre - RS, 2011.

CARVAlHO, A. M. P de; O Ensino de Física na Grande São Paulo: Estudo de um Processo em Transformação. Tese (Doutorado). Faculdade de Educação da Universidade de São Paulo - FEUSP, 1973.

CARVALHO, A. M. P de; VANNUCCHI, A., O currículo de física: inovações e tendências nos anos noventa. Investigações em Ensino de Ciências - V1(1), pp.3-19, 1996.

CARVALHO, C. C. S., Uma análise praxeológica das tarefas de prova e demonstração em tópicos de álgebra abordados no primeiro ano do Ensino Médio. Mestrado em Educação Matemática, Pontifícia Universidade Católica de São Paulo, PUC-SP, 2007.

CARVALHO, Maria Gomes de., Tecnologia, desenvolvimento social e educação tecnológica. In: Revista Educação \& Tecnologia. Curitiba: Centro Federal de Educação Tecnológica do Paraná, jul.1997.

CAVAlCANTE, M. A.; TAVOLARO, C. R. C.; MOLISANI, E., Física com Arduino para iniciantes. Rev. Bras. Ensino Fís., São Paulo, v. 33, n. 4, Dec. 2011. 
http://dx.doi.org/10.1590/S1806-11172011000400018.

CÉSAR, Danilo R., Robótica Pedagógica Livre: uma Alternativa Metodológica para a Emancipação Sociodigital e a Democratização do Conhecimento. Universidade Federal da Bahia. Tese (Doutorado). Programa de pós-graduação em Difusão do Conhecimento, 2013.

CÉSAR, Danilo R., Potencialidades e Limites da Robótica Pedagógica Livre no Processo de (Re)construção de Conceitos Científico-Tecnológicos a partir do Desenvolvimento de Artefatos Robóticos. Universidade Federal da Bahia. Dissertação (Mestrado). Programa de pós-graduação em Educação, 2009.

CHALMERS, C., et al., Prospective teachers teaching technology and building aspirations with robotics. In. Going for Gold! Reshaping teacher education for the future, Australian Teacher Education Association (ATEA), Adelaide, S. Aust. (In Press), 2012.

CHEVALLARD, Y., La transposition didactique. Du savoir savant au savoir enseigné, Grenoble: La Pensée Sauvage, 1985.

, Fundamentals concepts of didactics: perspectives given by an anthropological approach. Recherches en Didactique des Mathématiques 17(3), 17-54, 1992.

, El análisis de las prácticas docentes en la teoría antropológica de lo didáctico. Recherches en Didactique des Mathématiques, v. 19, n. 2, pp. 221-266. [Tradução de Ricardo Barroso Campos], 1999. Disponível em: http://www.cienciamia.com.mx/fised/02mie/lecturas/El_analisis_de_las_practicas_docentes_e n_la_teoria_antropologica_de_los_didactico.pdf Acesso em 6 de novembro de 2013.

, L'analyse des pratiques enseignantes en théorie anthropologique du didactique. Recherches en didactique des mathématiques (Revue), Pensée sauvage 19, [2], 221-265, 1999b.

, Approche anthropologique du rapport au savoir et didactique des mathematiques. IUFM d' Aix-Marseille, 2006. Disponível em

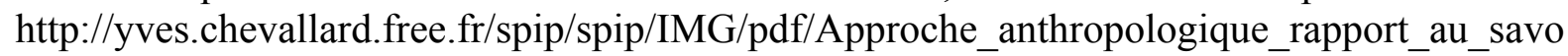
ir.pdf Acesso em 02 de março de 2014.

CHEVALLARD, Y., BOSCH, M., GASCÓN, J., Estudiar matemáticas. El eslabón perdido entre la enseñanza y el aprendizaje, Barcelona: ICE/Horsori, 1997.

CHURCH, W.; FORD, T.; PEROVA, N.; ROGERS, C., Physics with robotics: Using LEGO ${ }^{\circledR}$ MINDSTORMS ${ }^{\circledR}$ in high school education. Paper presented at the Association for the Advancement of Artificial Intelligence. Spring Symposium Series, Stanford University, 2010 .

COLUCI, Vitor R. et al., Ilustração de incertezas em medidas utilizando experimentos de queda livre. Rev. Bras. Ensino Fís., São Paulo, v. 35, n. 2, June, 2013. http://dx.doi.org/10.1590/S1806-11172013000200026.

COMISSÃO EUROPEIA. O Ensino das Ciências na Europa: Políticas Nacionais, Práticas e Investigação. Agência Executiva relativa à Educação, ao Audiovisual e à Cultura - EACEA 
CORREIA, P. R. M.; SILVA, A. C. da.; JUNIOR, J. G. R., Mapas conceituais como ferramenta de avaliação na sala de aula. Revista Brasileira de Ensino de Física, v. 32, n. 4, 2010 .

CRUZ, E. S., A noção de variável em livros didáticos de Ensino Fundamental; um estudo sob a ótica da organização praxeológica. Mestrado em Educação Matemática, Pontifícia Universidade Católica de São Paulo, PUC-SP, 2005.

CRUZ-MARTÍN, A., et al., A LEGO Mindstorms NXT approach for teaching at Data Acquisition, Control Systems Engineering and Real-Time Systems undergraduate courses. Computers \& Education 59, 974-988, 2012.

CYRINO, Eliana G.; TORALLES-PEREIRA, Maria L., Trabalhando com estratégias de ensino-aprendizado por descoberta na área da saúde: a problematização e a aprendizagem baseada em problemas. Cad. Saúde Pública, Rio de Janeiro , v. 20, n. 3, June 2004. http://dx.doi.org/10.1590/S0102-311X2004000300015.

D'ABREU, J. V. V., Desenvolvimento de ambientes de aprendizagem baseados no uso de dispositivos robóticos. SIMPÓSIO BRASILEIRO DE INFORMÁTICA NA EDUCAÇÃO SBIE99, 11., 1999, Curitiba. Anais... Curitiba, PR: UFPR, 1999.

D'ABREU, J. V. V.; et al [org]., Tecnologias e mídias interativas na escola: Projeto TIME. Campinas, SP: UNICAMP/NIED, pp. 1-424, 2010. ISBN:978-85-88833-06-7.

DeBOER, G. E., Scientific literacy: Another look at its historical and contemporary meanings and its relationship to science education reform. J. Res. Sci. Teach., 37: 582-601, 2000.

DELIZOICOV, D., Problemas e Problematizações. In. Ensino de Física: conteúdo, metodologia e epistemologia em uma concepção integradora. Maurício Pietrocola (org). Editora UFSC, $2^{\mathrm{a}}$ edição, Florianópolis, 2005.

, Conhecimento, tensões e transições. Tese (Doutorado). Faculdade de Educação da Universidade de São Paulo - FESUP, 1991.

DIOGO, R. C.; OSÓRIO, A. S.; SILVA, D. R. R., A Teoria Antropológica do Didático: Possibilidades de Contribuição ao Ensino de Física. In: VI Encontro Nacional de Pesquisa em Educação em Ciências, Florianópolis/SC, 2007.

EIJCK, M., Capturing the Dynamics of Science in Science Education. In. B.J. Fraser et al. (eds.), Second International Handbook of Science Education, Springer International Handbooks of Education v. 24, pp. 1029-1039, 2012.

EUROPEAN COMMUNITIES. Science Education Now: A Renewed Pedagogy for the Future of Europe. Luxembourg: Office for Official Publications of the European Communities, 2007.

FILOCRE, J.; GOMES, A. E. Q.; BORGES, O. N., Modelos de capacitação de professores implementados pelo CECIMIG/UFMG. In: V Encontro de Pesquisadores em Ensino de Física 
- VEPEF. Águas de Lindóia, pp. 296-310, 1996.

FIOLHAIS, C.; TRINDADE, J., Física no computador: o computador como uma ferramenta no ensino e na aprendizagem das ciências físicas. Rev. Bras. Ensino Fís., São Paulo , v. 25, n. 3, Sept. 2003. http://dx.doi.org/10.1590/S1806-11172003000300002.

FERNANDES, Carolina dos S., MARQUES, Calos A., A contextualização no ensino de ciências: a voz de elaboradores de textos teóricos e metodológicos do exame nacional do ensino médio. Investigações em Ensino de Ciências - v.17(2), pp. 509-527, 2012.

FERNANDES, C. C.; SÁ, S. T.; GONÇALVES, L. M., Uma nova abordagem em robótica educacional utilizando simuladores e kits de robótica livre. In. III Workshop de Robótica Educacional. Natal, RN, 2012.

FLL. FIRST LEGO League, 2014. Disponível em: $<$ http://www.firstlegoleague.org $>$. Acesso em: 04 Mai. 2014.

FORATO, Thaís C. M., A natureza da ciência como saber escolar: um estudo de caso a partir da história da luz. Tese (Doutorado). Faculdade de Educação da Universidade de São Paulo FEUSP, 2009.

FOUREZ, G., Crise no ensino de ciências? Investigações em Ensino de Ciências - V8(2), pp. 109-123, 2003.

FRANGOU, S. et al., Representative examples of implementing educational robotics in school based on the constructivist approach. In: Workshop Proceedings of SIMPAR. ISBN 978-88-95872-01-8. Venice (Italy), November, 3-4, p. 54-68, 2008.

FREIRE, P., Extensão ou comunicação? $3^{\text {a }}$ edição, Rio de Janeiro: Editora Paz e Terra, 1977.

, Pedagogia da autonomia: saberes necessários à prática educativa. $36^{\mathrm{a}}$ edição, São Paulo: Paz e Terra, 2007.

À Sombra desta Mangueira. $8^{\mathrm{a}}$ edição. Editora OLHO d'água, São Paulo, 2006. ISBN 85-85428-15-5.

GIORDAN, M., Uma perspective sociocultural para os estudos sobre elaboração de significados em situações de uso do computador na Educação em Ciências. Livre-docência. FEUSP, Universidade de São Paulo (USP), 2006.

GOMES, R.; et al., Aprendizagem Baseada em Problemas na formação médica e o currículo tradicional de Medicina: uma revisão bibliográfica. Rev. bras. educ. med., Rio de Janeiro, v. 33, n. 3, Sept. 2009. http://dx.doi.org/10.1590/S0100-55022009000300014.

GONÇALVES, P. C., Protótipo de um robô móvel de baixo custo para uso educacional. Dissertação (Mestrado em Ciência da Computação), Universidade Estadual de Maringá, 2007.

GRECA, I. M.; SANTOS, F. M. T., Dificuldades da generalização das estratégias de modelação em Ciências: o caso da Física e da Química. Investigações em Ensino de Ciências, Porto Alegre, v. 10, n. 1, 2005. 
GREF. Grupo de Reelaboração do Ensino de Física. Física 1. São Paulo: Edusp, 1990.

JESUS, V.L.B. de; MARLASCA, C. \& TENORIO, A., Ludião versus princípio do submarino. Rev. Bras. Ensino Fís. [online]. 2007, vol.29, n.4, pp. 599-603. ISSN 1806-1117. http://dx.doi.org/10.1590/S1806-11172007000400019.

JUCÁ, S. C. S., A relevância dos softwares educativos na educação profissional. Ciências e Cognição, v. 8, 2011.

JÚNIOR, N. M. F.; VASQUES, C. K.; FRANCISCO, T. H. A., Robótica educacional e a produção científica na base de dados da CAPES. Revista Electrónica de Investigación y Docencia (REID), 4, Julio, 2010.

KARAM, R. A. S., Estruturação matemática do pensamento físico no ensino: uma ferramenta teórica para analisar abordagens didáticas. 2012. Tese (Doutorado em Educação) - Faculdade de Educação, Universidade de São Paulo, São Paulo, 2012. Disponível em: $<$ http://www.teses.usp.br/teses/disponiveis/48/48134/tde-29052012-134910/>. Acesso em: 2014-03-08.

KATO, D. S.; KAWASAKI, C. S., As concepções de contextualização do ensino em documentos curriculares oficiais e de professores de ciências. Ciência \& Educação (Bauru), vol. 17 (1) p. 35-50, 2011.

KENSKI, Vani M., Tecnologias e ensino presencial e a distância. Campinas, SP: Papirus, 2003. ISBN 85-3-8-0708-1.

KRASILCHIK, M., Reformas e realidade: o caso do ensino das ciências. São Paulo Perspec., São Paulo , v. 14, n. 1, Mar. 2000. http://dx.doi.org/10.1590/S010288392000000100010 .

KUHN, T. S., A estrutura das revoluções científicas. Tradução: Beatriz Vianna Boeira \& Nelson Boeira. $9^{\mathrm{a}}$ edição, $1^{\mathrm{a}}$ reimpressão. São Paulo: Perspectiva, 2007. , O professor e o currículo das ciências. São Paulo, EPU/Edusp, 1987.

LIANG-YI, Li et al., Researches on Using Robots in Education. In. Learning by playing. Game-based education system design and development. Lecture Notes in Computer Science, Volume 5670, 2009.

LIMA, J. R. T de.; PIRES, R. M.; ARAUJO, A. E. P. de., Robótica pedagógica para o ensino de física sob um olhar da teoria Kellyana. In. Simpósio Nacional de Ensino de Física - SNEF. Manaus - AM. Atas do XIX SNEF, 2011.

LONGHINI, M. D.; MENEZES, L. D. de Deus., Objeto virtual de aprendizagem no ensino de Astronomia: Algumas situações problemas propostas a partir do software Stellarium. Caderno Brasileiro de Ensino de Física, [S.1.], v. 27, n. 3, p. 433-448, Mar. 2011. doi: 10.5007/21757941.2010v27n3p433.

LOPES, A. C., Os parâmetros curriculares nacionais para o ensino médio e a submissão ao 
mundo produtivo: o caso do conceito de contextualização. Educação \& Sociedade, Campinas, v. 23, n. 80, p. 386-400, 2002.

LOPES, A. C.; GOMES, M. M.; LIMA, I. dos S., Diferentes contextos na área de ciências da natureza, matemática e suas tecnologias dos parâmetros curriculares nacionais do ensino médio: integração com base no mercado. In. Encontro Nacional de Pesquisa em Ensino de Ciências (ENEPC). Atas do III ENPEC, Atibaia - SP, 2001.

LORENZ, Karl M., Ação de instituições estrangeiras e nacionais no desenvolvimento de materiais didáticos de ciências no Brasil: 1960-1980. Revista Educação em Questão, Natal, v. 31, n. 17, p. 7-23, jan./abr. 2008.

LOWE, M.; MOORE, H.; LANGRALL, E.; GEHRMAN, C., Robots in the introductory physics laboratory. American Association of Physics Teachers, v. 76, n. 10, p. 895-902, 2008.

LUND, H. H. \& PAGLIARINI, L., Robot Soccer with LEGO Mindstorms. In. M. Asada, H. Kitano (Eds.): RoboCup-98, LNAI 1604, pp. 141-151, 1999. DOI: 10.1007/3-540-48422111 .

MACHADO, N. J., Interdisciplinaridade e contextuação. In: Ministério da Educação, Instituto Nacional de Estudos e Pesquisas Educacionais Anísio Teixeira. Exame Nacional do Ensino Médio (ENEM): fundamentação teórico-metodológica. Brasília: MEC; INEP, p. 41-53, 2005.

MADDOX, J., The Nuffield Physics Project. Physics Education, vol. 1 (1), 1966. doi:10.1088/0031-9120/1/1/301.

MADSEN, L.; WINSLOW, C., Relations between teaching and research in physical geography and mathematics at research-intensive universities. International Journal of Science and Mathematics Education 7, p. 741-763, 2009.

MARANDINO, M. ; MORTENSEN, M., Museographic transposition: accomplishments and applications. In: Bosch, M. et al (Org.). CRM Documents - Un panorama de la TAD/An overview of ATD. 1ed. Barcelona: CRM Centre de Recerca Matemática 10, p. 203-216, 2011.

MARTINAND, Jean-Louis., Pratiques sociales de référence et compétences techniques. À propos d'un projet d'initiation aux techniques de fabrication mécanique en classe de quatrième. In A. Giordan, J.-L. Martinand (Éds.), Diffusion et appropriation du savoir scientifique : enseignement et vulgarisation, Actes des troisièmes Journées internationales sur l'éducation scientifique, pp. 149-154, 1981. Paris : UER Didactique, Uni. Paris 7. Consulté le 27 avril 2014, sur ARTheque - STEF - ENS Cachan, http://artheque.enscachan.fr/items/show/927.

, La question de la référence en didactique du curriculum. Investigações em Ensino de Ciências - V8(2), pp. 125-130, 2003.

MARTINHO, T.; POMBO, L., Potencialidades das TIC no ensino das Ciências Naturais: um estudo de caso. Revista Electrónica de Enseñanza de las Ciencias Vol.8 N.2, 2009.

MATTHEWS, M. R., Historia, filosofía y enseñanza de las ciencias: la aproximación actual, Enseñanza de las Ciencias. 12(2), p. 255-277, 1994. 
MAYBURY, Robert H., Technical assistance and innovation in science education. New York: John Wiley \& Sons, 1975.

MEIRIEU, P., Aprender... sim, mas como? Tradução de Vanise Pereira Dresch; consultoria de Maria da Graça Souza Horn e Heloísa Schaan Solassi. 7. ed. Porto Alegre: Artmed, 1998.

MELO, W. C., Uso do jornal no ensino de Física. Dissertação (Mestrado). Instituto de Física da Universidade de São Paulo - IFUSP, 2006.

MIRANDA JUNIOR, M. R., Introdução ao uso da informática no Ensino Médio. Dissertação (Mestrado). Instituto de Física da Universidade Federal do Rio Grande do Sul - IF-UFRGS. Porto Alegre, 2005.

MIRANDA, L. C.; SAMPAIO, F. F.; BORGES, J. A. S., RoboFácil: Especificação e Implementação de um Kit de Robótica para a Realidade Educacional Brasileira, 2010. ISSN: $1414-5685$.

MITNIK, R.; RECABARREN, M.; NUSSBAUM, M.; SOTO, A., Collaborative robotic instruction: A graph teaching experience. Computers \& Education, v. 53, n.2, 2009.

MOREIRA, M. A., Ensino de Física no Brasil: Retrospectiva e Perspectivas . Revista Brasileira de Ensino de Física, vol. 22, N. 1, março, 2000.

MORELATO, L. A. ; NASCIMENTO, R. A. O. ; d'ABREU, J. V. V. ; BORGES, M. A. F., Avaliando Diferentes Possibilidades de Uso da Robótica Pedagógica na Educação. Revista de Ensino de Ciências e Matemática - REnCiMa, v. 01, p. 80-96, 2010.

MORTENSEN, Marianne F., Analysis of the Educational Potential of a Science Museum Learning Environment: Visitors' experience with and understanding of an immersion exhibit. International Journal of Science Education, 33(4), pp. 517-545, 2010.

NARDI, R., Memórias da educação em ciências no Brasil: a pesquisa em ensino de física. Investigações em Ensino de Ciências - V10(1), pp. 63-101, 2005.

NEVILLE, Alan J., Problem-based learning and medical education forty years on. A review of its effects on knowledge and clinical performance. Medical Principles and Practice, 18:1-9, 2009. DOI: $10.1159 / 000163038$.

NEWMAN, Mark J., Problem Based Learning: an introduction and overview of the key features of the approach. J Vet Med Educ. 32(1):12-20, 2005.

NIKITINA, S., Three strategies for interdisciplinary teaching: contextualizing, conceptualizing, and problem-centring. Journal of Curriculum Studies, 2006, vol. 38, n. 3, 251-271. http://dx.doi.org/10.1080/00220270500422632.

NOGUEIRA, Rosane C. S., A álgebra nos livros didáticos do ensino fundamental: uma análise praxeológica. Dissertação (mestrado) - Universidade Federal de Mato Grosso do Sul. Centro de Ciências Humanas e Sociais, 2008. 
NOGUEIRA, J. S.; RINALDI, C.; FERREIRA, J. M.; DE PAULO, S. R., Utilização do computador como instrumento de ensino: uma perspectiva de aprendizagem significativa. Rev. Bras. Ens. Fís., 22 (4): 517-522, 2000.

NOVAK, J. D.; MUSONDA, D., A twelve-year longitudinal study of science concept learning. American Educational Research Journal, v. 28, n. 1, p. 117-153, 1991.

NOVAK, J. D., CAÑAS, A. J., The Universality and Ubiquitousness of Concept Maps. In. Concept Maps: Making Learning Meaningful. Proc. of Fourth Int. Conference on Concept Mapping. Viña del Mar, Chile, 2010.

, The Theory Underlying Concept Maps and How to Construct and Use Them. Technical Report IHMC 2006-01 Rev 01-2008. Pensacola, FL: Institute for Human and Machine Cognition, 2008.

ODORICO, A., Marco teórico para una robótica pedagógica. Revista de Informática Educativa y Medios Audiovisuales Vol. 1(3), págs. 34-46, 2004.

OECD (Organisation for Economic Co-operation and Development). PISA 2012 Results in Focus: What 15-year-olds know and what they can do with what they know. OECD Publishing, 2012. Disponível em http://www.oecd.org/pisa/keyfindings/ Acesso em 02 de março de 2014.

, PISA 2009 Results: What Students Know and Can Do: Student Performance in Reading, Mathematics and Science. OECD Publishing, 2010.

OECD, Paris, 2007.

PISA 2006: science competencies for tomorrow's world, volume I analysis.

OLIVEIRA, Bernado J.; FREIRE JUNIOR, Olival., Uma conversa com Gerald Holton. Caderno Brasileiro de Ensino de Física, v. 23, n. 3: p. 315-328, dez. 2006.

OLIVEIRA, A. A. de., Física e ficção científica: desvelando mitos culturais em uma educação para a liberdade. Dissertação (Mestrado). Instituto de Física da Universidade de São Paulo IFUSP, 2011.

PACCA, Jesuina L. de A., Análise do desempenho de alunos frente a objetivos do Projeto de Ensino de Física. Dissertação (Mestrado). Instituto de Física da Universidade de São Paulo, 1977.

PAPERT, S., A Máquina das Crianças: repensando a escola na era da informática. Tradução: Sandra Costa. - ed. rev. - Porto Alegre: Artmed, 2008.

BasicBooks, 1980.

Mindstorms: Children, Computers and Powerful Ideas. New York:

PEDUZZI, L. O. Q., Sobre a resolução de problemas no ensino da física. Caderno Catarinense de Ensino de Física, 14 (3), 229-253, 1997.

PENA, F. L. A., Sobre a presença do Projeto Harvard no sistema educacional brasileiro. Rev. 
Bras. Ensino Fís., São Paulo , v. 34, n. 1, Mar. 2012. http://dx.doi.org/10.1590/S180611172012000100016.

PENA, F. L. A.; RIBEIRO FILHO, A., Obstáculos para o uso da experimentação no ensino de física: um estudo a partir de relatos de experiências pedagógicas brasileiras publicados em periódicos nacionais da área (1971-2006). Revista Brasileira de Pesquisa em Educação em Ciências, Belo Horizonte, v. 9, n. 1, p. 1-13, 2009. Disponível em: $<$ http://revistas.if.usp.br/rbpec/article/download/37/33ý> . Acesso em: 28 jan. 2014.

PÉREZ, D. Gil.; et al., Questionando a didática de resolução de problemas: elaboração de um modelo alternativo. Cad.Cat.Ens.Fís., Florianópolis, v.9,n.1: p.7-19, abr.1992.

PIASSI, L. P. C., A ficção científica no ensino de ciências em um contexto sociocultural. Tese (Doutorado). Faculdade de Educação da Universidade de São Paulo - FEUSP, 2007.

PIETROCOLA, M.; et al., Fascículo de Educação para a Vida ZOOM: ensino médio, $2^{\circ}$ ano: manual do professor. vol. 2, Curitiba, PR. ZOOM Editora Educacional, 2010. ISBN 978-857919-270-8.

, Fascículo de Educação para a Vida ZOOM: ensino médio, $1^{\circ}$ ano: manual do professor. vol. 1 , Curitiba, PR. ZOOM Editora Educacional, 2010b. ISBN 978-857919-133-6.

, Fascículo de Educação para a Vida Zoom: ENERGIA E POTÊNCIA - ensino médio, $1^{\circ}$ ano. vol. 3, Curitiba - PR : Zoom Editora Educacional, 2010c. ISBN: 97885-7919-063-6.

, Fascículo de Educação para a Vida Zoom: MÁQUINAS E EQUILÍBRIO - ensino médio, $1^{\mathrm{o}}$ ano. vol. 4, Curitiba - PR : Zoom Editora Educacional, 2010d, v.4. p.68. ISBN: 978-85-7919-062-9.

POPPER, Karl R., A lógica da pesquisa científica. Editora CULTRIX, 2ed., 2013. ISBN: 8531612500.

PSSC. Physical Science Study Committee, Física - Parte I. Instituto Brasileiro de Educação, Ciência e Cultura (IBECC), Editora Universidade de Brasília, 1963.

RICARDO, E. C., Problematização e contextualização no ensino de Física. In. Ensino de Física. Coleção ideias em ação. Anna Maria Pessoa de Carvalho (org.). São Paulo: Cengage Learning, 2010. ISBN 978-85-221-1062-9.

RICARDO, E., Competências, Interdisciplinaridade e Contextualização: dos Parâmetros Curriculares Nacionais a uma compreensão para o ensino das ciências. Tese (Doutorado). Programa de Pós-Graduação em Educação Científica e Tecnológica da Universidade Federal de Santa Catarina, pp. 1-257, 2005.

RIGDEN, John S.; STUEWER, Roger H., PSSC Physics, Eisenhower, and Today, 50 Years Later. Physics in Perspective (PIP), vol. 8, 2006. DOI:10.1007/s00016-006-0283-5.

ROSSINI, R., Saberes docentes sobre o tema função: uma investigação das praxeologias. 
Tese (Doutorado). Pontifícia Universidade Católica de São Paulo, PUC/SP, 2006.

ROUXINOL, Estevam.; et al., Novas tecnologias para o ensino de física: um estudo preliminar das características e potencialidades de atividades usando kits de robótica. In. Simpósio Nacional de Ensino de Física - SNEF, Manaus - AM. Atas do XIX SNEF, 2011.

ROYAL INSTITUTION. Royal Institution - Science Live Here. Disponível em http://www.rigb.org Acesso em 28 de maio de 2014.

RUDOLPH, John L., PSSC in Historical Context: Science, National Security, and American Culture during the Cold War. PSSC: 50 Years Later. American Association of Physics Teachers, 2006. Disponível em http://www.compadre.org/portal/pssc/pssc.cfm Acesso em $05 / 02 / 2014$.

RUIZ-DEL-SOLAR, J. \& AVILÉS, R., Robotics courses for children as a motivation tool: the Chilean experience. IEEE Transactions on Education, Vol. 47, N. 4, Nov. 2004.

SALEM, S., Perfil, evolução e perspectivas da pesquisa em ensino de física no Brasil. 2012. Tese (Doutorado em Ensino de Física) - Ensino de Ciências (Física, Química e Biologia), Universidade de São Paulo, São Paulo, 2012.

SANTOS, F.; NASCIMENTO, F.; MARTINS, R., Reduc: A robótica educacional como abordagem de baixo custo para o ensino de computação em cursos técnicos e tecnológicos. Anais do XVI Workshop Sobre Informática na Escola - XVIWIE, 2010. http://www.cbie.org.br/WIE2010/.

SANTOS, Wildson L. P. dos., MORTIMER, Eduardo F., A dimensão social do ensino de Química: um estudo exploratório da visão de professores. In. Encontro Nacional de Pesquisa em Educação em Ciências - ENPEC, Atas do II ENPEC, 1999.

SANTOS, Wildson L. P. dos., Educação científica humanística em uma perspectiva Freireana: resgatando a função do ensino de CTS. Alexandria Revista de Educação em Ciência e Tecnologia, v.1, n.1, p. 109-131, março de 2008.

SANTOS, Wildson L. P. dos., PORTO, Paulo A., A pesquisa em Ensino de Química como área estratégica para o desenvolvimento da Química. Quím. Nova, São Paulo , v. 36, n. 10, 2013 . http://dx.doi.org/10.1590/S0100-40422013001000014.

SAVERY, John R., Overview of problem-based learning: Definitions and distinctions. Interdisciplinary Journal of Problem-based Learning, 1(1), 2006. Available at: http://dx.doi.org/10.7771/1541-5015.1002.

SAWYER, R. K., Educating for innovation, Thinking Skills and Creativity, Volume 1, Issue 1, April 2006, Pages 41-48, ISSN 1871-1871, http://dx.doi.org/10.1016/j.tsc.2005.08.001.

SCHIVANI, M.; BROCKINGTON, G.; PIETROCOLA, M., Aplicações da robótica no ensino de física: análise de atividades numa perspectiva praxeológia. Revista de Educacion de las Ciencias. , v.14, p.32 - 36, 2013. ISSN 0124-5481, www.accefyn.org.co/rec.

SCHIVANI, M.; PIETROCOLA, M., The Contextualization in the Teaching Physics through 
of instruments of the Educational Robotics: analysis of activities by Verisimilar Praxeology. In: IVth international congress on the anthropological theory of didactics (ATD), Toulouse (France). Atas do 4CITAD, 2013.

, Robótica Educacional no Ensino de Física: Estudo preliminar sob uma perspectiva Praxeológica. In: XIV Encontro de Pesquisa em Ensino de Física - EPEF, Maresias - SP. Atas do XIV Encontro de Pesquisa em Ensino de Física, 2012.

SCHIVANI, M.; LUCIANO, P. G.; ROMERO, T. R. L.; ANDRADE, R., Novos materiais e tecnologias digitais no Ensino de Física. SÃO PAULO - SP : FTD, 2012, v.1. p.100. ISBN 9788532281180 .

SCHIVANI, M.; BORBA, G. L.; FELISARDO, J. M.; NETO, J. F.; PINHEIRO, G. D., As Ciências Espaciais e Astronáutica como Tema Gerador em Ensino de Física. In: XXIV Encontro de Físicos do Norte e Nordeste, 2006, João Pessoa - Paraíba. XXIV EFNNE Resumos, 2006. p. 32-32.

SENA DOS ANJOS, A. J., As Novas Tecnologias e o uso dos Recursos Telemáticos na Educação Científica: a simulação computacional na educação em física. Caderno Brasileiro de Ensino de Física, v. 25, n. 3, 2008.

SICILIANO, B.; KHATIB, O. (Eds)., Handbook of Robotics - Springer (Malestrom). Springer, pp. 1-1628, 2008. ISBN: 978-3-540-23957-4, e-ISBN: 978-3-540-30301-5.

SILVA, Erivanildo. L. da., Contextualização no ensino de química: idéias e proposições de um grupo de professores. Dissertação (Mestrado) - Universidade de São Paulo. Instituto de Química. Depto. Química Fundamental. São Paulo, 2007.

SILVA, João M. Vieira da., Robótica no ensino da física. Dissertação de Mestrado em Ensino da Física. Universidade do Minho, Portugal, 2008. Disponível em http://repositorium.sdum.uminho.pt/handle/1822/8069.

SILVA, R. B., Abordagem crítica de robótica educacional: Álvaro Vieira Pinto e Estudos de Ciência, Tecnologia e Sociedade. Dissertação (Mestrado em Tecnologia) - Programa de Pósgraduação em Tecnologia. Universidade Tecnológica Federal do Paraná. Curitiba, 2012.

SOUZA, Anderson R. de et al., A placa Arduino: uma opção de baixo custo para experiências de física assistidas pelo PC. Rev. Bras. Ensino Fís., São Paulo , v. 33, n. 1, Mar. 2011. http://dx.doi.org/10.1590/S1806-11172011000100026.

STEIN, D., Situated learning in adult education. ERIC Digest., n. 195, 1998. Disponível em: $<$ http://eric.ed.gov/?id=ED418250>. Acesso em 14 de maio de 2014.

SWIATKIEWICZ, O. Por que não uma abordagem praxeológica?! Análise Psicológica, 4(XV): 637-644, 1997.

TEIXEIRA, M. J. S.; SILVA, A. B. da., Organização praxeológica sobre área de figuras planas: uma breve abordagem do livro didático. In.: XI Encontro Nacional de Educação Matemática - XI ENEM. Curitiba, PR, 2013. 
TRIVELATO, S. L. F., Ciência/Tecnologia/Sociedade - mudanças curriculares e formação de professores. 1993. Tese (Doutorado em Educação) - Faculdade de Educação, Universidade de São Paulo, São Paulo, 1993.

UTGES, Graciela; FERNÁNDEZ, Patricia; JARDON, Alberto. Física y tecnología. Una integración posibleFísica y tecnología. Una integración posible. Caderno Brasileiro de Ensino de Física, [S.1.], v. 13, n. 2, p. 108-120, jan. 1996. ISSN 2175-7941. Disponível em: $<$ https://periodicos.ufsc.br/index.php/fisica/article/view/7052>. Acesso em: 21 Out. 2014. doi:http://dx.doi.org/10.5007/7052.

VALENTE, J. A.; MAZZONE, J. S.; BARANAUSKAS, M. C. C.,. Aprendizagem na era das tecnologias digitais. São Paulo: Cortez: FAPESP, 2007.

WARTHA, Edson J., SILVA, Erivanildo L. da, BEJARANO, Nelson R. R., Cotidiano e Contextualização no Ensino de Química. QUÍMICA NOVA NA ESCOLA. v. 35, n. 2, p. 8491, maio, 2013.

WANG, Eric L.; LaCOMBE, J.; ROGERS, C., Using LEGO® Bricks to Conduct Engineering Experiments. Proceedings of the American Society for Engineering Education Annual Conference \& Exposition, session 2756, 2004.

WELCH, Wayne W., Review of the research and evaluation program of harvard project physics. J. Res. Sci. Teach., 10: 365-378, 1973. doi: 10.1002/tea.3660100411.

ZANARDI, D. C., A análise praxeológica de atividades experimentais subsidiando a elaboração de situações-problema no ensino de física. 2013. Dissertação (Mestrado em Ensino de Física) - Universidade de São Paulo, São Paulo, 2013. Disponível em: $<$ http://www.teses.usp.br/teses/disponiveis/81/81131/tde-28042014-204753/>. Acesso em: 2014-08-24.

ZANARDI, Danilo C.; PEREIRA, Vanessa S.; KNEUBIL, Fabiana B., Organização praxeológica de saberes escolares: uma comparação da equação de clapeyron em livros de física e química. WCPE - The World Conference on Physics Education. WCPE 2012 Book of Abstracts, 2012.

ZANETTI, Humberto A. P., et al., Uso de robótica e jogos digitais como sistema de apoio ao aprendizado. Jornada de Atualização em Informática na Educação - JAIE, 2012.

ZANETIC, J., Física e arte: uma ponte entre duas culturas. Pro-Posições, v. 17, n. 1 (49) jan./abr., 2006.

, Física e Cultura. In. Ciência e Cultura, 2005.

ZYLBERSZTAJN, A., Resolução de problemas: uma perspectiva Kuhniana. In.: VI Encontro de Pesquisa em Ensino de Física. SBF/UFSC, Florianópolis, 26-20 outubro, 1998. 


\section{ANEXO 1}

Pré-teste aplicado antes de se iniciar a atividade "Empilhadeiras". 
Nome:

Data de nascimento:

1) Você já viu de perto uma empilhadeira parecida com a que é ilustrada ao lado? Se sim, onde e para o que era utilizada?

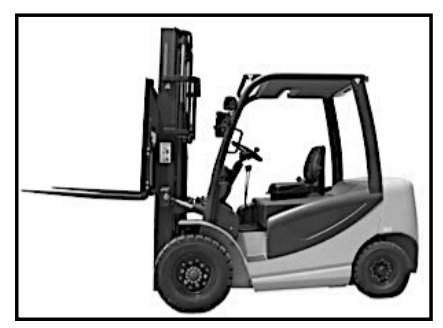

2) Cite 4 (quatro) lugares onde você acha que utilizam uma empilhadeira:

\begin{tabular}{|l|l|}
\hline 1. & 3. \\
\hline 2. & 4. \\
\hline
\end{tabular}
3) Você já brincou de gangorra?
( ) Sim.
( ) Não.
( ) Não lembro.

4) Duas crianças, com mesmo peso, sobem numa gangorra e seus pais seguram o banco até que elas estejam prontas para a brincadeira. Marque apenas com um $\mathbf{X}$, em qual (ou em quais) das situações ilustradas abaixo você acha que o Lado "A" da gangorra vai subir assim que os pais soltarem?

i. ( )
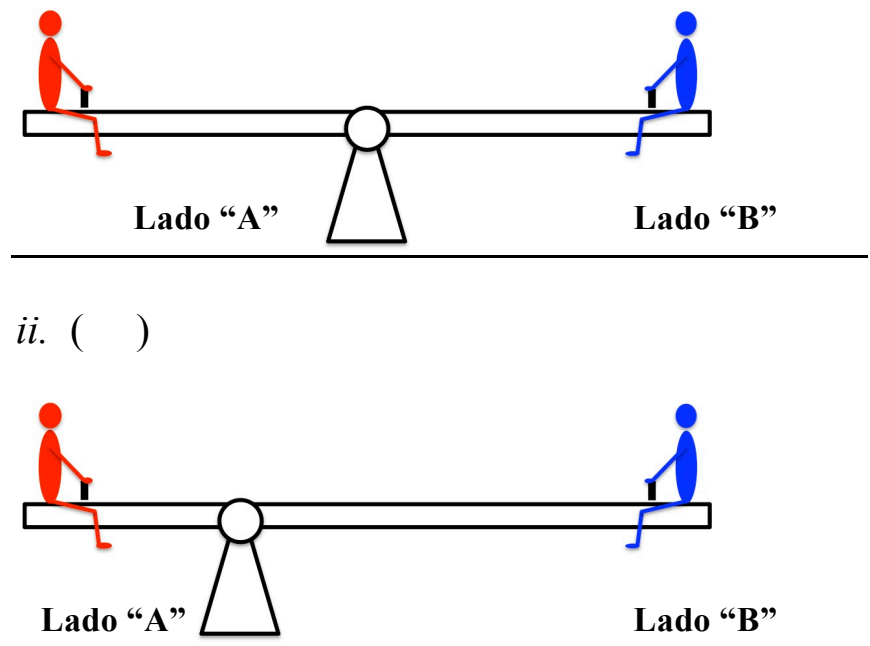

iii. ( )

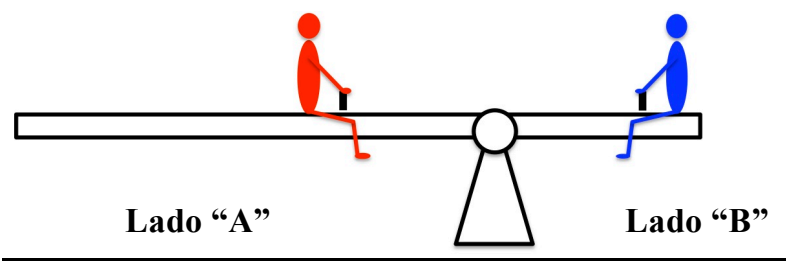

iv. ( )

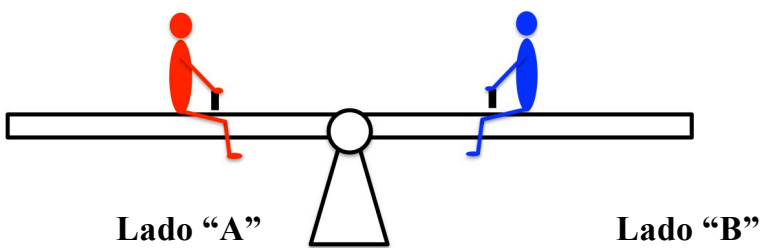




\section{ANEXO 2}

Pós-teste aplicado ao término da atividade "Empilhadeiras". 
Nome:

Data de nascimento:

1) A figura ao lado ilustra uma situação na qual uma pessoa quer soltar os parafusos da roda de seu carro, que está com o pneu furado. Entretanto, a força que ela aplica na chave não é suficiente para tirar o parafuso. Na sua opinião, o que essa pessoa poderia fazer para tirar os parafusos aplicando a mesma força? Justifique sua resposta.

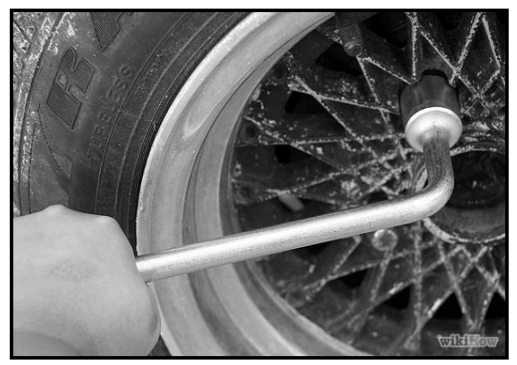

2) A utilização de carroças para transportar diferentes produtos ainda é uma prática comum, principalmente em regiões interioranas. Na sua opinião, o que poderia ser mudado na estrutura da carroça e configuração ilustrada abaixo para facilitar o transporte do barril pelo animal? Justifique.

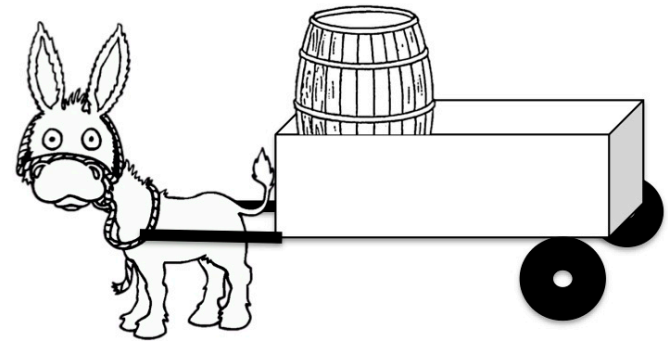

3) Duas crianças, com mesmo peso, sobem numa gangorra e seus pais seguram o banco até que elas estejam prontas para a brincadeira. Marque com um X, em qual (ou em quais) das situações ilustradas abaixo você acha que o Lado "B" da gangorra vai subir assim que os pais soltarem?
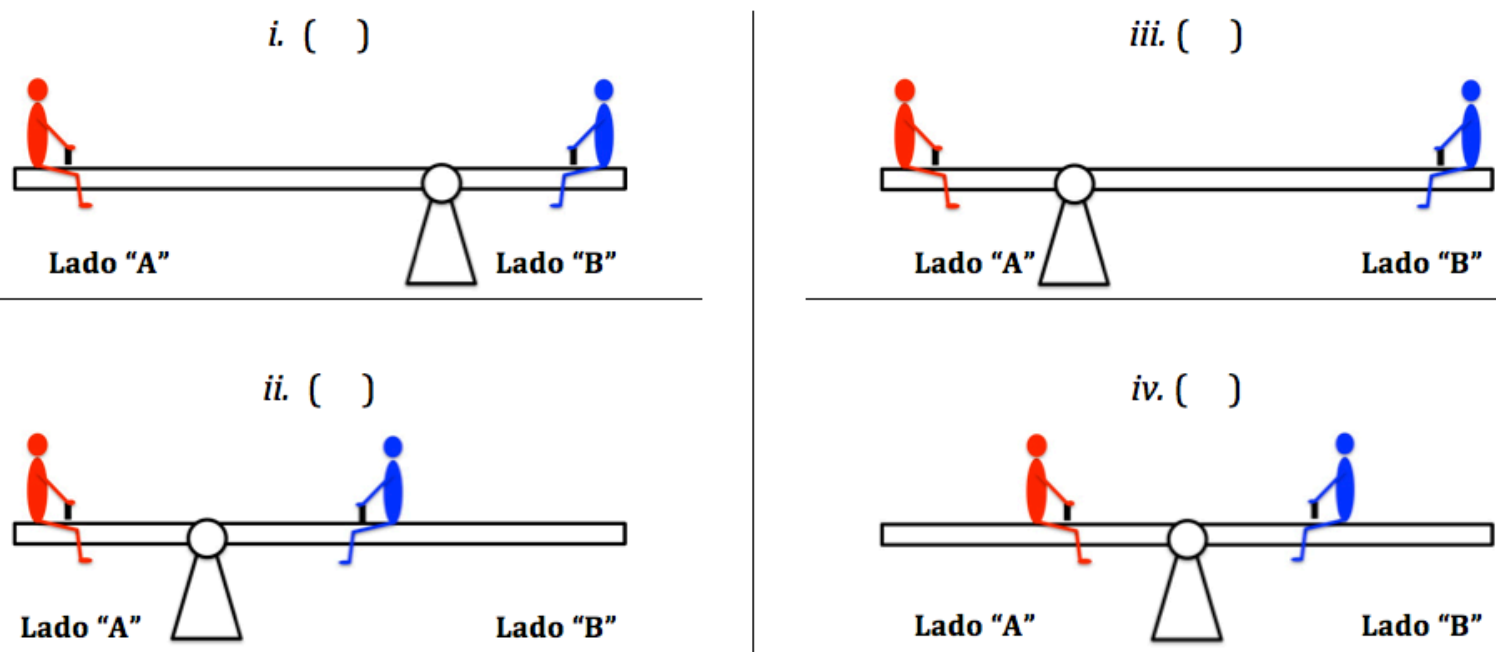


\section{ANEXO 3}

Pré-teste aplicado antes de se iniciar a atividade "Colisões". 
Turma: Nome:

Data de nascimento:

1) Você já presenciou uma situação de colisão entre dois carros ou motos?

( ) Sim. ( ) Não.

( ) Não lembro.

2) Você já sofreu algum acidente de trânsito?

( ) Sim.

( ) Não.

( ) Não lembro.

3) Você já brincou de jogar bolinhas de gude?

( ) Sim.

( ) Não.

( ) Não lembro.

4) Você já andou de patins?

( ) Sim.

( ) Não.

( ) Não lembro.

5) Você já brincou de carrinho bate-bate (figura abaixo, brinquedo comum nos parques de diversão)? ( ) Sim.

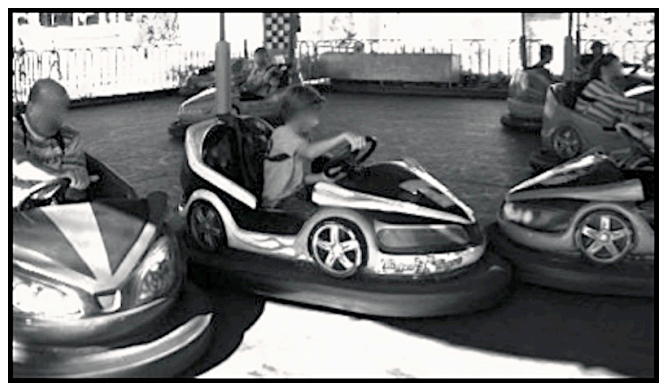

6) Cite 4 (quatro) principais grandezas físicas que na sua opinião atuam numa situação de colisão.

\begin{tabular}{|l|l|}
\hline 1. & 2. \\
\hline 3. & 4. \\
\hline
\end{tabular}

7) Para deter um navio superpetroleiro, suas máquinas são desligadas usualmente a uns $25 \mathrm{~km}$ do porto. Na sua opinião, por que é tão difícil parar ou fazer voltar um superpetroleiro?

8) Na sua opinião, o que pode fazer mais estrago num atropelamento: um ciclista durante uma corrida ou um caminhão sendo manobrado no pátio de uma empresa? Justifique sua resposta. 


\section{ANEXO 4}

Pós-teste aplicado ao término da atividade "Colisões". 
Turma:

Nome:

Data de nascimento:

1) Cite 4 (quatro) principais grandezas físicas que na sua opinião atuam numa situação de colisão.

\begin{tabular}{|l|l|}
\hline 1. & 2. \\
\hline 3. & 4. \\
\hline
\end{tabular}

2) Na sua opinião, a quem devemos atribuir maior quantidade de movimento: a um boi de uma tonelada em disparada ou a uma "bala" que sai pelo cano de um revolver? Justifique sua resposta.

3) Para deter um navio superpetroleiro, suas máquinas são desligadas usualmente a uns $25 \mathrm{~km}$ do porto. $\mathrm{Na}$ sua opinião, por que é tão difícil parar ou fazer voltar um superpetroleiro?

4) Conforme ilustrado abaixo, Pedro e seu carrinho de bate-bate (juntos possuem 50kg) colidem frontalmente a $2 \mathrm{~m} / \mathrm{s}$ no carro de João, ambos ficam com os veículos parados imediatamente após a colisão. Qual era a velocidade do veículo de João (juntos possuem 100kg) antes da colisão? Considere que não há perdas de energia, ou seja, sistema ideal. Marque abaixo a alternativa que você acha correta.

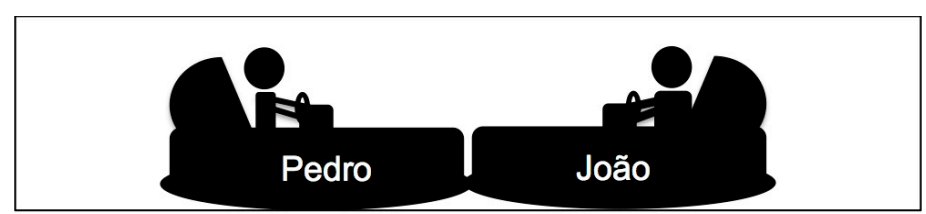
a) $3 \mathrm{~m} / \mathrm{s}$
b) $-2 \mathrm{~m} / \mathrm{s}$
c) $-1 \mathrm{~m} / \mathrm{s}$
d) $4 \mathrm{~m} /$ 

